\title{
3 Use of symbols
}

Symbols are found in manuscripts of - possibly - all cultures. Regarding Indic manuscripts, symbols are usually conspicuous features frequently found on the page and may be accurate representations or mere sketches of real objects taking on the appearance of abstract forms. Symbols may either serve as decorations and/or structuring devices, which sometimes signal the internal organisation of texts. At times, they may also have a particular religious or ritual significance, pertaining to specific faiths or schools of thought.

This chapter investigates the symbols found mainly in the manuscripts of my 'core' corpus referring to many more symbols from other manuscripts as well as some inscriptions. The aim is to discover whether certain symbols are characteristic of a particular region, epoch (largely within the time-frame $9^{\text {th }}$ to $13^{\text {th }}$ c.) etc. Thus, one cannot exclude the possibility that a specific workshop or group of scribes may have developed a specific way of drawing symbols, or that individual scribes may have developed their own style in the course of time.

\subsection{The term 'puṣpikā'}

Without further ado, however, a note should be devoted to the Sanskrit term puspikika. This literally means (among other things) 'little flower'. However, it is also commonly used in the Indian sub-continent, at least from the $19^{\text {th }} \mathrm{c}$. onward, to signify 'colophon', i.e. a short text providing information about the subject of a whole text or of one of its sections. ${ }^{130}$

In manuscripts containing a single text (STM) or more than one text, or multiple-text manuscripts (MTMs), the symbols are mainly embedded between double dand $\mathbf{s}^{131}$ placed either before or after a (sub-)chapter colophon or colophon; alternatively, they may appear both before and after these textual items. The

130 For the meaning of the term 'pușpikä', see Apte 1957, 1038 s.v. puṣpikā: "The last words of a chapter, which state the subject treated therein; e.g. iti śrimmahābhārate śatasāhasryām samihitāyām vanaparvani \&c. ... amuko 'dhyāyah ;" Tripāṭhī 1975, 41 states the following: "In many Indian languages the colophon is called puṣpikā. ... a colophon is often called 'iti śrī' because of its opening words. In Gujarati 'iti śri’' is also used in the general sense of 'en'”; Further, Das 2007, 37 understands the term 'pușpikā' as follows: "Most Orissan palm-leaf manuscripts have a pushpika (colophon) at the end, giving the name of the scribe and the date of copying ...”

131 It should be noted that there are also cases in which dandas are not used before and after the symbol see section 3.6.2.4.2 below where some of large symbols are delimited by a set of long vertical lines, but not sets of dandas. 
variety of shapes of the symbols ranges from that of a dot, a simple circle, and more complex symmetrical figures, and representations of stylised flowers, realistic flowers etc. The term puspikā is generally used to label all these various shapes, however, in this work I introduce the following distinctions: the term 'symbol' to indicate all symbols or signs as a whole, the expression 'stylised puṣpikâ' or 'florally stylised symbol' for symmetrical figures or symbols drawn in floral way, and 'realistic puspikā' for symbols more closely resembling real flowers containing stalks, leaves, sepals and buds etc. As certain symbols depict real or almost real flowers this is most likely why the term 'puṣpikä' has been taken for their label.

The term puspa, literally 'flower', is used in modern times among other things to refer to a book that has been published in a granthamālā ('garland of books'). ${ }^{132}$ In this respect, one may draw a speculative parallel between the use of the terms puṣpa and pusspikā and the size of the texts which they describe, i.e. a whole book, or a colophon or (sub-)chapter respectively.

\subsection{Use of symbols in manuscripts - Selected early examples}

If we try to find some of the oldest available evidence of the use of symbols by which texts or parts of texts have been divided/demarcated in Indic manuscripts, we may come across, the evidence offered by the Buddhist manuscripts from the Bāmiyān valley now part of the Schøyen Collection. ${ }^{133}$ The manuscripts of the collection are thought to date approximately from ca. $2^{\text {nd }}$ to $8^{\text {th }} c .^{134}$ the time period of which actually predates the one selected for this study.

Among the Schøyen manuscripts, a copy of an early commentary (MS 2373/1) written in 'Kuṣāṇa Brāhmī’ script ${ }^{135}$ presents a simple stylised puṣpikā. ${ }^{136}$

132 For example, in the book Samskṛtaracanāprakāsah which was published in a series by the Mahendra Sanskrit University, we find: śrīmahendrasaṃskṛtaviśvavidyālagranthamālāyāḥ pañcatrimśam pușpam. Literally meaning: 'The $35^{\text {th }}$ flower of the garland of books of the Mahendra Sanskrit University.'

133 I am aware of the existence of the ancient Gandhāran Buddhist scrolls, some of which are thought to be older specimens than the manuscripts of this collection and contain some symbols at the end of the chapters etc. (see e.g. Baums 2014, 202 and Fig. 2). Most of these scrolls are written in the so called 'Kharoșțī' script, in addition to the Brāhmī script. In the present study, I limit myself mainly to manuscripts written in the Brāhmī-related scripts or their northern, local derivatives.

134 See Braarvig et al. 2010, xvii.

135 See Sander 1968.

136 See IndoSkript, IS-Nr. 259. 
This object is purportedly dates from ca. $2^{\text {nd }} c .{ }^{137}$ In the last line one of the folio fragments (Plate XIII.1, $1 \mathrm{~A}$ ) one small stylised simple puṣpikā can be found after double danda. This symbol consists of circles with a few lines or elements between them (see Fig. 3.2-I).

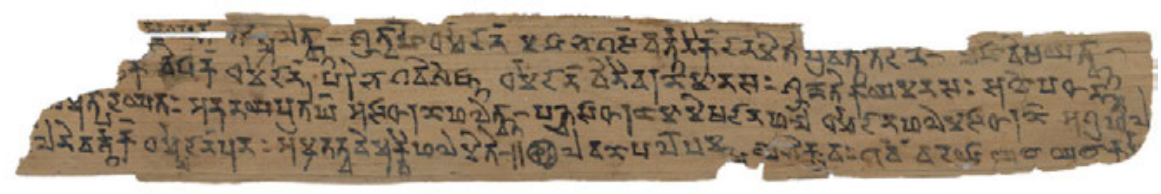

Fig. 3.2-I: An example of symbol in an earlier manuscript (reproduced by kind permission of editor from BMSC, 2002, Vol. II, Plate XIII.1, 1 A) @ Jens Braarvig

The symbol appears after the word 'iti' and is followed by 'lavanapalopamam ...':

/// lanivarttakaṃ dharmmadānaṃ punạ̣ amṛtatvavimuktīphalam iti . lavaṇapalopamam yo bhikṣavaḥ evaṃ vadeyā yathā yathā ka[rma] $]^{138}$

Another of the early examples of symbols used to divide texts in MTM is in the same collection in manuscript SC 2378. The manuscript is of Mahāyāna tradition and composed in 'Buddhist Hybrid Sanskrit' in the 'North Western Gupta' script ${ }^{139}$ and thought to date from ca. $5^{\text {th }} \mathrm{c}$. At the end of the Sūtra of the Śrimāalädevīsiṃhanādanirdeśa, ${ }^{140}$ there are two symbols on 392r (in line nos. 3 and 4) that enclose one of the colophons. Some portions of the first symbol (in line 3) have been partially lost, in particular in the centre, due to the damages to the leaf, so the shape of the symbol is not fully detectable. However, the second symbol (in line 4) is visible. Slightly bigger than the first one it has a circle encircling the inner part of the symbol. Both symbols fit into one text line of the folio. Examples of these symbols can be seen on the folio shown in Fig. 3.2-II.

137 See BMSC, 2002, Vol. II, 249.

138 Aside from the double danda and symbol, I present the transliteration of the textual part following the convention of BMSC, 2002, Vol. II, 250.

139 See Sander 1968, Tafel 9-20.

140 See BMSC, 2000, Vol. I, 63-218. 


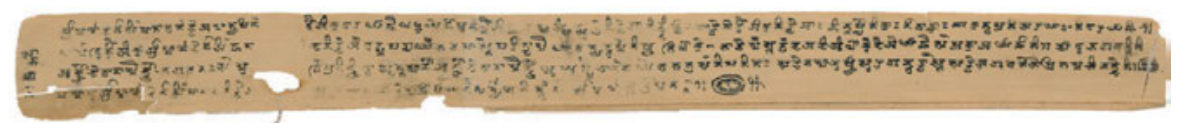

Fig. 3.2-II: Symbols at the end of the text (reproduced by kind permission of editor from BMSC, 2000, Vol. I, Plate III, fol. 392r) @ Jens Braarvig

E $3{ }^{141}$ [4] samāpta(ṃ) śrīmālādevīsiṃha[nāda]nirde[śa] O (sūtraṃ) [e](kayāna)ṃ

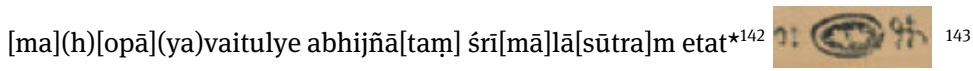

Enclosing colophons by means of symbols in MTMs, thus also demarcating the sections of a text, is a common feature of the manuscripts.

Another example of a beautifully drawn symbol is in one of the fragments written in the 'Gilgit/Bāmiyān Type I' script ${ }^{144}$ of the Vìtaśokāvadāna (MS 2380/6) ${ }^{145}$ on the legend of king Aśoka. This manuscript is thought to date from ca. $6^{\text {th }} \mathrm{c}$. The symbol appears after 'bhāṣața:' and is placed between double daṇdas (3 recto, MS 2380/6). It contains eight petals, encircled by another circle (see Fig. 3.2-III). A very similar symbol also containing eight petals can be found in some manuscripts of my corpus from Nepal (e.g. see Appendix I, SP 1 on 76b1, 96b1; $\mathrm{SP}_{2}$ on 95v6 below).

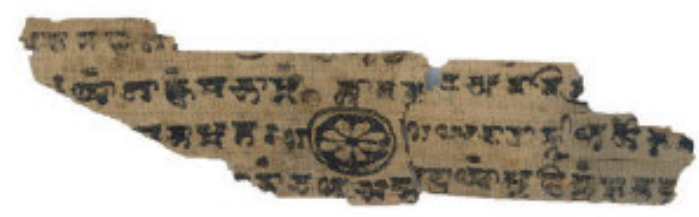

Fig. 3.2-III: Symbol (reproduced by kind permission of editor from BMSC, 2000, Vol. I, Plate VIII,1, fol. 3r) @ Jens Braarvig

141 See IndoSkript, Symbol: IS-Nr. 309.

142 Except for the symbols, here I present the transliteration of the textual part following the convention of BMSC, 2000, Vol. I, 67.

143 See IndoSkript, Symbol, IS-Nr: 309.

144 On the script, see Sander 1968.

145 See BMSC, 2000, Vol. I, 219-231. 


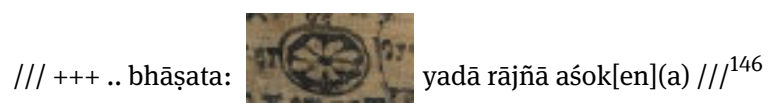

An example of a symbol with 'double circles' can be found in the birch-bark manuscript MS 2385 on 26r1. ${ }^{147}$ The editors of the text report there to be two texts within the manuscript, i.e. the Bhaișajyagurusūtra and the Vajracchedika Prajñāpāramitā Sütra. ${ }^{148}$ The Bhaișajyagurusūtra ends with its 'sub-colophon' on folio $26 \mathrm{r} 1$ and, at the end of the sub-colophon, double circles are placed between double dandas (see also section 3.4, type no. 6 below). After that the Vajracchedikā Prajñāpāramitā Sütra begins with the invocation 'namo śäkyamuna ...'. This symbol can be seen in Fig. 3.2-IV.

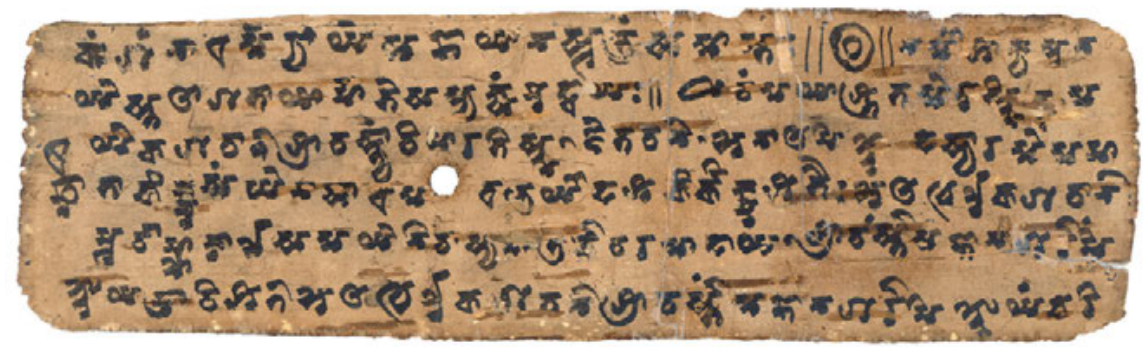

Fig. 3.2-IV: Symbol at the end of a particular text (reproduced by kind permission of editor from BMSC, 2016, Vol. III, Plate VII, fol. 26r) @ Jens Braarvig

... nā<ma> dharma<pa>ryāyaṃ mahāyānasūtram samāptạ $\|[0] \mid]^{149}$ namo śākyamuna $^{150}$

To conclude, evidence from the earlier manuscripts from Gilgit show that drawing different kinds of symbols at the end of chapters and texts with colophon or colophon-like statements predates the time-frame of $9^{\text {th }}$ to $13^{\text {th }}$ c. selected for my study.

146 Apart from using the symbol, I follow the transliteration of the textual part of BMSC, 2000, Vol. I, 222.

147 See BMSC, 2006, Vol. III, Plate VII. 1.

148 See BMSC, 2006, Vol. III, 89-132.

149 For examples of double circles, see below section 3.4, type no. 6 .

150 Aside from the symbols and the omission of some parts of the text, I follow the transliteration of the textual part as BMSC, 2006, Vol. III, 95. 


\subsection{Shape and size}

The symbols have different shapes even within the same manuscript. Some can have a simple shape, whereas others may have been drawn so skillfully they appear and could well be the work of a professional artist. Size can also vary greatly, even within the same manuscript. They may occupy the whole height of the folio (top to bottom) or just one line of the text on the folio. At times, they are drawn so small they are difficult to find on the folio.

Such variation in shape or size may also correspond to the differing degrees of emphasis given to the various levels of a text. Symbols appearing at the end of a chapter may be (slightly) bigger than those within a chapter, possibly hinting at a change in topic. Symbols placed almost at the end or actually at the end of a text accompanied by a colophon or other statements, are drawn more elegantly or larger than those at the end of a chapter or within the text (see section 3.6.2.4.1 below). A particular type of sequence or distribution of symbols may also be related to a specific tradition (see section 3.6.2.4.2 below).

Although changes in size and shape and the level of refinement of the symbols can be closely related to scribal habits (if the symbols are drawn by the scribes who copied the texts), such variations may at times provide specific information to the reader on the particular part of the text he/she is reading at that moment, should it be a chapter of the text or the end of the whole text (see sections 3.6.2.4.1 and 3.6.2.4.2 below).

In terms of the shape of the symbols and their production, it is fair to assume that in only in a few cases have the symbols been drawn with the help of tools, such as compasses, rulers, etc. At other times, particularly when a certain degree of accuracy is lacking, the symbols have been drawn freehand. To improve our understanding of the production of symbols, a specific example was examined during a field trip to Nepal (see section 5.2 for details below).

\subsection{Types of symbols found in the same region or in more than one region}

In this section I investigate the distribution of types of symbols. They can be found in various manuscripts originating from one particular area, or in several manuscripts across different areas or in manuscripts from different periods of time. Manuscripts belonging to the same religious tradition or containing texts of the same literary genre may also contain specific varieties of symbols.

In the following figures, I present some types of 'identical' or 'almost identical' symbols from manuscripts originating from the same area and from all the areas 
investigated in my study. As Indic manuscript culture is so rich in literature and production of artefacts, I am certainly not claiming to show all examples from all available manuscripts of particular areas or time periods here. In this section I present but a few selected symbols in the hope these examples will stimulate new ideas for future studies. I have selected mainly one symbol for each manuscript and arranged them in possible chronological order (see Figs. 3.4-I to 3.4-XLVII).

(1) These types of similar symbols can be seen in the following Figure. Here the symbol looks like a kind of 'dot'. ${ }^{151}$ Please note that in manuscripts written in Śāradā script (from Kashmir) a dot or a dot-like element generally corresponds to ' 0 '. ${ }^{152}$ Examples of this type can be seen in Fig. 3.4-I.

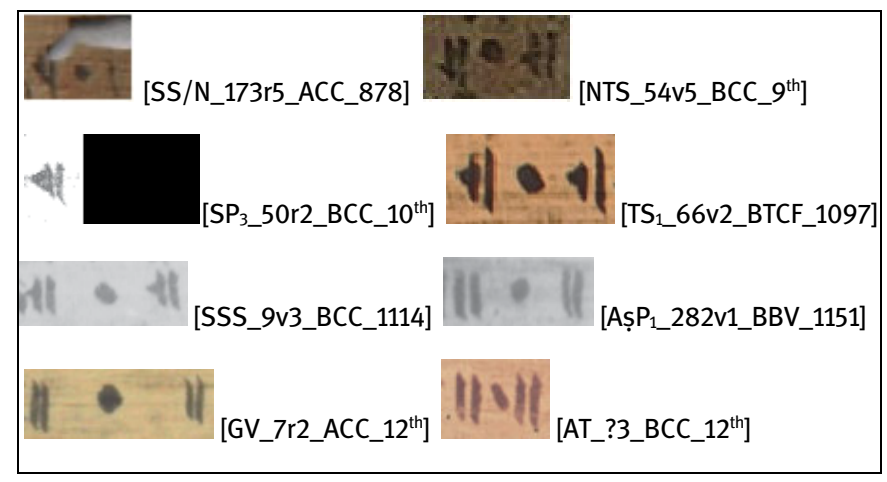

Fig. 3.4-I: Similar symbols

(2) One of the most popular types of the symbol is the simple circle, ${ }^{153}$ often found in manuscripts before and/or after chapter colophons, colophons, in the parts of the

151 A similar dot can be found in the manuscript of the Sivadharma corpus (ca. 12 ${ }^{\text {th }}$ c.) (CUL Add.2102) on 278r3_ACC.

152 For example, see Grierson 1916, 698 the numerals for '10', '20', ‘30', '100', '1000'; Slaje 1993, 46 the numerals for ' 0 ' and ' 10 '.

153 Simple circles can be found in the Vilavațti Grant of Pallava Siṃhavarman (446 CE), EI 24, IndoSkript, symbol, IS-Nr: 24; in the Badal pillar inscription of the time of Nārāyaṇapāla (860917 CE), EI 2, No. 10, 160-167, Einicke 2009, 51, 284, 343 as NagIs3(860+)_1; in the manuscript of the Saurasaṃhitā (NS 69 / 949 CE) (NAK 1/1231 / NGMPP A 1161/6), Bang 2017, 30, Table I.4 (one circle as example); in the Kharepatan plates of Rattaraja (ŚS 930 / 1008 CE), EI 3, No. 40, 292-302, Mirashi 1977, CII 6, No. 41, 183-193, Einicke 2009, 55, 284, 343 as NagIs(1008)_2; in the manuscript of the Kulālikāmnāyatantra (NS 158 / 1037 CE) (NAK 5/877 / NGMPP A 41/3), Bang 2017, 30, Table I.4 (one circle as example); in the manuscript of the Niśvāsamahātan- 
post colophonic statements etc. ${ }^{154}$ In addition a circle or circle-like feature corresponds sometimes to the letter 'thh $a^{155}$ or letter-numerals ' 0 '. ${ }^{156}$ Examples of the type of symbols can be seen in Fig. 3.4-II.

trāntargatapratișthātantra (NS 180 / 1060 CE) (NAK 1/279 / NGMPP A 41/15-A 42/1), Bang 2017, 30, Table I.4 (one circle as example); in the manuscript of the Svacchandalalita (NS 188 / 1068 CE) (NAK 1/224 / NGMPP B 28/18), Bang 2017, 30, Table I.4 (one circle as example); in the manuscript of the Siddhāntasārapaddhati (NS 197 / 1077 CE) (NAK 1/1363 / NGMPP B 28/29), Bang 2017, 30, Table I.4 (one circle as example); in the manuscript of the Kubjikāmata (NS 212 / 1092 CE) (NAK 1/1077 / NGMPP B 25/24), Bang 2017, 30, Table I.4 (one circle as example); in the manuscript of the Siddhāntasārapaddhati (NS 231 / 1111 CE) (NAK 5/743 / NGMPP B 28/19), Bang 2017, 30, Table I.4 (one circle as example); in the manuscript of the Amarakoșațika (NS 239 / 1119 CE) (KL 560 / NGMPP C 121/1, Pant 2000, Einicke 2009, 150, 152, 154-155, 286, 344 as New10.1(1119)_11, New10.2(1119)_6, New10.3(1119)_1, New10.4(1119)_3; in the Copper Plate of the Vañapalli Grant of Sauryāditya (1020 CE), Sircar 1963-1964, IndoSkript, symbol, IS-Nr: 192; in the manuscript of the Pañcarātramahājñ̄anna (NS 147 / 1027 CE) (NAK 1/1648 / NGMPP A 54/9), Einicke 2009, 143, 286, 344 as New4(1027)_1; in the Naḍagām Plates of Vajrahasta (ŚS 979 / 1058 CE), EI 4, IndoSkript, symbol, IS-Nr: 457; in the Copper-Plate of the time of Ānandadeva (NS 282 / 1161 CE), Pant/Sharma 1977, IndoSkript, symbol, IS-Nr: 752; in the manuscript of the Śivadharmaśāstra (NS 290 / 1170 CE) (NAK 1/1075 / NGMPP B 7/3), see Einicke 2009, 158, 286, 344 as New11(1170)_4. See also Sākya 1973, 85 the first symbol in the first row; Sarkar/Pande 1999, Fig. 15; 2-5.

154 See Bühler 1896, 85: "In späterer Zeit kommen gleichfalls bisweilen im Texte, nach grösseren Abschnitten und öfter am Ende von Documenten, Symbole vor, die meist sehr abgeschliffene Formen haben. Das gewöhnlichste besteht aus einem grossen Kreise mit einem kleineren, oder auch mit mehreren Puncten in der Mitte. Dieses kann entweder aus dem Dharmacakra entstanden sein, der sich noch vor CII, 3. Nr. 63, deutlich findet, oder aus dem Lotus, der auch vorkommt. Da der Kreis mit einem Puncte $\odot$ dem alten tha entspricht, so werden andere, späteren tha ähnliche, oder gleiche Zeichen dafür gebraucht ...”; see Sarkar/Pande 1999, 55 with regard to the interpretation and meaning of circle, circle with dot or 'double circles' in inscription: "The majority of the highly abstract figures of the inscriptions share one common feature: a circle or a circle with a dot in the centre. As indicated, the circle possibly represents the thalamus on which other floral members stand and survive. It serves as a platform for the pollen-bearing stamen and the female-organ bearing carpel to unite. So, a circle with a dot or concentric circles represent union, procreation, proliferation and prosperity."

155 For the letter 'tha', see Bühler 1896, Tafel II, row 19, Tafel III, row 17, Tafel IV, row 18 and Tafel V, row 21; Dani 1963, plate IIIa, Iva, Va, Via, VIIIa, IXa, Xia, XIIa, XIVa, XVIIa; Sander 1968, Tafel 1, 9, 21.

156 For the figure-numerals '0', see Bendall 1883, Table of Figure-numerals; Bühler 1896, Tafel IX. 


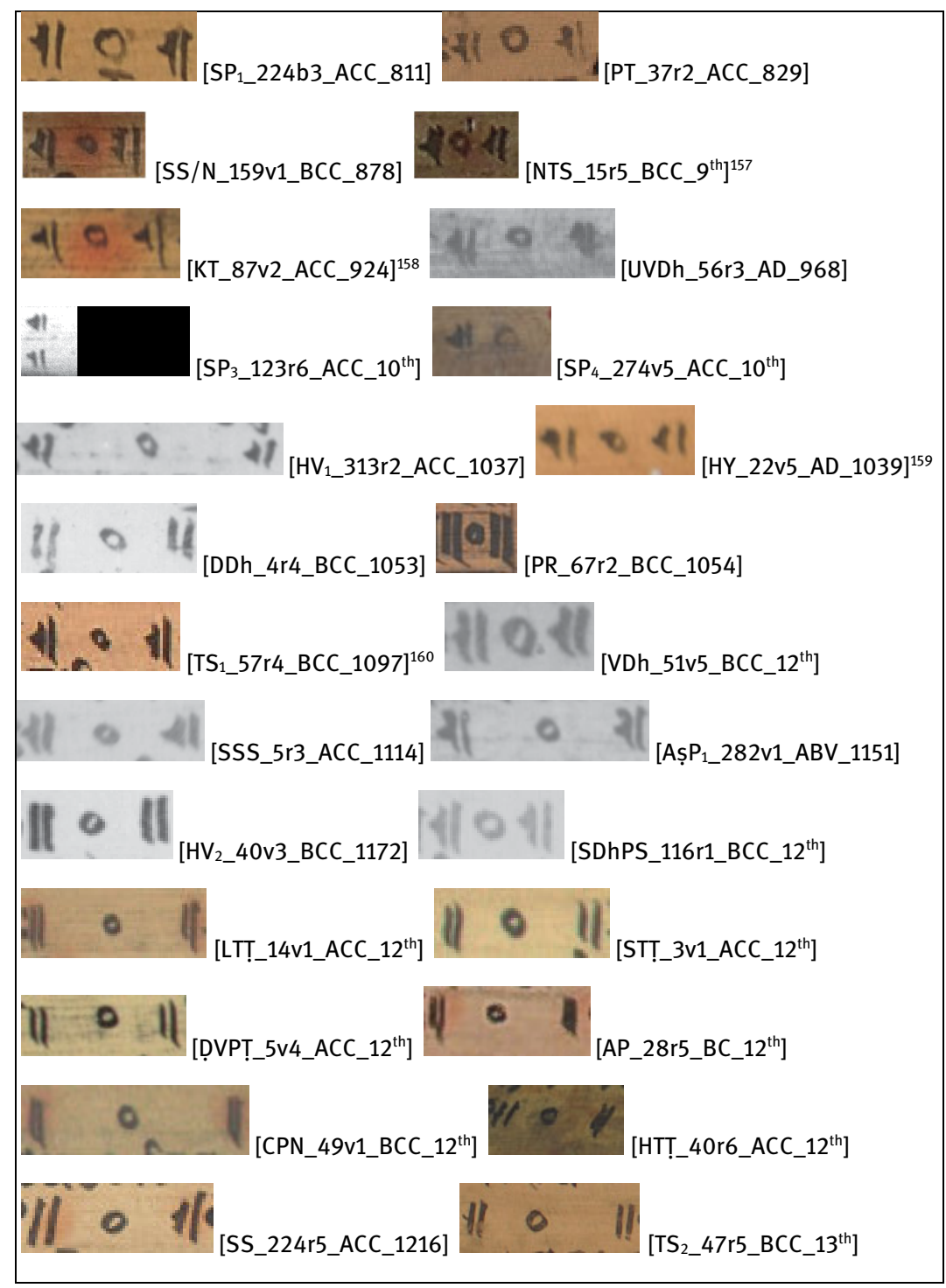

Fig. 3.4-II: Similar symbols

157 One circle of this manuscript has also been used by Bang 2017, 30 in Table I.4.

158 One circle of this manuscript has also been used by Bang 2017, 30 in Table I.4

159 The same circle has also been used by Bang 2017, 30 in Table I.4.

160 One circle of this manuscript has also been used by Bang 2017, 30 in Table I.4. 
(3) Another type includes a symbol which looks like a 'figure-eight knot', or two small circles joined together 'horizontally'. It appears before and/or after chapter colophon etc. ${ }^{161}$ In addition a 'figure-eight knot' also has some similarities to the (lower) part of the letters ' $i$ ' or ' $c h a$ '. ${ }^{162}$ Regarding manuscripts containing Buddhist texts such as $\mathrm{Asp}_{1}, \mathrm{SDhPS}$, one may also interpret this symbol as a representation of one of the popular Buddhist symbols śrivvatsa ('endless knot'). Examples can be seen in Fig. 3.4-III.

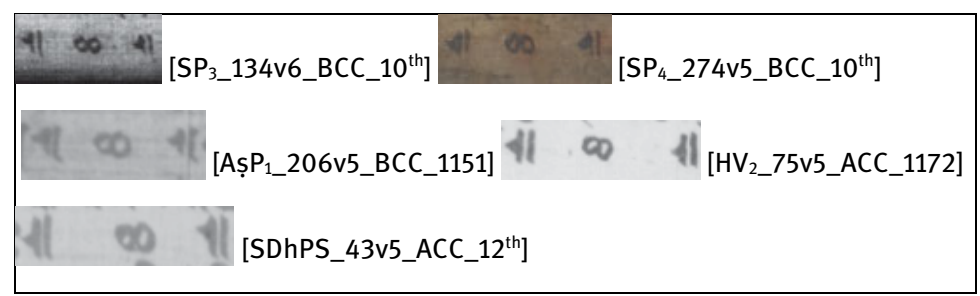

Fig. 3.4-III: Similar symbols

(4) The next type of symbol includes a nearly circle-like element embedding a slightly curved vertical-like line at its centre. ${ }^{163}$ This symbol can be found before and/or after chapter colophons, after a particular smaller section etc. in manuscripts. ${ }^{164}$ Examples of symbols can be seen in Fig. 3.4-IV.

161 A very similar symbol used as a sign to indicate the unwrittenable space on the folio can be found in the (birch-bark) manuscript of the Atharvaveda (1419 CE) (Universitätsbibliothek Tübingen) written in Śaradā script, see Einicke 2009, 171, 294 as Sar2(1419)_2.

162 For letters ' $i$ ' and 'cha' see Bendall 1883, Table of Letters; Bühler 1896, Tafel III, row 12, Tafel IV, row 13, Tafel V, row 16, Tafel VI, rows 3 and 21, Tafel VII, row 14.

163 This type of symbol resembles some versions of the letter-numerals ' 80 '. For examples, see Bühler 1896, Tafel IX.

164 Similar symbols can be found in the Bhadana grant of Aparajita (ŚS 919 / 997 CE), EI 3, No. 37, Einicke 2009, 54, 284 as NagIs9(997)_1; in the manuscript of the Viṣnudharmaśāstra (NS 167 / 1047 CE) (NAK 1/1002/1 / NGMPP A 1080/3), Grünendahl 1983, 14 as Ms. N6, Einicke 2009, 144, 286 as New5(1046)_1. See also Saàkya 1973, 85 the first symbol in the last row. 


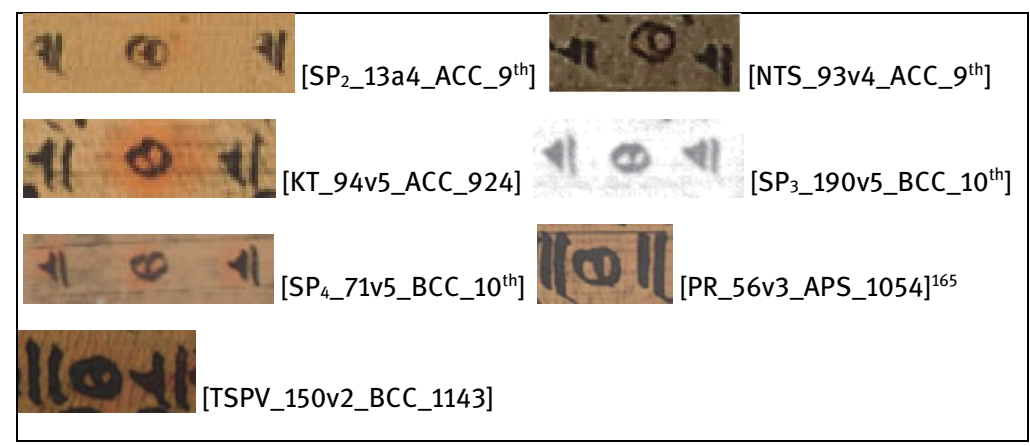

Fig. 3.4-IV: Similar symbols

(5) Very similar to the aforementioned type of symbol, is a curved vertical-like line that runs down passing through the lower part. The symbol appears to have a 'tail'. ${ }^{166}$ The tail often continues downward and to the right. To some extent, the symbol resembles certain versions of the letter-numerals for ' 80 ' ${ }^{167}$ This symbol may also be interpreted as a representation of sprouting seeds.

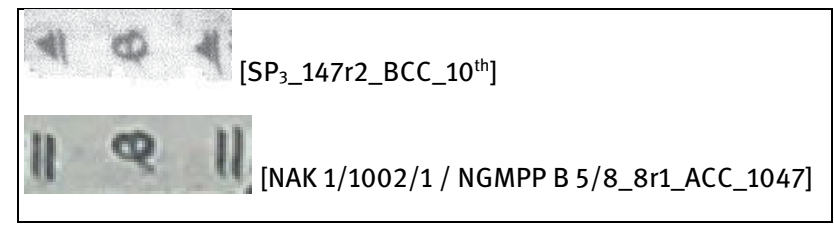

165 This appears after a particular verse line.

166 A similar symbol can be found in the manuscript of the Viṣnudharma (NS 210 / 1090 CE) (NAK 1/1002/2 / NGMPP B 5/7), Grünendahl 1983, part 1, 10 as Ms. N3, Einicke 2009, 146, 286 as New8(1090)_6; in the manuscript of the Sarvaprakarana (NS 277 / 1157 CE) (KL 36 / NGMPP C 4/2) on 5r4_ACC, 6r2_BCC, 8v3_ACC, 9r3_ACC, 14v1_ACC, 14v6_BCC, 16v4_BCC, 17v4_ACC, 18v5_BCC, 19v6_ACC, 20r2_ACC, 20r4_ACC, 20v2_BCC, 20v5_BCC, 23v3_ACC, 24r_ACC, 26r3_ACC; in the manuscript of the Pingalāmata (NS 294 / 1174) (NAK 3/376 / NGMPP A 42/2), Bang 2017, 30, Table I.4; in the manuscript of the Viṣnudharma (NS 281 / 1161 CE) (NAK 4/1389 / NGMPP A 10/3) on 124v1_BCC, Grünendahl 1983, part 1, 12-13 as Ms. 5.

167 For the letter-numerals ' 80 ', see Bendall 1883, appendix, Letter-numerals, rows 3, 4 and 8; Bühler 1896, Tafel IX. 


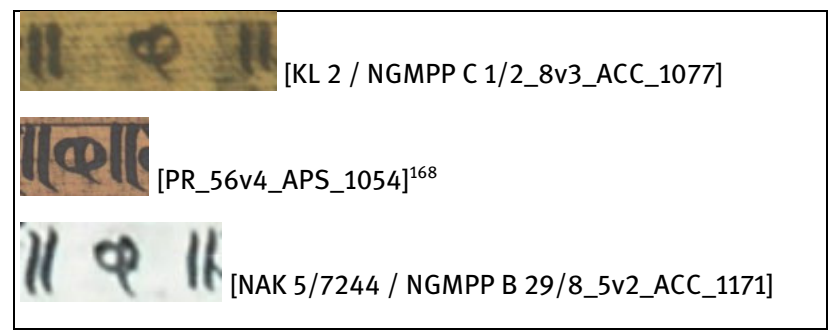

Fig. 3.4-V: Similar symbols

(6) A further type contains a symbol consisting of 'double circles'. This symbol can be found in many manuscripts. ${ }^{169}$ Examples of symbols can be seen in Fig. 3.4-VI.

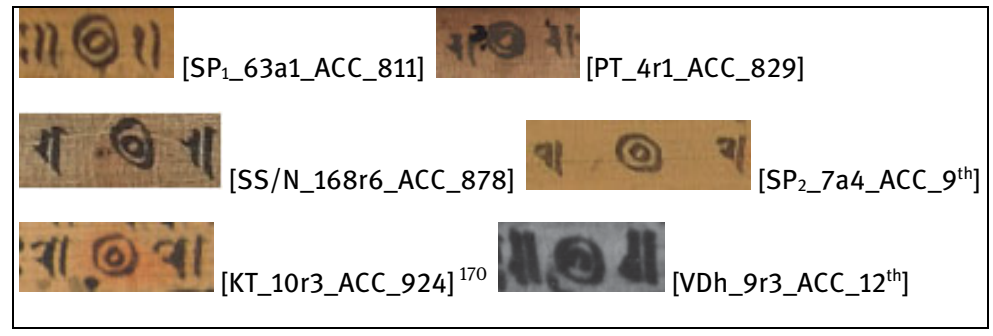

Fig. 3.4-VI: Similar symbols

168 Actually this appears after a particular verse line.

169 Examples of 'double circles' can be found in the Fragmentary Copper-Plate from Arakan (496-520), EI 37, IndoSkript, symbol, IS-Nr: 87; in the manuscript of the Jātakamālä (ca. 500-750 CE), IndoSkript, symbol, IS-Nr: 323; in the Kanasva Stone Inscription of Sivagana (738 CE), IndoSkript, symbol, IS-Nr: 318; in the manuscript of the Sarvajñānottara (ca. $9^{\text {th }}$ c.) (NAK 1/1692 / A 43/12), Bang 2017, 30, Table I.4 (one double circle); in the manuscript of the Bhairavamangala (ca. $10^{\text {th }} / 11^{\text {th }}$ c.) (NAK 5/687 / NGMPP B 27/21), Bang 2017, 30, Table I.4 (one double circle); in the copper plate of the Vañapalli Grant of Sauryāditya (1020 CE), EI 35, 130-136, IndoSkript, symbol, IS-Nr: 192; in the manuscript of the Sivadharmaśāstra (NS 192 / 1072 CE) (NGMPP E 2787/11), IndoSkript, symbol, IS-Nr: 181; in the manuscript of the Svacchandalalitabhairavatantra ${\text { (ca. } 11^{\text {th }}}^{\text {the }}$ c.) (KL 68 / NGMPP C 6/5), Bang 2017, 30, Table I.4 (one double circle); see also Sarkar/Pande 1999, Fig. 15, 1 and 8.

170 One double circle of this manuscript has also been used by Bang 2017, 30 in Table I.4. 
(7) Another type includes a simple symbol containing a circle at its centre surrounded by four almost semi-circular petals. ${ }^{171}$ This symbol can be found before and/or after the chapter colophons, with the foliation etc. Regarding the symbol with foliation, it should be noted that the symbol contains only three semicircular petals, the upper petal has most probably been replaced by the foliation number. The examples of symbol can be seen in Fig. 3.4-VII.

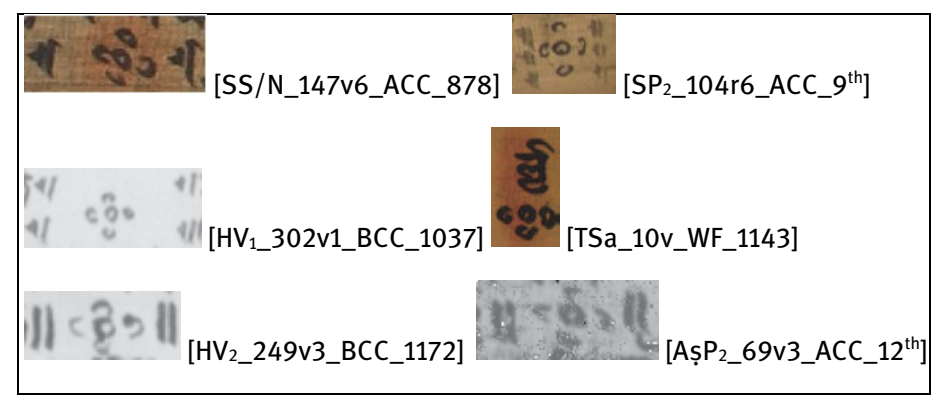

Fig. 3.4-VII: Similar symbols

(8) A stylised simple puṣpikā comprised of a circle surrounded by four almost semi-circular petals and four lines features frequently. ${ }^{172}$ The symbol appears before and/or after chapter colophons or in other places with foliation, around string-holes etc. in manuscripts. Please note that in the symbol around the stringhole on the folio the hole replaces the circle. Examples can be seen in Fig. 3.4-VIII.

171 For example, similar symbols can be seen in the Bendigānahalḷi Plates of VijayaKṛṣnavarman (ca. 400-450), IndoSkript, symbol, IS-Nr: 410; in the manuscript of the Śivadharma corpus (ca. 12 ${ }^{\text {th }}$ c.) (CUL Add.1694.1) on 5r5_ACC, 27r2_BCC, 27v4_ACC, 34r4_B/ACC, 123v_B/ACC. 172 Similar symbols can be seen, for instance, in the manuscript of the Niśvāsamahātantrāntargatapratișthātantra (NS 180 / 1060 CE) (NAK 1/279 / NGMPP A 41/15-A 42/1), Bang 2017, 30, Table I.4 (one symbol has been given); in the manuscript of the Kubjikāmata (NS 212 / 1092 CE) (NAK 1/1077 / NGMPP B 25/24), Bang 2017, 30, Table I.4 (one symbol has been presented); in the manuscript of the Matasāra (NS 317 / 1197 CE) (KL 70 / C 6/7), Bang 2017, 30, Table I.4 (one symbol has been presented); in the manuscript of the Śivadharma corpus (ca. $12^{\text {th }}$ c.) (CUL Add.1694.1) on 118v6_B/ACC. See also Śākya 1973, 85 the second symbol in the first row. 


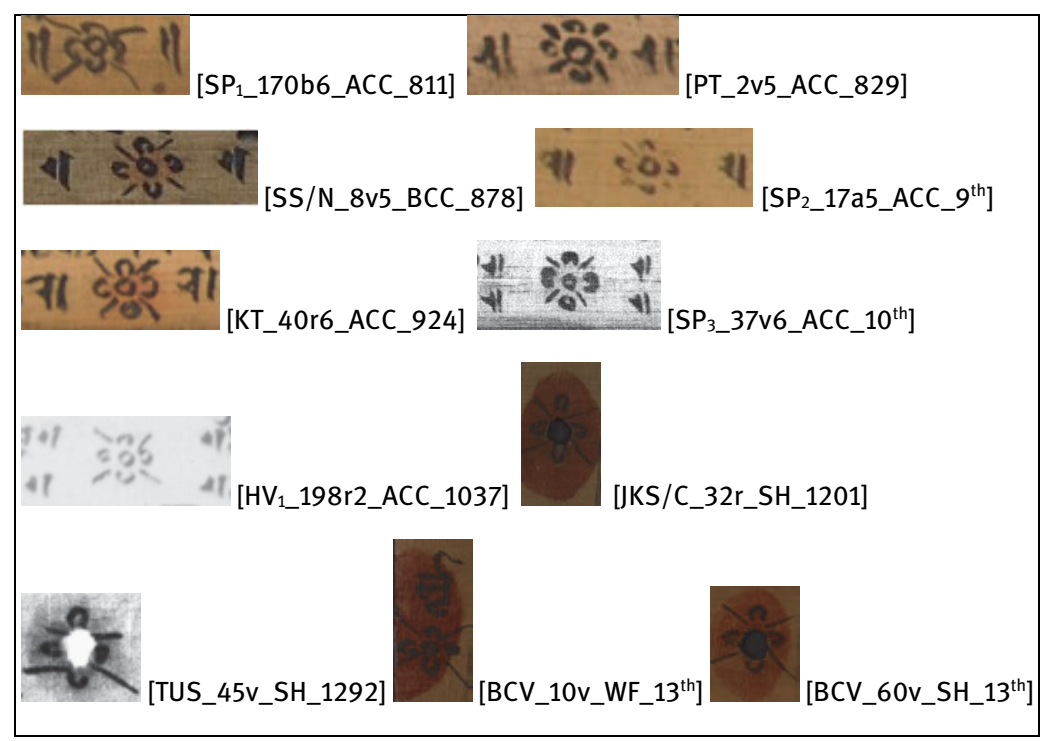

Fig. 3.4-VIII: Similar symbols

(9) Rather similar to the aforementioned type, but with a small 'line' or 'stroke' added to the outer side of four petals can also be found. ${ }^{173}$ Examples can be seen in Fig. 3.4-IX.

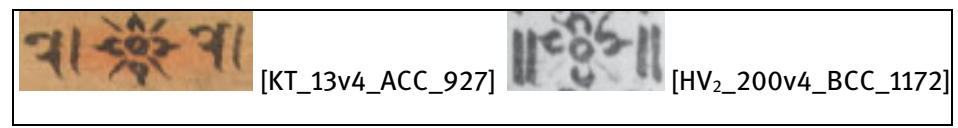

Fig. 3.4-IX: Similar symbols

173 Quite similar symbols can be found in the manuscript of the Brahmayāmala (NS 172 / 1052 CE) (NAK 3/370 / NGMPP A 42/6), Bang 2017, 30, Table I.4 (one symbol has been presented); in the manuscript of the Svacchandalalitabhairavatantra (ca. 11 ${ }^{\text {th }}$ c.) (KL 68 / NGMPP C 6/5) on 21r3_ACC, 61v1_ACC, 80r2_ACC, 178r1_BCC, 186v5_BCC, 189r5_BCC, 191r2_ACC; in the manuscripts of the Viṣnudharma (ca. 12 ${ }^{\text {th }}$ c.) (KL 578 / NGMPP C 54/5), Grünendahl 1984, part 3, 6-7 as Ms. N14 on 12v3_ACC, 20r1_ACC, 21v2_ACC, 30r4_ACC, 39v5_ACC, 76v4_ACC, 181r3_BCC, 184r1-2_B/ACC, 199r3_BCC, 202r3_BCC. 
(10) Another type includes a stylised pusspika similar to the previous one (see Fig. 3.4-VIII), in which, however, the semi-circular petals are facing outside. ${ }^{174}$ This symbol can be found before and/or after chapter colophons, around stringholes (here with the hole replacing the circle), with foliation etc. (see Fig. 3.4-X below).

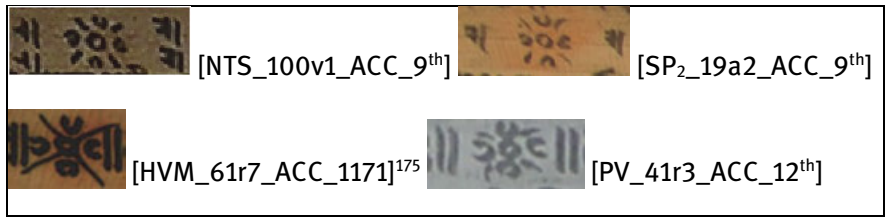

Fig. 3.4-X: Similar symbols

(11) The next type comprises a stylised pușpikā containing a circle in the centre sorrounded by five thickly drawn petals. Examples of these can be seen in Fig. 3.4-XI.

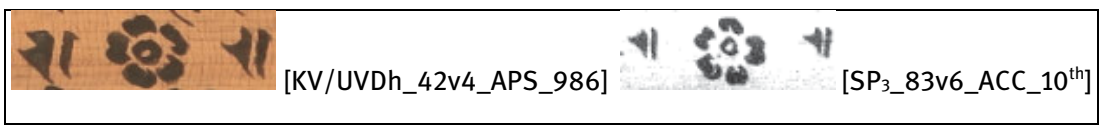

Fig. 3.4-XI: Similar symbols

(12) It is possible to find a stylised puspiki $\bar{a}$ containing a circle surrounded by four petals, each obtained by combining two almost semi-circular petals. This symbol appears before and/or after chapter colophon or around the string-hole

174 Identical symbols can be found in the Parvatiya Plates of Varnamalavarmadeva (825-875 CE), EI 92, IndoSkript, symbol, IS-Nr: 771; in the Hāoraghāț Plates of Balavarman III of Kāmarūpa (ca. 885-910 CE), EI 3, IndoSkript, symbol, IS-Nr: 159; in the Copper-Plate Grant of Kadamba Tribhuvanamalla (1107 CE), EI 30, IndoSkript, symbol, IS-Nr: 86; in the manuscript of the Sārāvalī (NS 288 / 1168 CE) (NAK 5/700 / NGMPP A 31/10) on 63v6_ACC, 117r5_ACC, 122v3_ACC, 139v2_A/BPC. See also Śākya 1973, 85 the first symbol in the fourth row from the top; Sarkar/Pande 1999, Fig. 12,1.

175 Similar symbols (without circle in the centre) appear around string-holes on nearly all folios (with a few exceptions), see section 3.5.3, Fig. 3.5.3-III below. Here the circle has been replaced by the string-hole. Additionally, a similar symbol can be found with the foliation number ' 80 '. 
(with the hole replacing the circle) etc. in manuscripts. ${ }^{176}$ Examples can be found in Fig. 3.4-XII.

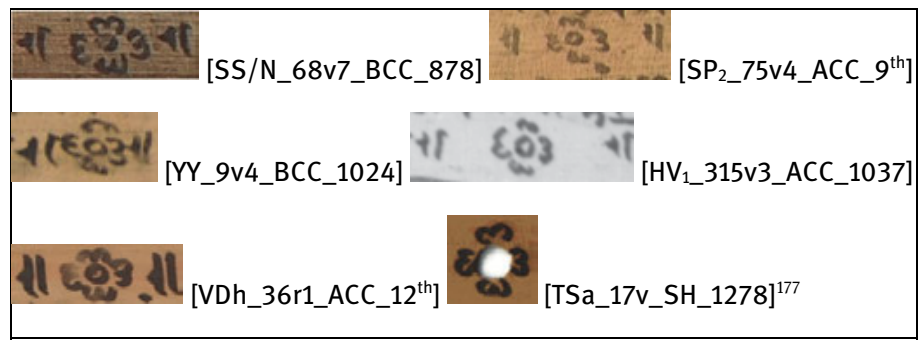

Fig. 3.4-XII: Similar symbols

(13) Another type of symbol similar to the type in no. 12, but with petals facing outward is found in manuscripts. Examples can be seen in Fig. 3.4-XIII.

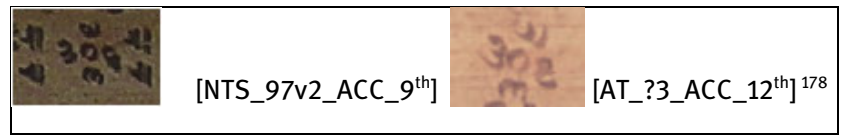

Fig. 3.4-XIII: Similar symbols

(14) The next type of stylised puspikā is one containing a circle in the centre surrounded by four lines and four petals - with the petals made by joining two semi-circles. ${ }^{179}$ Examples can be seen in Fig. 3.4-XIV.

176 Similar symbols appear in the manuscript of the Amarakoșațika (NS 239 / 1119 CE) (KL 560 / NGMPP C 121/1), Pant 2000, part I, 79; part II, 54, 56, IndoSkript, symbol, IS-Nr: 678.

177 This symbol appears around the string-hole on the folio and the circle is replaced by the string-hole. See also section 3.6.1, Fig. 3.6.1-I for details.

178 Regarding the specific meaning of this symbol, see section 3.6.2.1.2 and Fig. 3.6.2.1.2-II below.

179 Similar symbols appear in the manuscript of the Bhairavamangala (ca. $10^{\text {th }} / 11^{\text {th }} \mathrm{c}$.) (NAK 5/687 / NGMPP B 27/21), Bang 2017, 30, Table I.4 (one symbol is presented); in the manuscript of the Svacchandalalitabhairavatantra (ca. 11 ${ }^{\text {th }}$ c.) (NGMPP C 6/5) on 161r3_B/ACC; in the manuscript of the Kalyānakāmadhenūvivaraṇa (NS 224 / 1104 CE) (NAK 3/363 / NGMPP A 38/13, A 934/8) on 12r6_AC; in the manuscript of the Amarakoșațīka (NS 239 / 1119 CE) (KL 560 / NGMPP C 121/1), Pant 2000, part I, 78 and part II, 46, 48, 50, 143; IndoSkript, symbol, IS-Nr: 678-679; in 


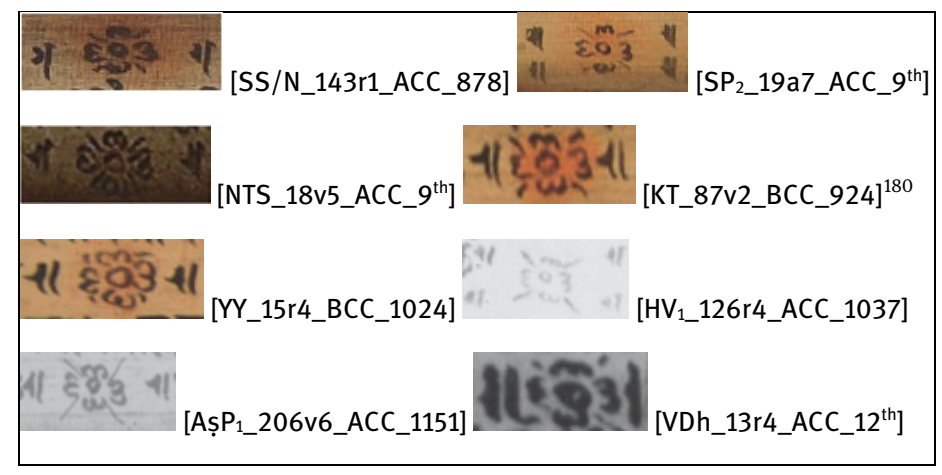

Fig. 3.4-XIV: Similar symbols

(15) Another type comprises a stylised pușpikā with a circle surrounded by four petals from which a little 'stroke' or 'tail' emerges ${ }^{181}$ Examples can be seen in Fig. 3.4-XV.

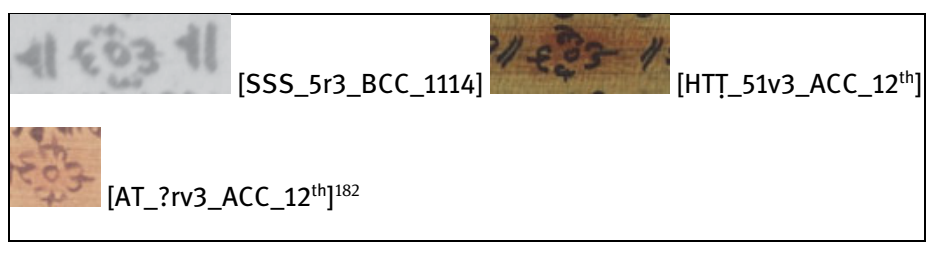

Fig. 3.4-XV: Similar symbols

(16) Similar to the symbol of the type no. 15, but with four petals and an additional four strokes on their sides is also to be found. ${ }^{183}$ This symbol appears before and/or

the manuscript of the Sārāvalī (NS 288 / 1168 CE) (NAK 5/700 / NGMPP A 31/10) on 6v5_ACC, 22r6_ACC, 70r2-3_B/ACC.

180 One similar symbol of this manuscript has also been listed by Bang 2017, 30 in Table I.4. 181 A quite similar symbol can also be found in the manuscript of the Pingālamata (NS 294 / 1174) (NAK 3/376 / NGMPP A 42/2), see Bang 2017, 30 in Table I.4.

182 Regarding the specific meaning of this symbol, see section 3.6.2.1.2 and Fig. 3.6.2.1.2-II below.

183 Quite similar symbols can be found in the manuscript of the Viṣnudharma (NS 167 / 1047 CE) (NAK 1/1002/1 / NGMPP A 1080/3) on 154v3_BC, Grünendahl 1983, 14 as Ms. N6, see IndoSkript, symbol, IS-Nr: 341; in the manuscript of the Svacchandalalitabhairavatantra (ca. $11^{\text {th }}$ c.) (NGMPP C 6/5), Bang 2017, 30, Table I.4 (one symbol is presented); in the manuscript of the 
after chapter colophons, colophons or other textual parts as well as around the string-hole (with the hole replacing the circle). Examples can be seen in Fig. 3.4-XVI.

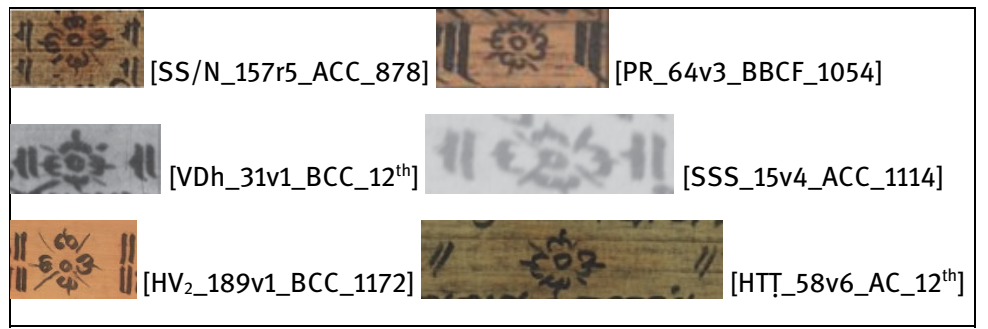

Fig. 3.4-XVI: Similar symbols

(17) Another type of symbol comprises one circle in the centre surrounded by four lines and four petals - with the petals made by joining two semi-circles. In the left and right petals one finds a further element containing a semi-circle with a stroke or a tail.

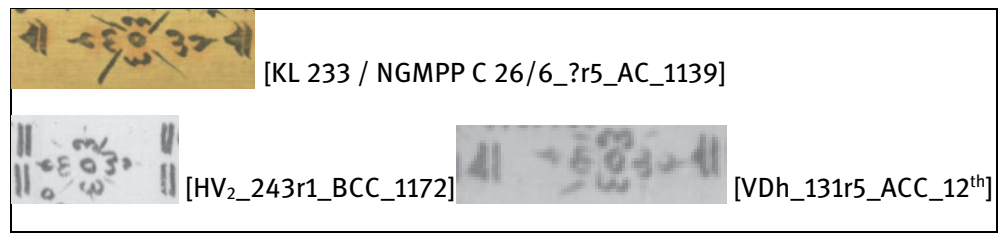

Fig. 3.4-XVII: Similar symbols

(18) A further type includes symbols containing a circle in the centre, four lines and four petals of which two petals, the right and left one, are followed by a futher petal-like elements with a 'stroke' or a 'tail'.

Fig. 3.4-XVIII: Similar symbols

Cāndravyākarana (NS 393 / 1243 CE) (KL 17 / NGMPP C 2/9) after the colophon; Roth 1986, symbol no. 5; see also section 3.6.2.1.3 for the specific meaning of the symbol in HTT. 
(19) The next type of symbol comprises a circle in the centre surrounded by four lines and four petals - with the petals made by joining two semi-circles followed by a semi-circular like feature and occasionally a 'stroke'. ${ }^{184}$

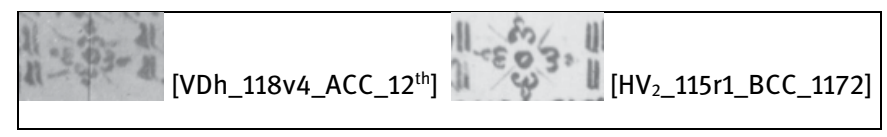

Fig. 3.4-XIX: Similar symbols

(20) Another type of stylised puspikā is comprised of a circle at the centre surrounded by more than four small semi-circular-like petals. ${ }^{185}$ Symbols can be found before and/or after the chapter colophon and also around the string-hole where the circle is replaced by the string-hole. Examples can be seen in Fig. 3.4-XX.

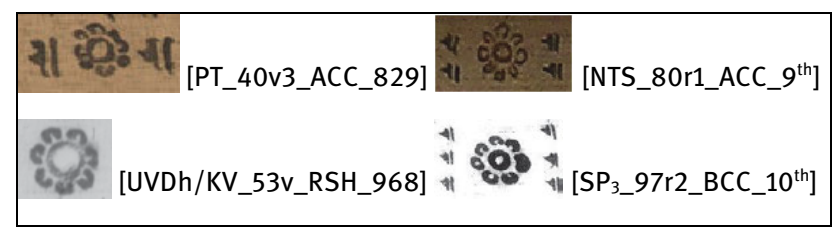

Fig. 3.4-XX: Similar symbols

(21) A further type of symbol containing 'double circles' or a circle with a 'dot' at the centre surrounded by more than four small semi-circular-like petals can be found after the chapter or colophon etc. in manuscripts (see Fig. 3.4-XXI).

184 A quite similar symbol appears in the manuscript of the Amarakoșațika (NS 239 / 1119 CE) (KL 560 / NGMPP C 121/1), see Pant 2000, part II, 325, IndoSkript, symbol, IS-Nr: 682.

185 Almost identical symbols can be found, (3 symbols) in the manuscript of the Sivadharmaśāstra (NS 192 / 1072 CE) (NGMPP E 2787/11), IndoSkript, symbol, IS-Nr: 181; in the manuscript of the Śivadharma corpus (ca. $11^{\text {th }}$ c.) (NAK 1/1261 / NGMPP A 10/5) after one of the chapter colophons (i.e. after the $16^{\text {th }}$ chapter colophon of the Vrsasārasamgraha) in line no. 1; in the manuscript of the Hitopadeśa (NS 604 / 1484 CE) (KL 16 / NGMPP C 2/8) on 99r4_B/ASpI, 99v34_B/AC. 


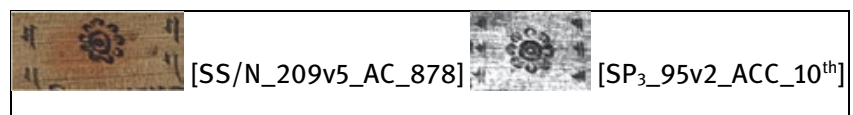

Fig. 3.4-XXI: Similar symbols

(22) Another type of symbol comprising a circle (with a dot) or double circles with eight petals is found in the manuscripts. They may appear before and/or after chapter colophons etc. One should note that the symbols look identical to some extent, but also exhibit some differences - the first symbol contains a circle with a dot at the centre, ${ }^{186}$ the second symbol contains double circles in the centre. Furthermore, nearly all petals of the first symbol contain a kind of 'tail' or 'stroke' added to them, whereas a few petals of the second symbol do not contain a 'tail' or 'stroke'.

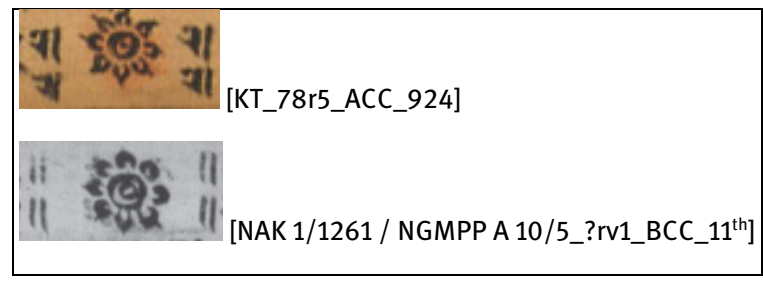

Fig. 3.4-XXII: Similar symbols

(23) Another type of 'almost similar' symbol comprises a symbol containing double circles at the centre and many petals is to be found in manuscripts. Please note that a few petals of the second symbol in the following Fig. look slightly different to those of the first symbol.

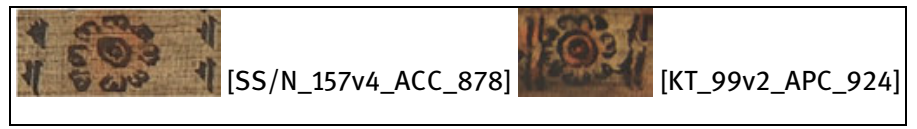

Fig. 3.4-XXIII: Similar symbols

186 An almost identical symbol with a circle in the centre can be found in the manuscripts of the Khandakhädya (NS 259 / 1139 CE) (KL 233 / NGMPP C 26/6) before the colophon. 
(24) The next type of almost identical symbol can be found in some manuscripts. This symbol appears before and/or after chapter colophons, around the string-hole etc. ${ }^{187}$ This symbol is somewhat similar in appearance to the form of symbols of the aforementioned type (Fig. 3.4-XXIII).

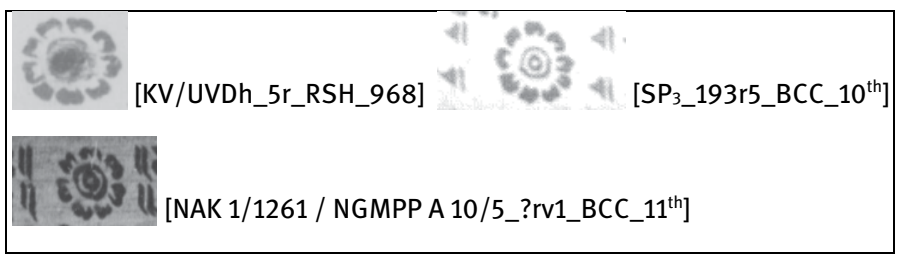

Fig. 3.4-XXIV: Similar symbols

(25) The next type of almost similar symbol comprises symbols made of a circle with or without a dot in the centre surrounded by a few number of dots. ${ }^{188}$

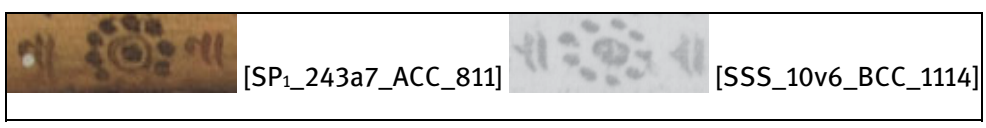

Fig. 3.4-XXV: Similar symbols

(26) Another type of simple symbol is a symbol containing a circle in its centre surrounded by some small circles. ${ }^{189}$ Examples can be seen in Fig. 3.4-XXVI.

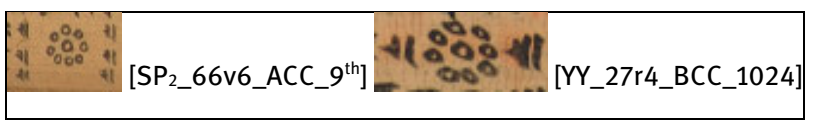

Fig. 3.4-XXVI: Similar symbols

187 A similar symbol can be found in the manuscript of the Sivadharmaśāstra (NS 156 / 1036 CE) (Calcutta, ASB G-4077), see IndoSkript, symbol, IS-Nr: 243.

188 A similar symbol containing a circle surrounded by seven dot-like elements can be found in the (paper) manuscript of the Caitanyabhāgavata (1690 CE) (Universitätsbibliothek Leipzig, Ms A 722), see IndoSkript, symbol, IS-Nr: 777.

189 A similar symbol can be found in Roth 1986, symbol no. 6. 
(27) The following type of stylised puspikā can also be found in some manuscripts. ${ }^{190}$ This symbol appears before and/or after chapter colophons, around the string-hole etc.

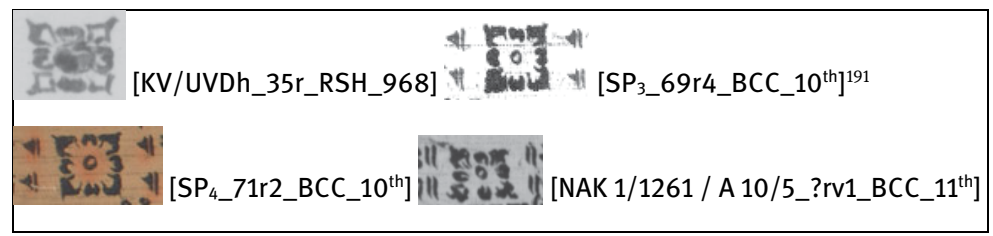

Fig. 3.4-XXVII: Similar symbols

(28) The type of symbol in the following Fig. 3.4-XXVIII can be found in manuscripts. All symbols appear before and/or after chapter colophons etc. The symbols take on the shape of a kind of 'rhombus'.

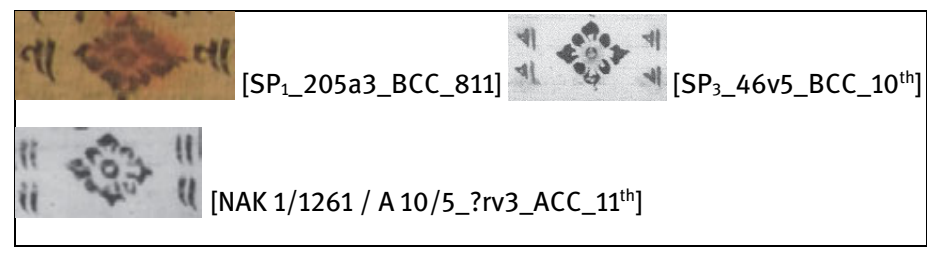

Fig. 3.4-XXVIII: Similar symbols

(29) Another type of similar symbol also has the form of a 'rhombus'. ${ }^{192}$

190 The symbol of KV/UVDh is almost identical to the symbol of $\mathrm{SP}_{3}, \mathrm{SP}_{4}$ and NAK 1/1261 / A 10/5. $\mathrm{SP}_{3}, \mathrm{SP}_{4}$ and NAK 1/1261 / A 10/5 are not dated and KV/UVDh is dated to $968 \mathrm{CE}$ (see also type nos. 20 and 24). The identical symbol of the dated manuscript KV/UVDh might be helpful to approximate the date of undated manuscripts $\mathrm{SP}_{3}, \mathrm{SP}_{4}$ and NAK 1/1261 / A 10/5. Thus it is possible that $\mathrm{SP}_{3}, \mathrm{SP}_{4}$ and NAK 1/1261 / A 10/5 might have been produced a few years before or after the production of KV/UVDh. See also section 3.8.2 below.

191 In $\mathrm{SP}_{3}$ similar symbols can be found on 26r6_BCC, 88r1_BCC, 136r4_ACC. These symbols of $\mathrm{SP}_{3}$ and the symbol of $\mathrm{SP}_{4}$ are discussed in section 3.8.2 below.

192 Attestations of similar symbols can also be seen in the manuscript of the Viṣnudharma (1220 CE) (NAK 2/51 / NGMPP A 1163/1), Grünendahl 1989, 3-4 as N15, IndoSkript, symbol, ISNr: 191. See also section 3.6.2.2, Fig. 3.6.2.2-IV an almost similar symbol like this can be obtained by joining stylised 'half-like' puṣpikās. 


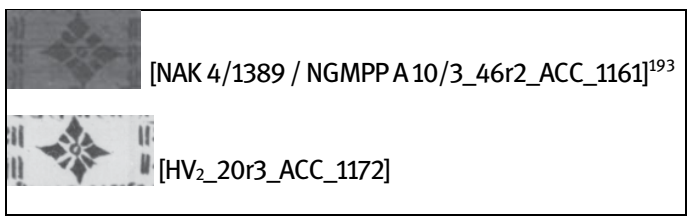

Fig. 3.4-XXIX: Similar symbols

(30) Another type of near similar stylised puspikā appears in manuscripts. ${ }^{194}$ The symbols can be found before and/or after chapter colophons etc. There is a small difference between the two symbols - the second one contains an extra four lines.

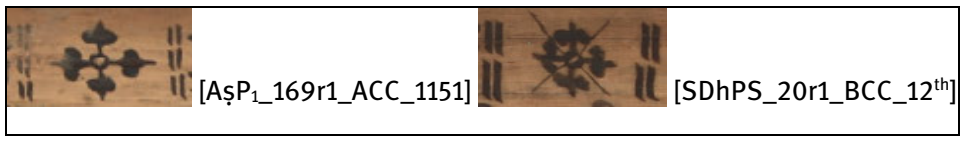

Fig. 3.4-XXX: Similar symbols

(31) A further type of symbol comprising a circle in the centre surrounded by eight 'sharp-formed' petals appears. ${ }^{195}$ The symbols can be found before the chapter colophon.

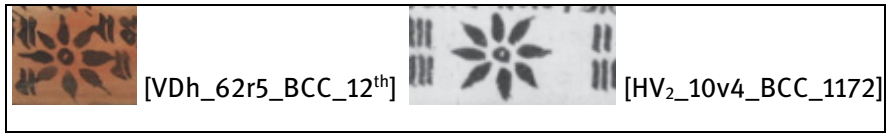

Fig. 3.4-XXXI: Similar symbols

(32) There is another type of similar symbol comprised of a symbol containing a circle with or without dot in the centre surrounded by four petal or petal-like

193 In this manuscript there are other near similar symbols before or after chapter colophons on 15vr4_BCC, 20r1_ACC.

194 I discuss the possible meanings and representations of these symbols in section 3.6.2.1.4 below.

195 A very similar symbol appears in the manuscript of the Pañcarakșā (NS 596 / 1476 CE) (NAK 1/1114 / NGMPP A 47/15) on 99r_BC (see section 3.6.2.16 below). 
features facing outside with a 'line' or 'stroke'. ${ }^{196}$ In the PR it can be found before the Buddhist concluding formula (i.e. idam avocad bhagavān ... 'thus spoke the Bhagavān ...') and in $\mathrm{TS}_{2}$ after the chapter colophon. ${ }^{197}$

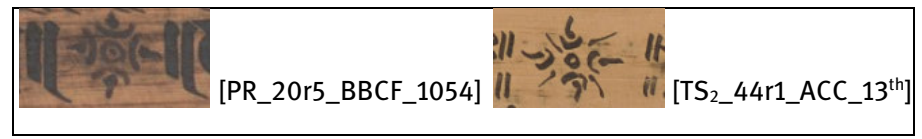

Fig. 3.4-XXXII: Similar symbols

(33) The next near similar type of symbol has a symbol containing four almost roundish petals or petal-like elements in the centre encircled by an outer circle.

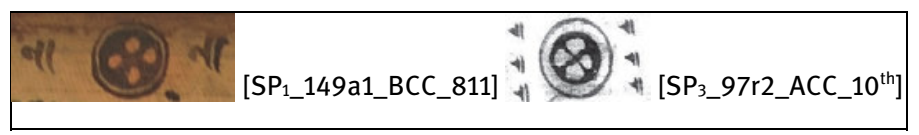

Fig. 3.4-XXXIII: Similar symbols

(34) Another near similar type of symbol can be found after chapter colophon, before the (Buddhist) opening formula etc. in manuscripts. Here the symbol is comprised of eight petals encircled by a circle. The petals are round, to a degree.

196 Near similar symbols appear in the Asoge Plates of Kadamba Jayakeśin (II) (1134 CE), EI 26, IndoSkript, symbol, IS-Nr: 438; in the manuscript of the Kārandavyūha (NS 478 / 1358 CE) (KL 112 / NGMPP C 12/3) before the colophon; in the manuscript of the Mudrārākșasa (NS 491 / 1371 CE) (NAK 1/1692 / NGMPP A 32/6) on 28v3-4_B/ACC, 62v4_BCC, 71r3_B/ACC; in the manuscript of the Vasundharādhäraṇi (NS 491 / 1371 CE) (KL 114 / NGMPP C 13/2) on 18v3_AC; in the manuscript of the Rāmāinkanāțikā (NS 496 / 1376 CE) (KL 73 / NGMPP C 6/9) on 42r3_BCC, 73v1_BCC, 146v3; in the manuscript of the Pañcarakșā (NS 509 / 1389 CE) (CUL Add.1701.1) on 153r1_ACC; in the manuscript of the Cāndravyākaraṇa (aka Śabdalakṣaṇavyākaraṇa) (ca. $15^{\text {th }}$ c.) (NAK 1/1697 / NGMPP B 35/25) on 7r4_BCC, 15r3_BCC, 27v1_BCC, 41v2_BCC, 48r2_BCC, 51r4_BCC, 53v3_BCC. For these types of symbols, see also Sarkar/Pande 1999, 52, Fig. 12,5-6.

197 An attestation of a symbol bearing some similarities to the form of this symbol can be seen before the colophon on 422v in the Greek manuscript Biblioteca Apostolica Vaticana, Vat.gr.1626 containing Homer's Iliad. The manuscript was copied in 1477 CE in Rome by the famous copyist Johannes Rhosos. Use of these near similar symbols in various manuscript cultures in different regions suggests the necessity for future comparative research at an international level. 


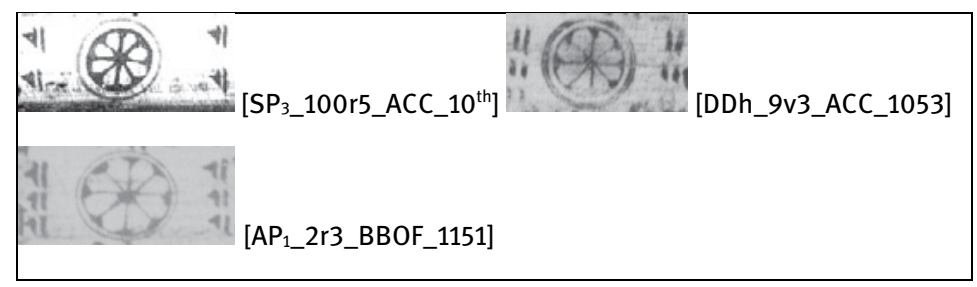

Fig. 3.4-XXXIV: Similar symbols

(35) Also found in manuscripts are those similar to type no. 34, but with an additional circle at the centre part. The symbols comprising eight petals and the outer part of petals are quite round. ${ }^{198}$ All inner parts of the symbols have been encircled.

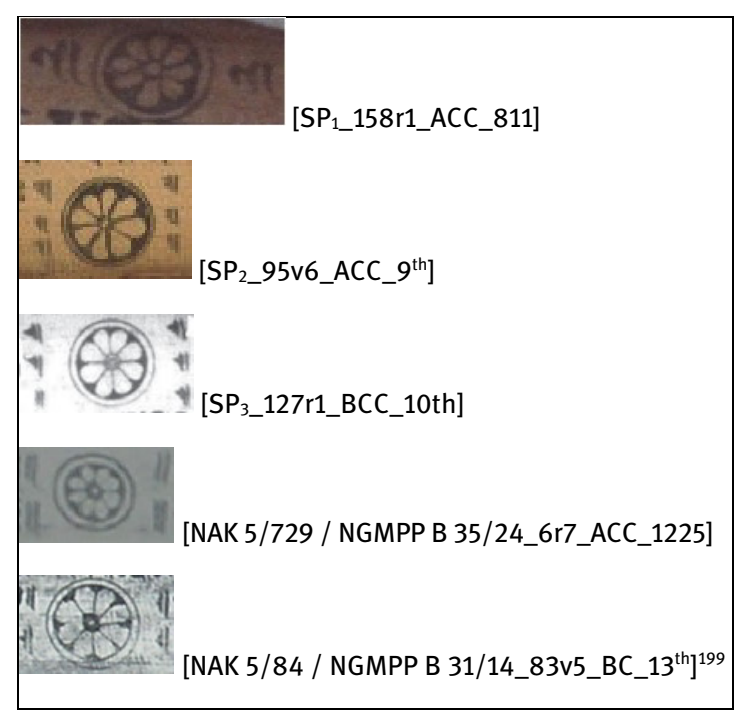

Fig. 3.4-XXXV: Similar symbols

198 Near identical symbols are in the manuscript of the Daśabhūmikasūtra (NAK 3/737 / NGMPP A 39/13) before the $2^{\text {nd }}$ and $5^{\text {th }}$ chapter colophon and after the $6^{\text {th }}$ chapter colophon and the manuscript is dated from ca. $5^{\text {th }}-7^{\text {th }}$ c. (see Matsuda 1996, xvi-xviii) and ca. $6^{\text {th }}$ c. (see Harimoto 2011, 93-95); in the manuscript of the Aștasāhasrikā Prajñāpāramitā (NS 128 / 1008 CE) (CUL Add.866) on 148r2_BCC, 162r3_ACC, 168v4_ACC; in the manuscript of the Śivadharmaśāstra (NS 156 / 1036 CE) (ASB G-4077), see IndoSkript, symbol, IS-Nr: 243.

199 This manuscript is also microfilmed as A 1297/10. 
(36) Also similar to type no. 35, but with petals of almost 'kite' shape are found in the manuscripts. Like symbols of type no. 35, the inner parts here have been encircled.

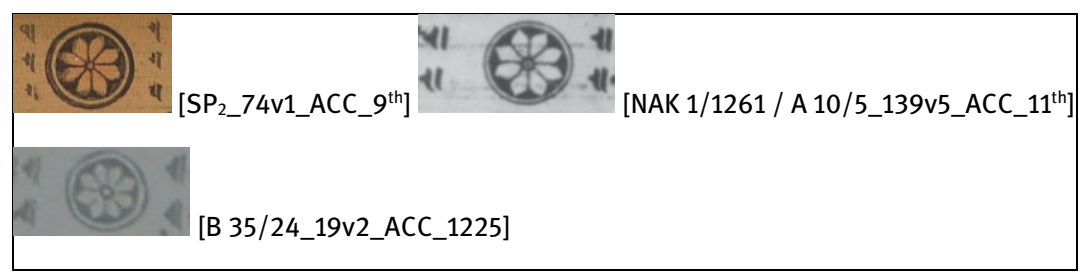

Fig. 3.4-XXXVI: Similar symbols

(37) Near similar to type no. 36, but with the inner part of the symbols encircled by double circles are also found in the manuscripts. ${ }^{200}$

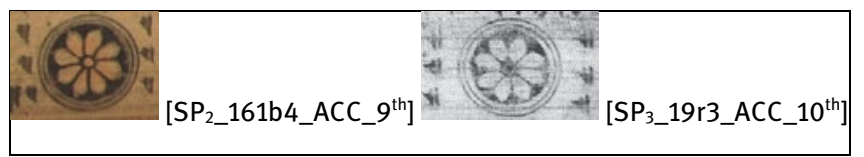

Fig. 3.4-XXXVII: Similar symbols

(38) Another type includes stylised puṣpikā comprising four virtually 'heartshaped' petals. The petals have been encircled. ${ }^{201}$

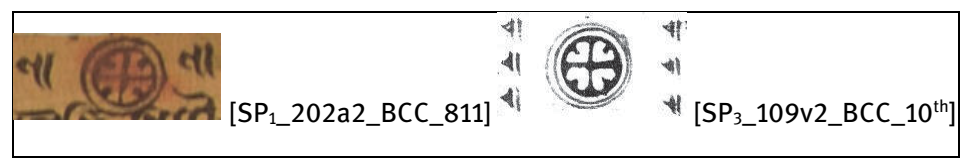

Fig. 3.4-XXXVIII: Similar symbols

200 An identical symbol is found in the manuscript of the Aștasāhasrikā Prajñāpāramitā (NS 128 / 1008 CE) (CUL Add.866) on 119r5_ACC.

201 An almost similar symbol is found in the manuscripts of the Daśabhūmikasūtra (NAK 3/737 / NGMPP A 39/13) before the $3^{\text {rd }}$ chapter colophon. The manuscript can be dated ca. $5^{\text {th }}$ $7^{\text {th }}$ c. (see Matsuda 1996, xvi-xviii) and ca. $6^{\text {th }}$ c. (see Harimoto 2011, 93-95); in the manuscript of the Kāśikāvivaranapañjikā (c. $10^{\text {th }} / 11^{\text {th }}$ c.) (NAK 4/216 / NGMPP A 52/13) on 245v6_ACC. 
(39) The next type includes a symbol containing eight petals of a virtual 'heartshape'. ${ }^{202}$ The petals have been encircled.

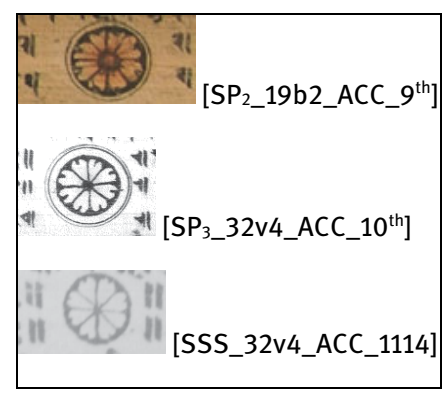

Fig. 3.4-XXXIX: Similar symbols

(40) Another type of near similar symbol comprising eight slightly curved petals running clockwise is found in manuscripts. ${ }^{203}$

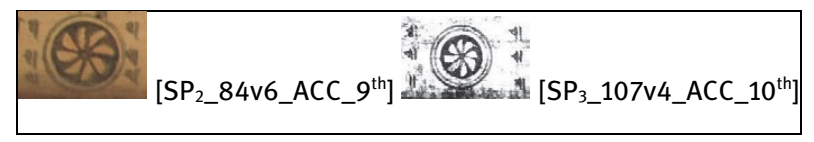

Fig. 3.4-XL: Similar symbols

(41) To some extent similar to type no. 40, but with more than eight curved petals running clockwise direction is found in the manuscripts. ${ }^{204}$

202 Almost identical symbols are found in the manuscript of the Daśabhūmikasūtra (NAK 3/737 / NGMPP A 39/13) after the $2^{\text {nd }}$ and $7^{\text {th }}$ chapter colophons. The manuscript is dated ca. $5^{\text {th }}-7^{\text {th }}$ c. (see Matsuda 1996, xvi-xviii) and ca. $6^{\text {th }}$ c. (see Harimoto 2011, 93-95).

203 An identical symbol is found in the manuscript of the Așțasāhasrikā Prajñāpāramitā (NS 128 / 1008 CE) (CUL Add.866) on 38v6_ACC.

204 Almost identical symbols also appear in the manuscript of the Aștasāhasrikā Prajñāpāramitā (NS 128 / 1008 CE) (CUL Add.866) on 13v4_ACC, 114r2_BCC. 


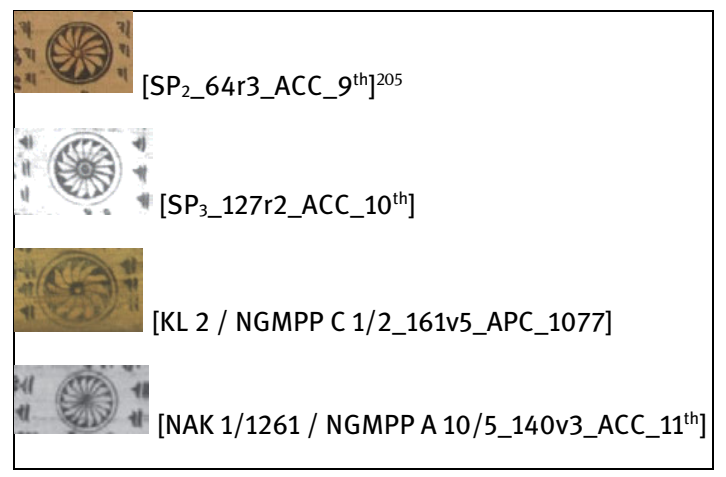

Fig. 3.4-XLI: Similar symbols

(42) Another type of symbol includes one of the types of the siddham ${ }^{206}$ (henceforth, siddham, siddham symbol) which can be found in manuscripts e.g. before an invocation, benediction or before the date in the post colophonic part etc.

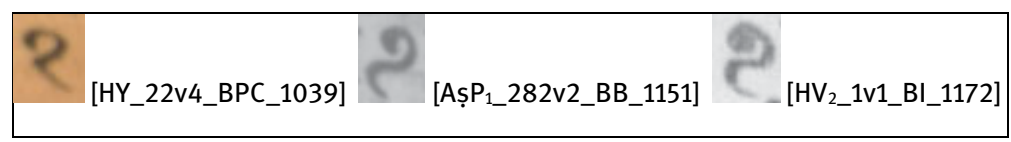

Fig. 3.4-XLII: Similar symbols

(43) Another type of siddham symbols often appear before invocations at the beginning of manuscripts. ${ }^{207}$ These manuscripts are purported to originate from Vikra-

205 Including this symbol (type no. 41), there are a few other symbols in $\mathrm{SP}_{2}$ and $\mathrm{SP}_{3} / \mathrm{SP}_{4}$ (with regard to the connection of $\mathrm{SP}_{3}$ and $\mathrm{SP}_{4}$, see section 3.8.2 below) which look quite similar in appearance e.g. type nos. 8, 35, 37, 39, 40. Furthermore, $\mathrm{SP}_{2}$ contains two realistic puṣpikās (see section 3.5.1, Fig. 3.5.1-I below). Similarly, three realistic puspikās can also be found at the end of the chapters in $\mathrm{SP}_{3}$ (see section 3.5.1, Fig. 3.5.1-II). This evidence of the use of a few almost similar symbols can imply that the scribe of $\mathrm{SP}_{3} / \mathrm{SP}_{4}$ was probably familiar with the symbols of $\mathrm{SP}_{2}$ or that he may have consulted the $\mathrm{SP}_{2}$ while copying the text.

206 For discussion of the term and examples of further 'siddham' symbols, see Sander 1986, 251-261; Roth 1986, 239-249. A nearly similar siddham symbol can also be found in the CopperPlate of Śivadeva (NS 221 / 1100 CE), Pant/Sharma 1977, IndoSkript, symbol, IS-Nr: 753; in the manuscript of the Pingālamata (NS 294 / 1174) (NAK 3/376 / NGMPP A 42/2) on 1v_BI, see also Bang 2017, 30, Table I.4.

207 An almost identical symbol can be found in the Nālandā Inscription of Vipulaśrīmitra (1100-1151 CE), see IndoSkript, symbol, IS-Nr: 519. 
maśila. A tiny 'dot-like' element appears added to the top-right side of most of the symbols (namely in GV, HAP, DVPT, AP, CPN). In its appearance the symbol resembles to a degree the figure-numeral ' 7 ' found in manuscripts (e.g. the foliation for 7 on the left-hand margin on 7v in AAĀ, LTT, DVPT, HAP, HP). ${ }^{208}$

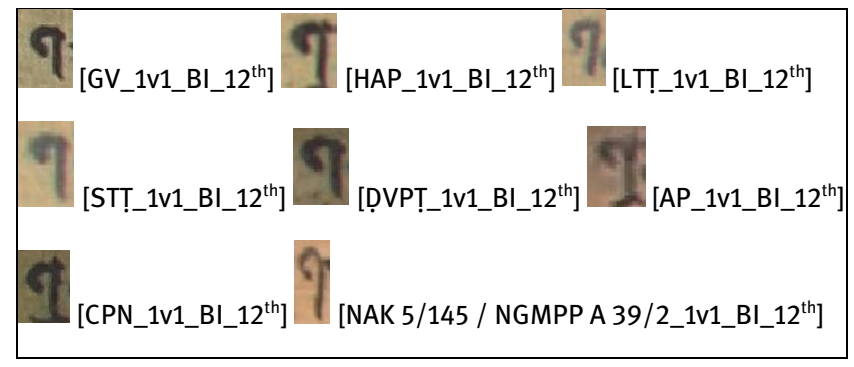

Fig. 3.4-XLIII: Similar symbols

(44) A further type of siddham symbol ${ }^{209}$ can be found e.g. before the invocation, before and/or after chapter colophons etc., in manuscripts.

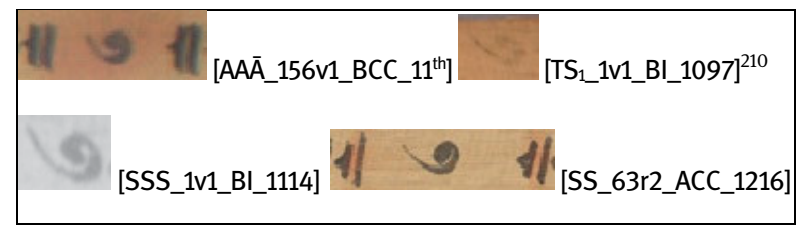

Fig. 3.4-XLIV: Similar symbols

(45) Another type of siddham symbol can also be found in manuscripts. Among them five may possibly originate from Vikramaśīla and the other one (i.e. AAĀ)

208 For the first numeral in the third row, numerals in the fourth and tenth rows, see Bendall 1883, appendix, Figure-numerals.

209 An almost similar symbol appears in the Taukhel Inscription of Amśuvarman (613 CE), see IndoSkript, symbol, IS-Nr: 604; in the manuscript of the Bhairavamangala (ca. $10^{\text {th }} / 11^{\text {th }} \mathrm{c}$.) (NAK 5/687 / NGMPP B 27/21) on 1v1_BI, Bang 2017, 30, Table I.4; in the manuscript of the Kubjikāmata (NS 212 / 1092 CE) (NAK 1/1077 / NGMPP B 25/24) on 1v_BI, Bang 2017, 30, Table I.4; in the manuscript of the Viṣnurahasya (1195 CE) (NAK 3/380 / NGMPP B 29/4), see IndoSkript, symbol, IS-Nr: 208. See also Sarkar/Pande 1999, Figs. 7-10 for examples of 'siddham'.

210 The same symbol has also been listed by Bang 2017 in 30, Table I.4. 
from a nearby area. ${ }^{211}$ Interestingly most of them have a near identical shape. Their head, slightly curved inside is followed by a curved 'tail' which always extends to the left. A tiny hook-like line or dot-like element often appears to the upper-right side of the symbol. This symbol resembles the character ' $t$ ' also found in manuscripts (see section 3.5.2, Fig. 3.5.2-I below).

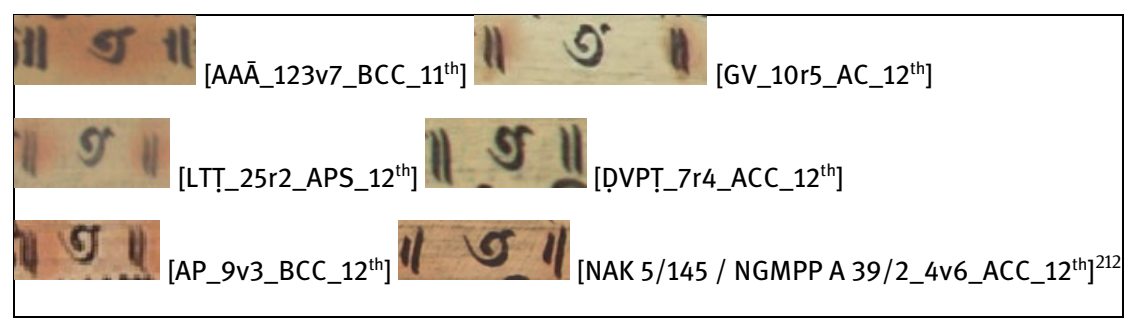

Fig. 3.4-XLV: Similar symbols

(46) Another type of symbol appears resembling the character 'tha'213 or the letter-numeral for '20' (henceforth 'tha' or 'tha' symbol). ${ }^{214}$ This symbol can be found, before and/or after chapter colophons, before the (Buddhist) concluding formula (BCF) or before and/or after a particular text section etc. ${ }^{215}$ In addition, a

211 An almost identical symbol appears in the manuscript of the Abhisamācārikadharma (1000-1100 CE), see IndoSkript, symbol, IS-Nr: 306. At least 12 almost identical symbols can be seen in the manuscript of the Vimalakürtinirdeśa/Jñānālokālaṃkāra (1000-1300 CE), see IndoSkript, symbol, IS-Nr: 597. See also Roth 1986 and Sander 1986 for almost identical symbols of this type.

212 Further siddham symbols can be found on 5v7_ACC, 7r3_ACC, 10v7_B/AC.

213 For the letter 'tha', see Bendall 1883, Table of Letters; Bühler 1896, Tafel IV, row 23 and Tafel V, row 26; Dani 1963, plate Xia; Sander 1968, Tafel 27.

214 For instance, the letter-numerals for ' 20 ', see Bendall 1883, Table of Letter-numerals; Bühler 1896, Tafel IX.

215 Further attestations of the 'tha' are in the manuscript of the Pālībhāṣāyam Vinaya (ca. $8^{\text {th }}-9^{\text {th }} \mathrm{c}$.) (NAK 3/737 / A 1151/2 and A 39/13), Einicke 2009, 138, 286 as New1(775!)_1; in the manuscript of the Nišvāsamahātantrāntargatapratișthātantra (NS 180 / 1060 CE) (NAK 1/279 / NGMPP A 41/15-A 42/1), Bang 2017, 30, Table I.4 (one tha is presented); in the manuscript of the Sivadharmaśātra (NS 189 / 1069 CE) (NAK 3/393 / NGMPP A 1082/3), Einicke 2009, 144, 286 as New6(1069)_1; in the manuscript of the Aștasāhasrikā Prajñāpāramitā (ca. 12 ${ }^{\text {th }}$ c.) (KL 18 / NGMPP C 103/2) on 170r1_BCC; in the manuscript of the Vișnudharma (NS 281 / 1161 CE) (NAK 4/1389 / NGMPP A 10/3) on 122v1_BCC, 123r5_BCC, 124v1_ACC, 125r5_B/ACC, 126r5_B/ACC; in the manuscript of the Sivadharma corpus (ca. $12^{\text {th }}$ c.) (CUL Add.2102) on 113r5_ACC, 319r3-4_B/ACC. 
set of many 'thas' has also been used both as line-fillers ${ }^{216}$ or space-fillers ${ }^{217}$ in manuscripts.

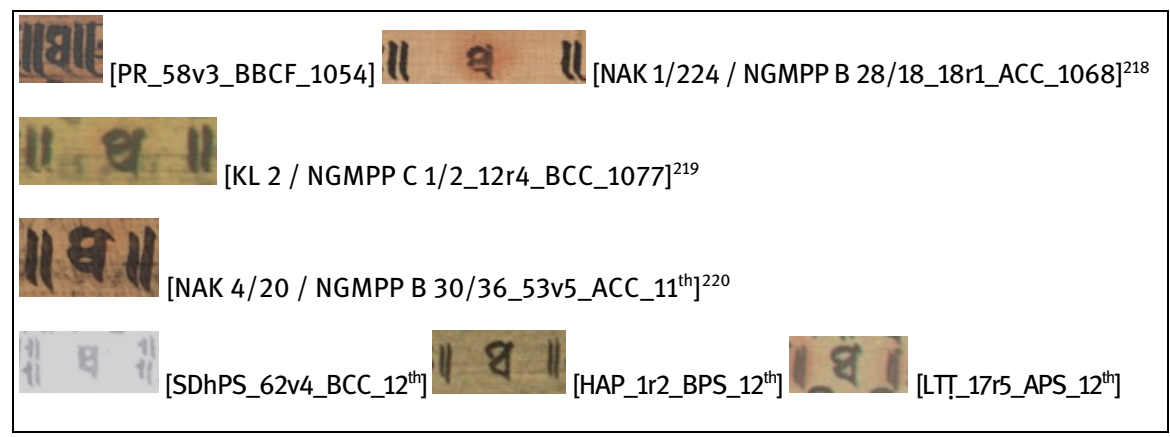

Fig. 3.4-XLVI: Similar symbols

(47) Another type of symbol includes a symbol that resembles the character 'cha'221 (hereafter 'cha' or 'cha'-like symbol or 'cha' symbol). The symbol can be found be-

216 'Thas' are used as line-fillers in the manuscript of the Śivadharma corpus (ca. $12^{\text {th }}$ c.) (CUL Add.1645) on 44r1-2, 59r1, 67r1.

217 They are found as space-fillers in $\mathrm{HV}_{1}$ on 220r5; in $\mathrm{DDh}$ on 46v5. In West Indian manuscripts they are used as space-fillers in TSPV on 93v7 and in TUS on 36v3.

218 Further attestations of the symbol in the manuscript can be found on 5r4-5_B/ACC, 18r1_ACC, 51v2_ACC, 74v6_ACC, 150v3_ACC, 157v4_ACC, 159v5_ACC, 162v4_B/AC; see also Bang 2017, 30, Table I.4 (one tha is presented).

219 Further attestations of the symbol in this manuscript can be found on 10v1_BCC, 14r5_B/ACC, 14v1_ACC, 14v3_B/ACC, 15r1_B/ACC, 16r1-2_B/ACC, 16v1_B/ACC.

220 Further attestations in the manuscript can be found on 11v5_ACC, 14v3_ACC, 50v5_B/ACC, 53v5_BCC.

221 In terms of meaning, appearance, use of the symbol I quote here some selected descriptions by scholars to help obtain an overview of it. Bühler 1896, 85: “... Da der Kreis mit einem Puncte $\odot$ dem alten tha entspricht, so werden andere, späteren tha ähnliche, oder gleiche Zeichen dafür gebraucht und in den modernen MSS. erscheint schliesslich das dem tha sehr ähnliche छ””; Tripāthī 1975, 48: “'cha', 'śrì'. A portion of the Scribal Remarks consists of numerous Akșaras of this type (cha, śrī, śrīh). The oldest record of the use of cha to indicate the end, which we could trace, is a 'Turfan' fragment (Kat. Nr. 816 [R4]) ... For Śrīharṣa’s reference to 'cha' (in his Naișadhīyacarita, 10.87 and 16.98) vide Nārāyaṇa’s commentary on these verses (NSP 1952, 431, and 669: grantha-lekhana-samāpti-patre samāpti-sūcakaṃ chakārādi-vartulam akșaraṃ kriyate) and A. N. JANI, A Critical Study ... (Baroda OI, 1957), 215. ... The meaning of this sign and of other signs (whether identical with Akșaras and figures, or not) is unknown"; Thaker 2002, 170: "At the close of the Mss, before and even after the PRAŚASTIs, we find such benedictions as: 'शुभं भवतु', 'कल्याणमस्तु', 'मंगलं महाश्री:', 'लेखकपाठकयोः शुभं भवतु', etc. Similarly such symbols as ' 
fore and/or after chapter colophon, colophon etc. in manuscripts. ${ }^{222}$ Generally the manuscripts in which we find such types of symbols come from West India.

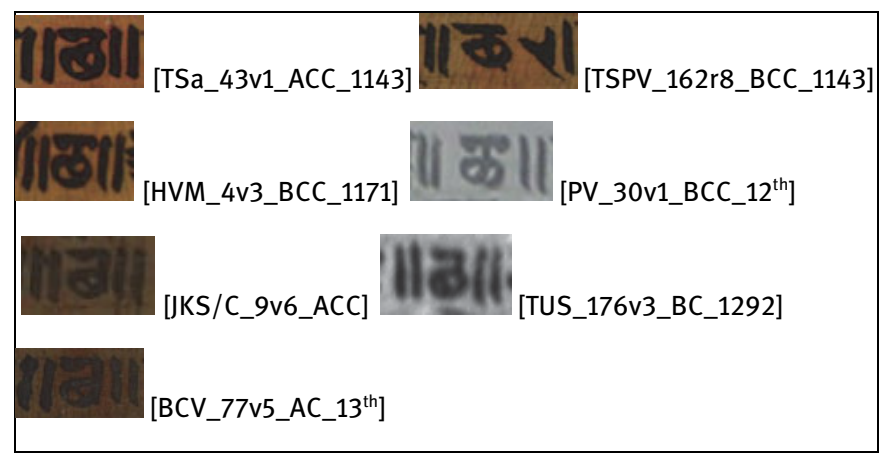

Fig. 3.4-XLVII: Similar symbols

symbols are seen at the close of sections or topics also. On observation of these symbols in a number of Mss MUNIJI has come to the conclusion that they represent पूर्णकुम्भ (PŪRNAKUMBHA) or a Full JUG which is regarded as auspicious in India for all affairs. As such in Mss they indicate 'auspicious completion'. Such other symbols as 'They might be picture-designs indicative of 'conclusion'. In a number of Mss certain other designs are drawn in order just to draw attention to the closure of sections or chapters. They also may be regarded similar to the same.” Balbir 2006, 68 reports as follows: "The Scribal Remark generally contains syllables such as śri or cha. The origin and the meaning of the latter ... are rather mysterious and have not been elucidated so far. Sometimes, it appears that series of such syllables, separated or not by dandas, were written simply to finish the line (or the page) and avoid blank spaces."

222 Similar symbols can be found in the manuscript of the Kavalayamala (1038 CE), see Einicke 2009, 106, 285 as Nag1(1038)_1; in the manuscript of the Śantināthaboli (1293 CE) (L.D. Institute, Ahmedabad ms. 8484), Einicke 2009, 107, 285 as Nag2(1293)_1; in the (paper?) manuscript of the Jyotiș Ratnakośa (1445 CE) (L.D. Institute, Ahmedabad ms. 8261), Einicke 2009, 116, 285 as NaJ1(1445)_4; in the (paper) manuscript of the Kālakācāryakathā (VS 1516 / 1459 CE) (L.D. Institute, Ahmadabad, ms. 419), see IndoSkript, symbol, IS-Nr: 333; in the (paper) manuscripts of the Raghuvaṃśa (1500 CE) (Universitätsbibliothek Leipzig, Ms A 375), Einicke 2009, 119, 285 as NaJ3(1500)_13; in the (paper?) manuscript of the Mahāpurāṇa (1540 CE), Einicke 2009, 109, 285 as Nag4(1540)_2; in the (paper) manuscript of the Atharvaveda (1550 CE) (Universitätsbibliothek Ms A 93), Einicke 2009, 121, 285 as NaJ4(1550)_10; in the (paper) manuscript of the commentary on the Kumārasambhava (1582 CE) (Universitätsbibliothek Leipzig Ms A 372), Einicke 2009, 128, 286 as NaJ6(1582)_21; in the (paper) manuscript of the Abhidhānacintāmaṇi Nāmamālā (1585 CE) (Universitätsbibliothek Leipzig Ms A 800), Einicke 2009, 129, 286 as NaJ7(1585)_3; in the (paper) manuscript of the Grahasiddhi (VS 1695 / 1638 CE) (L.D. Institute, Ahmadabad, ms. 8825), see IndoSkript, symbol, IS-Nr: 331; in the (paper) manuscript of the Naișadhiyaprakāśa (1650 CE) (Universitätsbibliothek Leipzig Ms A 397), Einicke 2009, 132, 286 as NaJ9(1650)_15. See also Sarkar/Pande 1999, Fig. 15, 18. 
At this stage it is perhaps too early to present the above mentioned types in terms of region or exclude further possibilities of their occurrences. Certainly the list of 'similar' types of symbols may be extended. Indic manuscript culture is so vast, there are many more symbols and other elements that are not be included in this study, due to the project's limited timeframe, resources etc. I hope future studies will reveal more new insights and examples to enable an even better understanding of the use of symbols, scribal practice etc. Nonetheless, the examples presented above provide some ideas on the frequency of use of symbols in one or more areas.

We have seen a few types of 'similar' or 'near similar' symbols; from 'dots' to double circles to letter or letter-numeral-like symbols to simple stylised puṣpikās and beautiful stylised puṣpikās. Some stylised pușpikās are used both before and/or after chapter colophons and around string-hole(s) (e.g. type nos. 8, 12, 20, 24, 27) or before and/or after chapter colophons and with foliation numbers (type nos. 7, 8). The symbol of type no. 46 can be found before and/or after chapter colophons or other sections or as line-fillers or space-fillers.

Some symbols are used interchangeably as akșaras or figure- or letter-numerals in manuscripts. Type nos. 4 and 5 can be used either as symbols or as some of the letter-numerals for ' 80 '. The symbol of type no. 43 resembles the figure-numeral for '7'. The symbol of type no. 45 is used both as one of the types of siddham symbol or as an akșara ' $t$ ' (without vowel). The symbol of type no. 46 can be used both as akșara tha and as the letter-numeral for '20'.

Of the 47 types of near 'identical symbols' only two (type nos. 4 and 46) appeared in manuscripts from all three areas focused on here. Of the 47, near 'identical symbols' seven (type nos. 1, 2, 5, 15, 16, 32, 44) appear mainly in Nepalese and East Indian manuscripts. Four (type nos. 7, 8, 10, 12) appear only in Nepalese and West Indian manuscripts. Thirty (type nos. 3, 6, 9, 11, 14, 17-31, 33-42) appear largely in Nepalese manuscripts. Three (type nos. 13, 43, 45) appear only in East Indian manuscripts and one (type no. 47) appears only in West Indian manuscripts.

\subsection{Further types of symbols related to particular areas}

Some types of symbols may have been used often or exclusively in manuscripts from one particular region. Their analysis may help locate the area where the manuscripts were (possibly) produced or the scribal practice, in combination with palaeographical evidence and the study of layout, etc. 


\subsubsection{Symbols in Nepalese manuscripts}

As we have seen, a large variety of symbols of remarkable aesthetic value has been used in manuscripts. Nepalese manuscripts often contain unique types of symbols, as shown in the previous section (see type nos. 3, 6, 9, 11, 14, 17-31, 33-42; and see also Appendix I for other typical symbols which are not included in the list above). This section describes another type of unique symbol that I previously labeled as realistic puspikās (see section 3.1 above), i.e. those resembling 'real flowers' with stalks and/or leaves or sepals etc. drawn. ${ }^{223}$ I have found these in some Nepalese manuscripts. The manuscripts featuring these kinds of realistic flowers listed here date from ca. $9^{\text {th }}$ to $13^{\text {th }} c .^{224}$ The manuscripts $\mathrm{SP}_{2}, \mathrm{SP}_{3}$ and the manuscript of the Viṣnudharma ${ }^{225}$ contain puranic texts. Whereas, HY and the manuscript of the Kulälikāmnāyatantra ${ }^{226}$ contain Śaiva tantric texts. Four manuscripts (i.e. the manuscript of the Saddharmapundarika; ${ }^{227}$ the Śatasāhasrikā Prajñāpāramitā ${ }^{228}$ the Aștasāhasrikā Prajñāparamitā $\bar{a}^{229}$ and $\mathrm{AșP}_{1}$ ) contain Buddhist Sūtras. One manuscript of the Kalyānakāmadhenūvivarana ${ }^{230}$

223 An example of the realistic pușpikā with a curved stalk and two buds can be found in the Chidivalasa plates of Devendravarman (893-895 CE), see Sarkar/Pande 1999, 8, Fig. 11, 7; at the end of the stone inscription of the time of Aśokacalladeva (Bodhgaya, Bihar) (ca. 1194 CE), EI 12, IndoSkript, symbol, IS-Nr: 731, Sarkar/Pande 1999, 89, Fig. 11,16. Here, in terms of form, the realistic puṣpikā resembles a 'sunflower'. Large realistic puṣpikās can also be found in some (Nepalese) inscriptions. A large realistic pușpikā with leaves and buds clearly resembling a lotus is in the upper part of the Inscription of Jayadeva, see Indraji 1885, No. 15, see also Sarkar/Pande 1999, 89, Fig. 26. Similarly, in the upper part of another Inscription of Śivadeva, one can find realistic puspikās with buds etc., see Indraji 1885, No. 5.

224 Other realistic pușpikās can be found in later Nepalese manuscripts e.g. a realistic pușpikā appears in the manuscript of the Mahāsahasrapramardini (ca. 15 ${ }^{\text {th }}$ c.) (KL 252 / NGMPP C 27/11) before the chapter colophon on 108r and the colophon reads (in line nos. 1-2) as follows: 'āryamahāsítavatī nāma mahāvi||[2]dyā mahānumamsā̄(!) samāptā'. A siddham symbol is found after the colophon. Furthermore, two realistic pușpikās are found in the manuscript of the Pañcarakșa $\left(\right.$ ca. 17 ${ }^{\text {th }}$ c.) (KL 105 / NGMPP C 11/2) on 160v. The first realistic puspiki ā appears after the chapter colophon in line no. 1. But the second realistic puspika can be found around the right string-hole space. Additionally a stylised pușpikā is also drawn around the left string-hole on the same folio. Two other symbols of this manuscript are presented in section 3.6.2.1.6 below. On the discussion of the possible date of this manuscript, see the footnote in section 3.6.2.1.6 below.

225 See NAK 4/766 / NGMPP A 10/1.

226 See NAK 5/877 / NGMPP A 41/3.

227 See CUL Add.2197.

228 See Royal Library, Copenhagen, Nepal 175A.

229 See KL 18 / NGMPP C 103/2.

230 See NAK 3/363 / NGMPP A 38/13. 
contains a commentary on a Buddhist tantric text. One manuscript of the Antarvyāptisamarthana ${ }^{231}$ contains a Buddhist work on logic, one manuscript contains a commentary on the Nitisārapañjikā (Jayamañgalā). ${ }^{232}$

All these realistic flowers appear mainly at the end of chapters or at the end of the text. Based on the frequency of examples, it seems that realistic pusppikās in Nepalese manuscripts may have been a significant element.

In $\mathrm{SP}_{2}$ two realistic puspikās can be found. One appears after the $45^{\text {th }}$ chapter colophon on $66 \mathrm{v} 2^{233}$ and looks like a tulip in terms of appearance. The other at the end of the $6^{\text {th }}$ line exactly under the right string-hole (on 207b) (see Fig. 3.5.1-I below). The height of the first puspikā corresponds to three text lines of the folio. Given the shape's level of refinement, one may speculate that both realistic puspikās were drawn later than some of other symbols found in the same manuscript.

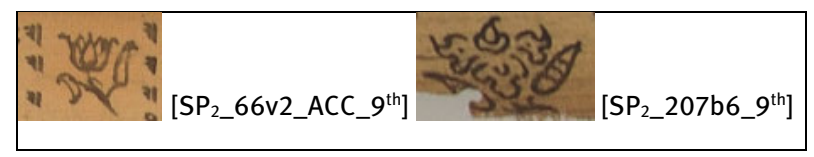

Fig. 3.5.1-I: Realistic puṣpikās after the chapter colophon and at the end of last line

In $\mathrm{SP}_{3}$ at least three realistic pusppikās can be found on 70r1, 70v1 and 244v3. The first realistic puspiki ā appears before the $40^{\text {th }}$ chapter colophon on 70r1. ${ }^{234}$ Similarly, the second realistic puspikā appears before the $41^{\text {st }}$ chapter colophon on 70v1 and the third one before the $136^{\text {th }}$ chapter colophon on $244 \mathrm{v} 3$. The height of the two pusppikās on 70r1, 70v1 is approximately two text lines of the folio and the other's height on $244 \mathrm{v} 3$ is approximately three text lines on the folio (see Fig. 3.5.1-II).

231 See NAK 3/364 / NGMPP B 23/34.

232 See KL 77 / NGMPP C 6/13.

233 The chapter colophon reads iti || skandapurāne pañca|๑|catvārimśatimo dhyāyah ('thus, the $45^{\text {th }}$ chapter in the Skandapurāna [is concluded]').

234 The chapter colophon reads skandapurāne ddhyāyah | pta ("[thus], the chapter in the skandapurāna [is concluded]. 40.'). 


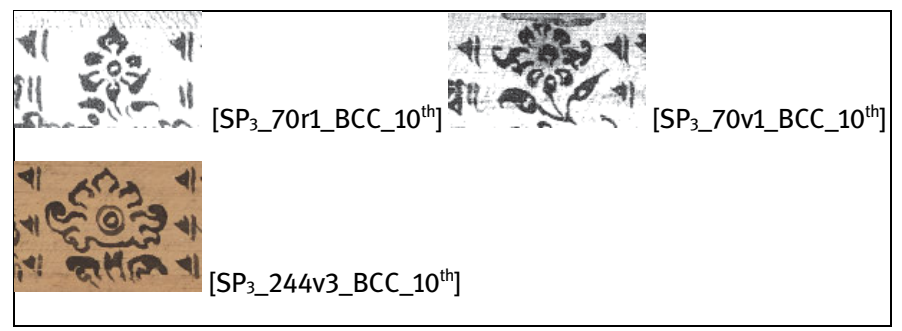

Fig. 3.5.1-II: Realistic pușpikās before and after the chapter colophons

Additionally, one realistic pușpikā can be found in the manuscript of the Kulālikāmnāyatantra (NAK 5/877 / NGMPP A 41/3) on 92v2. The manuscript is dated NS 158 (1037 CE). ${ }^{235}$ The puspika appears before the $19^{\text {th }}$ chapter colophon..$^{236}$ The height of the puspikā is two lines of the folio. An example can be seen in Fig. 3.5.1-III.

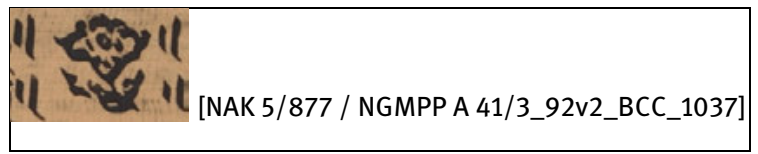

Fig. 3.5.1-III: Realistic pușpikā before the chapter colophon

In HY two realistic puṣpikās appear at the end of chapters. ${ }^{237}$ The first realistic puṣpika is after the $9^{\text {th }}$ chapter colophon on $14 \mathrm{r} 3^{238}$ and the second realistic puṣpikā after another chapter colophon on $19 \mathrm{v} 5 .{ }^{239}$ The height of the pusppikā on $14 \mathrm{r} 3$ is two text lines and on 19v5, it slightly more than one line of the folio, although it is demarcated by the one set of double daṇa. The puṣpikā appears in the last line on the folio. Both examples can be seen in Fig. 3.5.1-IV.

235 See Goudriaan and Schoterman 1988, 14. They have used the manuscript as siglum Z in their edition.

236 It reads on 92v2-3 as follows iti laghvikāmnāye śrīmatkubjikāmatottare șațprakāre[3] catușkasya rūpe pațalāntaraṃ ūnaviṃśatimaṃ.

237 These two realistic pușpikās have also been used by Bang 2017, 30, Table I.4.

238 It reads iti paramārșasaṃhitāyām | hansamyyā(!) savinimṇayo na $\odot$ vamaḥ pațala.

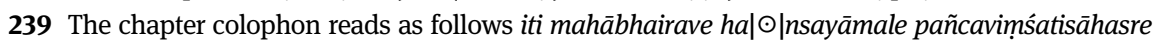
aṃśakapațalah. 


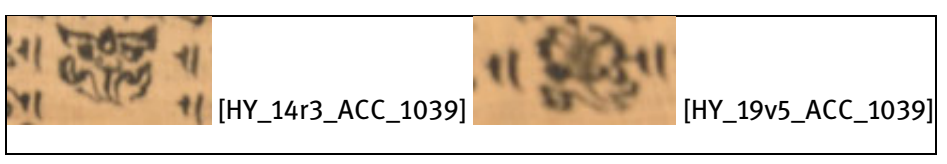

Fig. 3.5.1-IV: Realistic pușpikās after the chapter colophons

In the manuscript of the Saddharmapundarinkasūtra (CUL Add.2197) dated from NS 185 (1065 CE), there are realistic pușpikās in most of the chapter colophons. They appear after the $7^{\text {th }}$ chapter colophon on $58 \mathrm{r} 1$, before and after the $8^{\text {th }}$ chapter colophon on $62 \mathrm{r} 2$ and before and after the $9^{\text {th }}$ chapter colophon on $64 \mathrm{r} 5-6 . .^{240}$ Their height is one to three lines of the folio (see Fig. 3.5.1-V). The realistic pusppikās are demarcated by three sets of double dandas of only two lines in height (on 62r2, $64 \mathrm{r} 5,77 \mathrm{v} 1-2,82 \mathrm{r} 5,94 \mathrm{r} 4,123 \mathrm{v} 4,130 \mathrm{v} 3$ ) and those demarcated by four sets of double dandas are only three lines in height (on 120r4, 131r2). Please note that after the $24^{\text {th }}$ chapter colophons on 123v4 two realistic pușpikās appear. All of these realistic puspikās in this context may well be considered representations of padmas ('lotuses'). This manuscript is discussed for its use of other symbols and their importance later in section 3.6.2.4.2.

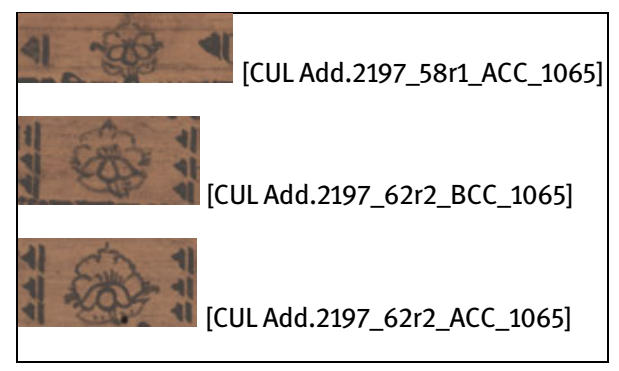

240 Further examples of realistic puspikās can be found before and after the $12^{\text {th }}$ chapter colophon on $77 \mathrm{v} 1-2$, after the $13^{\text {th }}$ chapter colophon on $82 \mathrm{r} 5$, before and after the $17^{\text {th }}$ chapter colophon on $94 \mathrm{r} 4$, after the $24^{\text {th }}$ chapter colophon $120 \mathrm{r}$, after the $24^{\text {th }}$ chapter colophon on $123 \mathrm{v} 4$, before the $26^{\text {th }}$ chapter colophon on $130 \mathrm{v} 3$ and before the $27^{\text {th }}$ chapter colophon on 131v2. The chapter colophon on 120r3 and the following chapter colophon on $123 \mathrm{v} 4$ record the same number ' $24^{\text {th' }}$ for the both chapters. The former one reads on 120r3 garggadasvaraparivartto(!) nāma caturvinśatimah and the latter one on $123 v 4$ records as follows samantamukhaparivartto nāmāvalokiteśvaravikurvanirdeśaś(!) caturvinśatimah. If the name of the chapter of the first one on 120r is read correctly it should be the 'gadgadasvaraparivarta' and therefore $23^{\text {rd }}$ chapter rather than the $24^{\text {th }}$ chapter. The scribe was probably confused by the writing of the chapter number. 


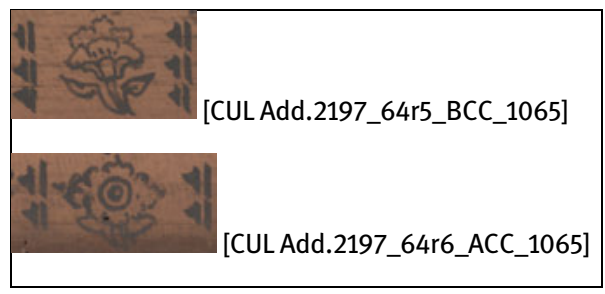

Fig. 3.5.1-V: Realistic pușpikās before and/or after the chapter colophons

In the manuscript of the Kalyānakāmadhenūvivarana (NS 224 / 1104 CE) (NAK 3/363 / NGMPP A 38/13) there is a realistic puṣpikā before the colophon on 11r5.241 After the colophon a stylised puspikā appears in line no. 6 similar to the symbols of the type no. 14 (see above). The height of the realistic puspikā is slightly more than one line of the folio and that of the stylised puspikā in line no. 6 is one line of the folio. Likewise, in this context, the realistic pusppikā may be interpreted as a representation of a padma ('lotus').

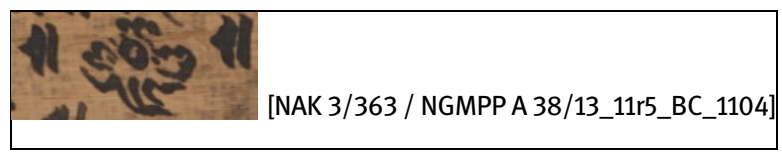

Fig. 3.5.1-VI: Realistic pușpikā after the colophon

In one Buddhist manuscript of the Śatasāhasrikā Prajñāpāramitā kept in the Royal Library, Copenhagen (Det Kongelige Bibliotek) as Nepal 175A and catalogued by Buescher (2011, 21-22, Cat. 7), one folio of which Trier (1972) presents in his appendix as plate number 111, there are two realistic pusppikās. Buescher dates the manuscript NS 548 i.e. 1428 CE. ${ }^{242}$ However, he overlooks another date mentioned in letter-numerals as NS 265 on $814 \mathrm{v} 3$. On palaeographical and other grounds, such as the time of the reigning king and so forth, this date should be that of the copying of the manuscript and not the date suggested by Buescher. ${ }^{243}$

The first realistic puspika appears after the Buddhist verse the last part of which reads 'vamvādì mahāśramanạ̣' on 814v1. The second realistic puṣpikā is followed

241 The line reads as follows kalyānakāmadhenūvivaraṇam samāptam ("[thus,] the commentary on Kalyānakāmadhenū is concluded').

242 See Buescher 2011, 21.

$243 \mathrm{Kim} 2014,2$ also suggests the original date of the manuscript to be NS 265 (1145 CE). 
on the same line by a statement recording the reign of King Narendradeva. ${ }^{244}$ From their appearance, both realistic puspikās in this manuscript exhibit a degree of similarity to the realistic pusspikās can be found in the manuscript of the Saddharmapuṇdarīkasūtra (CUL Add.2197) (see Fig. 3.5.1-V above). Once more, in this context the realistic pușpikās may be understood as representations of padmas ('lotuses').

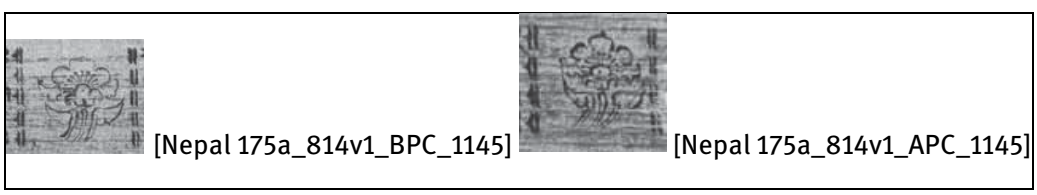

Fig. 3.5.1-VII: Realistic pușpikās before and after the post colophon (reproduced from Trier 1972, plate 111, n. 175a)

In $\mathrm{Assp}_{1}$ there are two realistic pusppikās before and after the second chapter colophon on 26v4. ${ }^{245}$ The height of both pusppikās is only two lines of the folio, although they are demarcated by three sets of double dandas. The first realistic puspika is partially highlighted in the upper part and the second one is 'fully' highlighted. In this context also both realistic puṣpikās may be interpreted as representations of padmas ('lotuses'). Examples can be seen in Fig. 3.5.1-VIII.

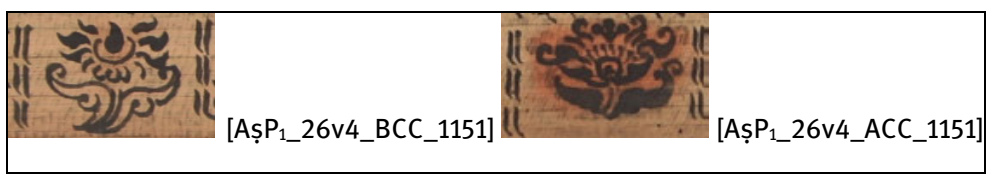

Fig. 3.5.1-VIII: Realistic pușpikās before and after the chapter colophon

244 The line reads in line nos. 1-2 as follows śrimadrājādhirājaparameśvaraparamabhațtārakaśrimannarendradevasya vija[2]yaräjye ('in the victorious kingdom of venerable Narendradeva, paramount sovereign, supreme lord, venerable king of great kings'). After the line one circle can be found between a set of double dandas. In this case the later double dandas are being used both as closing final daṇas for the circle and one of the demarcating double dandas of the first realistic pușpikā.

245 The colophon reads as follows āryāșțasāhasrikāyām prajñāpāramitāyām śakra|ఠ|parivartto nāma dvitìyah ('[thus], the second chapter, namely Śakra in the noble Perfection of Wisdom in Eight Thousand Lines is [concluded]'). 
On the use of symbols, the manuscript of the Aștasāhasrikā Prajñāparamitā (ca. $12^{\text {th }}$ c. $)^{246}$ (KL 18 / NGMPP C 103/2) exhibits unique examples. ${ }^{247}$ Before the fifth chapter colophon ${ }^{248}$ on $53 \mathrm{v} 4$ there is a drawing resembling a bird in full form and a head like that of a baby bird or snake which may be interpreted as a representation of a 'mayūra' or 'mayūrì' ('peacock' or 'peahen') and a baby peacock or peahen or snake respectively (see Fig 3.5.1-IX). ${ }^{249}$ After the chapter colophon we find a realistic puṣpikā together with some floral elements surrounded on left, right and bottom sides. Regarding form and context, the realistic puspiki here may be interpreted as a padma ('lotus'). Both elements are lightly highlighted.

246 This manuscript can possibly be dated from ca. $12^{\text {th }}$ c. on palaeographical grounds, although we find a date with NS 748 (1628 CE) on one of the folios. The folio seems to have been added later and the handwriting looks quite modern compared with the handwriting on other folios. The line reads: samvat 748 māghaśuklaḥ(!) ekādaśyān tithau ... ('the [Nepāla] era 748, on the eleventh day [of] bright fortnight of the month $\left.m \bar{a} g h a^{\prime}\right)$. Furthermore, we find in the same line: taddine jïrnnoddhāranalikhita(!) ('on that day it was written for the 'restoration' [purpose] ...'). Therefore, the date on the folio is possibly a 'restoration' date.

247 For examples and discussion of the use of further symbols, see sections 3.6.2.1.6 and 3.6.2.4.2.

248 The chapter colophon reads āryāștasāhasri||ఠ|kāyām prajñāpāramitāyām punyaparyāyaparivartto nāma pañcamah ('[thus], the fifth chapter, namely the punyaparyāya in the noble Perfection of Wisdom in Eight Thousand Lines is [concluded]').

249 A feature resembling a kind of bird can be found in KT on 68v7_ACC (see section 3.6.2.2). Furthermore, attestations of drawings of birds on the upper-margin of the folio can also be found in some manuscripts. In the manuscript of the Aștasāhasrikā Prajñāpāramitā (ca. $15^{\text {th }} / 16^{\text {th }}$ c.) (NAK 4/1637 / B 22/18) we find small birds, on 151r (two birds), 156r (one bird), 157r (one bird), 170v (one bird), 191r (one bird), 193v (one bird), 194v (three birds), 195r (one bird), 201r (two birds), 201v (two birds), 208v (one bird), 211v (one bird), 214v (two birds). All these birds clearly look like peacocks. In the manuscript of the Pañcarakșā (ca. 15 th $^{\text {th }} 16^{\text {th }}$ c.) (KL 108 / NGMPP C 11/4) small birds are drawn in the centre part of the upper-margin on 43r and 46r. The bird on 43r can be found on the top of the akșara 'pa' of patita(!) of the text portion of 'sa klāntakāyo bhūmau patita(!)' in the Mahāmāyurividyārājiñ and the bird on 46r is drawn on the top of the akșara (trā) of maitrā of 'sarvabhūteșu me maitrā(!) ye kecit prthivĩ sthitā' in the same text. In front of the beak of the bird on 43r there is a mātrā sign of ' $a u$ ' with two petal-like elements and in front of the beak of the bird on 46 there is a semicircle-like element and six 'dots' which possibly represent a chirping bird or perhaps a speaking godess in abstract terms. As both birds appear in the text part of the Mahāmāyurividyārājiñi they can probably be interpreted in this context as a representation of the godess Mahāmāyurī. 


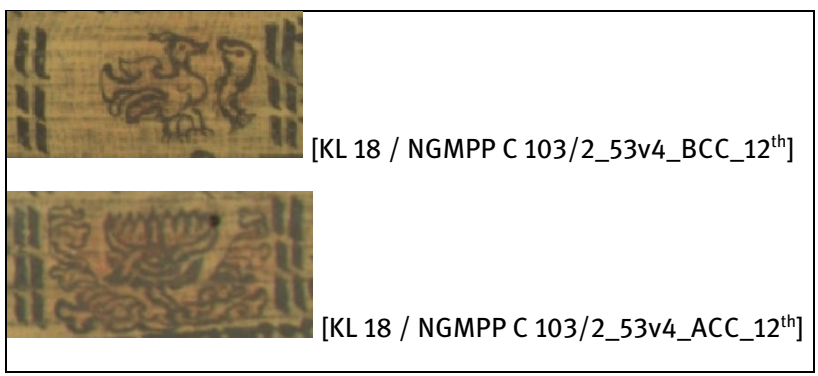

Fig. 3.5.1-IX: Bird and realistic pușpikā before and after the chapter colophon

In the manuscript of the Viṣnudharma ${ }^{250}$ (ca. $12^{\text {th }}$ c.) (NAK 4/766 / NGMPP A 10/1) there are two realistic pușpikās (see Fig. 3.5.1-X). The first appears before the first chapter colophon on $3 \mathrm{r}^{2}{ }^{251}$ Following that is a stylised puspika similar to the type no. 14. The second realistic puṣpikā appears after the speaker indication (prahlāda uvāca, 'Prahlāda said') on the right side on 98v6 (last line). The speaker indication is preceeded by a chapter colophon demarcated by the stylised pusppikās.

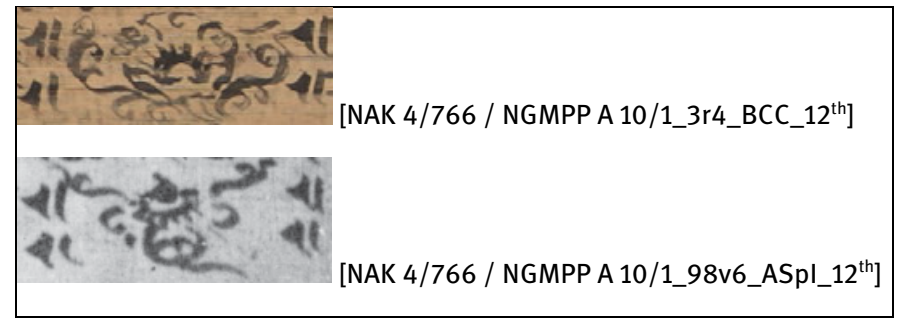

Fig. 3.5.1-X: Realistic pușpikās before the chapter colophon and after the speaker indication

Four realistic pușpikās are in the manuscript of the Nitisārapañjikā (Jayamangalā) (KL 77 / NGMPP C 6/13) on 45v3, 81r2, 83v1. The realistic puṣpikā on $45 \mathrm{v}$ has been drawn after the $8^{\text {th }}$ chapter colophon. ${ }^{252}$ On $81 \mathrm{v} 2$ the realistic puspiki $\bar{a}$ appears before one of the chapter colophons. The right side of the folio

250 See Grünendahl 1983, 15-16 with siglum N7.

251 The chapter colophon reads iti vidharmopadeśe(!) prathamo dhyāyah ('thus, the first chapter in the instruction of the Vi[șnu]dharma [is concluded]).

252 It reads nītisārapañjikāyām jayamañgalāyām aștamah sargaḥ ("[thus], the eighth canto in the Jayamañgalā in the Nìtisārapañjikā [is concluded]). 
is broken, therefore, only a part of the chapter colophon has been preserved..$^{253}$ The realistic puspikās on 83v1 appear before and after the $17^{\text {th }}$ chapter colophon..$^{254}$ The height of all realistic puspikikas is two (on 81r2, 83v1) to three lines (on $45 \mathrm{v} 3$ ) of the folio. In comparison to other realistic puspikās in this manuscript the second (on 81r2_BCC) and the last (on 83v1_ACC) pusppikās resemble, to a degree, fully-fledged padmas ('lotuses') and the other two realistic puṣpikās (on 45v3_ACC, 83v1_BCC) look like lotuses developing towards their fullyfledged state. Examples of pusppikās can be seen in Fig. 3.5.1-XI.

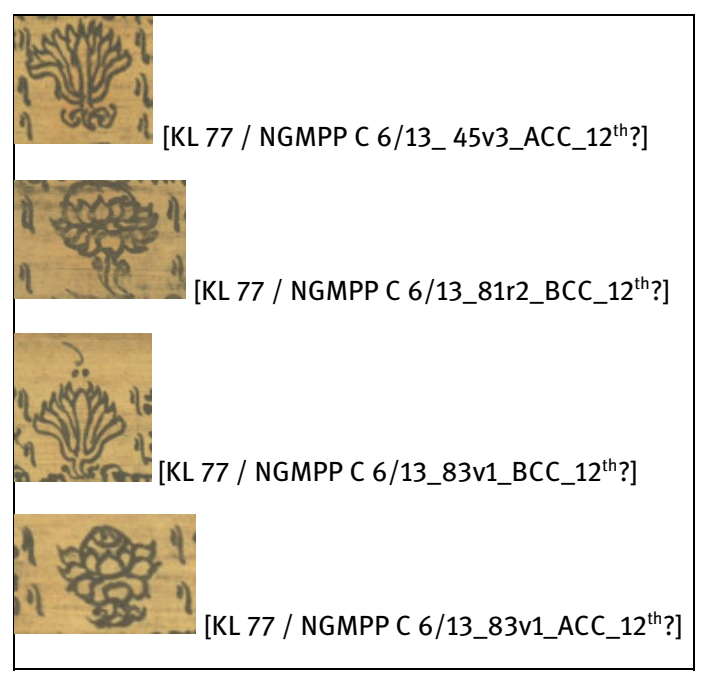

Fig. 3.5.1-XI: Realistic pușpikās before and after the chapter colophons

One realistic puspiki $\bar{a}$ appears in the manuscript of the Antarvyāptisamarthana ${ }^{255}$ (NAK 3/364 / NGMPP B 23/34) before the colophon on $6 r 7^{256}$ and one stylised

253 The preserved part of the colophon reads nitisārapañjikāyā̃n jayamanigalāya(!)/// ('[thus, ... in the] Jayamañgalā in the Nìtisārapañjikā [is concluded]).

254 The line reads nitisārapañjikāyām jayamañgalāyām saptadaśaḥ sargạ̣ ('[thus], the seventeenth canto in the Jayamañgalā in the Nitisārapañjikā [is concluded]).

255 See Shastri 1915, Vol. II, 43. This manuscript was used by Kajiyama 1999, ix with siglum M for the edition.

256 The colophon reads antarvyāptisamarthanam samāptam iti ('thus, the Establishment of Internal Pervasion is concluded'). Here I follow Kajiyama 1990, 130 for the English translation of the title of the work. 
puspiki can be found after the colophon. The stylised pusppikā is followed by the author line ${ }^{257}$ and the line is again followed by another stylised puṣpikā (like type no. 16). The height of the realistic puspikā is slightly more than one line of the folio. Likewise the realistic puspikā may be understood as a representation of a padma ('lotus').

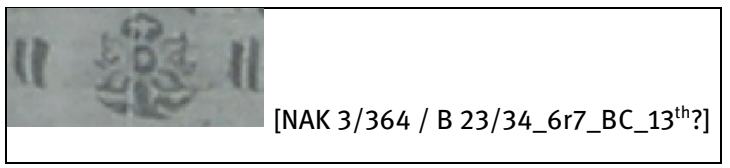

Fig. 3.5.1-XII: Realistic puṣpikā before the colophon

As in the case of stylised puṣpikās, realistic puṣpikās usually appear at the end of chapters and texts and once after the speaker indication thus marking the end of major text sections. In comparison to other symbols even within the same manuscript, they are very decorative and enhance the aesthetic value of the whole manuscript. Regarding realistic puṣpikās appearing in Buddhist manuscripts the 'realistic' lotuses may be interpreted as representation of prajña ('awakening aspect of wisdom'). ${ }^{258}$ Having found such realistic puṣpikās in many Nepalese manuscripts, ${ }^{259}$ I am inclined to postulate that such features could be peculiar to manuscripts produced in this area.

\subsubsection{Symbols in East Indian manuscripts}

In manuscripts from East India various kinds of stylised pușpikās are also found. Among them a sub-category can be singled out that includes a siddham symbol, used at the end of chapters, sections or whole texts. Such a symbol is found in at least six East Indian manuscripts, five possibly originating from Vikramaśīla and the other $(\mathrm{AA} \overline{\mathrm{A}})$ from a nearby area. The siddham symbol has already been introduced above (see section 3.4) as type no. 45. The shape of this symbol is identical to the character ' $t$ ' (in 'Old Bengali' script), which is the script used in the manu-

257 It reads kṛtir iyam ratnākaraśāntipādānām iti ('thus, this work [is] of venerable Ratnākaraśānti').

258 On this topic, see also section 3.6.2.1.2 below.

259 Realistic puṣpikās with leaves and buds resembling lotuses can also be found in some Nepalese Inscriptions, see e.g. Indraji 1885, Nos. 5 and 15; and Sarkar/Pande 1999, 89, Fig. 26. 
scripts. An example of the character ' $t$ ' can be seen in Fig. 3.5.2-I and compared with Fig. 3.4-XLV above.

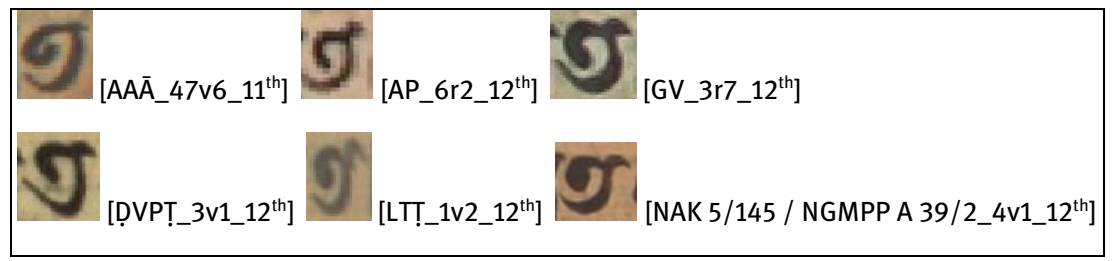

Fig. 3.5.2-I: ' $t$ ' similar to symbols in Fig. 3.4-XLV

In the previous sections we have seen close similarities in terms of layout. Symbols in many manuscripts of this group and just above feature the writing style of ' $t$ ' (without vowel) and are similar to one of the types of siddham symbols (for symbols, see section 3.4, type no. 45). In this section more observations on palaeographical evidence in the selected manuscripts of this group are presented. Aside from one manuscript (HTṬ in which Vikramaśīla has been mentioned as the copying place), ${ }^{260}$ all manuscripts of this group contain no information on copying place or date. Therefore, it is always helpful to gather as much as information and examples of the different features they contain to enable a better understanding of their existence and group them in a more reliable manner. For this reason, some akșaras, single dandas, double dandas and visargas from the 'core' corpus of the East Indian manuscript group have been collected and analysed as well as another manuscript out of the 'core' corpus: the manuscript of the Pāramitāsamāsa (NAK 5/145 / NGMPP A 39/2) (henceforth: NAK 5/145) which could also belong to this group (on the basis of layout, symbol and paleographical evidence). For the akșaras $a, i, u, k a, k h a, g a, g h a, c a, j a, t ̦ a, n a, t a$, tha, da, dha, na, pa, bha, ma, ya, ra, la, va, sa, șa, sa, ha have been selected for each manuscript (except for the CPN from which I have selected two akșaras of $i$ ). In the following the akșaras are compared for their similarities or differences in writing style.

Akșaras $a$ of GV, HAP, LTṬ, STṬ, DVPTT, HP are identical whereas $a$ of AP, CPN and NAK 5/145 have a near similar form. Furthermore, $a$ of AAA and AT exhibit some similarities in the writing. Both contain a kind of curved line in the upper part. I of GV, HAP, LTT, STT, DVPT look similar but the $i$ of AP and one of

260 Since PR is dated and written in another script, I have excluded it for the occasion of the palaeographical observation here. 
the is of CPN exhibit close similarities in the writing style. However, the second $i$ of CPN, HP and NAK 5/145 are to some extent identical. $U$ of GV, HAP, LTT, STT, DVPT, CPN and HP share also similarities. Akșaras $u$ of AAĀ and AT look somewhat similar.

$K a$ of GV, HAP, LTT, STṬ, DVPT, HP, NAK 5/145 look nearly identical. But $k a$ of AAĀ and AT are near identical in form. Kha of GV, HAP, STT, DVPT, AP and CPN exhibit many similarities. Kha of LTT, HP and NAK 5/145 look similar. Ga of GV, HAP, LTT, STṬ, DVPT, AP, CPN, HP and NAK 5/145 look almost identical. However, $g a$ of AAĀ, HTT and AT share some similarities in writing. Gha of GV, HAP, LTT, DVPT and AP share many similarities in writing. However, gha of HP and NAK 5/145 look nearly identical. Gha of HTT and AT are to some extent similar.

Ca of GV, HAP, LTT, STT and DVPT exhibit many similarities. Ca of AP and CPN look nearly similar in writing style. Furthermore, $c a$ of AAĀ, HTT, AT and NAK 5/145 are similar if we leave the upper curved line of $c a$ of HTT, AAĀ. Ja of GV, HAP, LTT, STṬ and ḌPTT are nearly identical. However, $j a$ of AAĀ, AP, CPN, AT and NAK 5/145 look to some extent similar.

Ța of GV, HAP, LTT, STṬ, DVPT, AP, CPN, HP, NAK 5/145 share close similarities in writing. Na of GV, HAP, LTT, STT, DVPT, AP, CPN, HP and NAK 5/145 exhibit many similarities. But ṇa of HTT and AT look nearly identical.

Ta of GV, HAP, LTT, STT, DVPT, AP, CPN, HP and NAK 5/145 are nearly identical. Whereas $t a$ of AAĀ, HTT and AT contain a kind of curved stroke in the upper part. Tha of GV, HAP, LTT, STṬ, DVPT, AP, CPN and NAK 5/145 share to some extent similarities in writing style. However, tha of HP, HTT and AT exhibit slight similarities in form. Da of GV, HAP, LTT, STT, DVPT, AP, CPN and NAK 5/145 look identical. Dha of GV, HAP, STT, DVPT, AP, CPN and NAK 5/145 share many similarities in writing. Dha of AAĀ, AP look to some extent comparable in form. Furthermore, dha of LTT and CPN share to some extent similar features. $\mathrm{Na}$ of GV, HAP, LTT, STT, DVPT, AP, CPN and NAK 5/145 look similar. However, na of AAA $\bar{A}$, HTT and AT share some similar features if we see the writing style of the upper line of the akșaras.

$P a$ of GV, HAP, LTṬ, STṬ, DVPTT, AP, CPN and NAK 5/145 look identical. Pa of HAP, HP share nearly similar writing style. However, $p a$ of AAĀ, HTT and AT look rather similar. The upper line of the akșara is a bit curved and touches the (right side of) vertical stroke a bit in the lower part from the top. Bha of GV, HAP, LTT, STT, DVPT, AP, CPN, HP and NAK 5/145 look somewhat similar. Bha of AAĀ, HTT and AT share to some extent similar features. For instance, their upper line is slightly curved. $M a$ of GV, HAP, LTT, STT, DVPT, AP, CPN, HP and NAK 5/145 look quite similar. However, ma of AAĀ, HTT and AT share some 
matching features. For instance, the upper line of them is slightly curved and touches a bit of lower part of the vertical stroke from the top.

Ya of GV, HAP, LTT, STT, DVPT, AP, CPN and NAK 5/145 are nearly similar in form. Whereas ya of AAA $\bar{A}$, HTT and AT look to some extent similar in writing style. $R a$ of GV, HAP, LTT, STT, DVPT, AP, CPN, HP and NAK 5/145 exhibit close similarities to each other. $R a$ of $\mathrm{AAA}$ and AT share identical features. $L a$ of GV, HAP, LTT, STT, DVPT, AP, CPN and NAK 5/145 look similar in many cases. Va of GV, HAP, LTT, STT, DVPT, AP, CPN and NAK 5/145 exhibit many similarities in form. However, $v a$ of AAĀ, HTT and AT with their upper line look to some extent identical.

Śa of GV, HAP, LTT, STT, DVPT, AP, CPN, HP and NAK 5/145 are almost similar in form. But śa of HTT and AT look similar in writing style. The upper part of the right stroke is slightly curved. Șa of GV, HAP, LTT, STT, DVPT, AP, CPN and NAK 5/145 exhibit many similarities with each other. Whereas șa of AAA, HTT and AT share many identical features. Their upper line is slightly bent and the right stroke is longer. $\mathrm{Sa}$ of GV, HAP, LTT, STT, DVPT, AP, CPN, HP and NAK 5/145 are nearly identical. However, $s a$ of AAA $\bar{A}$, HTT and AT share many similarities in writing. The upper line of them is curved. Ha of GV, HAP, LTT, STT, DVPT, AP, CPN and NAK 5/145 look rather identical. Ha of AAA share a few similarities, if we look at the writing style of the upper line.

The visarga sign of GV, HAP, LTT, STT, DVPT, AP and CPN are also identical. They are written with two circles. The upper circle contains a 'dot' or small curved-like 'line' on the upper right side. The visarga of AAA, HP, HTT and NAK $5 / 145$ resembles the modern number ' 8 '. However, the visarga of AAA $\bar{A}, \mathrm{HP}$ and NAK 5/145 look to some extent similar in form.

The single and double daṇdas of GV, HAP, LTṬ, STT , ḌPT, CPN and HP are a bit similar. In the case of AAĀ the single danda and the first danda of the double danda contain a kind of small dot-like element on the left side in the centre of the stroke.

An important feature in this group can also be noticed in the writing of some akșaras. If we look closely at some of the akșaras in some manuscripts, a kind of dot-like element can be found on the top of the upper line of the aksaras e.g. on the top of the upper line of akșara na of GV, HAP, STT, AP; on the top of the upper line of $v a$ of GV, HAP, LTT, STT, DVPT, CPN; on the top of the upper line of $r a$ of GV, LTT, DVPT, CPN, AP.

Furthermore, a majority of manuscripts of this group also contain an identical symbol that appears before the invocations at the beginning of the manuscripts (GV, HAP, LTT, STṬ, DVPTT, AP, CPN and NAK 5/145) (see section 3.4, type no. 43). 


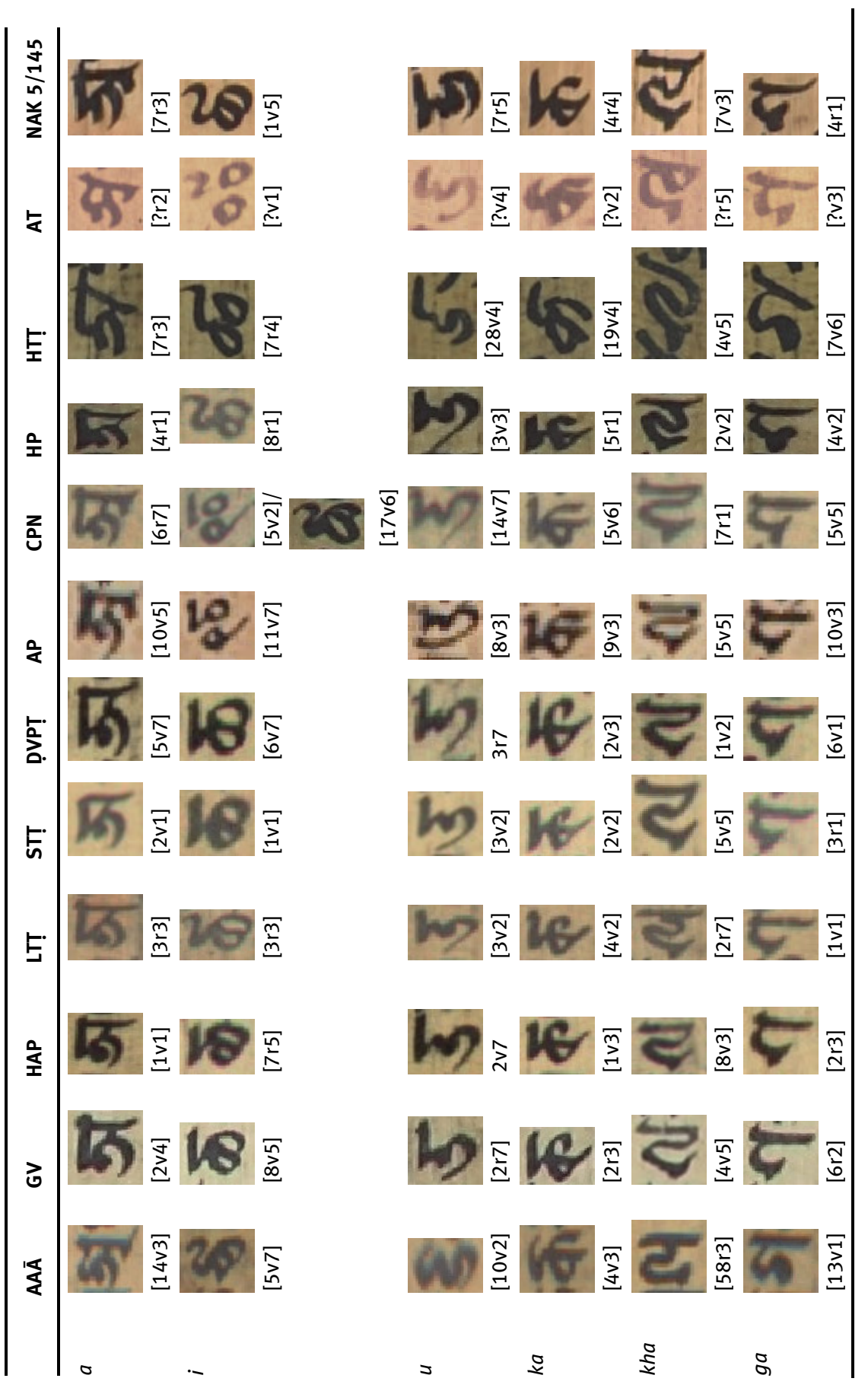




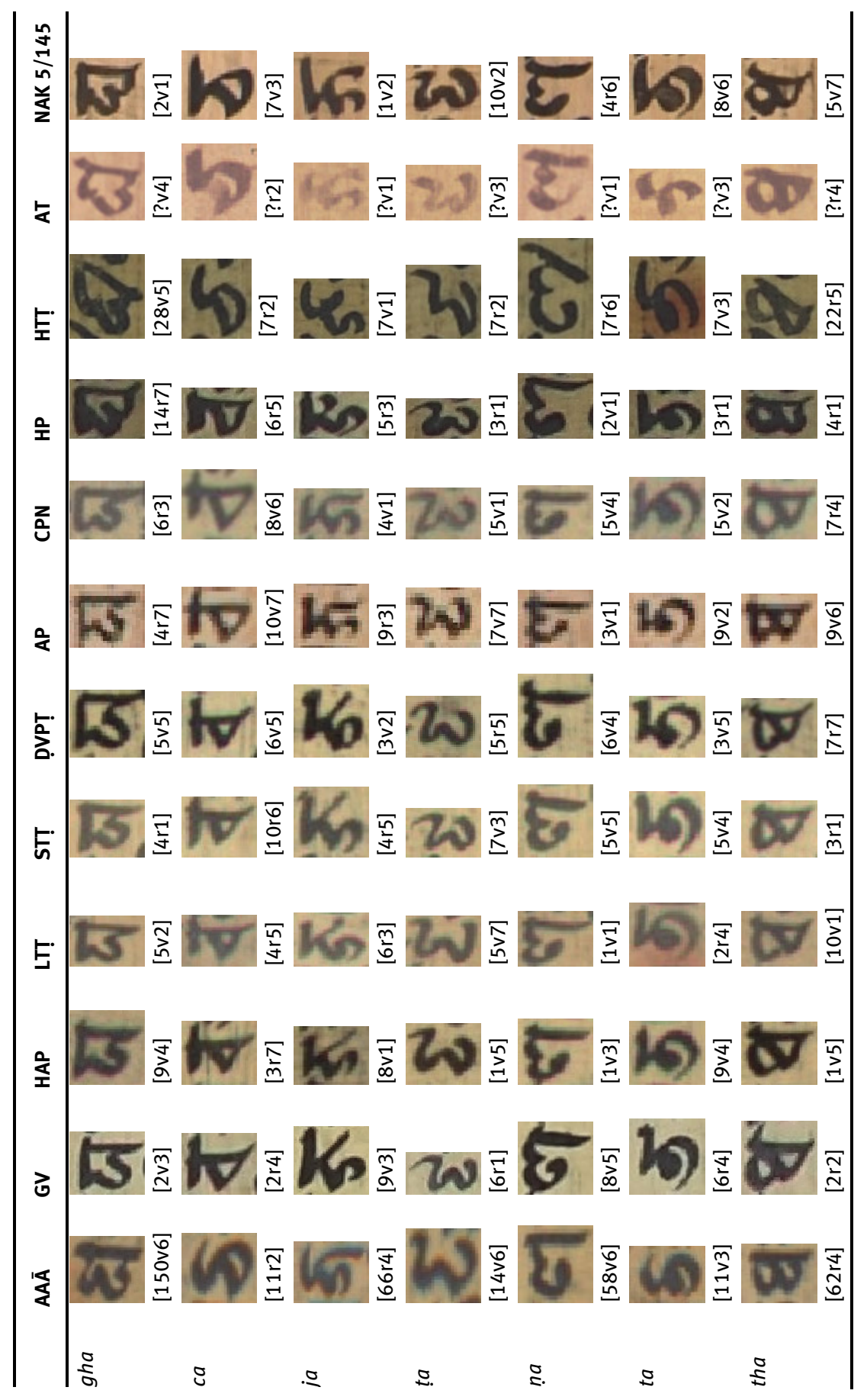




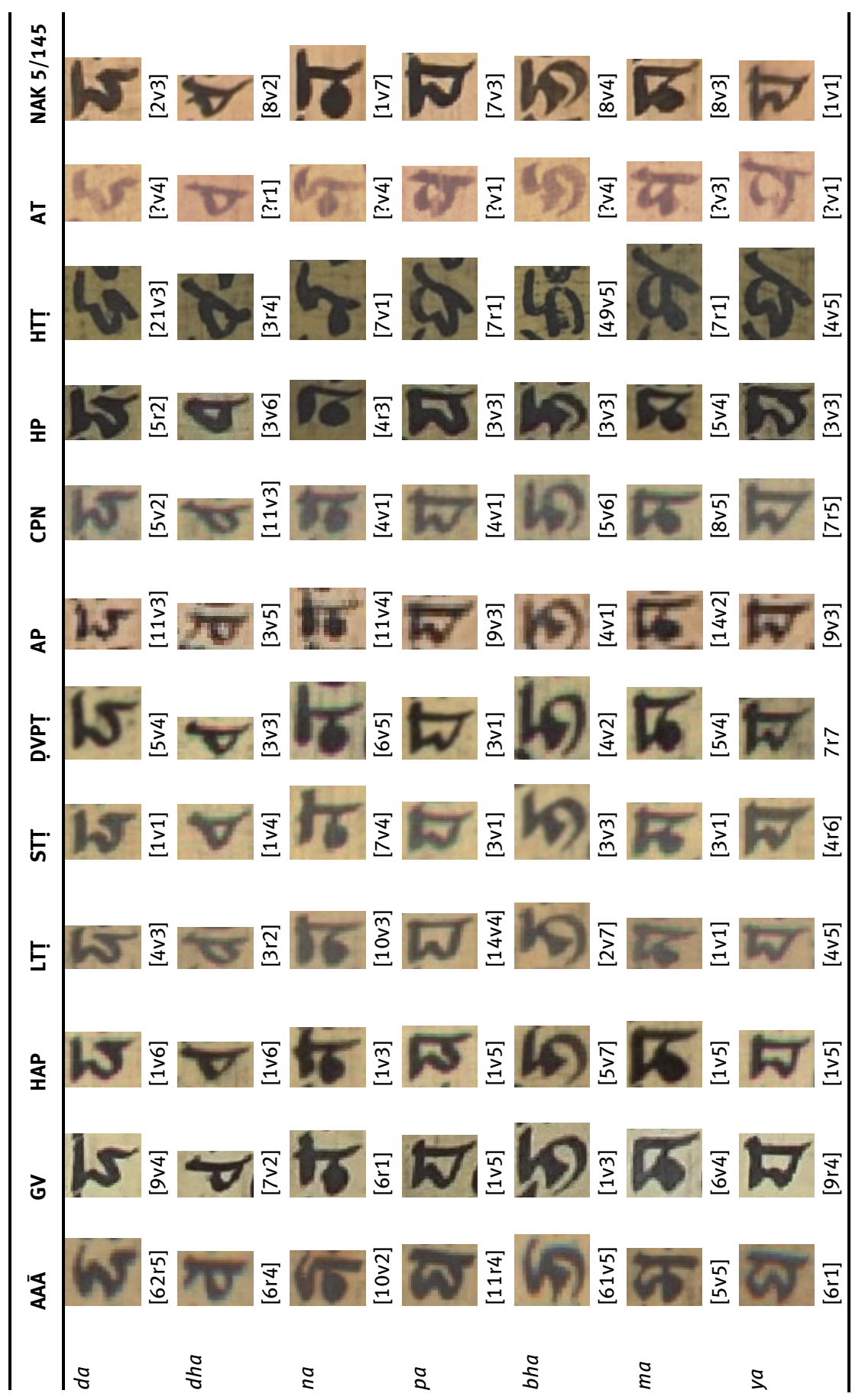




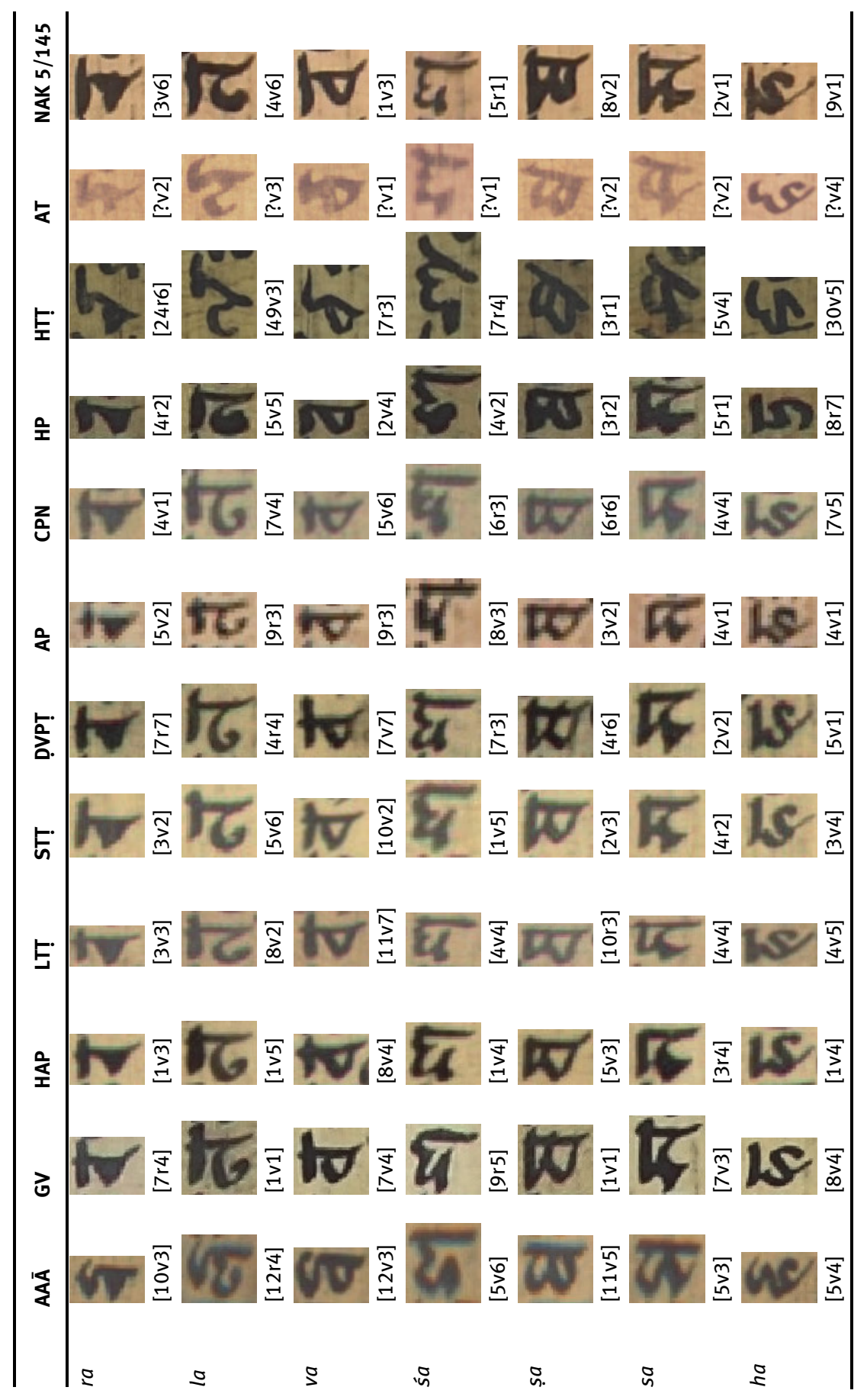




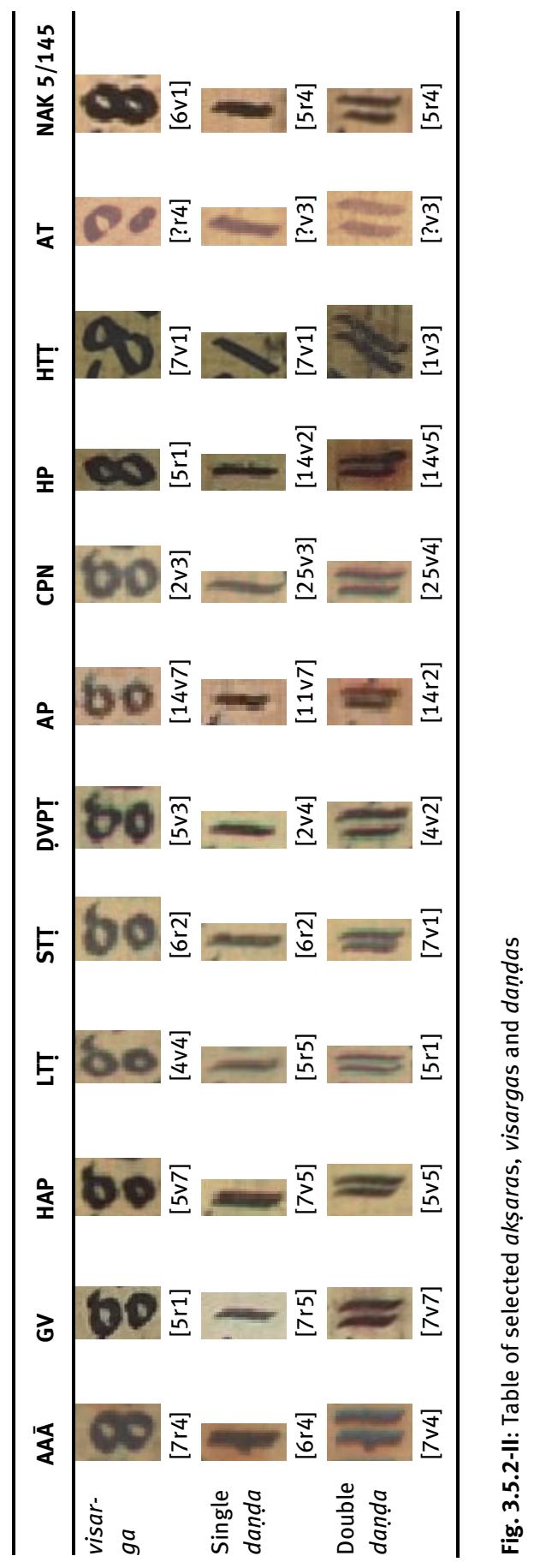




\subsubsection{Symbols in West Indian manuscripts}

In West Indian manuscripts a 'cha' symbol can often be found at the end of smaller text units (such as simple sentences, paragraphs etc.), at the end of chapters or at the end of whole texts etc. (see Fig. 3.4-XLVII above). A few scholars have already written about this symbol, without however reaching a final interpretation of it (see 3.4, Fig. 3.4-XLVII and footnote 221).

Another variety of symbols has emerged from my analysis of West Indian manuscripts, in which the already known 'cha' symbol is drawn together with extra surrounding elements. I categorise this type also as a stylised puspikā. The 'cha'-like element is surrounded by $u$-akșara-like or similar components on the left, right and bottom with or without a 'tail' added to them (see Figs. 3.5.3-I to 3.5.3-III below). ${ }^{261}$ The upper part of the symbols often appears open (with a few exceptions). One may argue that a fourth $u$-akșara-like part is not drawn above the symbol as its space is already taken up by the text line. Another variety of this stylised puṣpikā symbol contains a circle or a dot with a 'stroke' or 'tail' in the centre, instead of the 'cha'-like element. Hereafter, I present some examples in possible chronological order.

In TSPV this type of symbols can be found at the end of chapters on 180r8, $191 v 6$ and at the end of the text on 313v2. ${ }^{262}$ One example can be seen in Fig. 3.5.3-I.

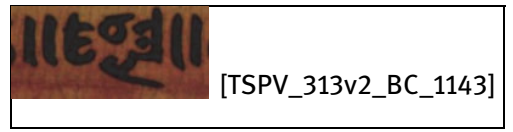

Fig. 3.5.3-I: Symbol

In HVM this type of symbol can be found at least 28 times at the end of the chapters as well as at the end of the whole text. The symbol contains a 'cha'-like element in the centre. One of the examples of the symbol can be seen in Fig. 3.5.3-II.

261 Also near similar symbols are in the manuscript of the Kalpalatāviveka (Kalpapallavaśeșa) (VS 1205/ 1148 CE) (Jinabhadrasūri Grantha Bhaṇ̣āra, Jaisalmer, no. 317) on 389r3-4_A/BCC, $\mathrm{AC}$ ); in the manuscript of the Upadeśapadaprakaraṇalaghuțīka (VS 1212 / 1155 CE) (Jinabhadrasūri Grantha Bhaṇ̣̄āra, Jaisalmer, no. 214/1) on 192r4_AC and 192r5_AB.); see Kapadia 1936, Plate VI, a similar symbol can be found together with the foliation ' 60 '.

262 See section 3.6.2.4.1 below. 


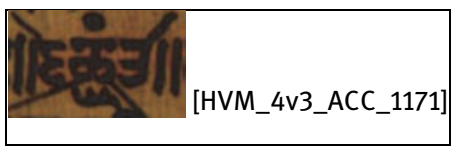

Fig. 3.5.3-II: Symbol

In PV the symbol can be found twice on 10v6 and 15v1. Both symbols can be found at the end of the chapters. The symbol contains a circle in the centre (with a stroke added horizontally on top of it). In Fig. 3.5.3-III, example of the symbol can be seen.

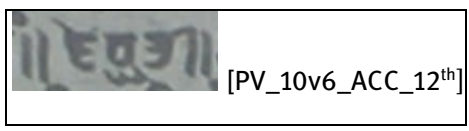

Fig. 3.5.3-III: Symbol

It can be assumed that the stylised puspiki $\bar{a}$ with the 'cha' and its simpler variations are peculiar features characterising the manuscripts from West India.

\subsection{Symbols and their functions in manuscripts}

As already mentioned in the previous sections (see sections 3.1 and 3.4), in most of the manuscripts of this corpus symbols appear at the end of chapters or texts. Occasionally, they are interspersed in the text to emphasise topics of particular relevance. Such symbols can be found in other parts of the manuscript. They are to be found on the margins of the folio, for instance, sometimes accompanying the foliation numbers, and around the string-holes.

Until now, very little secondary literature has addressed the issue of use of symbols in manuscripts and then only marginally, without providing a thorough analysis of their shapes, functions and possible meanings. Symbols not only demarcate texts and their sections, but may well have more than one function and can be closely related to the contents, performative usages of the text etc.

To improve our understanding of the role that some of (the florally stylised) symbols play in manuscripts, one may turn to Plofker's interpretation of the import of diagrams. While discussing diagrams appearing in astronomical paper manuscripts Plofker $(2009,5)$ writes: 
[...] they are occasional visual reinforcements for verbal explanations and rules, and they are generally roughly schematic rather than precisely traced.

Hereafter, I have categorised symbols according to their position on the page, shape, etc. mainly into two groups: decorative-only symbols (3.6.1) and structural and decorative symbols (3.6.2).

\subsubsection{Decorative-only symbols}

Decorative symbols are solely of aesthetic value. They serve no other specific function and are not linked to the tradition of the text found in the manuscript, like for instance some of the symbols drawn around the string-holes. ${ }^{263}$

Representation of symbols around the string-hole can be found in almost all manuscripts from Western India selected for my corpus and also, occasionally, in a few Nepalese manuscripts (see Figs. 3.6.1-VIII and 3.6.1-IX below). However, the individual shape of the symbols in both groups varies to a great degree.

It is not clear when such type of decorative elements started to appear around string-holes in West Indian manuscripts. The oldest available example is found in a Jaina manuscript containing a copy of the Upamitibhavaprapañ $\bar{a}$ Kathā (Bhandarkar Oriental Research Institute, Pune, Acc. no. 7a-b/1880-81) dated 906 CE. ${ }^{264}$ Many later examples from the same area (see TSa, TSPV, HVM, $\mathrm{PV}, \mathrm{JKS} / \mathrm{C}$, TUS and BCV in my corpus) ${ }^{265}$ and largely from the same religious

263 I am not claiming that all symbols appearing around string-holes do not have any further meanings or affiliation to the contents or tradition to which the manuscripts belong. There are also cases in which we find realistic or florally stylised symbols around string-holes in manuscripts which show a close affiliation to the specific tradition. Some of them are even clear representations of ritual emblems (see section 3.6.2.6.1 below).

264 See Gopalakrishnan 2007, 30. Should the suggested date of the manuscript production by Gopalakrishnan be reliable, examples of the occurrences of such symbols in this manuscript may be the oldest of the area.

265 Stylised puspikās can be seen around string-holes in the manuscript of the Jayadevachandạ̣ Śāstra (VS 1190 / 1133 CE) (Jinabhadrasūri Grantha Bhaṇḍāa, Jaisalmer, no. 314/1); in the manuscript of the Praśnottararatnamālikā (VS 1196 / 1139 CE) (Jinabhadrasūir Grantha Bhaṇūāra, Jaisalmer, no. 171/10); in the manuscript of the Șaḍāvaśyakasūtravṛtti (VS 1298 / 1241 CE) (Jinabhadrasūri Grantha Bhaṇ̣āra, Jaisalmer, no. 136/1); in the manuscript of the Sūtrakṛtāngasūtravṛtti (VS 1200 / 1143 CE) (Jinabhadrasūri Grantha Bhaṇḍāra, Jaisalmer, no. 4); in the manuscript of the Kalpalatāviveka (Kalpapallavaśeșa) (VS 1205 / 1148 CE) (Jinabhadrasūri Grantha Bhaṇạara, Jaisalmer, no. 317); in the manuscript of the Praśnottararatnamālikā (VS 1210 / 1153 CE) (Jinabhadrasūri Grantha Bhaṇdāra, Jaisalmer, no. 154/13); in the manuscript of the Upadeśapadaprakaraṇalaghuțîkā (VS 1212 / 1155 CE) (Jinabhadrasūri 
milieu, display similar decorative elements. ${ }^{266}$ These were also adopted in manuscripts containing texts belonging to other traditions (Hindu and Buddhist), but were never as consistently employed as the manuscripts produced by Jainas of West India. ${ }^{267}$

In TSa a string-hole can be found slightly more than one third space away from the left edge of the folio. Around each string-hole we find a decorative symbol made of four petals. Each petal is made by joining two almost semicircular elements on the side. ${ }^{268}$ Furthermore, one may expect a circle in the centre part of the symbol. In this case, the circle has probably been replaced by the string-hole. Examples can be seen in Fig. 3.6.1-I.

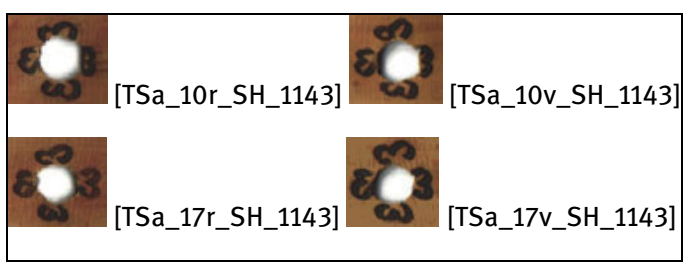

Fig. 3.6.1-I: Symbols around string-holes

In TSPV, two string-holes can be found on each folio. Symbols appear around both string-holes on the folio. At least three types of symbol can be found in the manuscript (regarding these variants see section 3.9.4 below). In these cases too, the string-hole replaces the circle at the centre part of the symbols in the manuscript. In Fig. 3.5.3-II, examples of selected symbols can be seen.

Grantha Bhaṇdāra, Jaisalmer, no. 214/1); in the manuscript of the Savaga Padikkamana Sutta cunni (Sanskrit: Śrāvakapratikramasūtracūrṇi) (VS 1317 / 1260 CE) (Museum of Fine Arts, Boston. Denman Waldo Ross Collection, 30.1.1-229) almost on all folios, see also for symbols, the folios 1v-2r, 285v of this manuscript that are presented by Kim 2015, 68 as Fig. 14; in the manuscript of the Sthānāngasūtravṛtti (VS 1300 / 1295 CE) (Jinabhadrasūri Grantha Bhaṇ̣āra, Jaisalmer, no. 6); in the manuscript of the Praśnavyākaraṇadaśāngasūtravṛtti (VS 1300 / 1295 CE) (Jinabhadrasūri Grantha Bhạ̣ūāra, Jaisalmer, no. 23/3).

266 In many later Jaina paper manuscripts various kinds of symbols or elements are found at the centre or almost at the centre of the page e.g. see the manuscript containing texts of the Kalpasūtra and the Kālakācārya (1404 CE) (Royal Asiatic Society, Tod MS 34). This way of using of symbols or other elements is probably an imitation of the practise of the usage of symbols and other items often to be found around string-holes in palm-leaf manuscripts.

267 See Weber 1891, XV; Tripāṭhī 1975, 25.

268 See section 3.4, type no. 12, Fig. 3.4-XII above. 


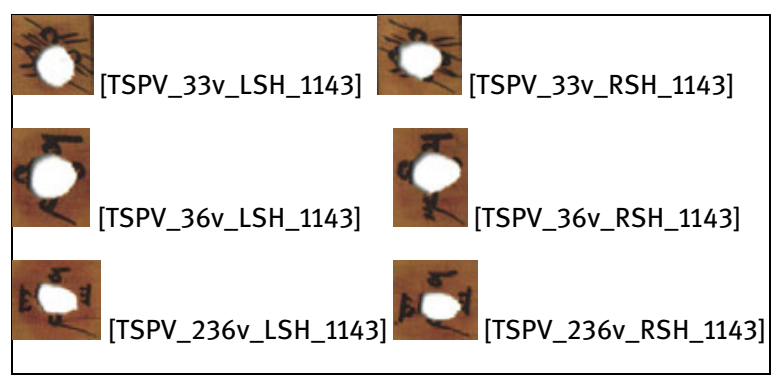

Fig. 3.6.1-II: Symbols around string-holes

In HVM, there are two string-holes on each folio. On both sides symbols can be found on all folios, except on those folios where the holes have become bigger and therefore, symbols around them have become damaged or are partially or entirely lost and their shape can no longer be seen properly. Almost only one type of symbols appears around the string-holes: it contains four lines and four semi-circular-like petals facing outside. ${ }^{269}$ The examples of selected symbols can be seen in Fig. 3.5.3-III.

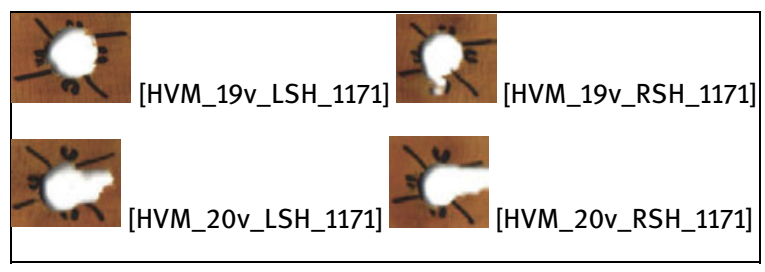

Fig. 3.6.1-III: Symbols around string-holes

In PV, one string-hole appears slightly more than one third space away from the left edge of the folio. Symbols can be found around the string-hole on each folio (with some exceptions such as on $1 \mathrm{r}, 144 \mathrm{v}$ and on a few very last folios). Only one type of symbol appears in the manuscript. This means all symbols contain four semi-circular-like petals and four sets of double lines. Examples of symbol can be seen in Fig. 3.6.1-IV.

269 This type of symbol has been discussed above in section 3.4, see type no. 10, Fig. 3.4-X. 


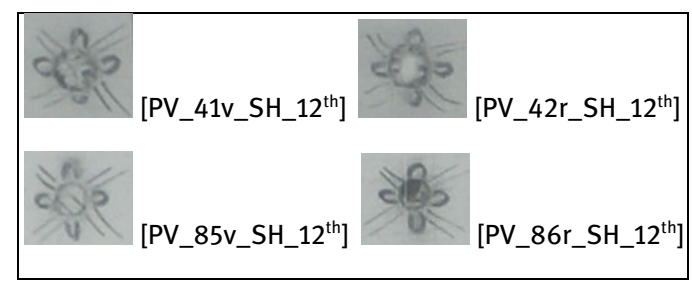

Fig. 3.6.1-IV: Symbols around string-holes

Furthermore, in JKS/C, one string-hole can be found slightly more than one third space away from the left edge of the folio. Symbols can be found around the string-hole on each folio. All symbols share an identical shape. This means all symbols contain four semi-circular petals and four lines. Examples of selected symbols can be seen in Fig. 3.6.1-V. ${ }^{270}$

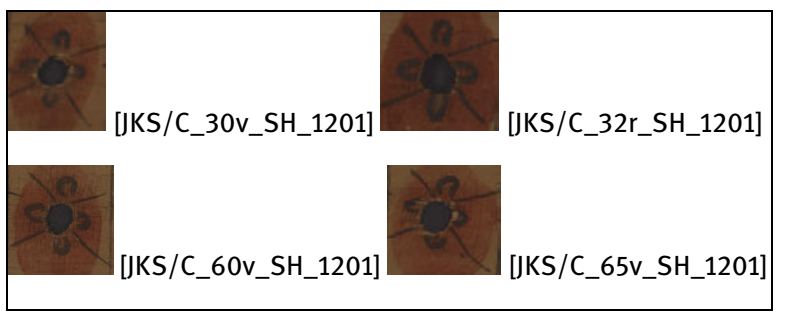

Fig. 3.6.1-V: Symbols around string-holes

In TUS, there is one string-hole slightly more than one third space away from the left edge of the folio. Symbols appear around the string-hole on each folio. Two types of symbol can be found around the string-holes in the manuscript, one containing four semi-circular petals and four lines and other one containing only four semi-circular petals whose lower petal appears with a tail added to it (regarding these variants see section 3.9.5 below). The examples of selected symbols can be seen in Fig. 3.6.1-VI.

270 Similar symbols can be found together with the foliation, see Kapadia 1936, Plates V-VI. 


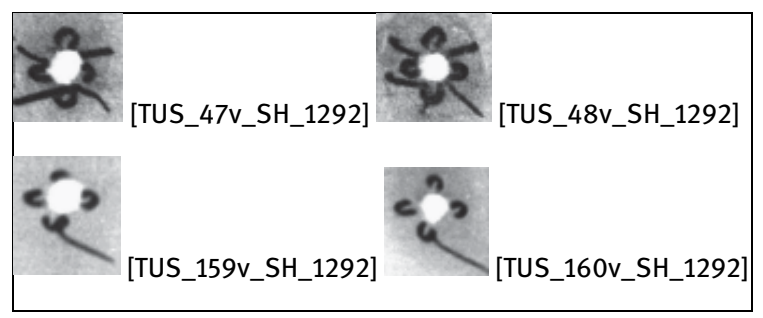

Fig. 3.6.1-VI: Symbols around string-holes

In $\mathrm{BCV}$, there is one string-hole on the folio slightly more than one third space away from the left edge of the folio. Symbols appear around the string-hole on each folio. All symbols share an identical shape. That means symbol contains four almost semi-circular petals and four lines. The examples of selected symbols can be seen in Fig. 3.6.1-VII.

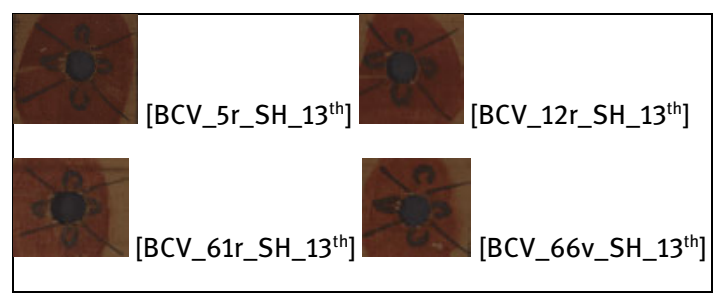

Fig. 3.6.1-VII: Symbols around string-holes

In the Nepalese manuscript KV/UVDh the folio has two string-holes. Symbols appear around both string-holes on all folios (with a few exceptions, on 1v, 44r, last folio verso where one cannot find any symbols). At least five types of symbols appear in the manuscript. In comparison to the symbols found in West Indian manuscripts, the symbols of this manuscript are drawn in a more sophisticated way. Furthermore, some symbols around the string-holes (e.g. symbols in the first and second rows in Fig. 3.6.1-VIII) and some of the symbols which appear at the end of the particular sections have an almost identical shape. This indicates that symbols at the end of smaller text units and around the stringholes have probably been drawn by the same scribe. Examples of selected symbols can be seen in Fig. 3.6.1-VIII. 


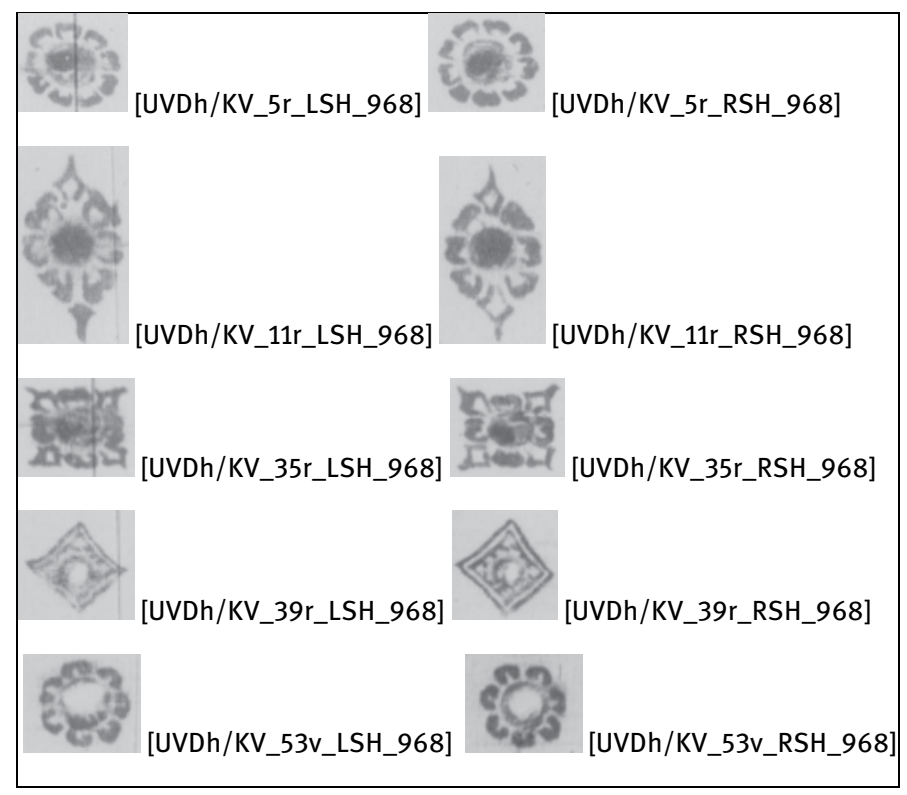

Fig. 3.6.1-VIII: Symbols around string-holes

In $\mathrm{HV}_{2}$, two string-holes can be found on the folio. Symbols appear around both string-holes only on 53v, 68r, 204v and 310r. Furthermore, symbols around the string-holes and most of the symbols that appear at the end of the chapters are identical. ${ }^{271}$ This indicates that symbols at the end of the chapters and around the string-holes may have been drawn by the same scribe in the manuscript. Examples of selected symbols can be seen in Fig. 3.5.3-IX.

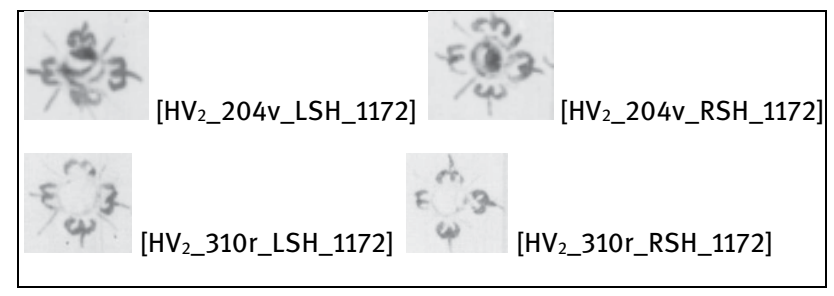

Fig. 3.6.1-IX: Symbols around string-holes

271 See type no. 16 in Fig. 3.4-XVI above. 


\subsubsection{Preliminary conclusions on decorative-only symbols}

All the Western Indian manuscripts that I have used in the course of my study contain symbols around string-holes (TSa, TSPV, HVM, PV, JKS/C, TUS and BCV). ${ }^{272}$ To some extent such symbols share nearly the same or a similar shape. Thus there are symbols containing four almost semi-circular petals and four lines around the string-holes (e.g. JKS/C, TUS and BCV). Minor variations of this pattern can also be found. For instance, symbols in PV contain four petals and four sets of double lines, whereas symbols in TSa have petals that appear to be made by joining two almost semi-circular elements on the side.

This phenomenon has not only been found in manuscripts containing texts of a specific genre (Jaina religious treatises), but from a variety of them (e.g. kāvya). However, it can be argued that the latter category of manuscripts was produced in a Jaina milieu, in other words by Jaina scribes most likely for a Jaina readership.

A symbol around the string-hole is to be found in only two Nepalese manuscripts of the 'core' corpus. ${ }^{273}$ One of them (KV/UVDh) contains symbols around string-holes on almost all folios. Even within the same manuscript, symbols appear in different shapes and are beautifully drawn (see examples of selected symbol

272 As pointed out above, also in the manuscript of Upamitibhavaprapañca $\bar{a}$ Kathē (Bhandarkar Oriental Research Institute, Pune, Acc. no. 7a-b/1880-81) e.g. on some folios presented by Gopalakrishnan 2007, 30; in the manuscript of the Jayadevachandah Śāstra (VS 1190 / 1133 CE) (Jinabhadrasūri Grantha Bhaṇ̣āra, Jaisalmer, no. 314/1); in the manuscript of the Praśnottararatnamālikā (VS 1196 / 1139 CE) (Jinabhadrasūri Grantha Bhaṇụāra, Jaisalmer, no. 171/10); in the manuscript of the Șaḍ̄̄aśyakasūtravṛtti (VS 1298 / 1241 CE) (Jinabhadrasūri Grantha Bhaṇḍāra, Jaisalmer, no. 136/1); in the manuscript of the Sūtrakṛtāngasūtravṛtti (VS 1200 / 1143 CE) (Jinabhadrasūri Grantha Bhaṇdāra, Jaisalmer, no. 4); in the manuscript of the Kalpalatāviveka (Kalpapallavaśeșa) (VS 1205 / 1148 CE) (Jinabhadrasūri Grantha Bhaṇḍāa, Jaisalmer, no. 317); in the manuscript of the Praśnottararatnamālikā (VS 1210 / 1153 CE) (Jinabhadrasūri Grantha Bhandiāra, Jaisalmer, no. 154/13); in the manuscript of the Upadeśapadaprakaraṇalaghuțīkā (VS 1212 / 1155 CE) (Jinabhadrasūri Grantha Bhaṇḍāra, Jaisalmer, no. 214/1); in the manuscript of the Savaga Padikkamana Sutta cunni (Sanskrit: Śrāvakapratikramasūtracūrnii) (VS 1317 / 1260 CE) (Museum of Fine Arts, Boston. Denman Waldo Ross Collection, 30.1.1-229) almost on all folios, see also for symbols, the folios $1 \mathrm{v}-2 \mathrm{r}$, $285 \mathrm{v}$ of this manuscript that are presented by Kim 2015, 68 as Fig. 14; in the manuscript of the Sthānāngasūtravṛtti (VS 1300 / 1295 CE) (Jinabhadrasūri Grantha Bhaṇ̣̂̄ra, Jaisalmer, no. 6); in the manuscript of the Praśnavyākaraṇadaśāngasūtravṛtti (VS 1300 / 1295 CE) (Jinabhadrasūri Grantha Bhaṇdāa, Jaisalmer, no. 23/3).

273 In the manuscript of the Aștasāhasrikā Prajñāpāramitā (NAK 4/1626 / NGMPP A 39/12) and in the manuscript of the Haramekhalā (NAK 1/1231 / NGMPP A 45/7) symbols can also be found around string-holes on the folio. However, in both manuscripts symbols have different shapes in comparison to the symbols found in West Indian manuscripts. 
above). The other is the $\mathrm{HV}_{1}$, in which symbols are only on one side of four folios (on $53 \mathrm{v}, 68 \mathrm{r}, 204 \mathrm{v}$ and 310r). These symbols are identical to most of the symbols appearing at the end of the manuscript chapters. There are no symbols around string-holes in the East Indian manuscripts of my corpus, however one may occasionally find symbols and other decorative elements in some manuscripts of this region. ${ }^{274}$

\subsubsection{Structural and decorative symbols}

All symbols appearing at the end of smaller text units, at the end of chapter or subchapter accompanied by sub-colophon or at the end of text with colophon or colophon-like statements etc. and divide visually units of the text, chapter, sub-chapter and text and at the same time (may) appear in decorative shape, can be understood as structural and decorative symbols in manuscripts.

Almost all symbols or features appearing at the end of chapter, sub-chapter or at the end of text in manuscripts belong to this category. The symbols appearing in other parts of the text (such as beginning or end of smaller text units) that play visual structural role can also be understood as structural and decorative components.

In the following section, some symbols are presented that appear at the beginning of smaller text units, at the end of chapter, at the end of text or within a part of the text, are analysed for how they give special indication of the text contents or exhibit specific importance for the text, tradition or ritual aspects.

274 Decorated string-hole spaces and margins with various motifs can be found e.g. in the manuscript of the Aștasāhasrikā Prajñāpāramitā (Nālandā, Bihar, ca. 1041 CE) (Los Angeles County Museum of Art, M72.20a-b), see Weissenborn 2012, 192 as Abbildung 59 the first, last folios and other two folios, Kim 2013, 51 as Figure 2-3 the first and last folios; in another manuscript containing the same text (Nālandā, Bihar, 1058/1140 CE) (Asia Society, New York Mr. and Mrs John D. Rockefeller $3^{\text {rd }}$ Acquisitions Fund, 1987.1) on 1v, 2r, 299v, 300r, Weissenborn 2012, 193 as Abbildung 61, Kim 2013, 44 as Figure 2-1; in another manuscript of the same text (Nālandā, Bihar, ca. 1039-1069 CE) (Wellcome Library, Sansk $\varepsilon$ I.) on 101v and 102r, Kim 2013, 84, Figure 3-4; in another manuscript containing the same text (Nālandā, Bihar, ca. 1114 CE) (Tibet Museum, Lhasa) on a few folios along with beginning and end, Weissenborn 2012, 202 as Abbildung 77; in another manuscript of the same text (Vikramaśila, ca. 1147 CE) (British Library, London, Or. 6902) on 163v and 164r, Kim 2013, 114 as Figure 4-1; in the manuscript of the Pañcarakșā (ca. 1177 CE) (NAK 5/83) on 57r, 58v, Kim 2015, 59 as Fig. I; in the manuscript of the Aștasāhasrikā Prajñāpāramitā (ca. 1191 CE) on 109v, 110r, 216v, 217r, Kim 2015, 67 as Fig. 12; in the manuscript containing the same text (ca. $12^{\text {th }}$ c.) (NAK 5/196), Kim 2013, 4 as Figure 0-2; in the manuscript of the same text (Nālandā, Bihar, ca. $12^{\text {th }}$ c.) (Royal Asiatic Society, London, Hodgson 1) on a few folios presented by Weissenborn 2012 as Abbildung 1. 


\subsubsection{Examples of symbols with a particular meaning}

At times, the shape of certain symbols clearly represents ritual items relevant to a specific religious or performative tradition. At other times, symbols of a similar relevance can be drawn in a more abstract form. In this instance, the symbols should not be understood as mere decorations, but be evaluated for other, possible, cultural significances. Moreover, the symbols may also bear a close relation to the scribal activity, indicating that the scribes may have been especially aware of the kind of text they were copying.

\subsection{A particular floral symbol in the Suśrutanighantu of SS/N}

Manuscript SS/N contains copies of the Suśrutasamhitā, a medical treatise, and of the Suśrutanighanțu, a thesaurus listing the synonyms of various plants' names. The entire manuscript presents a plethora of symbols: a few dots (type no. 1), simple circles (type no. 2), double circles (type no. 6) and small stylised puṣpikās (circles surrounded by almost semi-circular petals with or without four lines, such as type nos. 7 and 8). All these kinds of symbols are found in the section of the manuscript containing the Suśrutasamhitā, whereas the section containing the Suśrutanighant $u^{275}$ presents only simple circles and double circles (placed after the title at the beginning of each section), with the exception of three stylised puspikās.

Among them, two stylised small puṣpikās of no special aesthetic value are found at the beginning of the sections 'sālasāra ...' ('Sāl tree') and 'elā pippaly àdau ...' ('Cardamom [and] pepper etc.'). Furthermore, a more refined stylised puṣpikā placed between double dandas is found on 217r (line no. 2 above the left string-hole) at the beginning of the section on water-lilies (or lotuses). ${ }^{276}$ Here, there is no title heading of the section, only the symbol, which appears to have been in place of the title. For the symbol and the transliteration of the relevant section see below.

275 The text has been 'edited' by Suvedī/Tivārī 2002 with the title Sauśrutanighantụh.

276 On water-lilies, see Hanneder 2002, 295-308. 


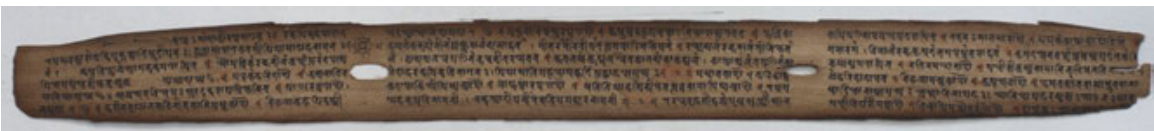

Fig. 3.6.2.1.1-I: Symbol at the beginning of a particular section, fol. $217 \mathrm{r} @ \mathrm{KL}$

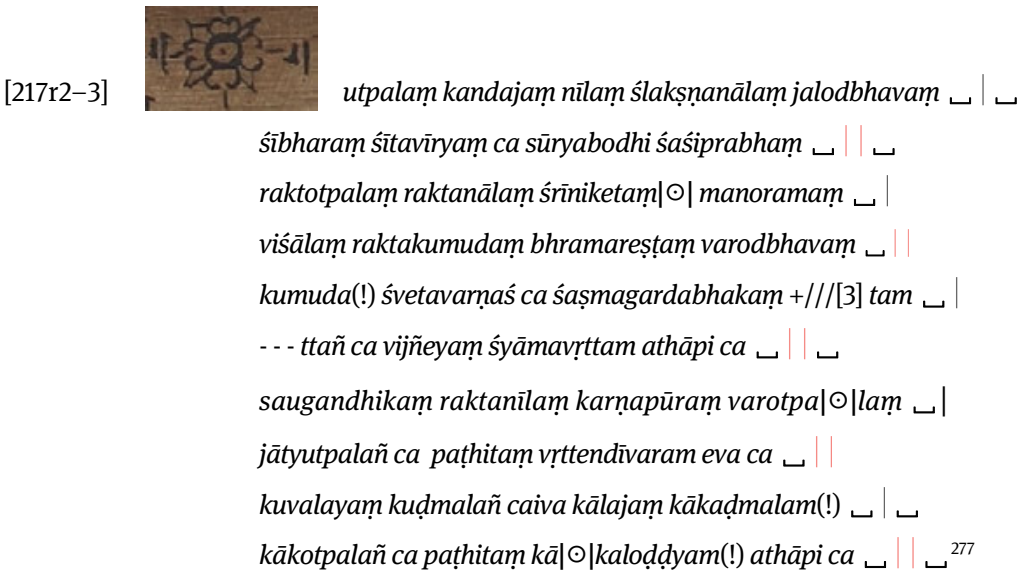

This symbol may have been drawn by the same person or scribe who copied this part of the text. ${ }^{278}$ This is because the double dandas that demarcate the symbol look similar to the double dandas that appear on the same folio (i.e. the double dandas demarcating the double circles in the first line). We can assume the scribe was familiar with (i.e. understood) the content of the text he was copying. As there is no heading for the lotus/water-lily section, we may assume that the scribe drew an abstract representation of a water-lily to provide the reader with a visual clue of that particular section's topic or to give a particular emphasis to that section more generally.

277 I have transcribed the text here as it appears in the manuscript. For the 'edition', see Suvedī/Tivārī 2002, 97, verses 265-269.

278 On suggestions for the identification of the scribe, see Klebanov 2010, 65-66; Klebanov (forthcoming). 


\subsection{Symbols in AT}

The manuscript AT is of a particularly interesting visual organisation. It is an MTM belonging to Vajrayāna Buddhism. Here one 'dot' or circle-like symbol and four stylised puspikās can be found at the end of the texts.

Symbols at the end of mainly one of the texts, ${ }^{279}$ Satsukhāvabodhana, appear to have a special significance. In line no. 3, before the colophon (see transcription and translation below), there is a 'dot-like' symbol placed between a set of double dandas. After the colophon there is a series of three stylised simple pușpikās, each of which is also placed between a set of double dandas. Although they look rather plain, they form a unique set (see Fig. 3.6.2.1.2-II).

The first symbol (i.e. stylised puspikā) is made of a circle surrounded by four petals facing inwards; it can be understood as a representation of a padma ('lotus'), which at a more abstract level represents prajñ $\bar{a}$, i.e. the wisdom-aspect of awakening and the female deity or practitioner. ${ }^{280}$ Keeping this in mind, the second symbol, composed of a circle surrounded by four petals facing outwards, may be interpreted as a vajra ('thunderbolt'); a representation of karunā or upāya ('compassion'), i.e. the compassion-aspect of awakening and the male deity or practitioner. ${ }^{281}$ These interpretations find support in the shape of the third symbol. This can be understood as a samāyoga/samyoga ('combination', 'union') of the first two symbols and, thus, a representation of the union of padma and vajra. ${ }^{282}$ Such a combination is graphically expressed by the petals of the third symbol, which are obtained by drawing together the petals of the first two symbols (for Illustration of symbols, see Fig. 3.6.2.1.2-II below).

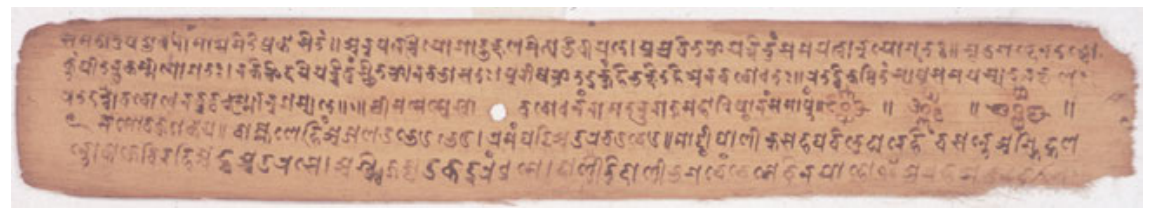

Fig. 3.6.2.1.2-I: Symbols after the chapter colophon, fol. ?v @ General Library, University of Tokyo

279 There is a statement on one of the folios in line no. 3 in this manuscript which reads mentioning a work Dohākoṣa of Sarahapāda as follows kṛtir iyaṃ dohākoṣasarahapādānām.

280 See Snellgrove 1959, Part I, 27 and 137.

281 Ibid. 140.

282 See Pal 1978, Part II, 83: "Many of the later Vajrayāna sects believe that Bodhicitta can be achieved by the combination of right knowledge (prajñā) with right method (upāya), usually regarded as compassion (karunāa). In visual terms the male of the pair represents method or compassion while the female symbolizes knowledge or wisdom.” 
[?v3]

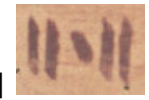

śrīmatsatsukhā $\odot$ vabodhanaṃ nāma tantrarājamahādhișthānam

samāptam

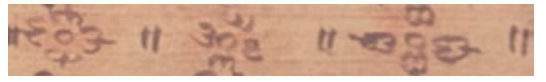

'[Thus], the great Tantra of great power called the glorious awakening true bliss is concluded.'

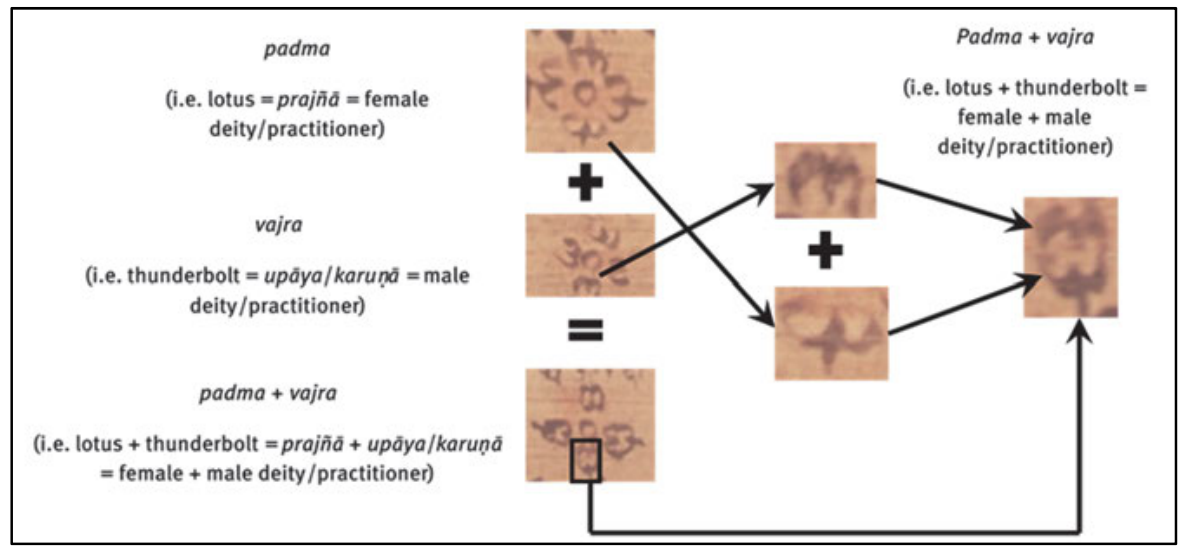

Fig. 3.6.2.1.2-II: Illustration of symbols

From the appearance of these symbols, one can assume that they have probably been drawn by the same scribe who copied the text: the double dandas at the sides of the symbols are similar to the dandas found in the text written on the same folio (for instance double dandas in the first line). We can assume the scribe knew what kind of text he was copying and to which particular school of thought it belonged. Otherwise it would be difficult to justify the occurrence of such a sophisticated set of symbols.

\subsection{Symbols in HT!}

This is a particularly interesting manuscript as its post-colophon (on 59r depicted in Fig. 3.6.2.1.3-I) tells us it was copied in Vikramaśila, one of the greatest 
Buddhist monastic universities of Eastern India. ${ }^{283}$ The scribe records that a Buddhist called Viśuddhirakșita had had the manuscript copied. Such a formulation may be an indication that the manuscript was an official copy for the library of the monastery. ${ }^{284}$ This manuscript contains two circles (on 40r6, 51v3 like type no. 2), three symbols (on 20v1, 40r2, 59r6) that resemble some similarities to type no. 4, two stylised puṣpikās (on 51v3 like type no. 15; on 59r5 like type no. 16) and two florally stylised vajras (on 48r6, 59r4). ${ }^{285}$

One of the two stylised puspikā together with one of the two florally stylised vajras appears at the end of the text accompanying the colophon (on 59r). It is not certain if they have a specific meaning or are merely decorative. As in the example described in 3.6.2.1.2, here too the two symbols may be understood as representing the combination of a vajra (in line no. 4), depicted here in a florally stylised form, and a padma (in line no. 5), drawn in the shape of stylised puṣpikā, i.e. a stylised simple flower. Both symbols have been highlighted.

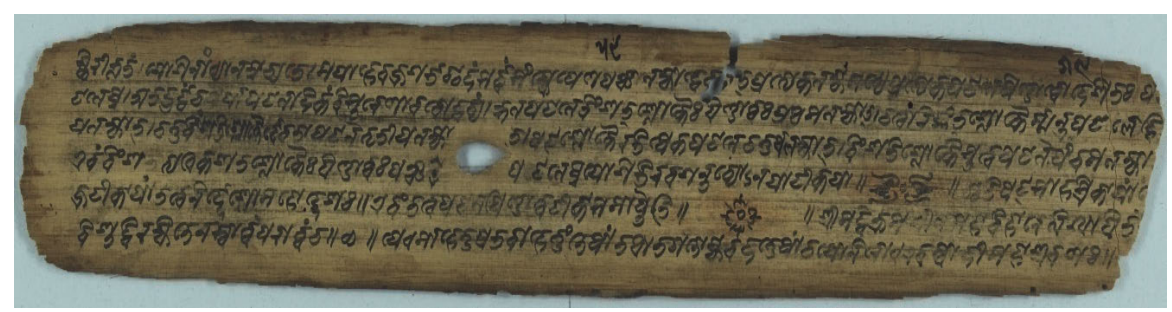

Fig. 3.6.2.1.3-I: Symbols before and after colophon, fol. 59r @ KL

283 See the Manuscript of the Month from 04.2012 at: <http://www.manuscript-cultures.unihamburg.de/mom/2012_04_mom_e.html> (last accessed on 05.11.2018).

284 This and other manuscripts probably copied in Vikramaśila have also been studied by Dr Martin Delhey at the Centre for the Study of Manuscript Cultures (CSMC), Hamburg, in the sub-project C01 titled 'A Twelfth-Century East Indian Monastic Library and its Fate', see Delhey et al. 2015.

285 Examples of nicely drawn realistic vajras can be found (on both string-hole spaces) in the manuscript of the Aștasāhasrikā Prajñāparamitā (NS 135 / 1015 CE) (CUL Add.1643) on 2v, 5v, $8 \mathrm{v}, 11 \mathrm{v}, 113 \mathrm{v}, 14 \mathrm{r}, 20 \mathrm{v}, 40 \mathrm{v}, 44 \mathrm{r}, 86 \mathrm{r}, 89 \mathrm{r}, 99 \mathrm{v}, 120 \mathrm{r}, 123 \mathrm{v}, 127 \mathrm{r}, 133 \mathrm{r}, 139 \mathrm{r}, 147 \mathrm{r}, 151 \mathrm{r}, 157 \mathrm{v}, 164 \mathrm{v}$, 169r, 176v, 179v, 181rv, 182v, 183rv, 184r, 185rv-188rv, 193r, 214v, 216v, 218v, 220v, 221r, 222v, see Losty 1982, 31. Among other symbols, I also present below some florally stylised vajras and 'realistic' vajras that we find in other Buddhist manuscripts. See Kim 2013, 24, Figure I-1 in which a Buddhist priest, with a manuscript in front of him, uses a vajra ritual implement to invoke the Goddess Prajñāpāramitā during the Prajñāpāramitā pūjā. Among other things, florally stylised vajras in some manuscripts contain the text of the Prajñāpa aramitā or Aștasāhasrikā Prajñāparamitā (see section 3.6.2.1.6). 
[59r4-6]

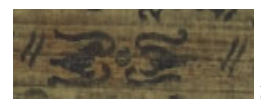

iti șațāhasrikāyāṃ ///++[5]jrațīkāyām tatvanirddeśo

mahoddeśah || evaṃ tatvapaṭalapiṇ̣̂ārthațīkā samāpteti

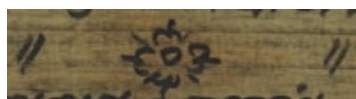

śrīmadvikramaśīlamahāvihāre likhāpitaṃ[6] viśuddhirakṣitena svārthaṃ parārtham ca

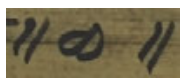

'Thus, [this is] the Mahoddeśa [called] the instruction of truth in the Șațsāhasrikā, in the commentary on the [Heva]jra. Thus, the commentary [called] Tatvapatalapindārtha is concluded. Viśuddhirakșita had had [this] copied in the glorious great Vikramaśíla monastery for himself and others.'

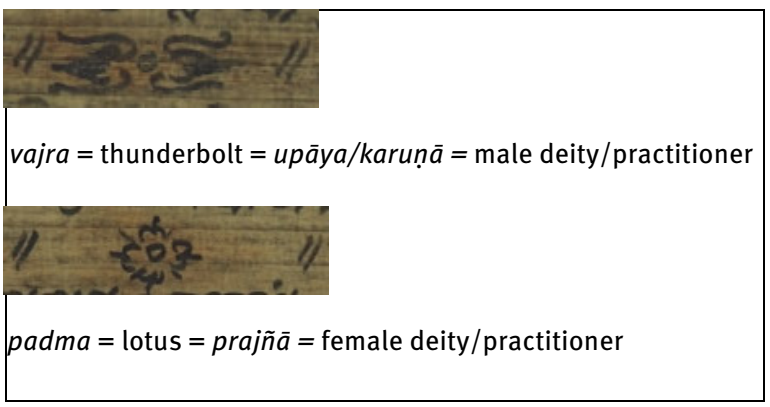

Fig. 3.6.2.1.3-II: Symbols with a particular meaning

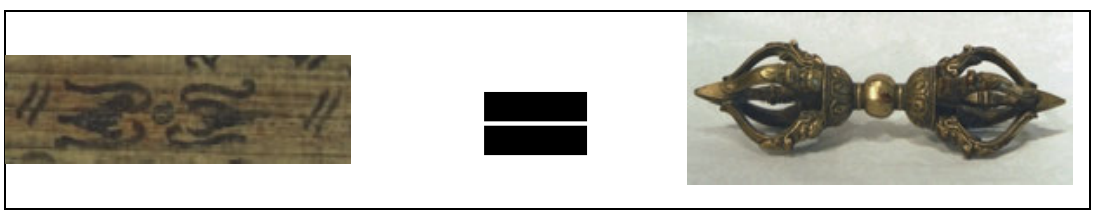

Fig. 3.6.2.1.3-III: Comparison between a florally stylised vajra and a modern one

It seems that both symbols were probably drawn by the person who copied the text. This is evidenced by the double dandas that delimit the symbols being similar to the dandas appearing in other parts of the text (e.g. see double dandas in the fifth line on the same folio). The scribe was probably familiar with the text he was copying and the tradition to which the text belonged. The assumption is supported by the scribe's name given as Viśuddhirakșita, possibly a Buddhist name. 


\subsection{Symbols in AșP1}

This manuscript belongs to Mahāyāna Buddhism. The manuscript exhibits significant examples of symbols. Among which, ${ }^{286}$ we find florally stylised simple symbols. Eight (e.g. on 54v5_ACC, 149r5_ACC, 160v5_B/ACC, 169r1_ACC, 200v2_B/ACC) share an almost similar shape (those in Fig. 3.6.2.1.4-I) (see type no. 30). All these symbols appear at the end of chapters.

It is possible to understand these florally stylised symbols as viśvavajras ('double vajras'), ${ }^{287}$ one of the essential ritual emblems in Buddhism, also associated with Amoghasiddhi ('Unfailing Accomplishment') one of the five Buddhas, ${ }^{288}$ symbolising the principle of absolute stability. These florally stylised double vajras are quite similar in shape to double vajras found in later manuscripts from Nepal or on the piller of stūpas (e.g. Figs. 3.6.2.1.6-XXX and 3.6.2.1.6-XXXI below) etc.

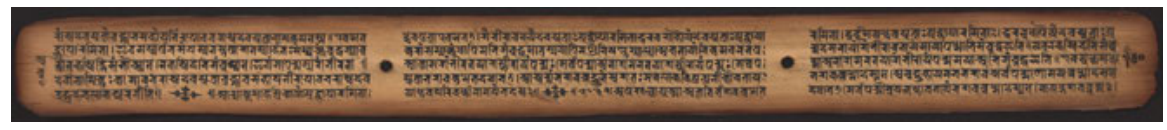

Fig. 3.6.2.1.4-I: Symbols before and after the chapter colophon, fol. 160v @ NAK

286 This manuscript also contains two realistic pusppikās on $26 \mathrm{v} 4$ (see section 3.5.1), two nicely drawn stylised puṣpikās on 2r3_BBOF, 17v4_B/ACC, stylised simple puṣpikās on 54v5_BCC, 149r5_BCC, 206v6_ACC, circles on 92r4, 282v1-2 and four 'figure-eight knot' symbols on 54v5_ACC, 72v5_BCC, 132v5_BCC, 206v6_BCC (probably these symbols can be interpreted as 'endless knot' in this context).

287 While describing the mandala Johnston 2000, Vol. 2, 808 provides an explanation of the viśvavajra symbol as follows: "The viśvavajra is a complex device and a symbol of the absolute, adamantine nature of enlightenment. At the very core of the viśvavajra is a single point that represents the unconditioned potentiality from which all phenomena arise. The structural components of the viśvavajra that appear to radiate out of this infinitesimal core symbolize all aspects of phenomenal existence. Specifically each of the prongs and the centre of the viśvavajra represent one of five jina, or victor, Buddhas. Each of these Buddhas presides over a kula, or family, to which all living creatures in the Buddhist world system belong."

288 The five Buddha families has been given in the Hevajratantra, chapter 5.5-7 in Snellgrove 1959, Part II, 16 as follows: "Vajra Padma tathā Karma Tathāgata Ratnaiva ca | kulāni pañcavidhāny āhur uttamāni mahākṛpa || Vajre Ḍombī bhaven mudrā Padme Nartī tathaiva ca | Karmaṇi Rajaky ākhyata Brāhmaṇi ca Tathāgate || Ratne Caṇ̣̂ālinī jñeyā pañcamudrā viniścitāḥ | tathāgatakulaṃ caitat saṃkṣepenābhidhīyate ||" and its translation can be seen in Snellgrove 1959, Part I, 61 as follows: "Vajra, Padma, Karma, Tathāgata, Ratna; these are known as the Five Families supreme, $\mathrm{O}$ thou of great compassion. These then are their five Mudrā: Dombī for Vajra, Nartī for Padma, Rajaki for Karma, Brāhmaṇi for Tathāgata, and Caṇ̣ālinī for Ratna. For shortness they are called the families of the tathägatas." 


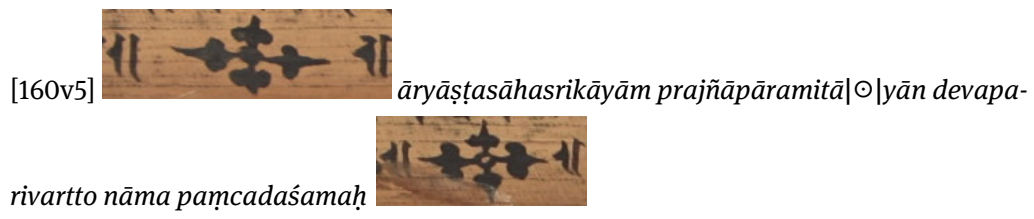

'[Thus], the fifteenth chapter, namely the deva [ends] in the noble Perfection of Wisdom in Eight Thousand Lines. 289

\subsection{Symbols in SDhPS}

This manuscript also belongs to Mahāyāna Buddhism and contains an influential Sūtra text. In terms of symbols, this manuscript is of a particular interest. Among others, ${ }^{290}$ at least seventeen stylised puspikās are to be found at the end of the chapters. Fourteen of them ${ }^{291}$ share an almost identical shape (such as symbols depicted on 20r in Fig. 3.6.2.1.5-I below) and two other symbols (on $31 \mathrm{v} 4$ and 69r1) have a similar shape. Like the symbols described in $\mathrm{Aṣ}_{1}$ above, the symbol in this manuscript can also be understood as viśvavajras.

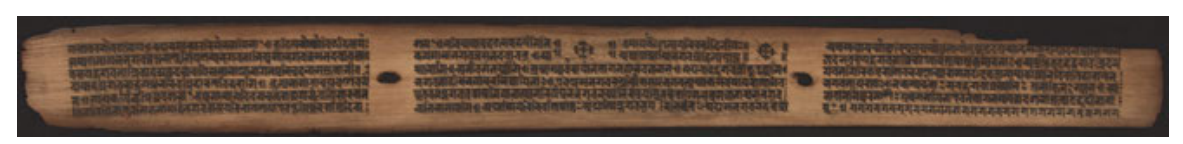

Fig. 3.6.2.1.5-I: Symbols at the end of the chapter, fol. 20r (C) NAK

[20r1]

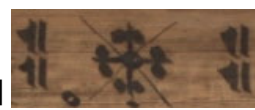

upāyakauśalyaparivartto dvitīyah

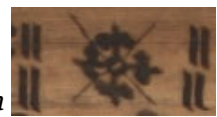

'[Thus], the second chapter, [namely] the upāyakauśalya ('skill in means') [is concluded]'.

289 For the translation of the title of the work I refer here to Conze 1973.

290 Such as 'figure-eight knot-like' symbols on 43v5_ACC (probably this symbol can be interpreted as 'endless knot' in this context), circles 100v6_ACC, 106v_ACC, 116r1_BCC, 'tha' symbols on 46v6_ACC, 58v2_BCC, 62v4_B/ACC, 79r3_ACC, 84v3_ACC, 89v6_BCC, 93v2_ACC, 100v5_BCC, 110r5_ACC, 113v5_ACC, 134v4_B/ACC and a series of three large symbols on 138v, 139rv (see section 3.6.2.2.2 below) can be found in the manuscript.

291 For instance, the symbols on 11r1_BCC, 20r1_B/ACC, 31v4_ACC, 36v6_B/ACC, 43v4_BCC, 65r2_ACC, 69r1_ACC, 77r3_ACC, 79r3_ACC, 89v6_ACC, 106v5_BCC, 113v5_BCC. 
This manuscript will be discussed further below in sections 3.6.2.4.1 and 3.6.2.4.2. In fact, it contains a set of three more large symbols on $138 \mathrm{v}$ (the penultimate folio of the manuscript), and on 139rv (the last folio of the manuscript). The symbol in the middle part on $139 \mathrm{v}$ has a stylised puspikā at its centre that shares the same shape of the other stylised puspikās (as on 20r1 in this manuscript and symbols such as appear on $160 v 5$ in $\mathrm{Ass}_{1}$ ) found in this manuscript. The examples of symbols presented in the following chapter may support my interpretation of this type of florally stylised symbols (in this manuscript and in $\mathrm{Ass}_{1}$ ) as viśvavajras (see section 3.6.2.1.6 below) and other symbols.

\subsection{Symbols in some selected Buddhist manuscripts}

In the following, I present some selected florally stylised or near realistic symbols we find in the Buddhist manuscripts datable as ca. $12^{\text {th }}$ to $19^{\text {th }} \mathrm{c}$. In so doing, we will see the practice and development of usage of symbols in manuscripts (written on palm-leaf and paper) as well as in other places such as on the pillars of a religious site. The examples will also support the interpretation or identification of some of the aforementioned florally stylised symbols, such as vajra (in $\mathrm{HTT}$ ), viśvavajras (in Aș $\mathrm{P}_{1}, \mathrm{SDhPS}$ ) presented above.

\section{MTM of the Bodhicaryāvatāra, Āryavalokiteśvarastotra etc. (KL 127 / NGMPP C}

\section{4/5)}

In the MTM (NS 337 / 1217 CE) (KL 127 / NGMPP C 14/5) containing a few Buddhist texts (e.g. part of the Bodhicaryāvatāra, Āryavalokiteśvarastotra etc.) we find two vajras. ${ }^{292}$ The manuscript is damaged and some folios are in a fragmentary condition. The foliation has not been preserved. One of the vajras can be found in the part of the text of the Äryavalokiteśvarastotra before the colophon in line no. 5 and the other one appears in the part of text of the Bodhicaryāvatāra after the donor phrase (deyadharmo [']yam ... 'this [is] a pious gift ...') in line no. 7 (see Fig. 3.6.2.1.6-I). After the second vajra we find the date written in letter-numerals. ${ }^{293}$

292 One should note that there are at least two different hands clearly visible in this manuscript.

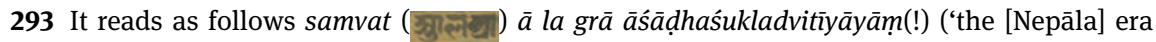
337 , on the $2^{\text {nd }}$ lunar day of bright fortnight of [the month] $\left.\bar{a} s \underline{a} d \underline{d} h a^{\prime}\right)$. The lower part of most of the akșaras of 'śukladvitìy àyām is lost due to the damaged condition of the folio. 
The year should be the NS 337 corresponding to 1217 CE. ${ }^{294}$ From the appearance, the first vajra looks to some extent realistic one and the second one more like florally stylised one. Both are drawn vertically and their height corresponds to one line of the folio. A stylised puspikā can be found after the author line (krtir ācāryaśāntidevasya ... 'the work of preceptor Sāntideva ...') in line no. 5 and before the verse 'ye dharmā ...' In this case, the stylised puṣpikā can probably be interpreted as a representation of a padma ('lotus') pairing the vajra.

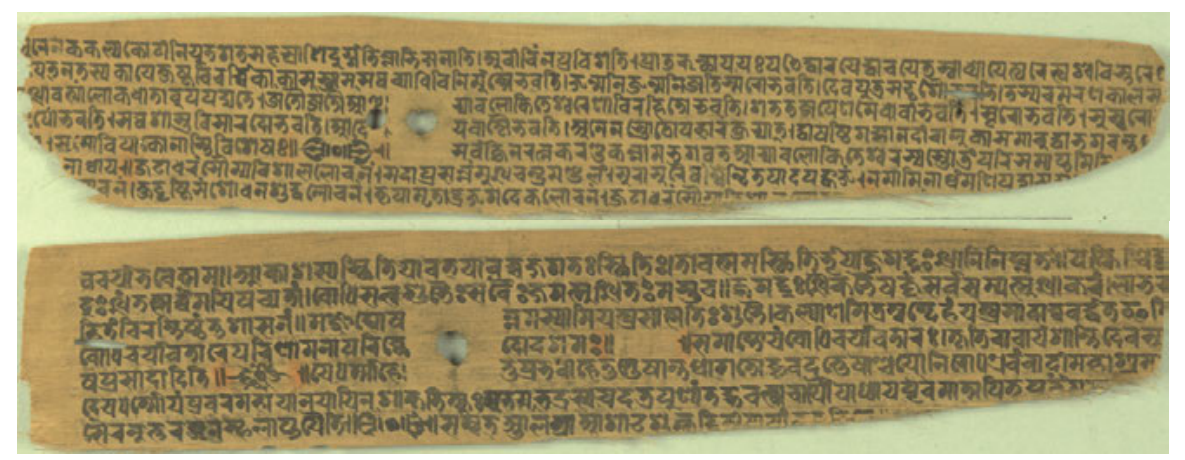

Fig. 3.6.2.1.6-I: Realistic and stylised vajras after the chapter colophon and colophon, fol.? (C) KL

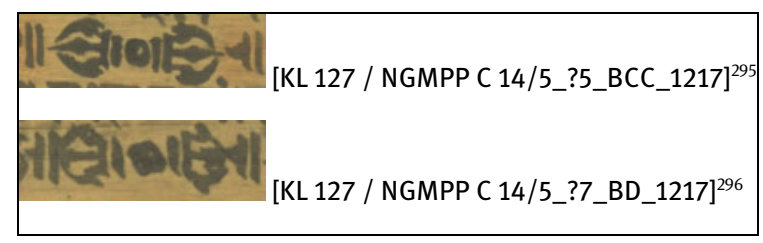

Fig. 3.6.2.1.6-II: Realistic and stylised vajras after the colophon and chapter colophon

294 Working on one of the texts of this MTM, Szántó 2017 recently suggested the date for the part of the MTM as NS 237 corresponding to 1117 CE. It seems he might have also read the same date that we find in the part of the text of the Bodhicaryāvatāra and confused with the first letter-numeral of the year ( 3 ). He probably read it by mistakenly as the letter-numeral for '200'. However, this first letter-numeral probably stands here for '300', see for the letter-numeral for '300', Bendall 1883, Letter-numerals, note; see also Bühler 1896, Tafel IX, column XX, row for the letter-numeral '300'. In this case the year should, therefore, probably be the NS 337 corresponding to $1217 \mathrm{CE}$.

295 In the text of the Āryavalokiteśvarastotra.

296 In the text of the Bodhicaryāvatāra. 


\section{Manuscript of the Aștasāhasrikā Prajñāparamitā (KL 18 / NGMPP C 103/2)}

As stated, the manuscript of the Aștasāhasrikā Prajñāparamitā (ca. 12 ${ }^{\text {th }}$ c.) (KL 18 / NGMPP C 103/2) contains significant items of symbols (see sections 3.5.1 above and 3.6.2.4.2 below). Among others, we find before the $14^{\text {th }}$ chapter colophon on $112 \mathrm{r} 6$ a stylised puspika $\bar{a}$ and after the chapter colophon a florally stylised vajra. The vajra looks very similar to the vajras that we have seen in the aforementioned MTM of the Bodhicaryāvatāra, Āryavalokiteśvarastotra etc. (KL 127 / NGMPP C 14/5). Also in this context the stylised puspiki $\bar{a}$ can probably be interpreted as a representation of a padma ('lotus') that pairs the vajra.

Fig. 3.6.2.1.6-III: Stylised pușpikā and stylised vajra before and after chapter colophon, fol. $112 \mathrm{r} \odot \mathrm{KL}$

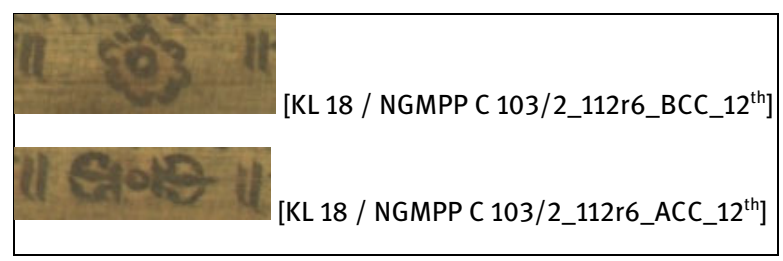

Fig. 3.6.2.1.6-IV: Stylised pușpikā and florally stylised vajra before and after the chapter colophon

Manuscript of the Aștasāhasrikā Prajñāparamitā (NAK 3/359 / NGMPP A 35/11)

The manuscript of the Aștasāhasrikā Prajñāparamita $\bar{a}^{297}$ (ca. $12^{\text {th }}$ c.) (NAK 3/359 / NGMPP A 35/11) displays further remarkable instances with regard to symbols. Before a chapter colophon on line no. 1 there is a stylised puspika on the floral

297 The manuscript contains 68 folios and is in incomplete state. Many folios seem to be missing or perhaps they are misplaced in bundles of other manuscripts. Among available folios, some are broken on the margins (such as the folio in Fig. 3.6.2.1.6-V) and one folio is already in fragmentary condition. There is no date on the available folios. The proposed approximate date for this manuscript is based on the palaeographical ground. 
type of pedestal ${ }^{298}$ and after the chapter colophon a florally stylised vajra in line no. 2 drawn vertically, on a lotus-like element. Additionally the vajra contains further elements on the left and right sides. Both symbols are drawn in 'red' ink. Most part of the chapter colophon is lost due to the damaged condition of the leaf, however, one can still read some part of it. ${ }^{299}$ In this case this should clearly be the second chapter colophon (see note below).

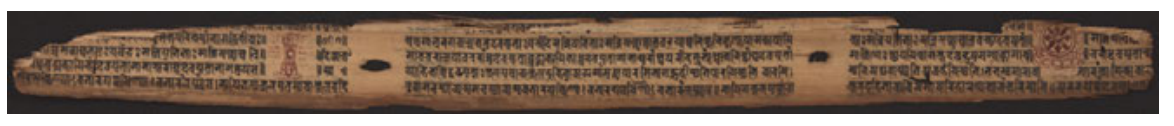

Fig. 3.6.2.1.6-V: Stylised pușpikā and florally stylised vajra before and after the chapter colophon, fol.? (C) NAK

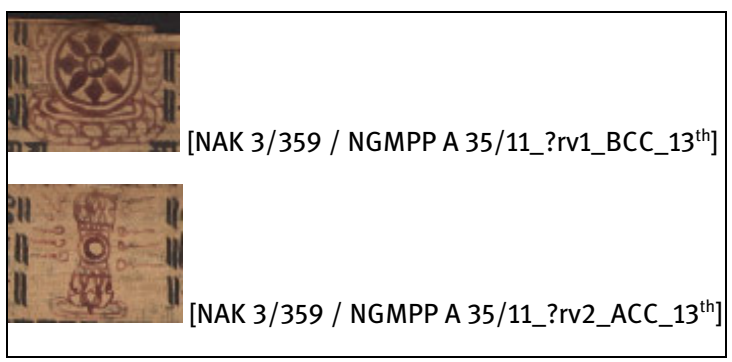

Fig. 3.6.2.1.6-VI: Stylised pușpikā and florally stylised vajra before and after the chapter colophon

\section{Manuscript of the Sādhanamālā (NAK 3/387 / NGMPP B 24/11)}

In the manuscript of the Sädhanamālä $\bar{a}^{300}$ ('Garland of Realisation') (ca. $13^{\text {th }}$ c.) (NAK 3/387 / NGMPP B 24/11) we find a viśvavajra on 146v2 and it appears after the line (āryamārīcīdhārin̄ipāthopadeśa(!) ||). ${ }^{301}$ After the symbol we find invoca-

298 Some scholars have interpreted similar types of symbols as dharmacakra, e.g. Mevissen 1997, 43, Tafel 8. In the example the symbol appears at the very end of the text in one Mongolian block print containing the Pañcarakșā.

299 The remaining part can be read śakraparivartto nāma dvitīyah ('... the second chapter, namely the Śakra ...').

300 See Shastri 1915, 83; Bhattacharyya 1925, xii with siglum N.

301 Its translation as follows 'the teaching lesson on the Dhāriṇi of Āryamārīc $\overrightarrow{\text { ' }}$ 
tions. ${ }^{302}$ The symbol looks like an almost realistic one. Generally the height of the symbol is supposed to be three lines of the folio. However, the folio contains only two lines of the 'main text' in the upper part and a content list which is written in column-like structure in the lower part on the folio. The content list seems to have been written later with the different hand.

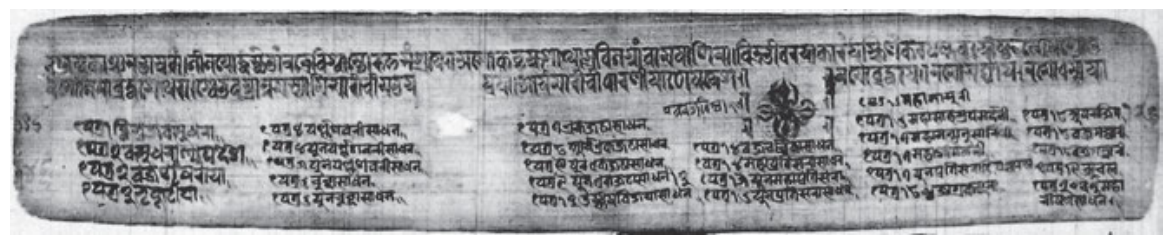

Fig. 3.6.2.1.6-VII: Nearly realistic viśvavajra after the colophon, fol. 146v @ NAK

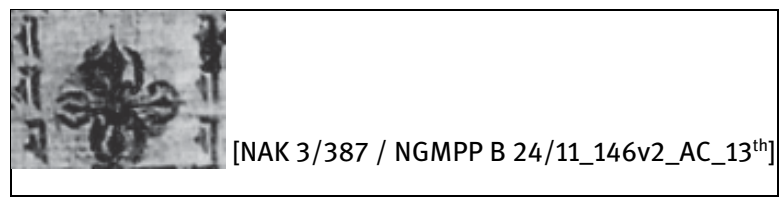

Fig. 3.6.2.1.6-VIII: Nearly realistic viśvavajra after the colophon

\section{MTM of the Bālärkastutițīkā, Daśakrodhāgnisalokasañgraha, Pañcatathāga- tastuti (KL 45 / NGMPP C 4/11)}

In the MTM containing texts of the Bālārkastutițikā, Daśakrodhāgnisalokasañgraha, Pañcatathāgatastuti (NS 545 / 1415 CE) (KL 45 / NGMPP C 4/11) there is also a symbol before the colophon in the part of the Daśakrodhägnisalokasangraha on $37 \mathrm{v} 5$ possibly to be understood as a florally stylised vajra (see Fig. 3.6.2.1.6-XXVIII below). The symbol contains a circle in the centre, two leaflike elements on the left and right sides and the leaves are divided almost in half

302 They read namo buddhāya || namo(!) sanghāya | namo dharmaya(!) || ('homage to Buddha, bow to Sangha, bow to Dharma'). For the translation, minor errors have been read in the most possible correct way. 
by a line. Following which everything is enclosed by an outer line giving the symbol a kind of floral shape. ${ }^{303}$

After the colophon we find a stylised puspikā which may be interpreted here as a padma. As mentioned above, the symbols (i.e. the florally stylised vajra and stylised puspikā) may also be understood as representations of the male and female deities or practitioners corresponding to the upāya and prajñ $\bar{a}$ respectively.

The manuscript contains two dates. The first can be found after the colophon of the Bālārkastutițikā on $37 \mathrm{r} 5^{304}$ and corresponds to $1415 \mathrm{CE}$. The second date is written on the bottom margin on $37 \mathrm{v}^{305}$ and looks rather modern compared to the hand of the aforementioned first date. It was probably added later. The line of date is preceded by a siddham symbol.

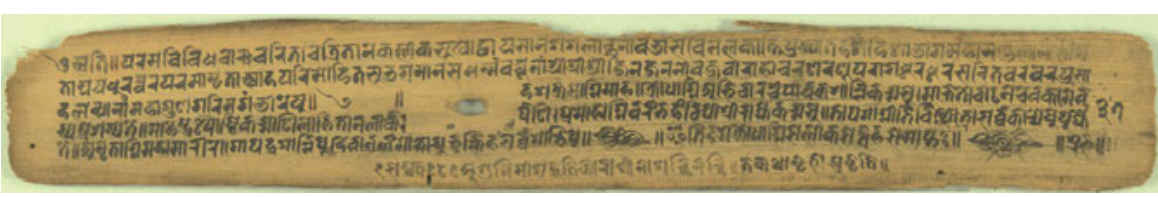

Fig. 3.6.2.1.6-IX: Florally stylised vajra before the colophon, fol. $37 v$ C KL

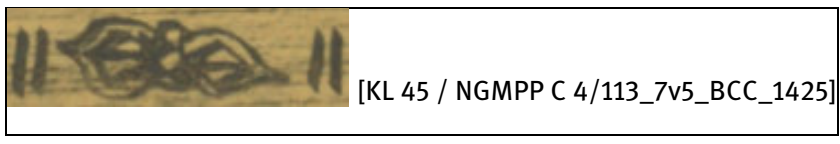

Fig. 3.6.2.1.6-X: Florally stylised vajra before the colophon

303 An almost similar type of florally stylised vajras, however, without outer line also appear in later paper manuscripts e.g. in the manuscript of the Lañkāvatāra (NS 910 / 1790 CE) (NAK 3/610 / B 88/2) on 13v3; in the manuscript of the Samādhirājasūtra (NS 960 / 1840 CE) (NAK 3/611 / NGMPP B 94/1) on 87v3; in the manuscript of the Gaṇavyūha (ca. 19 ${ }^{\text {th }}$ c.) (NAK 3/258 / NGMPP A 110/4) on 101v5, 137v3.

304 It reads nepālikābde 545 pauṣe | śubham || ('in the Nepāla era 545 [and] in the [mongh of] paușa. Auspiciousness')

305 It reads samvat 585 ... ('the [Nepāla] era 585 ...). 


\section{Manuscript of the Pañcarakṣā (NAK 1/1114 / NGMPP A 47/15)}

An example of an almost fully-fledged realistic viśvavajra can be found in the manuscript of the Pañcarakșā ('Five Protections') (NS 596 / 1476 CE) (NAK 1/1114 / NGMPP A 47/15) on the left string-hole space on 99r. In this case the string-hole replaces the centre core of the viśvavajra. On the same folio there are four stylised pusspikās where one finds the colophon ${ }^{306}$ and other colophonic features. In addition, a florally stylised viśvavajra is to be found on the left string-hole space in another manuscript (ca. $15^{\text {th }} / 16^{\text {th }}$ c.) (KL 108 / C 11/4) which contains the same text (see below).

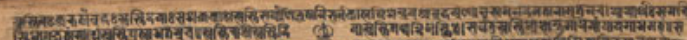

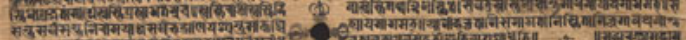

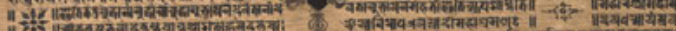

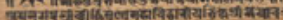

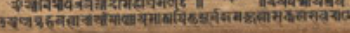

Fig. 3.6.2.1.6-XI: Realistic viśvavajra around the string-hole, fol. 99r @ NAK

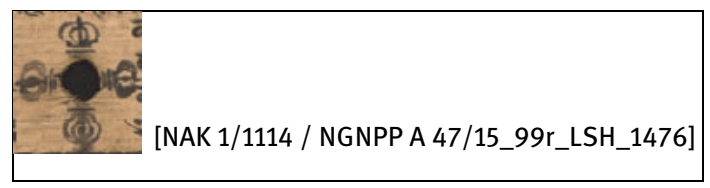

Fig. 3.6.2.1.6-XII: Realistic viśvavajra around the string-hole

\section{Manuscript of the Pañcarakṣā (KL 108 / NGMPP C 11/4)}

We also find, one florally stylised viśvavajra in another manuscript of the Pañcarakșā (ca. 15 $5^{\text {th }} / 16^{\text {th }}$ c.) (KL 108 / NGMPP C 11/4) around the left string-hole space and one stylised puspikā around the right string-hole space on $63 \mathrm{v}$. The stylised puṣpikā can probably be understood in this context as a padma pairing the stylised viśvavajra. As with the aforementioned example, the string-hole replaces the centre core of the viśvavajra and the centre part (i.e. circle) of the stylised pusspikā. Furthermore, we find four petal-like elements in the viśvavajra which may be understood as pointing of the four directions.

306 The colophon on 99r4 reads mahārakșā mahāmantrānuśāriṇi mahāvidyārājñ̃i samāptah(!) || ('[thus], the great protection, the Mahāmantrānuśāriṇi, the queen of great wisdom is concluded'). 


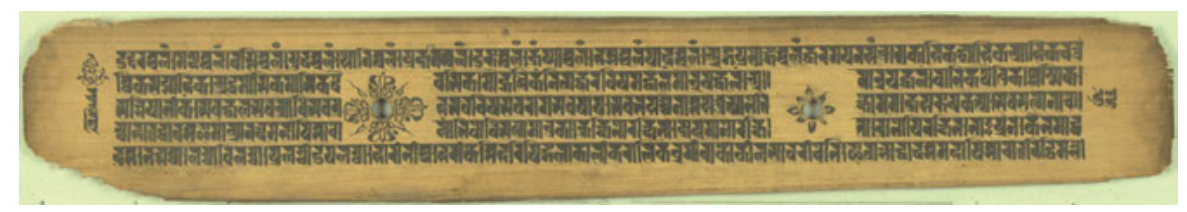

Fig. 3.6.2.1.6-XIII: Florally stylised viśvavajra and stylised puṣpikā around the string-holes, fol. $63 \mathrm{v} @ \mathrm{KL}$

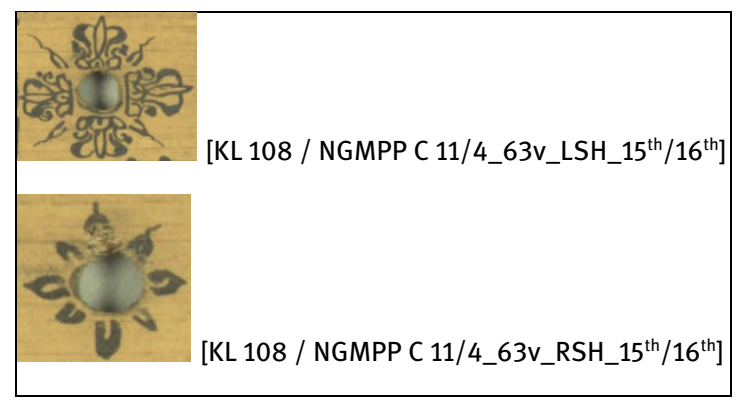

Fig. 3.6.2.1.6-XIV: Florally stylised viśvavajra and stylised puṣpikā around the string-holes

\section{Manuscript of the Pañcarakșā (KL 105 / NGMPP C 11/2)}

In another manuscript (ca. 17 ${ }^{\text {th }}$ c.) ${ }^{307}$ (KL 105 / NGMPP C 11/2) containing the same text as the aforementioned manuscript there is one stylised simple

307 We do not find the date on the existing folios in the manuscript. The penultimate folio (168rv) is in fragmentary condition and most of the lower part of the folio is broken. Furthermore, the majority of the text in the fragmentary folio is also faded. In the colophonic part we find mentioning of the name of country and name of a King. It reads on 167v5-168r1 as follows svastị̣ śrīnepālavișaye rājadhirājapa[168r1]meśvaraśrīkusaratnamalladevasya(!) vijayajye(!) ('heil! The glorious Nepāla kingdom of the venerable king of great kings, supreme lord, Kusaratnamalladeva'). Before and after the line we find blank spaces. Many parts of the akșaras on $168 \mathrm{r} 1$ are faded. Therefore, some part of the text is illegible. A King called Kusaratnamalla can roughly be read but we know little about him and his period of reign. The last folio (rv) is mainly blank excluding a short line on recto. The line seems to have been written later in a different hand. It reads mentioning a name of another King: svati(!) śrīmatvișayarājādhirājapala(!)meśvaraparamabhațtāraka śrī 3 lakṣakșminalasiṃhamalladevasya vijayalāryya(!) ('hail! In the victorious [kingdom] of triple venerable Lakșakșminalasiṃhamalladeva, paramount sovereign, supreme lord, king of great kings of glorious kingdom). In this case the King should probably be Lașminnarasiṃhamalla, although it reads the name as 'Lakșakșminalasiṃhamalla'. Actually 
pușpikā on 167v1 before the colophon which might be understood as a padma in this context and after the colophon a florally stylised viśvavajra on $167 \mathrm{v} 2 .{ }^{308}$ After the viśvavajra is the verse 'ye dharma a...' can be found. The height of the puspika is one line of the folio and the height of the viśvavajra two lines of the folio. Additionally, the viśvavajra contains four lines which may be understood as pointing out the four directions.

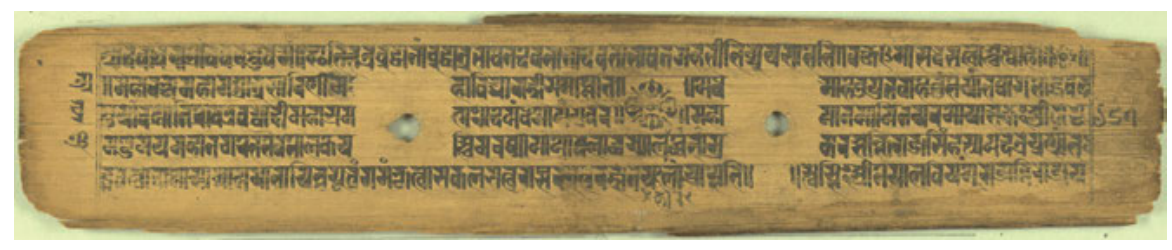

Fig. 3.6.2.1.6-XV: Stylised pușpikā and florally stylised viśvavajra before and after the colophon, fol. $167 \mathrm{v} \odot \mathrm{KL}$

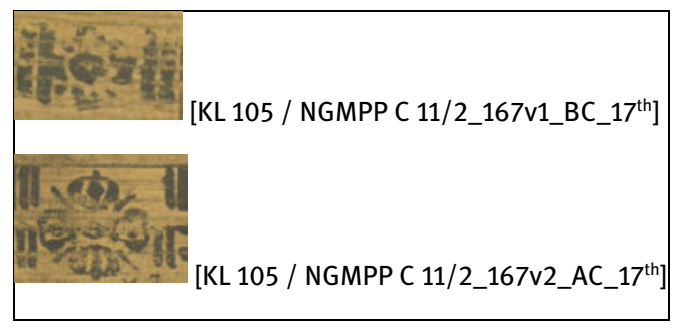

Fig. 3.6.2.1.6-XVI: Stylised pușpikā and florally stylised viśvavajra before and after the colophon

\section{MTM of the Sugatāvadāna, Vasudhārādevīuratakathā (NAK 5/235 / NGMPP B 102/5)}

In the MTM (NAK 5/235 / NGMPP B 102/5) containing two texts i.e. the Sugatāvadāna (on 1r-80r) and the Vasudhärādevīvratakathā (on 81v-96) there is a great variety of symbols before and/or after the chapter colophons and at the

King Lașminarasiṃhamalla reigned in Kathmandu ca. 1620-1641 CE (see Regmi 1966, 55-60). With this we could probably date this manuscript to no later than ca. $17^{\text {th }} \mathrm{c}$.

308 The colophon reads mahārakșā mahāmantrānusārini ma!@mahāvidyārājiñ̄i(!) samāptati(!) ('thus, the great protection, the Mahāmantrānusārini, the queen of great wisdom is completed'). 
end of particular sections etc. The manuscript is written in nillapatra ('black paper') and can probably be dated ca. $18^{\text {th }} \mathrm{c}^{309}$

There are circles (type no. 2), ${ }^{310}$ siddham symbols ${ }^{311}$ and various stylised puspikās $\mathrm{s}^{312}$ some of which can probably be understood as padma according to the context (e.g. see Fig. 3.6.2.1.6-XVII for selected stylised puṣpikās on 39r1, 69v1, $75 \mathrm{v} 4$ below).

There are also six florally stylised vajras on $6 \mathrm{v} 4,38 \mathrm{r} 5,58 \mathrm{v} 4,66 \mathrm{r} 3,69 \mathrm{v} 2$ and 77v5 (see Fig. 3.6.2.1.6-XVII). As seen below all vajras are drawn differently to some degree. Several contain additional elements such as lines or petals and others are drawn simply. The height of all vajras is one line of the folio. We also find florally stylised viśvavajras on 26v2, 39r1 and 78r1. The first two viśvavajras (on 26v2, 39r1) appear before the chapter colophons and their height is two lines of the folio. The latter viśvavajra (on 78r1) appears after the chapter colophon and its height is one line of the folio.

Additionally, two florally stylised śrivvatsas ('endless knot') are on 70r2 and $75 \mathrm{v} 4$. The second śrivatsa contains dots in the inner part. The height of the first śrivatsa is one line of the folio whereas the height of the second is two lines (see also śrivatsa and other symbols in the manuscript of the Sugatāvadānādisañgraha (NS 1006 / 1886 CE) (NAK 4/1381 / NGMPP A 126/4) below). There is also a florally stylised śankha ('conch-shell') on 66r1.

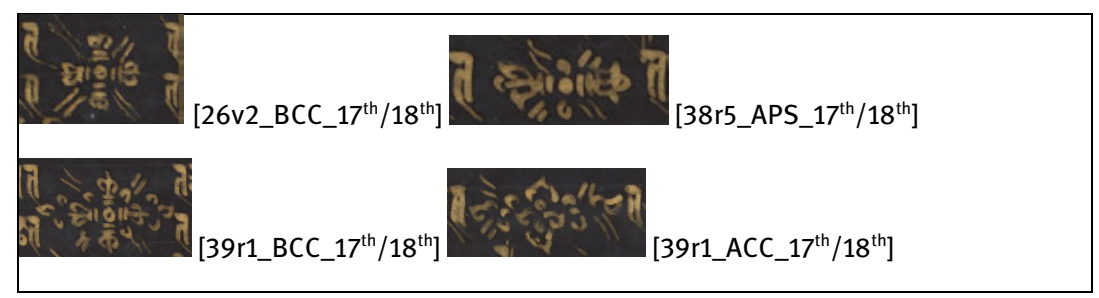

309 The date is suggested on the basis of the similarities of the overall layout, symbols and palaeographical evidence that can be seen in the dated (nilapatra) manuscript containing the Aparimitāyurdhāraṇīsūtra and Sarvadurgatipariśodhana (NS 820 / 1700 CE) (CUL Add.1623). 310 On 4r1, 7r1, 14r1, 16r2, 16r5, 20v5, 21v3, 26v3, 28r1, 35v5, 37r5, 46v1, 47r3, 50v2, 60v5, 61v4, 63r4, 65r4, 70v4, 71v3, 72v1, 72v3, 72v5, 73r1, 73r5, 73v1, 73v2, 73v5, 74r1, 74r2, 74r4, 74v1, 74v3, 74v5, 75r3, 78v5, 79r1, 80r5, 80v1.

311 On 28r3, 36v5, 65r4, 71r1, 78r5, 78v3, 79r3, 79v1, $80 \mathrm{r} 4$.

312 See 4v1, 6v5, 11v4, 16r4, 22v2-3, 24r2, 28r3, 29r5, 30v1, 34r1, 35r1, 35r3, 36v3, 39r1, 39v4, 45r1, 45r4-5, 48r1, 57v2, 58v2, 58v5, 62v1, 64v3, 65r5, 65v2-3, 66r1, 68v2, 69r4, 69v1, 71r1, 71r3, 75r4, 75v3, 78v1, 79r2, 79v4, 80r1, 80r4, 80v1. 


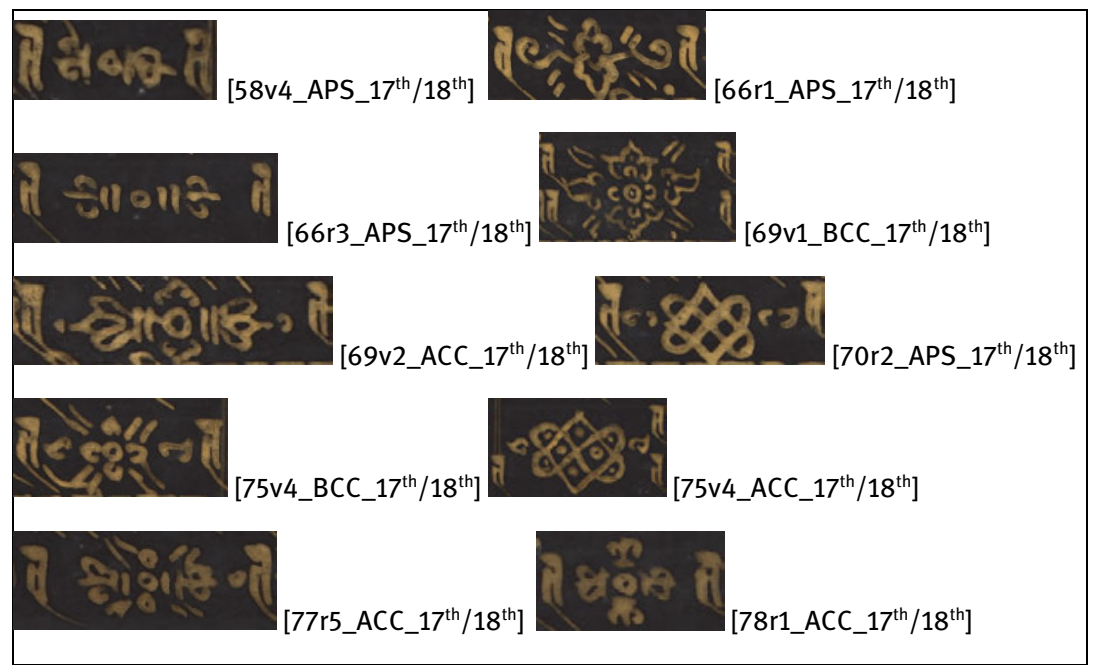

Fig. 3.6.2.1.6-XVII: Various symbols

\section{Manuscript of the Lalitavistara (NAK 4/9 / NGMPP B 99/5)}

In the (paper) manuscript of the Lalitavistara ('the Play in Full') (NS 829 / 1709 CE) (NAK 4/9 / NGMPP B 99/5) there are various kinds of symbols, such as circles, a variety of stylised puṣpikās (such as on 192v6), a realistic simple puṣpikā with a stalk, a florally stylised vajra and a realistic viśvavajra. The realistic pușpikā appears before the $21^{\text {st }}$ chapter colophon on $232 \mathrm{v},{ }^{313}$ and in this context may be interpreted as a padma. After the same chapter colophon on the same line no. 6 we find a florally stylised vajra. The vajra comprises two leaf-like elements on the left and right with a vertical line at their centre, one circle and two sets of three dots in the centre. An almost realistic viśvavajra is drawn after the colophon on 299 r $3 .{ }^{314}$

313 The chapter colophon reads on 232v6 māragharșaṇaparivartto nāmaikavimsśatimaḥ ([thus], the $21^{\text {st }}$ chapter, namely the māragharșaṇa [is concluded]).

314 The colophon reads on 299r2-3 samāptam cedam sarvabodhisatvacaryāprasthānam iti \|| lalitavistaro(!) nāma mahāyānasūtram parisamāptam ('thus, the path of deeds of all Bodhisattvas is also entirely completed. The Mahāyānasütra called the Play in Full is entirely concluded'). 


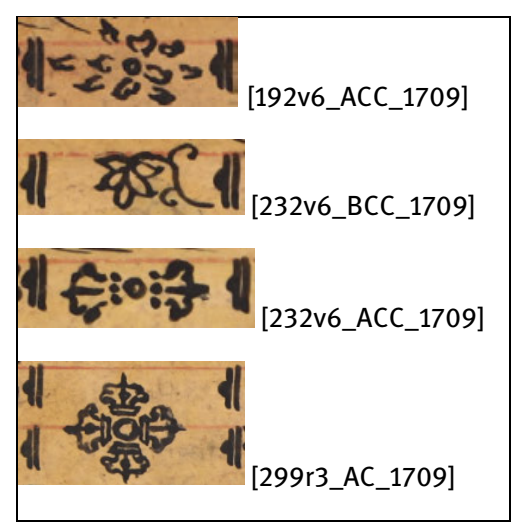

Fig. 3.6.2.1.6-XVIII: Stylised and realistic pușpikās, stylised vajra and realistic viśvavajra

\section{Manuscript of the Lañkāvatāra (NAK 3/610 / NGMPP B 88/2)}

In terms of symbols, the (paper) manuscript of the Lankāvatära ('the Descent into Lañkä) (NS 910 / 1790 CE) (NAK 3/610 / NGMPP B 88/2) exhibits further noteworthy examples. In the manuscript we find, among others, two symbols that may be understood as florally stylised vajras. The first florally stylised vajra appears after the $1^{\text {st }}$ chapter colophon on $13 \mathrm{v} 3$ here drawn vertically with its height corresponding to two lines of the folio. A nearly similar vajra can also be found after the chapter colophon in the manuscript of the Samädhirājasūtra (NS 960 / 1840 CE) on $87 \mathrm{v} 3$ (see below). ${ }^{315}$

The second florally stylised vajra comprises two petal-like elements with a line its centre and appears before the $9^{\text {th }}$ chapter colophon on $162 \mathrm{v} 6$. Near similar symbols can also be found e.g. in the MTM of the Bālärkastutițikā, Daśakrodhāgnisalokasanggraha, Pañcatathāgatastuti on 37v (see Fig. 3.6.2.1.6-IX above); ${ }^{316}$ in the manuscript of the Gandavyūha on 101v5, 137v3 (see below). ${ }^{317}$

Furthermore, some of the stylised puspikikas of this manuscript (such as on 13v2) share close similarities in appearance to symbols featuring in a few other manuscripts. ${ }^{318}$

315 See NAK 3/611 / NGMPP B 94/1.

316 See KL 45 / NGMPP C 4/11.

317 See NAK 3/258 / NGMPP A 110/4.

318 See the manuscript of the Samādhirājasūtra (NS 960 / 1840 CE) (NAK 3/611 / NGMPP B 94/1) on 66v3, 87v3; in the manuscript of the Prajñāpāramitā (NS 961 / 1841 CE) (NAK 4/215 / NGMPP B 90/2) on 55r1; in the manuscript of the Saddharmapuṇarinkasūtra (NS 962 / 1842 CE) (NAK 4/217 / NGMPP 


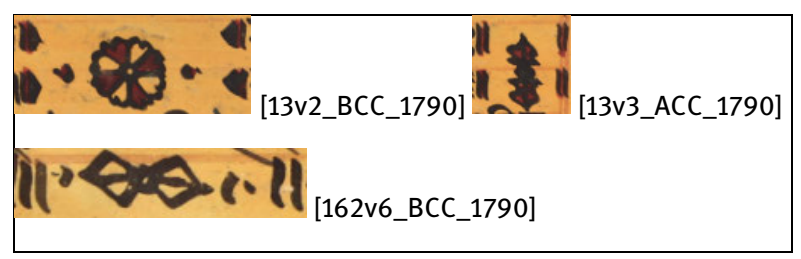

Fig. 3.6.2.1.6-XX: Stylised pușpikā and florally stylised vajras

\section{Manuscript of the Samādhiräjasūtra (NAK 3/611 / NGMPP B 94/1)}

Additionally, the (paper) manuscript of the Samādhiräjasūtra ('the King of Samādhi') (NS 960 / 1840 CE) (NAK 3/611 / NGMPP B 94/1) displays some striking symbols. Of the various stylised pușpikās before and/or after the chapter colophons (such as on 66v3), we find two florally stylised vajras and a few florally stylised viśvavajras in this manuscript.

The first vajra appears after the $20^{\text {th }}$ chapter colophon on $87 \mathrm{v} 3$ and is drawn vertically at a height of nearly two lines of the folio. The second florally stylised vajra can be found before the $35^{\text {th }}$ chapter colophon on 172v7. However, other additional elements such as 'curved lines' or 'half circles' with dot(s) appear around it. After that a florally stylised viśvavajra containing an additional element appears after the chapter colophon on 173r1, the height of the viśvavajra is two lines of the folio.

There are florally stylised symbols on $66 \mathrm{v} 4$ that may be interpreted as florally stylised viśvavajra. The symbol contains a circle at the centre, four leaf-like elements on four sides divided nearly in half by a line. After that it is enclosed by an outer line giving the whole symbol a kind of floral form. In this context one may speculative the use of the extra line is as a protective element for the viśvavajra. On the left and right sides of the viśvavajra we find elements with a 'half-circle' or a 'curved line' facing outside containing a 'dot' or 'line'. Almost similar symbols can also be found in other manuscripts. ${ }^{319}$ Furthermore, some of the stylised pușpikās of this manuscript (such as on 66v3) display close similarities in appearance to symbols found in other manuscripts. ${ }^{320}$

A 128/20) on 126r2; in the manuscript of the Gandavyūha (NS 966 / 1846 CE) (NAK 3/284 / NGMPP A 110/1) on 223v3; in the manuscript of the Gandavyūha (NS 972 / 1852 CE) (NAK 5/75 / NGMPP A 110/3) on 130v2; in the manuscript of the Gandavyūha (ca. 19 ${ }^{\text {th }}$ c.) (NAK 3/258 / NGMPP A 110/4) on 53r2.

319 E.g. in the manuscript of the Prajñāpāramitā (1841 CE) (NAK 4/215 / NGMPP B 90/2) on 132r5; in the manuscript of the Saddharmapundarikasūtra (NS 962 / 1842 CE) (NAK 4/217 / NGMPP A 128/20) on 33v3; in the manuscript of the Gandavyūha (1852 CE) (NAK 5/75 / NGMPP A 110/3) on 38r8 (without outer line); in the manuscript of the Gandavyūha (ca. $19^{\text {th }}$ c.) (NAK 3/258 / NGMPP A 110/4) on 56v3, $177 \mathrm{r} 6$ (without outer line).

320 E.g. in the manuscript of the Lañkāvatāra (NS 910 / 1790 CE) (NAK 3/610 / NGMPP B 88/2) on 13v2 (see above); in the manuscript of the Prajñāpāramitā (NS 961 / 1841 CE) (NAK 4/215 / B 


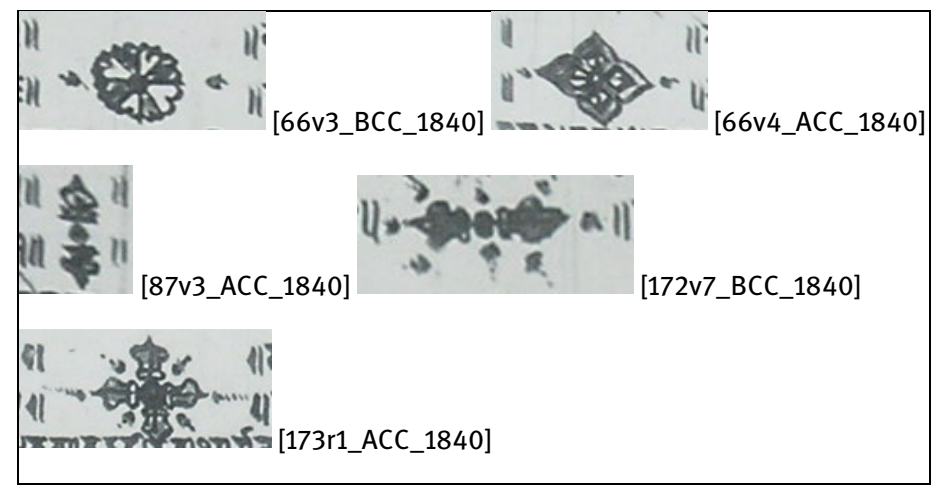

Fig. 3.6.2.1.6-XXI: Stylised pușpikā, florally stylised vajras and viśvavajras

\section{Manuscript of the Prajñāpāramitā (NAK 4/215 / NGMPP B 90/2)}

In the (paper) manuscript of the Prajñāpāramitā (NS 961 / 1841 CE) (NAK 4/215 / NGMPP B 90/2) among various kinds of stylised pușpikās (such as on 55r1) and siddham symbols, there are some florally stylised viśvavajras (e.g. on 132r5). The appearance of the viśvavajras in this manuscript closely resemble florally stylised viśvavajras found in other manuscripts. ${ }^{321}$ The appearance of the stylised pușpikās in this manuscript (e.g. 55r1) display close similarities to symbols found in other manuscripts. ${ }^{322}$

90/2) on 55r1; in the manuscript of the Saddharmapuṇarīkasūtra (NS 962 / 1842 CE) (NAK 4/217 / NGMPP A 128/20) on 126r2; in the manuscript of the Gandavyūha (NS 966 / 1846 CE) (NAK 3/284 / NGMPP A 110/1) on 223v3; in the manuscript of the Gandavyūha (NS 972 / 1852 CE) (NAK 5/75 / NGMPP A 110/3) on 130v2; in the manuscript of the Gandavyūha (ca. $19^{\text {th }}$ c.) (NAK 3/258 / NGMPP A 110/4) on 53r2.

321 See the manuscript of the Samādhirājasūtra (NS 960 / 1840 CE) (NAK 3/611 / NGMPP B 94/1) on 66v4; in the manuscript of the Saddharmapundarīkasūtra (NS 962 / 1842 CE) (NAK 4/217 / NGMPP A 128/20) on 33v3; in the manuscript of the Gandavyūha (1852 CE) (NAK 5/75 / NGMPP A 110/3) on 38r8 (without outer line); in the manuscript of the Gandavyūha (ca. $19^{\text {th }} \mathrm{c}$.) (NAK 3/258 / NGMPP A 110/4) on 56v3, 177r6 (without outer line).

322 For instance, in the manuscript of the Lankkāvatāra (NS 910 / 1790 CE) (NAK 3/610 / NGMPP B 88/2) on 13v2; in the manuscript of the Samādhirājasūtra (NS 960 / 1840 CE) (NAK 3/611 / NGMPP B 94/1) on 66v3, 87v3; in the manuscript of the Saddharmapundarikasūtra (NS 962 / 1842 CE) (NAK 4/217 / NGMPP A 128/20) on 126r2; in the manuscript of the Gandavyūha (NS 966 / 1846 CE) (NAK 3/284 / NGMPP A 110/1) on 223v3; in the manuscript of the Gaṇdavyūha (NS 972 / 1852 CE) (NAK 5/75 / NGMPP A 110/3) on 130v2; in the manuscript of the Gaṇdavyūha (ca. $19^{\text {th }}$ c.) (NAK 3/258 / NGMPP A 110/4) on 53r2. 


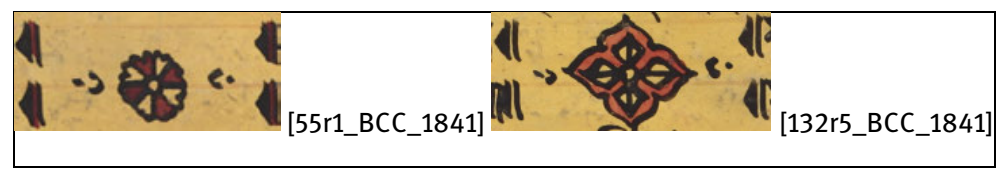

Fig. 3.6.2.1.6-XXII: Stylised pușpikā and florally stylised viśvavajra

\section{Manuscript of the Saddharmapuṇ̣̣arīkasūtra (NAK 4/217 / NGMPP A 128/20)}

The (paper) manuscript of the Saddharmapundarīkasūtra (NS 962 / 1842 CE) (NAK 4/217 / NGMPP A 128/20) also exhibits remarkable examples of symbols. Among various kinds of stylised puspikās the manuscript contains, two siddham symbols, one florally stylised vajra, one florally stylised șațkona ('six-angled') symbol, and many florally stylised viśvavajras such as the one after the chapter colophon on 33v3 (see Fig. 3.6.2.1.6-XXIII).

Many of the stylised pușpikās (see 126r2) in this manuscript are quite similar to stylised puṣpikās in other manuscripts. ${ }^{323}$ The florally stylised vajra before the chapter colophon on 183v4 in this manuscript is another striking example in terms of form. The symbol is drawn vertically containing additional elements such as two 'curved lines' and one semi-circle with a dot on left and right sides. After the same chapter colophon there is a șațkona symbol demarcated by an outer line. Furthermore, the florally stylised viśvavajra in this manuscript are almost identical in form to symbols in other manuscripts. ${ }^{324}$

323 For instance, in the manuscript of the Lankkāvatāra (NS 910 / 1790 CE) (NAK 3/610 / NGMPP B 88/2) on 13v2; in the manuscript of the Samādhirājasūtra (NS 960 / 1840 CE) (NAK 3/611 / NGMPP B 94/1) on 66v3, 87v3; in the manuscript of the Prajñāpāramitā (NS 961 / 1841 CE) (NAK 4/215 / B 90/2) on 55r1; in the manuscript of the Gandavyūha (NS 966 / 1846 CE) (NAK 3/284 / NGMPP A 110/1) on 223v3; in the manuscript of the Gandavyūha (NS 972 / 1852 CE) (NAK 5/75 / NGMPP A 110/3) on 130v2; in the manuscript of the Gandavyūha (ca. 19 $9^{\text {th }}$ c.) (NAK 3/258 / NGMPP A 110/4) on 53r2.

324 For instance, in the manuscript of the Samādhirājasūtra (NS 960 / 1840 CE) (NAK 3/611 / NGMPP B 94/1) on 66v4; in the manuscript of the Prajñāpāramitā (1841 CE) (NAK 4/215 / NGMPP B 90/2) on 132r5; in the manuscript of the Gandavyūha (1852 CE) (NAK 5/75 / NGMPP A $110 / 3$ ) on 38 r8 (without outer line); in the manuscript of the Gandavyūha (ca. $19^{\text {th }}$ c.) (NAK 3/258 / NGMPP A 110/4) on 56v3. 


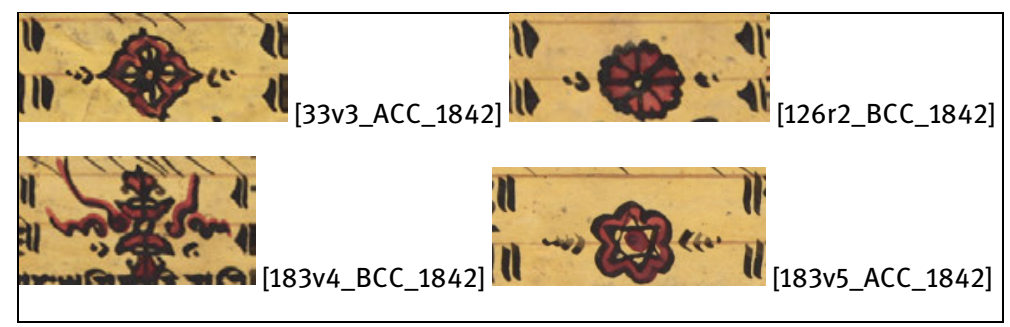

Fig. 3.6.2.1.6-XXIII: Stylised pușpikā, florally stylised vajra and viśvavajra

\section{Manuscript of the Gaṇdavyūha (NAK 3/284 / NGMPP A 110/1)}

The (paper) manuscript of the Gandaryūha ('the Array of Flowers') (NS 966 / 1846 CE) (NAK 3/284 / NGMPP A 110/1) includes, among various kinds of stylised puṣpikās and siddham symbols, a few florally stylised symbols which and their appearance, can most probably be understood as viśvavajra such as on 324r5. Like florally stylised viśvavajras in other manuscripts, ${ }^{325}$ the viśvavajra is here are also comprised of four leaf-like elements in which a line touches the centre core or circle and the line parts the four leafy elements almost in half. In addition, the symbol contains an outer line which encloses its inner parts. Furthermore, some of the stylised puspikās (such as on 223v3) are identical to the stylised puspikik found in other manuscripts. ${ }^{326}$

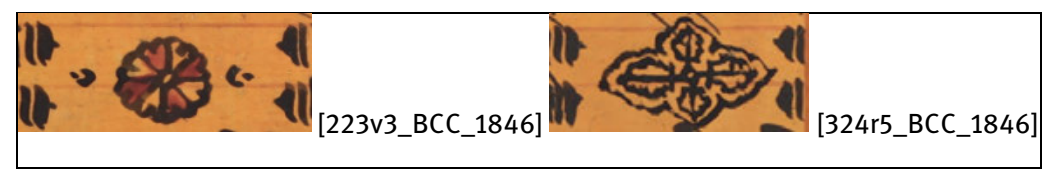

Fig. 3.6.2.1.6-XXIV: Stylised pușpikā and florally stylised viśvavajra

325 See the manuscript of the Samādhiräjasūtra (NS 960 / 1840 CE) (NAK 3/611 / NGMPP B 94/1) on 66v4; the manuscript of the Prajñāpāramitā (NS 961 / 1841 CE) (NAK 4/215 / NGMPP B 90/2) on 132r5; the manuscript of the Saddharmapuṇdarikasūtra (NS 962 / 1842 CE) (NAK 4/217 / NGMPP A 128/20) on 33v3 (see above); the manuscript of the Gandavyūha (1852 CE) (NAK 5/75 / NGMPP A 110/3) on 38r8 (without outer line); in the manuscript of the Gandavyūha (ca. $1^{\text {th }}$ c.) (NAK 3/258 / NGMPP A 110/4) on 56v3.

326 See the manuscript of the Lañkāvatāra (NS 910 / 1790 CE) (NAK 3/610 / NGMPP B 88/2) on 13v2; in the manuscript of the Samādhirājasūtra (NS 960 / 1840 CE) (NAK 3/611 / NGMPP B 94/1) on 66v3, 87v3; Prajñāpāramitā (NS 961 / 1841 CE) (NAK 4/215 / B 90/2) on 55r1; in the manuscript of the Saddharmapuṇdarikasūtra (NS 962 / 1842 CE) (NAK 4/217 / NGMPP A 128/20) on 126r2 (see above); in the manuscript of the Gandaryūha (NS 972 / 1852 CE) (NAK 5/75 / NGMPP A 110/3) on 130v2; in the manuscript of the Gandavyūha (ca. 19 ${ }^{\text {th }}$ c.) (NAK3/258 / NGMPP A 110/4) on 53r2. 


\section{Manuscript of the Gaṇdavyūha (NAK 5/75 / NGMPP A 110/3)}

Another (paper) manuscript of the Gandavyūha (NS 972 / 1852 CE) (NAK 5/75 / NGMPP A 110/3) shows interesting examples of symbols. Among them are siddham symbols, various kinds of stylised puṣpikās, a few florally stylised vajras one florally stylised viśvavajra and a florally stylised chattra ('parasol'). Of these, one of the stylised puṣpikās (see 130v2) is similar in appearance to symbols in other manuscripts. ${ }^{327}$

The florally stylised vajras on 160v4, 167v4, 289v4 appear identical. The stylised vajra on $288 \mathrm{v} 4$ also displays many similarities to the aforementioned vajras but here it is drawn vertically and contains an additional element hanging down on the left and right sides. This additional element may be understood as an offering like a 'piece of cloth' or 'scarf' or 'shawl' perhaps intended to pay homage to vajra i.e. a male practitioner or deity.

Additionally, there is a florally stylised viśvavajra on $38 \mathrm{r} 8$, the centre part of which looks similar to the florally stylised viśvavajras of a few other manuscripts. ${ }^{328}$ Here, the symbol is not enclosed by an outer line. However, on six sides of the viśvavajra there are elements with a 'semi-circle' or a 'curved line' facing outside containing a dot. There is also a florally stylised symbol on $289 \mathrm{v} 4$ possibly to be understood as chattra.

327 See the manuscript of the Lañkāvatāra (NS 910 / 1790 CE) (NAK 3/610 / NGMPP B 88/2) on 13v2; in the manuscript of the Samādhirājasūtra (NS 960 / 1840 CE) (NAK 3/611 / NGMPP B 94/1) on 66v3, 87v3; in the manuscript of the Prajñāāāramitā (NS 961 / 1841 CE) (NAK 4/215 / B 90/2) on 55r1; in the manuscript of the Saddharmapundarīkasūtra (NS 962 / 1842 CE) (NAK 4/217 / NGMPP A 128/20) on 126r2; in the manuscript of the Gandavyūha (NS 966 / 1846 CE) (NAK 3/284 / NGMPP A 110/1) on 223v3; in the manuscript of the Gandavyūha (ca. 19 ${ }^{\text {th }}$ c.) (NAK 3/258 / NGMPP A 110/4) on 53r2. 328 For instance, in the manuscript of the Samädhiräjasūtra (NS 960 / 1840 CE) (NAK 3/611 / NGMPP B 94/1) (see above); in the manuscript of the Saddharmapundarīkasūtra (NS 962 / 1842 CE) (NAK 4/217 / NGMPP A 128/20) on 33v3; in the manuscript of the Gandavyūha (ca. $19^{\text {th }}$ c.) (NAK 3/258 / NGMPP A 110/4) on 56v3. 


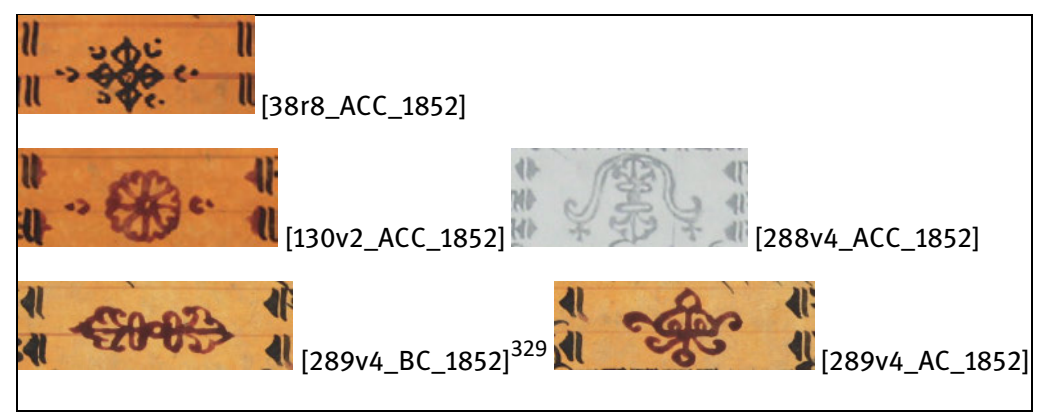

Fig. 3.6.2.1.6-XXV: Stylised pușpikā and florally stylised chattra, vajras and viśvavajra

\section{Manuscript of the Gaṇḍavyūha (NAK 3/258 / NGMPP A 110/4)}

Another (paper) manuscript of the Gandavyūha (19 ${ }^{\text {th }}$ c.) (NAK 3/258 / NGMPP A 110/4) exhibits further striking examples of symbols. These are some floral symbols e.g. on $101 v 5,137 v 3,326 v 2,333 v 2$ that may be interpreted as florally stylised vajras.

The florally stylised vajras on 101v5, 137v3 are composed of two leaf-like elements and one circle in the centre. Both leaf-like elements contain a line dividing them in half. They are drawn horizontally. However, the symbols on 137v3 and on 326v2 are drawn vertically containing lines that touch the top of the symbol and hang down on left and right sides. These lines may be interpreted as an offering object like a 'piece of cloth' or 'scarf' or 'shawl' as has just been seen on the top of the symbol in the manuscript of the Gandavyūha (NS 972 / 1852 CE) on 288v4. ${ }^{330}$ The florally stylised vajras (on 101v5, 333v2) look almost similar to symbols of other manuscripts. ${ }^{331}$ Florally stylised viśvavajras such as on 56v3, 177r6 (without an outer line) seem identical to symbols in other manuscripts. ${ }^{332}$ Other stylised puṣpikās such

329 Similar symbols can be found on 160v4_ACC, 167v4_ACC.

330 See NAK 5/75 / NGMPP A 110/3.

331 See the MTM of the Bālārkastutițīkā, Daśakrodhāgnisalokasañgraha, Pañcatathāgatastuti (NS 545 / 1415 CE) (KL 45 / NGMPP C 4/11) on 37v; in the manuscript of the Lankāvatāra (NS 910 / 1790 CE) (NAK 3/610 / B 88/2) on 13v3; in the manuscript of the Samādhirājasūtra (NS 960 / 1840 CE) (NAK 3/611 / NGMPP B 94/1) on 87v3.

332 E.g. in the manuscript of the Samādhirājasūtra (NS 960 / 1840 CE) (NAK 3/611 / NGMPP B 94/1) on 66v4; in the manuscript of the Prajñāparramitā (1841 CE) (NAK 4/215 / NGMPP B 90/2) on 132r5; in the manuscript of the Saddharmapundarikasūtra (NS 962 / 1842 CE) (NAK 4/217 / NGMPP A 128/20) on 33v3; in the manuscript of the Gandavyūha (1852 CE) (NAK 5/75 / NGMPP A 110/3) on 38r8 (without outer line), 399v1. 
as on 53r2 in this manuscript appear identical to stylised pusppikās seen in the aforementioned manuscripts. ${ }^{333}$

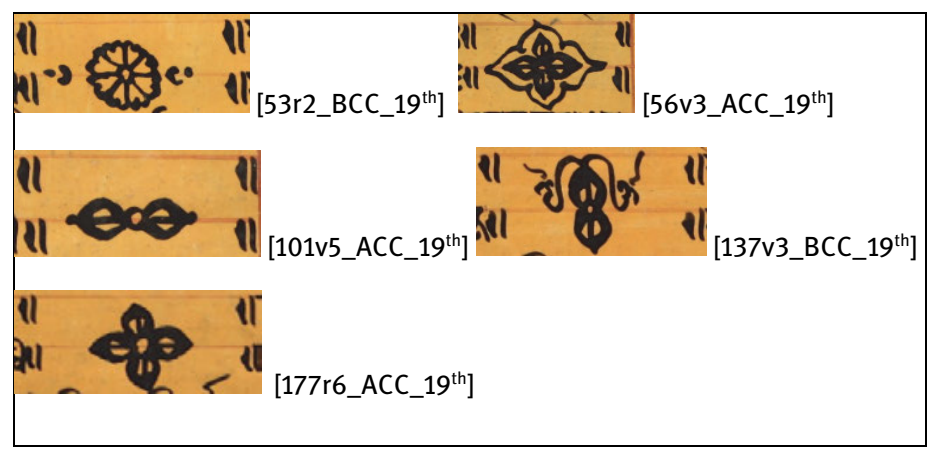

Fig. 3.6.2.1.6-XXVI: Stylised pușpikā, florally stylised vajras and viśvavajras

\section{MTM of the Sugatāvadānādisañgraha (NAK 4/1381 / NGMPP A 126/4)}

The (paper) MTM containing Buddhist texts (NS 1006 / 1886 CE) (NAK 4/1381 / NGMPP A 126/4) exhibits unique examples on the use of symbols. Alongside siddham and stylised pușpikas, a florally stylised śrivatsa ('endless knot') in line no. 2, a śankha ('conch shell') in line no. 2, a stylised puṣpika in line no. 5 which in this context is obviously to be interpreted as padma, a chattra ('parasol') in line no. 5, a vajra in line no. 7, a dhvaja ('banner') in line no. 9, a matsyayugma ('a pair fish') in line no. 9 here depicted in 'white' and 'red' pigment, a kalaśa ('vase', 'water pot') in line no. 12 and a cāmarayugma ('a pair fly-whisks') in line no. 12 almost at the end of the text on $74 \mathrm{v}^{334}$ in the manuscript. ${ }^{335}$

333 See in the manuscript of the Lañkāvatāra (NS 910 / 1790 CE) (NAK 3/610 / NGMPP B 88/2) on 13v2; in the manuscript of the Samādhirājasūtra (NS 960 / 1840 CE) (NAK 3/611 / NGMPP B 94/1) on 66v3, 87v3; in the manuscript of the Prajñāpāramitā (NS 961 / 1841 CE) (NAK 4/215 / B 90/2) on 55r1; in the manuscript of the Saddharmapundarīkasūtra (NS 962 / 1842 CE) (NAK 4/217 / NGMPP A 128/20) on 126r2; in the manuscript of the Gandavyūha (NS 966 / 1846 CE) (NAK 3/284 / NGMPP A 110/1) on 223v3; in the manuscript of the Gaṇdavyūha (NS 972 / 1852 CE) (NAK 5/75 / NGMPP A 110/3) on 130v2.

334 We do not have a running foliation from the beginning to the end in the manuscript (save for the modern example on the bottom left margin of the folio). A new foliation number is found for each new text beginning with ' 1 ' on the upper left and bottom right margins of the manuscript. 


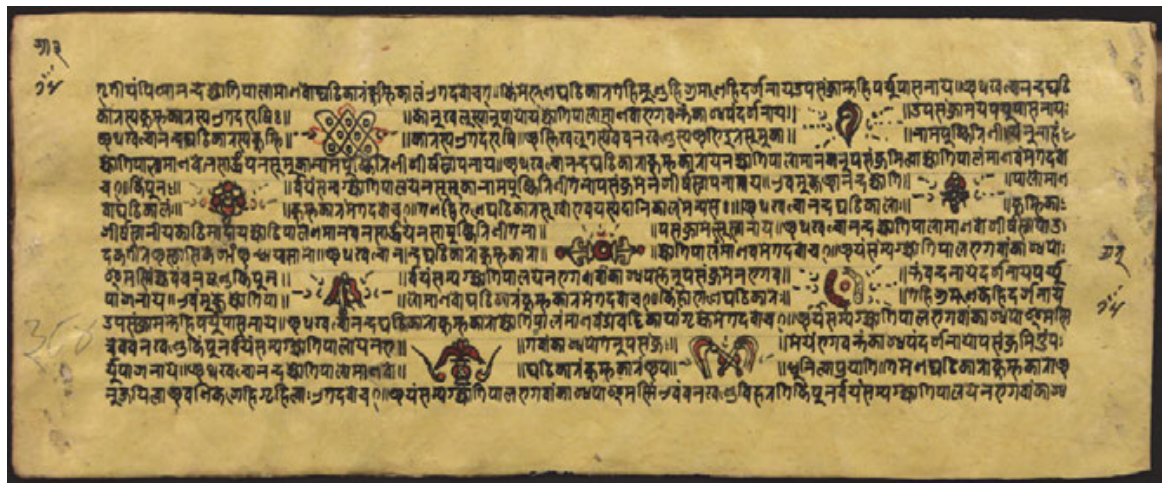

Fig. 3.6.2.1.6-XXVII: Various stylised symbols, fol. 74v @ NAK

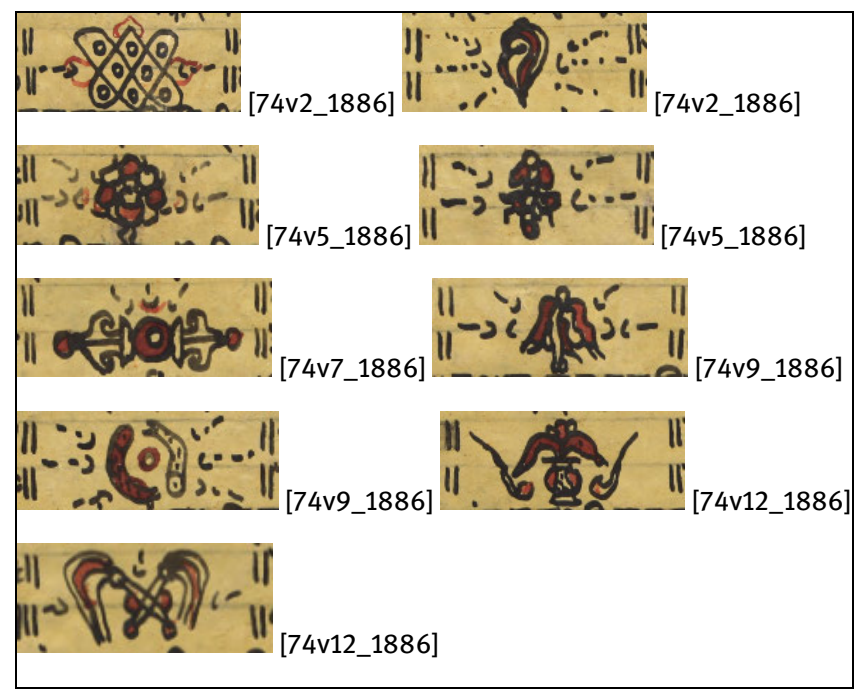

Fig. 3.6.2.1.6-XXVIII: Various florally stylised symbols

335 Here one would normally expect aștamangala symbols ('eight auspicious symbols') such as chattra, matsyayugma, kalaśa, padma, śankha, śrivatsa, dhvaja, dharmacakra that have been of popular use in the Buddhist tradition in various areas of the sub-continent and beyond in diverse places and objects. Here we have a set of nine symbols. The dharmacakra is missing. Câmarayugma and vajra have been added to the group. 
There are two florally stylised vajras on $1 \mathrm{v}$ in line no. 1 at the beginning of one of the texts (i.e. Vajrasattvakāya) in the same manuscript after the invocation ${ }^{336}$ and after the first half of a verse. Both vajras have been drawn vertically containing additional elements on the left and right sides and their height corresponds to two lines of the folio. Furthermore, it is noteworthy that in the near centre of the folio there is a miniature of the Vajrasattva holding a vajra in his right hand. In this context one may deduce the scribe was probably aware of the textual content he was copying which is why he drew the florally stylised vajras that appear after the invocation and the first half of a verse on the folio.

\section{Preliminary conclusions}

Attestations of the use of similar types of florally stylised symbols and other new examples in the MTM containing the texts of the Bālārkastutițīkā, Daśakrodhāgnisalokasañgraha, Pañcatathāgatastuti (KL 45 / NGMPP C 4/11) before the colophon of the Daśakrodhāgnisalokasangraha on 37v5, and near similar florally stylised symbols are in other manuscripts. ${ }^{337}$ There is a near similar symbol on the upper part of the pillar of one of the stūpas $\mathrm{s}^{338}$ at Swayambhunath, Kathmandu (see Figs. 3.6.2.1.6-XXIX and 3.6.2.1.6-XXXI (left)) which is most likely a representation of a vajra. ${ }^{339}$ We may assume here that the florally stylised symbols of the aforementioned manuscripts are florally stylised vajras.

Attestations of florally stylised symbols seen in the aforementioned manuscripts $^{340}$ are also be found e.g. on the upper part of the other side of the pillar of the

336 It reads om namah guruvajrasattvāyaḥ(!) ('om, homage to the preceptor Vajrasattva').

337 See the manuscript of the Lankkāvatāra (NS 910 / 1790 CE) (NAK 3/610 / B 88/2) on 13v3; in the manuscript of the Samādhirājasūtra (NS 960 / 1840 CE) (NAK 3/611 / NGMPP B 94/1) on 87v3; in the manuscript of the Gandaryūha (ca. 19 ${ }^{\text {th }}$ c.) (NAK 3/258 NGMPP A 110/4) on 101v5, $137 v 3$.

338 This stūpa is located in the western part of the premises of Swayambhunath near the entrance to the main stūpa.

339 Dr Costantino Moretti (École française d'Extrême-Orient, Paris) tells of the use of quite similar types of vajras can also be found in some manuscripts from Dunhuang, for instance, in manuscript Pelliot chinois 2105 verso (Bibliothèque nationale de France, Paris), which contains a ritual text, entitled Jin'gangding yuqie niansong guiyi corresponding to sections of two texts ascribed to Amoghavajra. This manuscript may date back to the $10^{\text {th }} \mathrm{c}$. Attestations of such symbols in different manuscript cultures of different areas suggest there is a need for comparative transcultural research on this topic in the future.

340 See the manuscript of the Prajñāpāramitā (NS 961 / 1841 CE) (NAK 4/215 / NGMPP B 90/2) on 132r5; and that of the Saddharmapundarīkasūtra (NS 962 / 1842 CE) (NAK 4/217 / NGMPP A 128/20) on 33v3; the Gandavyūha (NS 972 / 1852 CE) (NAK 5/75 / NGMPP A 110/3) on 38r8 (without outer line); the Gaṇdavyūha (ca. 19 ${ }^{\text {th }}$ c.) (NAK 3/258 NGMPP A 110/4) on 56v3. 
same stūpa at the Swayambhunath, Kathmandu (see Figs. 3.6.2.1.6-XXX and 3.6.2.1.6-XXXI (right)). The florally stylised symbol on the pillar is most likely a representation of a viśvavajra. Here we can deduce that these florally stylised symbols appearing in the aforementioned manuscripts may be interpreted as florally stylised viśvavajras.

These florally stylised viśvavajras of the above (paper) manuscripts, permit the assumption that the florally stylised symbols in the AșP, ${ }^{341}$ and in the SDhPS ${ }^{342}$ are also florally stylised viśvavajras (see Fig. 3.6.2.1.6-XXX below). These and the above examples of vajras suggest a long and significant tradition of the use of such symbols in manuscripts as well at religious sites and other places.

On the position of realistic or florally stylised vajras and viśvavajras, of the preceding examples above, they may appear at the end of the chapter, text and even smaller text units or around the string-holes of the manuscripts.

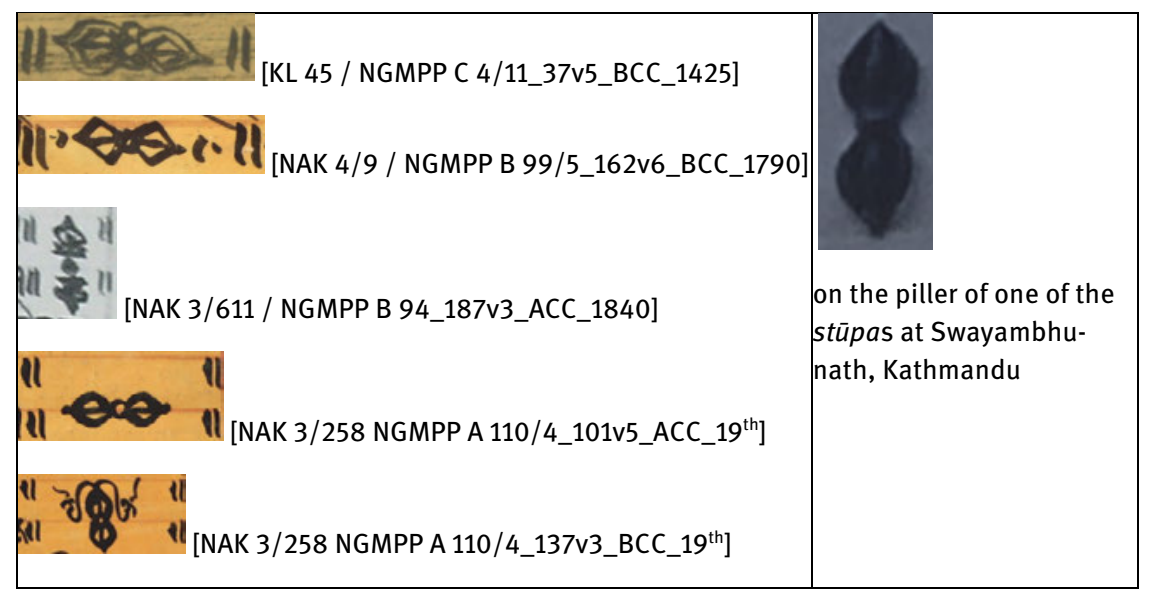

Fig. 3.6.2.1.6-XXIX: Comparison of florally stylised vajras

341 See 54v5_ACC, 149r5_ACC, 160v5_B/ACC, 169r1_ACC, 200v2_B/ACC.

342 See 11r1_BCC, 20r1_B/ACC, 31v4_ACC, 36v6_B/ACC, 43v4_BCC, 65r2_ACC, 69r1_ACC, 77r3_ACC, 79r3_ACC, 89v6_ACC, 106v5_BCC, 113v5_BCC. 


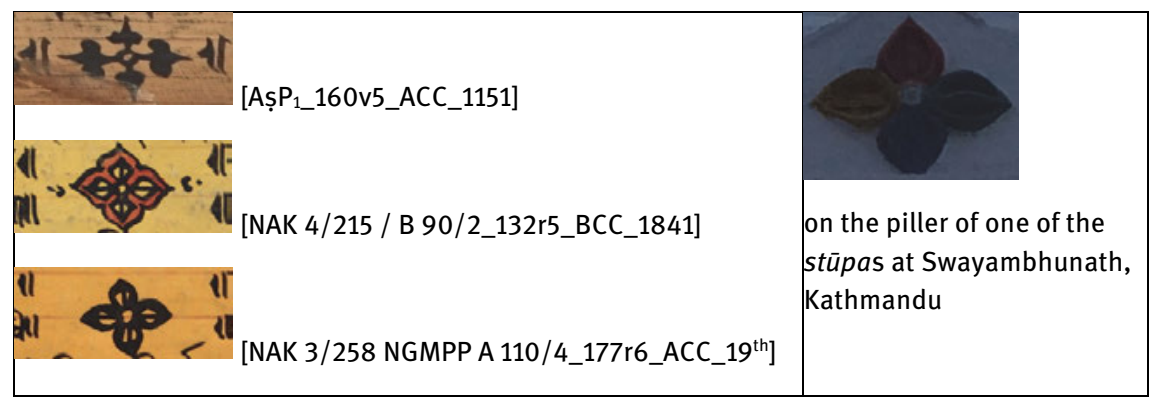

Fig. 3.6.2.1.6-XXX: Comparison of florally stylised viśvavajras
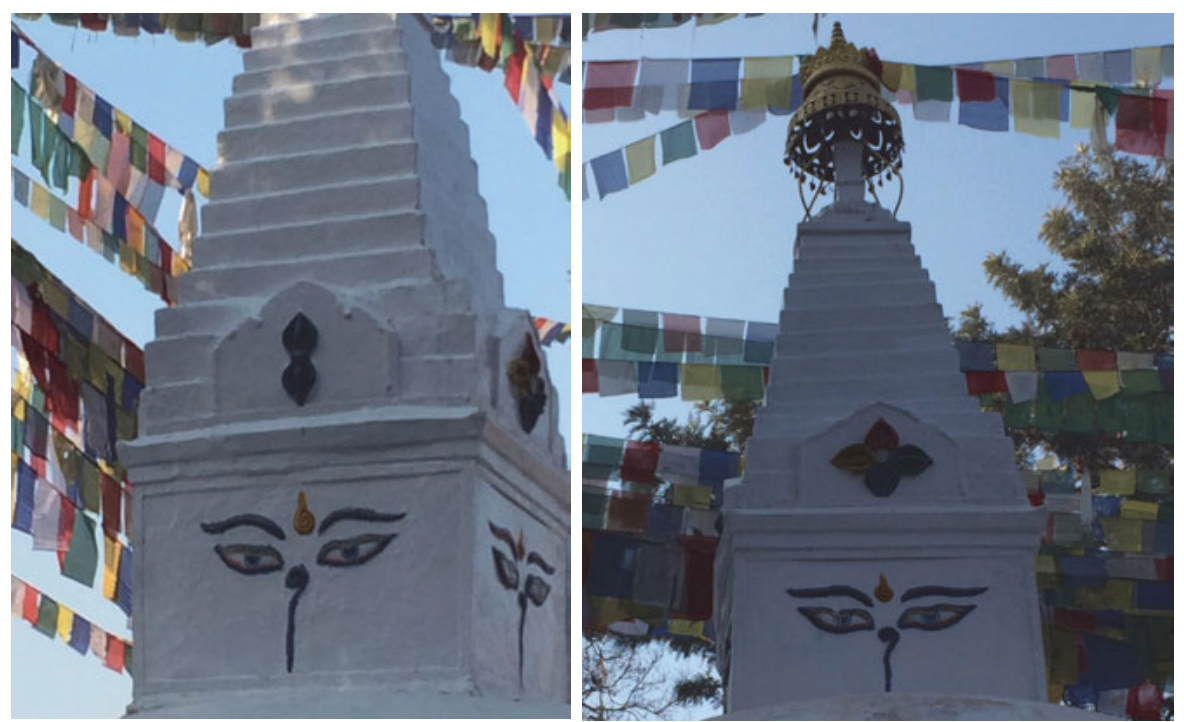

Fig. 3.6.2.1.6-XXXI: Florally stylised vajra (left) and viśvavajra (right) on the pillar of one of the stūpas at Swayambhunath, Kathmandu (image by author 2018)

As mentioned elsewhere, when focusing on the study of palaeography in his book Śākya $(1973,85)$ also presents some symbols in the table. At the top of the table, Sākya informs us that the symbols presented in his table have been 'adapted' from manuscripts, however, he does not tell us from which manuscripts they were adapted. In the second last row of his table there are three florally stylised symbols (Fig. 3.6.2.1.6-XXXII) most likely florally stylised vajras. They are quite similar to the florally stylised vajras in the Buddhist manuscripts presented above. The first sym- 
bol of the last three symbols in the second last row in Sākya's table (Fig. 3.6.2.1.6XXXII) have similarities to the symbols in the manuscript of the Lañkāvatāra, ${ }^{343}$ on 13v3, $162 \mathrm{v} 6$ (see Fig. 3.6.2.1.6-XX) and in the manuscript of the Samādhirājasūtra, ${ }^{344}$ on $87 \mathrm{v} 3$ (see Fig. 3.6.2.1.6-XXI). The last two symbols in the second last row in Sākya's table are quite similar to symbols found in the manuscript of the Gaṇdavyūha, ${ }^{345}$ on 288v4, 289v4 (see Fig. 3.6.2.1.6-XXV).

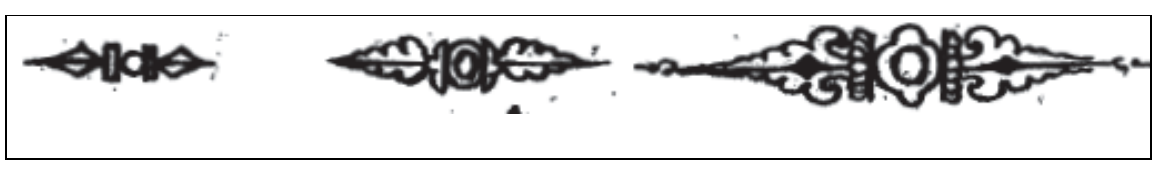

Fig. 3.6.2.1.6-XXXII: Extracted last three symbols from the second last row from the table of Śākya (reproduced from Śākya 1973, 85)

The last three symbols in the last row of the same table of Śākya $(1973,85)$, appear to be floral types. These symbols may be interpreted as representations of florally stylised dhvaja or chattra for these kinds of symbols appear in paper Buddhist manuscripts, similar to the manuscript of the Gandavyūha ${ }^{346}$ on $289 \mathrm{v} 4$ (see Fig. 3.6.2.1.6-XXV) and in an MTM containing Buddhist texts ${ }^{347}$ on $74 \mathrm{v} 5$, 74v9 (see Fig. 3.6.2.1.6-XXVIII). Thus, we can assume Sākya probably adapted these florally stylised symbols and the aforementioned florally stylised vajras from the Buddhist manuscripts too.

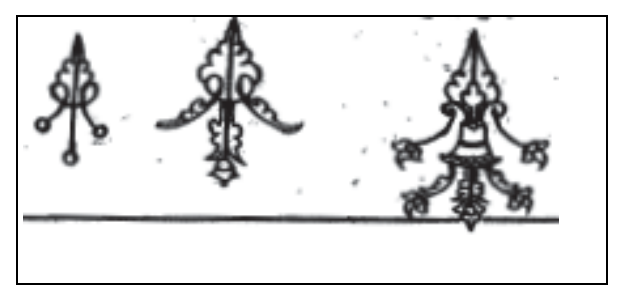

Fig. 3.6.2.1.6-XXXIII: Extracted symbols from the last row of Śākya's table (reproduced from Śākya 1973, 85)

343 See NAK 3/610 / NGMPP B 88/2.

344 See NAK 3/611 / NGMPP B 94/1.

345 See NAK 5/75 / NGMPP A 110/3.

346 See NAK 5/75 / NGMPP A 110/3.

347 See NAK 4/1381 / NGMPP A 126/4. 


\subsection{Symbol in PV}

PV is kept in the NAK. There is no further information about the place of copying and scribal activities mentioned in the manuscript. On the possibilities of place of production, one may assume that it may have been copied by a 'Jaina' scribe in a certain place in the Gujarat or Rajasthan regions and later brought to Nepal. It is also possible a 'Jaina' scribe copied the text in Nepal, ${ }^{348}$ or a Nepalese scribe familiar with Jaina writing customs, copied the text in Nepal or in the Gujarat or Rajasthan regions after which the manuscript was brought to Nepal. Based on palaeographical grounds and according to layout- and symbol-related evidence I have grouped this manuscript for the present book in Western India.

In this manuscript at the chapters's end we find (and also at the end of some smaller text units) mostly 'cha' symbols ${ }^{349}$ (type no. 47) and, occasionally, some stylised puṣpikās $\mathrm{s}^{350}$ (see Appendix below). Stylised puṣpikās also appear around string-holes on almost all folios (see section 3.6.1 above for more detail).

On the first line of $89 \mathrm{v}$ is a simple svastika ${ }^{351}$ symbol which seems to be of a particular importance. Here it is a vāmāvarta svastika ('a left-facing svastika'). The symbol appears in the middle of a sentence in the $26^{\text {th }}$ chapter, about the nandyāvartakakarana, on the 'Nandyāvartaka measure (for query analysis)'. ${ }^{352}$ As we know, the nandyāvarta symbol is one of the eight auspicious symbols in Jainism, ${ }^{353}$ belonging particularly to the Śvetāmbara ('white-clad') tradition. In PV the svastika is integrated into the text and is situated within the explanation on the shape of the nandyāvarta symbol. It is followed by the svastikavad bha$v a t i \mid$ (see the part of the transcribed text before and after the svastika below).

348 On this topic, see Acharya 2007, 4.

349 For instance, on 10r4_B/ACC, 10v5_BCC, 14r5_BCC, 18r4-5_B/ACC, 18v5_B/ACC, 24v2_BCC, 30v1-2_B/ACC, 36r3-4_B/ACC, 39r2_B/ACC, 41v1_ACC, 48r3-4_B/ACC, 50v5-51r1-2_B/ACC, 52r34_B/ACC, 64r1_ACC, 64r5-6_ACC, 65r1-2_ACC, 66r4-5_B/ACC, 66v3-4_ACC, 67r_ACC, 67v2_ACC, 71v1-2_B/ACC, 74r5_B/ACC, 75v2-3_B/ACC, 80v3-4_B/ACC, 87r5_B/ACC, 105v1-2_B/ACC, 115r45_B/ACC, 117r2_B/ACC, 120v2-3_B/ACC, 131r3_B/ACC, 136v3-4_B/ACC, 137r5_B/ACC, 138v34_B/ACC, 147r5_B/ACC, 149r3_AC, 149r3_AAL, 149v3_BI.

350 Namely on 10v6_ACC, 14r5_ACC, 24v2_ACC, 41r3_ACC, 44r2_ACC.

351 The Svastika can be used as insertion sign in manuscripts (Thaker 2000, 146). In some of the manuscripts in my corpus, the svatika is also used as an insertion mark e.g. on 147v in SS/N, on $105 \mathrm{r6}$ in NTS, on $83 v 4$ in $\mathrm{Aṣ}_{2}$. In $\mathrm{SP}_{4}$ the svastika was used one time as an indicator sign for the deletion on 10v5 and as an insertion mark on 11r in line 1 and 4; see also Roth 1986, plate 1, 21, 23 for svastika symbols.

352 See Acharya 2007, 8.

353 See Moeller 1979, 149-154; on eight auspicious symbols, see also at: <http://www.jainpedia. org/themes/principles/holy-symbols/eight-auspicious-symbols.html> (last accessed on 06.10.2018). 
Fig. 3.6.2.1.7-I: Svastika in a particular place, fol. 89v @ NAK

[89v1] $k a\|\odot\| s m a \bar{t}$

svastikavad bhavati | sa naṃdyāvartta(!) dvidhā bhavati |

'How can it be like a svastika? The namdyāvartta is twofold.'

Palaeography and its appearance indicate the svastika symbol could have been drawn by the same scribe who copied the text. It is safe to assume the scribe had knowledge of what he was writing with the svastika symbol appearing just before the expression 'svastikavad'. The scribe may have drawn the svastika deliberately to visually reinforce textual explanation.

\subsubsection{Selected examples of puzzling symbols in manuscripts}

Some manuscripts contain symbols interesting in appearance which at the same time are puzzling for their drawing effect. This section presents a few symbols from selected manuscripts.

KT

Among other symbols, ${ }^{354}$ in KT, there are those with an interesting and puzzling appearance. On $78 \mathrm{r} 7$ before and after the chapter colophon there are symbols like a 'leaf' or leaf-like element (see Fig. 3.6.2.2-I). Both symbols have a dot at their centre. Before the chapter colophon on $68 \mathrm{v} 7$ and after the chapter colophon on $69 \mathrm{v} 5$ other puzzling types of symbols with an 'eye' or eye-like features. After the chapter colophon on 68v7 the symbol looks like a 'bird' or bird-like element. Here it may be a representation of a Garuda because after the symbol there is a speaker indication as follows: garuda uvāca ('Garuda said'). All of these symbols are lightly highlighted. Some other symbols and features of this manuscript have been discussed above in section 3.6.2.4.1 and below in section 3.9.3.

354 For instance, circles (type no. 2), double circles (type no. 6), some stylised puṣpikās (type nos. $8,9,14,22,23)$. 


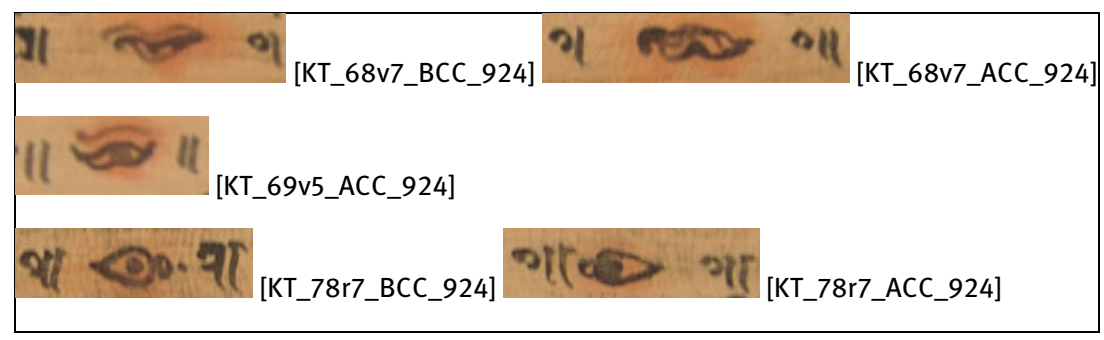

Fig. 3.6.2.2-I: Puzzling symbols before and/or after the chapter colophons

\section{PR}

Among other symbols, ${ }^{355}$ in PR we find stylised 'half-like' puṣpikās on 15r5, 16r5, 19r5, 45r5 that appear after and/or before the chapter colophon or before the concluding Buddhist formula, or before the invocation etc. ${ }^{356}$ Some of them are a little over half-size (as with 19r5), but look to be precisely 'half'. These symbols fulfil similar functions to the full type of symbols in the manuscript. In the inner part of one of the stylised 'half' pusppikās that appears after the concluding formula on 19r5 there is a kind of realistic pusppika with buds, on the left and right side, at the sprouting stage. The inner part of the symbol could be interpreted to be a padma representation. ${ }^{357}$ Another puzzling type of symbol appears before the chapter colophon on 19v1. This symbol consists of an arrow-like element at the centre part and two elements resembling one of the letter-numerals for

355 For example, stylised full puṣpikās on 19v1, 20v1, 64v3-5, 67r2, 70r3, one stylised simple puṣpikā on 64v3 (type no. 16), one circle on 67r2 (type no. 2), circle with curved line in the centre part on 54r2, 54r3, 56v3, 56v4, 56v5, 57r1, 57r2, 57r4, 61v1, $70 \mathrm{r6}$ (type nos. 4 and 5), spiral-like symbols on 55r1, 55r2, 61v3, 61v4, 62r1, 63r2, 63r3, 63r4, 63v1, 63v3, 64r5) and thas on 54r3, 55r1, 56v3, 58r1, 58v3, $61 \mathrm{v} 5,62 \mathrm{v} 3$ (type no. 46) can be found at the end of the chapter, beginning of smaller text units, mantras and invocations in the manuscript.

356 Similar types of stylised 'half-like' puspikās can also be found before or after the chapter colophons on 18r7, 26v6, 77v7, 98v7, 144r7, 158r7 in the Nepalese manuscript of the Aștasahasrikā Prajñāpāramitā (NS 268 / 1148 CE) (Museum für Asiatische Kunst, Berlin, I 5410 \& I 5411 and Asiatic Society, Calcutta, G.4203), see Melzer /Allinger 2010, 6-7. Furthermore, one half-like stylized puṣpika appears after the chapter colophon in the manuscript of the Tinbheda (NAK 4/257 / NGMPP B 36/2) on 48r2.

357 Also in the inner part of one example of 'full' symbol in the manuscript of the Astasahasrika Prajñāpāramitā (ca. $11^{\text {th }}$ c.) (Bodleian Library, Oxford, Ms Sansk. a 7(R)) at the end of the $11^{\text {th }}$ chapter one can observe a realistic type of puspikā, see Weissenborn 2012, 198, Abbildung 70(c). This realistic type of puspika may also be understood as a padma. However, with its somewhat open petals the pușpikā here appears fully-fledged. 
'50,358 with an extra small stroke on the upper and lower sides. In this context the symbol is perhaps an abstract representation of the vajra or similar item.

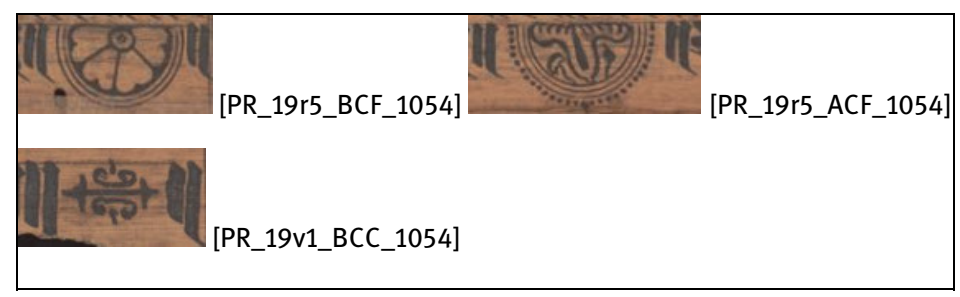

Fig. 3.6.2.2-II: Puzzling symbols

\section{Manuscript of the Ratnakaranḍikā (KL 522 / NGMPP C 49/1)}

In the manuscript of the Ratnakaraṇdikā (NS 299 / 1179 CE) (KL 522 / NGMPP C 49/1), there are two finely formed symbols exhibiting a puzzling effect of drawing skills. One of the symbols appears before the chapter colophon on 81v1 and the other after a chapter colophon on $165 \mathrm{r} 3$ (see Fig. 3.6.2.2-III). Both symbols are quite uniquely drawn. They contain four 'half-like' stylised puspikās on the upper, lower, left and right side. ${ }^{359}$ But if we combine the lower element with the upper element or the other way round we get a 'full' stylised puspikā (see the first row of the second column in Fig. 3.6.2.2-IV). Similarly if we combine the left element with the right element or the other way round we get another full stylised puspikā (see second row of the second column in Fig. 3.6.2.2-IV) ${ }^{360}$ Furthermore, if we look closely at the both symbols on $81 \mathrm{v} 1$ and $165 \mathrm{r} 3$ there is something interesting at their centre. There is a stylised puspikā containing four petals or leaf-like elements in both symbols. This is expressed graphically by leaving the undrawn space at the centre of the symbols.

358 For the letter-numeral ' 80 ', see Bendall 1883, Table of Letter-numerals, row 5.

359 For instance, attestations of nearly identical 'half-like' symbols similar to this facing side up can be found in the manuscript of the Viṣnudharma (1161 CE) (NAK 4/1389 / NGMPP A 10/3) on 20r1_B/ACC, 53r5_ACC, 88r5_BCC, 106r6_BCC, 133r6_ACC; in another manuscript of the Viṣnudharma (1220 CE) (NAK 2/51 / NGMPP A 1163/1), IndoSkript, symbol, IS-Nr: 191.

360 After joining the left and right elements we get near similar symbols listed in type no. 29 above. 


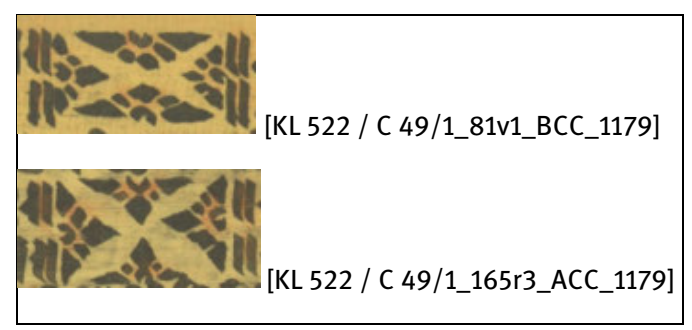

Fig. 3.6.2.2-III: Puzzling symbols before and after the chapter colophons

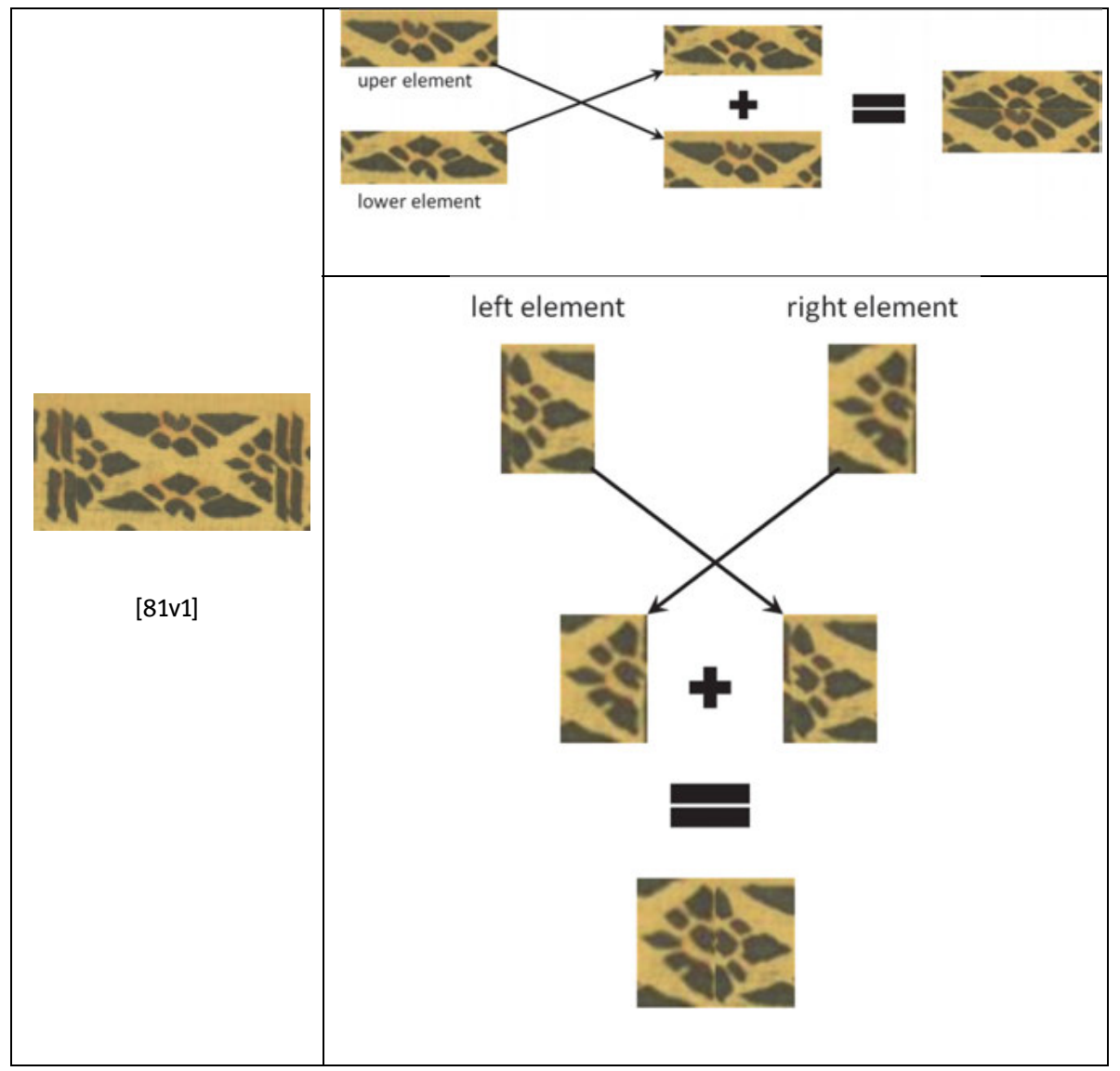

Fig. 3.6.2.2-IV: Illustration of puzzling symbol, on fol. 81v1 


\section{VDh}

In VDh there are different kinds of symbols. ${ }^{361}$ Some exhibit puzzling features, see 19v5, 140v3 and 140v4. After the chapter colophon on 19v there is a puzzling style of symbol with appearance of a kind of hook. At the centre of this symbol is a circle. Two symbols before and after the chapter colophon on $140 \mathrm{v}$, the second $^{362}$ looks like a kind of 'larval stage of butterfly' or 'moth-like insect' and the first has other elements on its sides like the form of butterfly or a later development of the larval stage from the previous symbol.

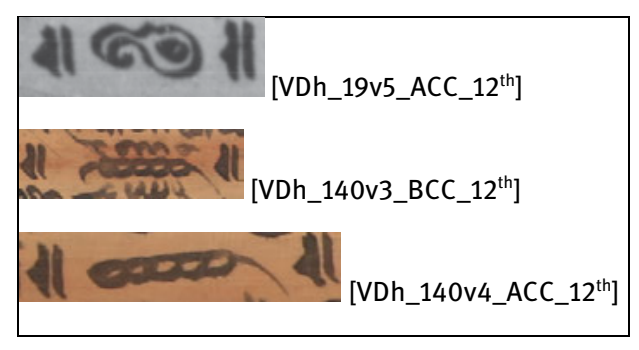

Fig. 3.6.2.2-V: Puzzling symbols before and/or after chapter colophons

\section{STT}

Circles predominate after chapter colophons in STT save for one symbol on 5v7. The symbol on $5 \mathrm{v}$ consists of ' $u$-like' two elements placed together and both contain a tail-like line. Yet another component is to be seen between the ' $u$-like' elements.

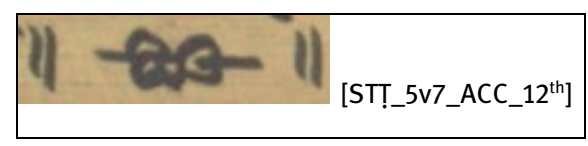

Fig. 3.6.2.2-VI: A puzzling symbol after the chapter colophon

361 See the three circles on 20v3_ACC, 51v5_BCC, 122r2_ACC (type no. 2), a variety of stylised simple puṣpikās such as type nos. 6, 12, 14, 16, 17, 18, 19, 31, some beautifully drawn stylised puṣpikās (see section 3.6.2.4.1). For other symbols see Appendix.

362 Similar symbols appear before and/or after chapter colophons on 138r3, 139v2, 143r2, 143r2, $150 \mathrm{v} 5$. This type of symbol is also used as space-filler in the manuscript, as at the bottom of 139v5, $140 \mathrm{r} 5$. 


\subsubsection{An observation: Creation of symbols in $\mathrm{SP}_{3}$}

By making use of or re-using a certain symbol more than once a scribe could well be demonstrating his drawing skills and practice through his manner of implementing symbols in a manuscript. While doing so he may introduce new symbols, forms or varieties of symbols lending them a more sophisticated and elegant appearance. To this end he may use or reuse a particular symbol repeatedly adding other elements to the symbol or utilising a specific symbol as part of a new symbol. This section presents selected symbols of $\mathrm{SP}_{3}$ and discusses how, when drawing symbols in the manuscripts a scribe may use his craftsmanship innovatively.

In Fig. 3.6.2.3-I the first symbol has a circle at its centre surrounded by four petals and four lines (on 44r6). ${ }^{363}$ However, the second symbol is comprised of the first symbol with three additional petal-like elements on the left and right sides (on 106r6).

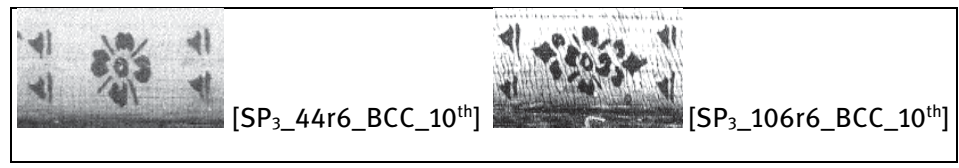

Fig. 3.6.2.3-I: Use and reuse of symbols

The first symbol consists of one circle at its centre and five petal-like elements at the sides (on 83v6). ${ }^{364}$ The second symbol, however, is composed of a near similar symbol to the first, placed at the centre with additional circles and petal-like elements (on 171v2).

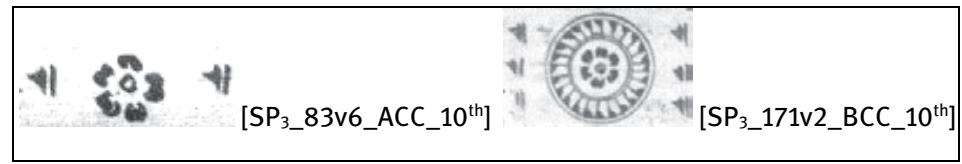

Fig. 3.6.2.3-II: Use and reuse of symbols

363 More near identical symbols appear in the manuscript on 31r1_ACC, 37v_ACC, 106r6_ACC, 123r6_BCC, 125v2_ACC.

364 A near identical symbol appears in the manuscript on 164r3_ACC. See type no. 11 in section 3.4 above. 
The first symbol consists of one circle at its centre and a few petal-like elements on the sides (on 18r5). ${ }^{365}$ But the second (on 165v1) and third symbols (on 171v2) are near similar to the first including a quite attractive use of concentric circles and other additional features.

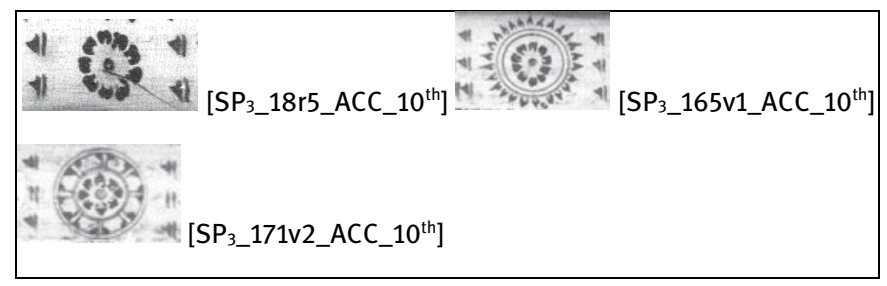

Fig. 3.6.2.3-III: Use and reuse of symbols

The first symbol consists of double circles at the centre surrounded by a few petal-like features (on 193r5). ${ }^{366}$ The second symbol, however, is made out of the first symbol adding three petal-like elements on the left and right sides (on 24v5). ${ }^{367}$ Following this the third symbol is made up of the first symbol with many other additional petal-like elements on its outer sides (on 69r4). The symbol has the shape of a kind of 'rhombus'. The fourth symbol is composed of the first with additional petal-like features resembling a kind of 'square box' (on 146r4). The next symbol consists of the first with more petal-like elements added to each of its four corners (on 176v3). Likewise, the symbol afterward is composed of the first with double circles and other features added (on 166v1).

365 Other near similar symbols can be found in the manuscript on 18r5_ACC, 46v5_ACC, 60r6_BCC, 198r4_BCC.

366 Other near similar symbols appear in this manuscript on 138r5_BCC, 159r3_ACC, 186r1_ACC, 193r5_BCC, 198r5_ACC, 244v3_ACC, 246r1_BCC. See type no. 24 in section 3.4 above. 367 An almost identical symbol is also drawn on 168v5_BCC. 


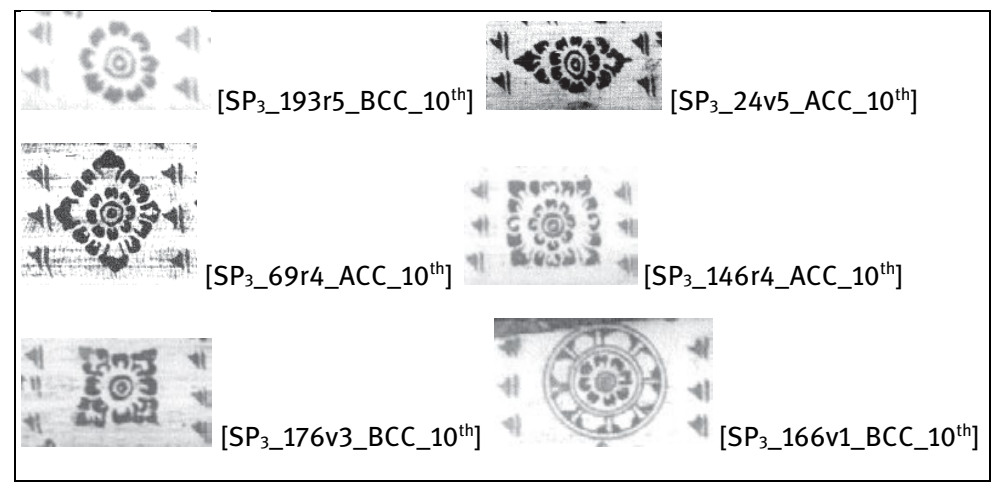

Fig. 3.6.2.3-III: Use and reuse of symbols

The first symbol contains a circle at its centre surrounded by some petal-like features (on 46v5). ${ }^{368}$ It has a kind of 'rhombus' shape. The second symbol is composed of the first using with other elements, e.g. double circles and many petal-like features on the outer side (on 180r1).

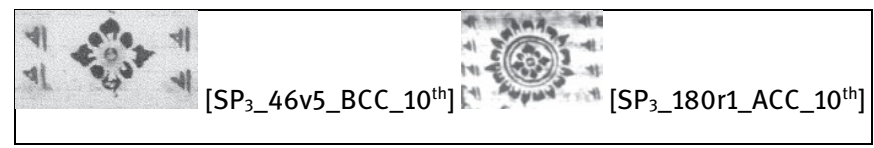

Fig. 3.6.2.3-IV: Use and reuse of symbols

The first symbol is made of double circles and more petal-like elements on the outer side (on 20v3). The second symbol, however, is composed out of the first symbol with the addition of small petal-like elements between the 'main petals' (on 54v4). ${ }^{369}$ The third symbol is somewhat similar to the second, but encircled by concentric circles (on 162r2).

368 See type no. 28 in section 3.4 above.

369 Other almost identical symbols appear in the manuscript on 24v5_BCC, 27r5_ACC, 44r6_ACC, 56v4_ACC, 148v4_BCC, 150v5_ACC, 168v5_ACC, 200v4_ACC. An identical symbol can also be found in the manuscript of the Sivadharmaśāstra (1037 CE) (Calcutta, ASB G-4077), IndoSkript, symbol, IS-Nr: 243. 


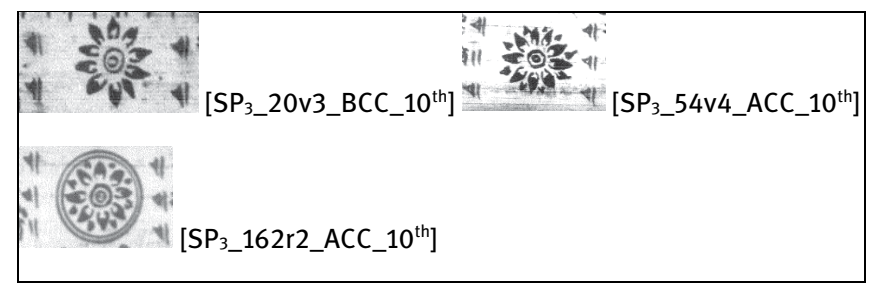

Fig. 3.6.2.3-V: Use and reuse of symbols

The first symbol contains eight petals with dark shadow-like elements at its centre resembling additional petals or petals of two different colours (on 76r2). ${ }^{370}$ They are encircled. The second symbol is made of the first symbol or a few elements of the first with other additional features and circles outside (on 133v4).

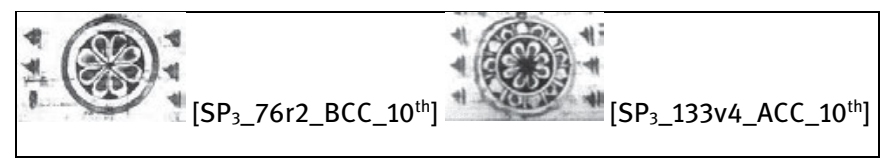

Fig. 3.6.2.3-VI: Use and reuse of symbols

The first symbol is made of eight petals, double circles and a circle on its outer side (on 147v4). The inner parts of the second (on 23r1) and third symbol (on 145r4) are composed of the near similar symbol to the first with other elements added to the outer side.

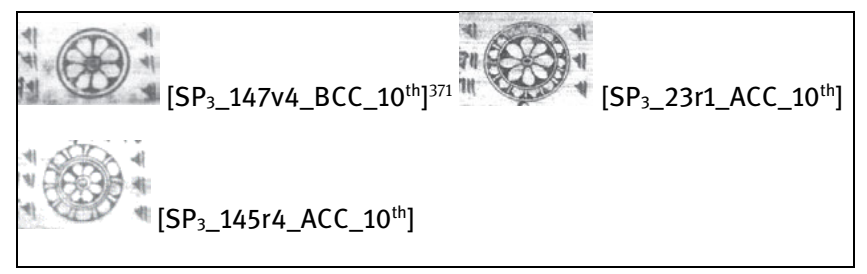

Fig. 3.6.2.3-VII: Use and reuse of symbols

370 Three other almost similar symbols appear in the manuscript on 74v2_B/ACC, 76r2_ACC. 371 A few similar symbols appear in the manuscript, see 112v2_BCC, 127r1_BCC, 147v4_BCC, 165v1_BCC and in $\mathrm{SP}_{4}$ on 5r1_ACC. 
The first symbol has double circles in the centre, twelve petals and outer circles (on 60v1). Compared to the petals of preceding symbols (see Fig. 3.6.2.3-VII), the symbol's petals are thinner, and their outer edges are slightly sharper. The second symbol uses nearly the same symbol to the first with additional elements on its outer side (on 114r4).

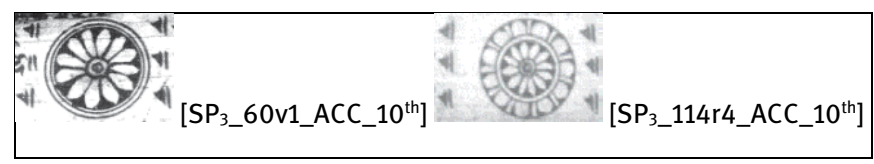

Fig. 3.6.2.3-VII: Use and reuse of symbols

The first symbol has double circles at its centre with four lines and four petals on its sides (on 147v4). The petals have additional elements at the centre. They may have been used to represent the different colours or blemishes found in the petals of real flowers. The second symbol is composed of the almost identical petals to those in the first symbol (on 133v4).

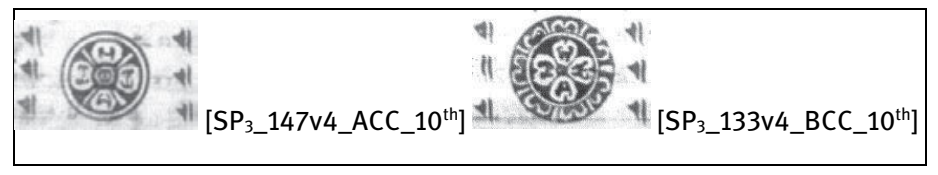

Fig. 3.6.2.3-VIII: Use and reuse of symbols

The first symbol has four 'heart-shaped' petals and circles at its outer side (on 109v2). ${ }^{372}$ The second has four similar types of heart-shaped petals, but with additional features at its outer side (on 103v1).

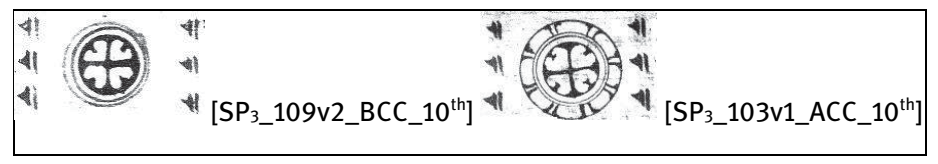

Fig. 3.6.2.3-IX: Use and reuse of symbols

372 See type no. 38 in section 3.4 above. 
The first symbol consists of eight heart-shaped petals and concentric circles at its outer side (on 32v4). The second symbol is almost similar symbol to the first, but with additional elements at its outer side (on 32v3).

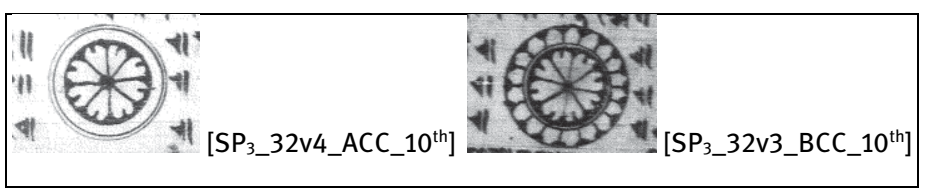

Fig. 3.6.2.3-IX: Use and reuse of symbols

\subsubsection{Symbols used to mark hierarchies in texts}

As mentioned above, some manuscripts contain a great variety of symbols. Some symbols are of a very decorative style, whereas others are quite simple. The size is of particular importance as a symbol may occupy the equivalent to a single line or be the height of the entire written section of a folio from top to bottom. For their complexity and quality the distribution of these symbols may occasionally indicate the various hierarchical levels of the sections of a text.

The frequency of symbols on the folio can also be relevant. Symbols occur before and/or after a chapter colophon. However, at the end of a particular text, there may be a series of many symbols.

\subsection{Shape, size and distribution: Symbols at the end of chapters and at the end of the text in selected manuscripts}

This section indicates the pattern characterizing the shape, size and distribution of symbols largely featuring at the end of chapters and the entire text.

KT

There are various kinds of symbols at the end of the chapters in KT, circles (type no. 2), double circles (type no. 6), stylised puspikās (with a circle, four petals and four lines) (see, type nos. 8, 9, 14, 22, 23) and some, still rather puzzling symbols (see section 3.9.3). All symbols occupy the space of one line only on the folio (e.g. the symbols at the end of the $7^{\text {th }}$ chapter on $13 \mathrm{v} 4$ and the $54^{\text {th }}$ chapter on $82 \mathrm{r} 2$ ). However, at the end of KT on 99r2-3 after the colophon, there are two slightly larger symbols that differ in shape from those appearing at the end of chapters. 
The size of the first symbol (on 99r2) occurring after the statement providing the date of the manuscript's copying, is an area of two lines of the folio. The symbol is followed by a benediction phrase followed by a statement providing the donor's name (Udayapālasoma) and place of copying (Bhaktapur). Compared to the symbols at the end of the chapters, both symbols are of a clearly different form, but appear like a later addition or redrawing. The first symbol (on 99r2) has double circles in the middle part surrounded by a few petal-like elements. ${ }^{373}$ The second symbol (on 99v3) also contains double circles at the centre but the circles are surrounded by wavy petal-like elements, drawn in a quite different shape. Regarding the latter it may be that the symbol consisted originally of only double circles and the additional elements were added later.

[13v4] | iti kiraṇākhye tantre|ఠ| saptamah pațalah

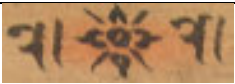

[82r2] || iti kiraṇākhye mahātantre catuḥpañcāśat pațalạ̣ || ślokā 71

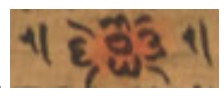

Fig. 3.6.2.4.1-I: Symbols at the end of the chapters

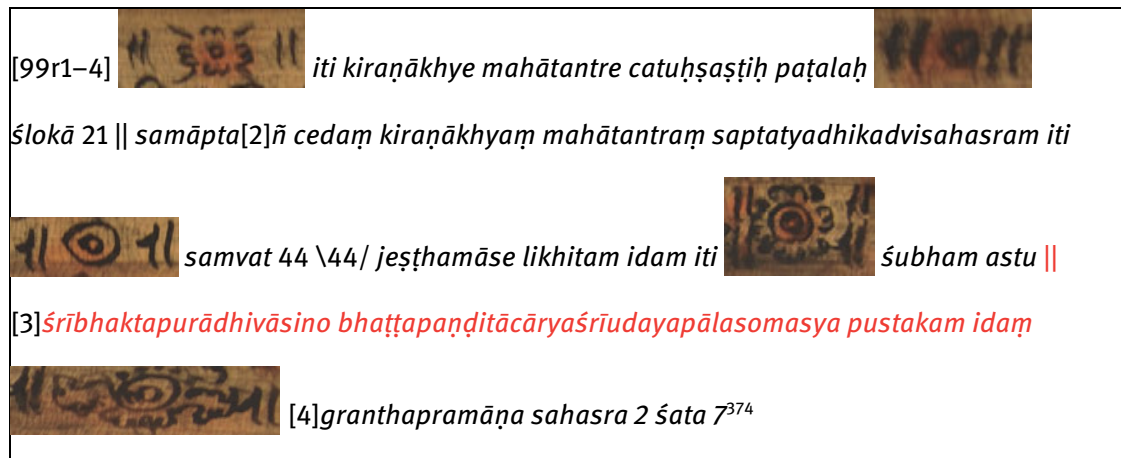

Fig. 3.6.2.4.1-II: Symbols at the end of the $64^{\text {th }}$ chapter and end of the text

373 See section 3.4, type no. 24 above.

374 For this textual part, see also Shastri 1915, 99; Goodall 1998, lxxxiv. 


\section{VDh}

In VDh there are various kinds of symbols at the end of the chapters. The height of the symbols is one to two lines of the folio (e.g. symbols at the end of one of the chapters on 36r1 occupy an area of one line and at the end of one of the chapters on 62r5 symbols occupy two).

However, at the end in VDh on 160v, there are four nicely drawn symbols. Of these, two symbols accompanied by the colophon are much larger, their height is over half that (top to bottom) of the folio. Both symbols are of a far more attractive form to the other symbols at the end of the chapters.

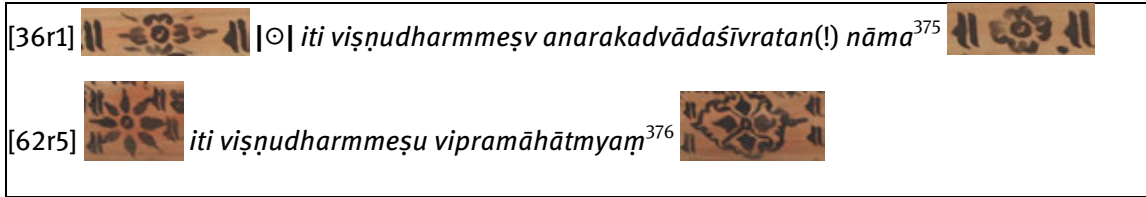

Fig. 3.6.2.4.1-III: Symbols at the end of the chapters

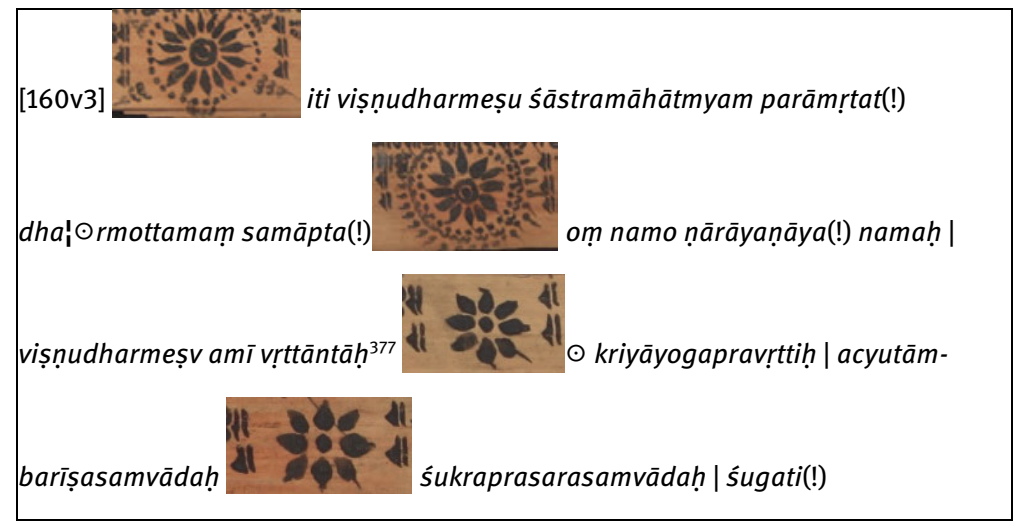

Fig. 3.6.2.4.1-IV: Symbols at the end of the text

375 Grünendahl 1983, 144 reads the line as iti viṣnudharmeșu narakadvādaśī nāma.

376 For the line, see also Grünendahl 1984, 78.

377 For this textual part, see also Grünendahl 1983, 16. 


\section{AĀ̄}

There are almost no stylised puspikās at the end of the chapters in this manuscript save for one simple stylised pușpika at the end of the $32^{\text {nd }}$ chapter (on $164 \mathrm{v5}$ ) and some siddham symbols (e.g. on $84 \mathrm{v} 5$ ). ${ }^{378}$ The symbol at the end of the $32^{\text {nd }}$ chapter has one circle at its centre surrounded by larger circles; the height of the symbol is two lines of the folio. Aside from these, 'blank spaces' feature usually at the end of chapters. ${ }^{379}$

However, at the end in AAĀ on $165 \mathrm{v}$, there are two nicely drawn stylised pusspikās. The folio features only four lines thus most of the lower part of the folio is blank, save for the remaining part of the space that has the two symbols in line no. 3. Originally both symbols were accompanied by a line providing the name of the author (Haribhadra). However, before the author line, the colophon (see below) has been added by means of an insertion mark. The handwriting of the other lines on the folio, appears to be different to the handwriting of the colophon. Both symbols appear larger, at more than half of the height (top to bottom) of the folio and have been placed between five sets of double dandas. Their shape and size are identical. After the second symbol, the verse 'ye dharmā ...' can be found (in line nos. 3-4) followed by a siddham symbol.

378 On 35r3_BCC, 48v4_BCC, 61r_BCC, 79r7_B/ACC, 83r3_BCC, 84v5_BCC, 93v2, 96r4_BCC, 104_B/ACC, 123v7_BCC, 127r6_BCC, 132r2_BCC, 134r4_BCC, 135v6_BCC, 144r1_B/ACC, 156v1_BCC, 165v4_ABV) (type nos. 44, 45). See also section 3.4, Fig. 3.4-XLIV and section 3.5.2 above.

379 On 35r3_ACC, 48v4_ACC, 61r3_ACC, 64r1_ACC, 66v4_ACC, 74r5-6_B/ACC, 78r2_B/ACC, 83r3_ACC, 84v5_ACC, 88r5_B/ACC, 93v2_ACC, 96r4_ACC, 102r2_B/ACC, 103v2-3_B/ACC, 108r2_B/ACC, 119r3_B/ACC, 123v7_ACC, 127r6_ACC, 132r2_ACC, 134r4_ACC, 135v6_ACC, 139r3_ACC, 141r5_ACC, 147v7_ACC, 156v2_ACC, 159r7_ACC, 164r2_ACC. See also section 4.1.2 below. 


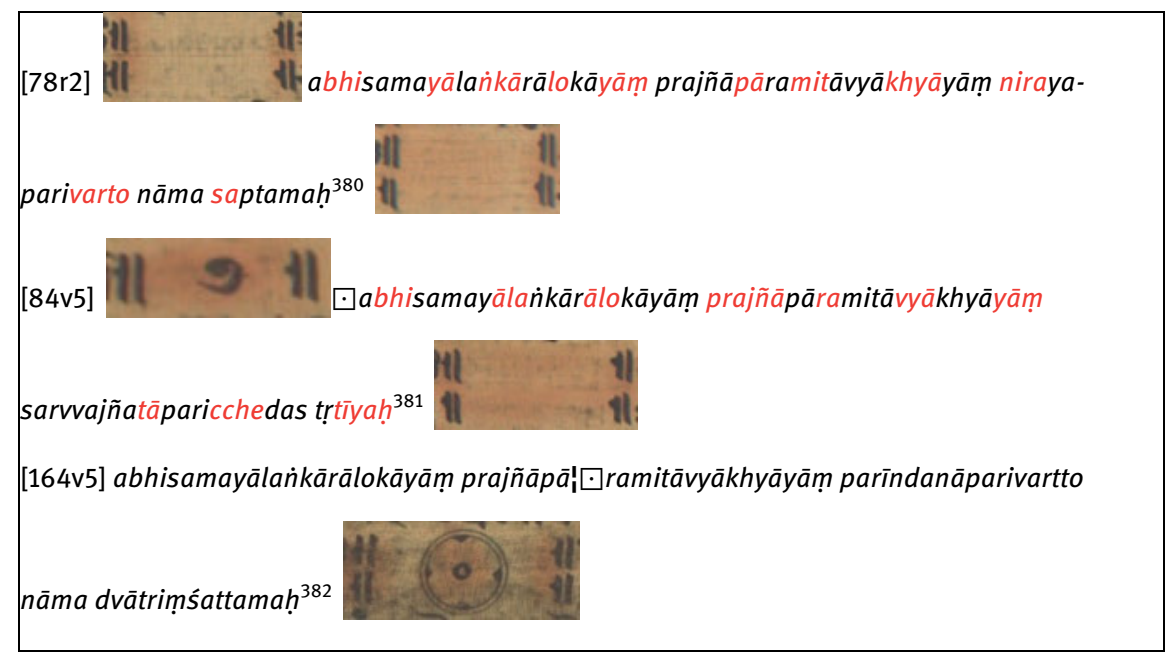

Fig. 3.6.2.4.1-V: Symbols and blank spaces at the end of the chapter

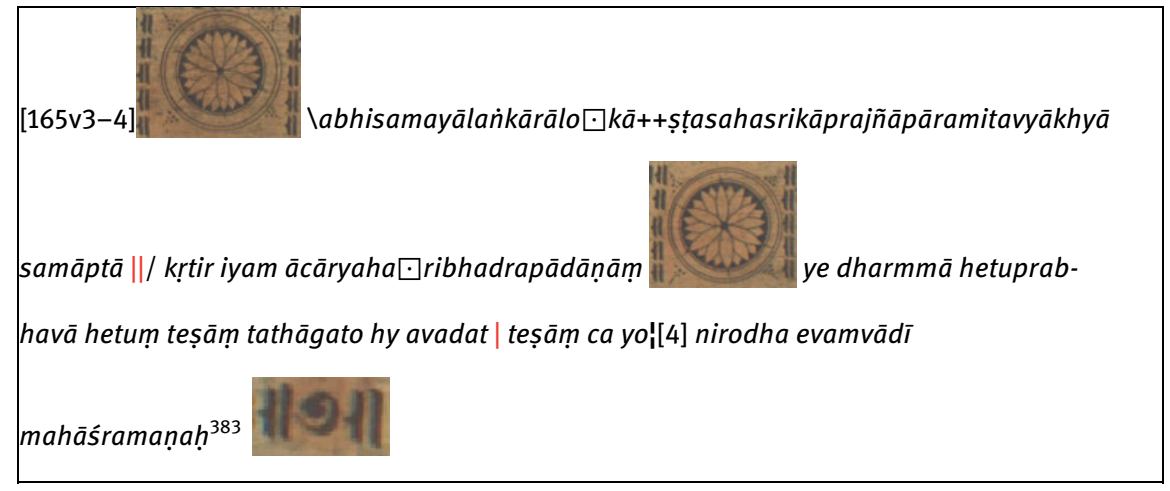

Fig. 3.6.2.4.1-VI: Symbols at the end of the text

380 For the line, see also Tucci 1932, 261.

381 For the line, Ibid. 285, footnote 1.

382 For the line, Ibid. 562.

383 For some part of the textual part, Ibid. 564. 


\section{TSPV}

There are 'cha' symbols at the end of the chapters in TSPV (type no. 47, mostly before chapter colophons) and some stylised pusspikās (always after chapter colophons) which are simple in shape (see 253?v8). However, at the end of the text on 313v2 stylised puspikās appear which, compared to the symbols appearing at the end of the chapters (e.g. on 150v2 and 253?v8), are significantly more attractive in shape and their distribution sequence is different. The symbols at the end are always surrounded by cha symbols. The first, second and third stylised puṣpikās are placed between cha symbols. After the second stylised puṣpikā, a benediction statement (mañgalam mahāśrīh, 'auspiciousness [and] great prosperity') is followed again by another stylised puṣpikā placed between the cha symbols. This too is followed by a statement of benediction (śubham bhavatu, 'may there be auspiciousness') and two stylised puṣpikās have been placed between the three cha symbols.

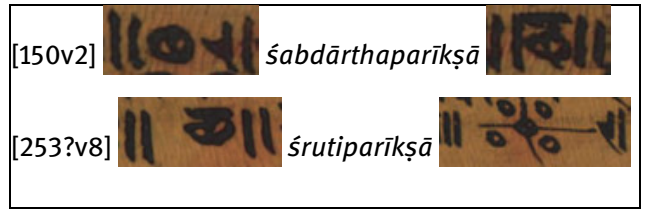

Fig. 3.6.2.4.1-VII: Symbols at the end of the chapter

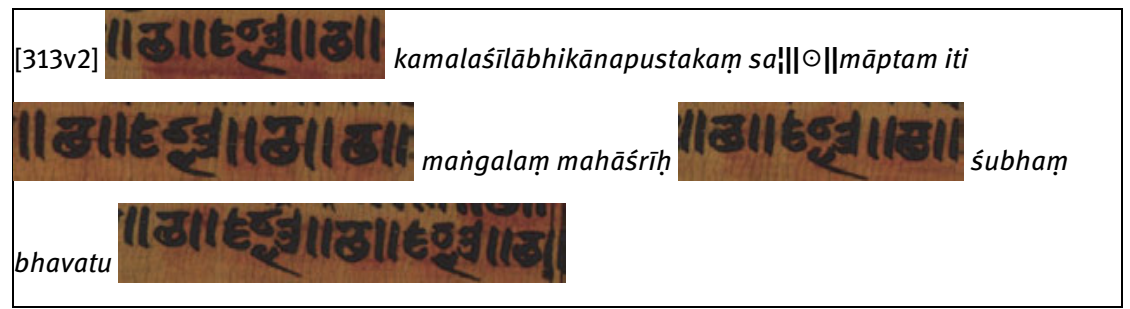

Fig. 3.6.2.4.1-VIII: Symbols at the end of the text 


\section{SDhPS}

There are a few circles, ${ }^{384}$ 'tha' symbols ${ }^{385}$ (e.g., on 58v2), a 'figure-eight knot' symbol (on 43v5_ACC), and some simple and beautiful stylised puṣpikās (e.g., on 79r3) (which could be understood as double vajra) ${ }^{386}$ in the manuscript. All of the symbols at the end of the chapters are a height of one to three lines of the folio.

However, almost at the end of the text on 138v, 139r and 139v there are a series of three nicely drawn large symbols ${ }^{387}$ (see the three symbols on the last folio on $139 v)$. Each of the three symbols appears at the centre of every text-section. All symbols are almost the entire height of the folio (top to bottom). Compared to the symbols at the end of chapters, the symbols on 138v, 139r and 139v are far larger and have a sophisticated form. It is also interesting to note that the symbol at the centre part of the second text-section on $139 \mathrm{v}$ (see below) contains a florally stylised double vajra at its centre.

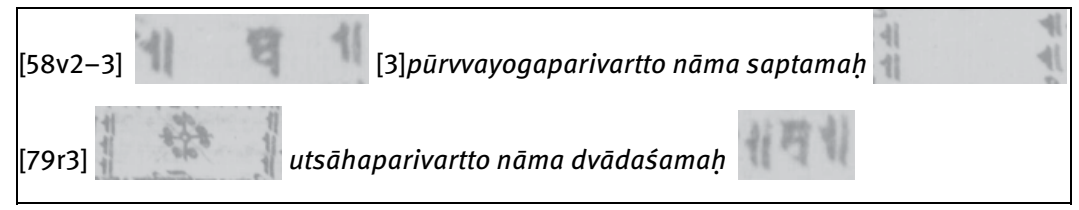

Fig. 3.6.2.4.1-IX: Symbols at the end of chapters

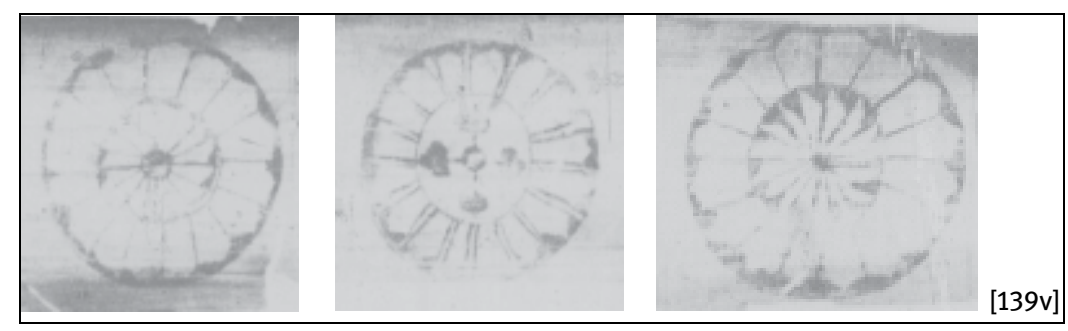

Fig. 3.6.2.4.1-X: Symbols at the very end of text

384 On 100v5_ACC, 106v5_ACC, 116r1_BCC (type no. 2).

385 On 46v6_ACC, 58v2_BCC, 62v4_B/ACC, 79r3_ACC, 84v2_ACC, 89v6_BCC, 93v2_ACC, 100v5_BCC, 113v5_ACC, 134v4_B/ACC (type no. 46).

386 See section 3.6.2.1.5 above.

387 These symbols are discussed below. See section 3.6.2.2.3. 
It can be assumed from the way in which symbols change in terms of size, distribution and decorative value they may be understood as an important visual marker indicating the hierarchy of different parts of a text.

\subsection{Set of symbols at the (very) end of texts in Buddhist manuscripts}

As seen above (in section 3.6.2.4.1) the SDhPS features a series of three large symbols at the (very) end of its text. An almost similar pattern is to be seen in other manuscripts where symbols may or may not be accompanied by a colophon or colophon-like statements.

To the best of my knowledge, one of the oldest existing evidence of this type of distribution is at the end of a birch-bark manuscript of the Dirghägama from Gilgit on 454v (see Fig. 3.6.2.2.3-I below). ${ }^{388}$ The manuscript is in pothi format and thought to date approximately from the second half of the $8^{\text {th }} \mathrm{c} .{ }^{389}$ The manuscript bears one of the crucial texts related to the Mūlasarvāstivāda tradition of one of the schools of non-mahāyānic Buddhism.

A series of three symbols appear at the end of the text at more than half the height (top to bottom) of the folio. All symbols appear identical in size and are not placed between series of double dandas or long vertical lines. Some elements of the symbols look similar e.g. the inner circles or outer concentric circles. The gaps between these circles seem to be identical in size. Of the three symbols, the first symbol appears a few centimetres from the left edge and the second appears almost at the centre of the folio and the third is a few centimetres off the right edge (see examples in Fig. 3.6.2.4.2-I). ${ }^{390}$ The part of the fifth and sixth lines on the folio on which the three symbols appear, read as follows: [5]samā[6]ptaś ca $a_{\sqcup} d \bar{\imath} r g h \bar{a}+m a_{\sqcup} h \|^{391}$ ('[thus], the Dïrghä[ga]ma is also concluded') and indicate the end of the text.

388 See Melzer 2014, 229.

389 For the date, Ibid. 227 and 229.

390 Losty 1982, 29 understands these three symbols as dharmacakras noting 'the Buddhist Wheel of the Law'. As other elements also feature in the inner part of such kinds of symbols, e.g. florally stylised double vajra in a later manuscript from Nepal (see Figs. 3.6.2.4.2-VII and 3.6.2.4.1-X) which also contain a similar way of distributing the three symbols at the end, however, the interpretation of such symbols as dharmacakras remains at the moment unclear.

391 Clearly visible gaps between akșaras are marked using a $\sqcup$ sign in the transliteration. 


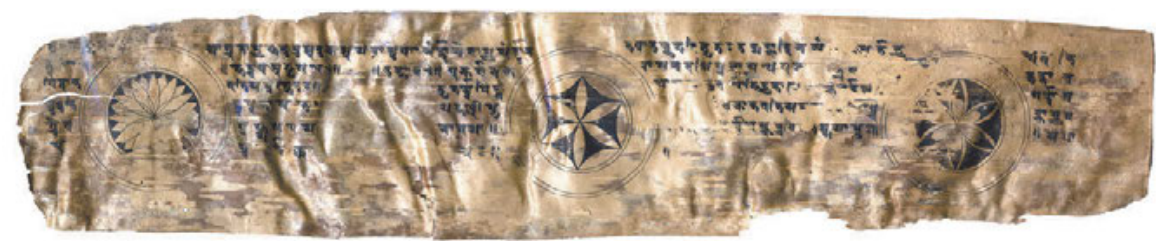

Fig. 3.6.2.4.2-I: A series of three large symbols at the end of the text in the manuscript of the Dīrghāgama, fol. 454v (reproduced from Melzer 2014, 232, Fig. 2)

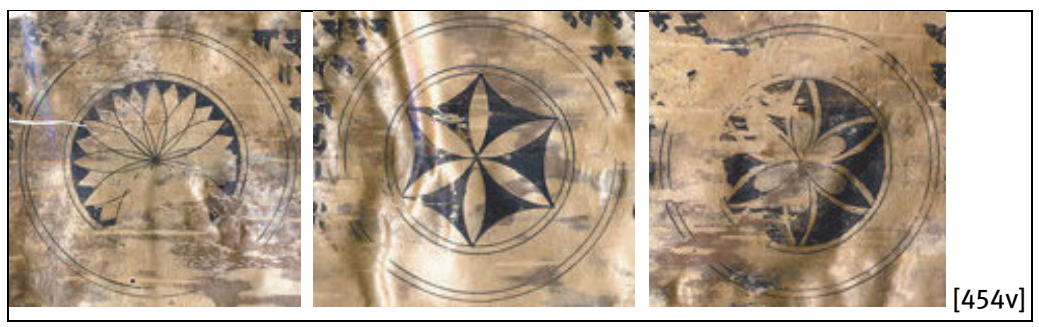

Fig. 3.6.2.4.2-II: Enlarged symbols (reproduced from Melzer 2014, 232, Fig. 2)

Likewise a series of three beautifully drawn large symbols appears at the end of the text in the manuscript of the Vinayavastvāgama on the last folio 523r (GBM 1050). ${ }^{392}$ This manuscript is purported to originate from Gilgit, dated from approximately the same period (i.e. ca. second half of the $8^{\text {th }}$ c.) ) $^{393}$ as the aforementioned manuscript of the Dïghāgama. The manuscript contains one of the popular and influential texts relating to the Mūlasarvāstivāda tradition of Buddhism.

Of the three symbols, the first symbol is almost on the left-hand margin, the second symbol in the centre and the third appears on the right margin of the folio. Similar to the symbols in the aforementioned manuscript, the symbols in this manuscript are not placed between series of double dandas or long vertical lines. The part of the last line (no. 6) on 523r on which the three symbols appear, can be read as follows: $v i_{\sqcup n} a_{\sqcup y} y a_{\sqcup} s a_{\sqcup} \dot{n g h} a_{\sqcup} b h e_{\sqcup} d a_{\sqcup} v a_{\sqcup} s t u_{\sqcup} s a_{\sqcup} m \bar{a} \sqcup p t a_{\sqcup} h \|$ ('[thus], the Vinayasanghabhedavastu is completed') and indicates the end of the text.

392 See Melzer 2014, 233.

393 For the date, Ibid., 234. 


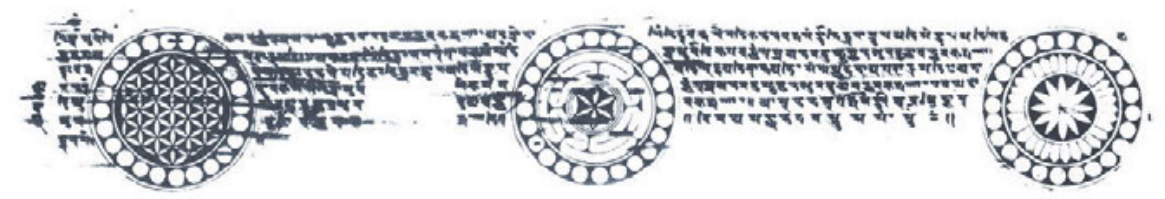

Fig. 3.6.2.4.2-III: A series of three large symbols at the end of the text in the manuscript of the Vinayavastvāgama, fol. 523 r (reproduced from Melzer 2014, 233, Fig. 3)

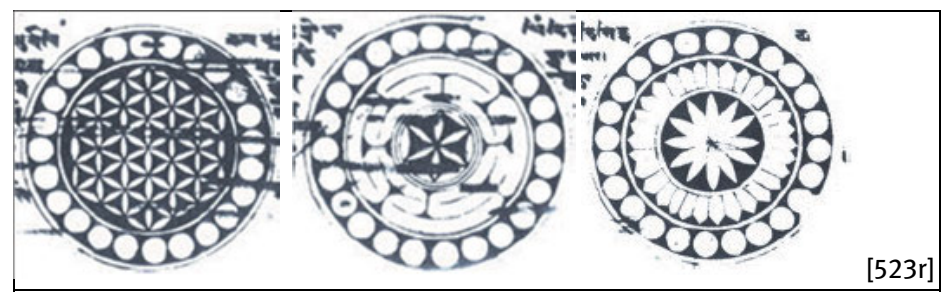

Fig. 3.6.2.4.2-IV: Enlarged symbols (reproduced from Melzer 2014, 233, Fig. 3)

A set of three large and beautifully drawn symbols also appears near the end of the text on 202r in the Nepalese manuscript of the Aștasāhasrikā Prajñāparamitā (CUL Add.866). ${ }^{394}$ This manuscript is dated NS 128 (1008 CE) and contains a Sūtra text belonging to the Mahāyāna Buddhism.

The folio has two string-holes and the text is divided into three textsections. Among the three symbols, the first and third symbols appear almost at the centre of the first and third text-sections. However, the second symbol appears immediately after the left string-hole, at the left side of the second textsection. All three symbols have been placed between seven sets of double dandas vertically arranged on the folio, with the exception of six sets of double dandas after the last symbol. In this instance, the first dandas have been lost due to the damaged condition of the leaf. Part of the second line on 202r contains the $32^{\text {nd }}$ chapter colophon and is followed by the colophon indicating the end of the text (line no. 3). ${ }^{395}$

394 See Bendall 1883, 1-4 and plate I. 3.

395 The sub-colophon and colophon read on 202r2-3 āryāștasāhasrikāyāṃ prajñāpāramitā||ఠ|yām parīndanāparivartto(!) nāma dvātrinśatimaḥ || 39 || [3] samāptā ceyam bhagavaty āryāșțasahasrikā(!)

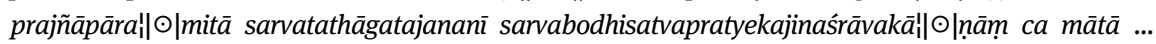
('[thus], the $32^{\text {nd }}$ chapter, namely, the parīndanā in the noble Perfection of Wisdom in Eight Thou- 


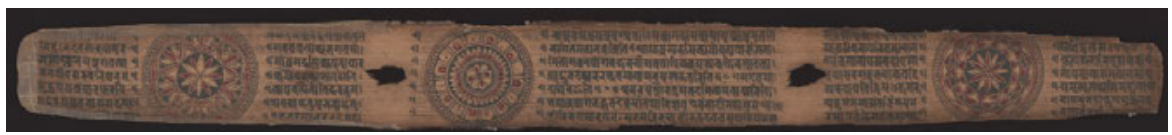

Fig. 3.6.2.4.2-V: A series of three large symbols at the end of the text of the Aștasāhasrikā Prajñāparamitā, fol. 202r @ CUL

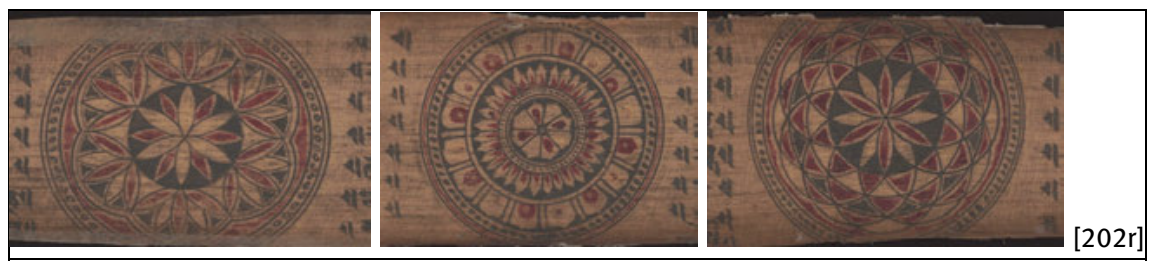

Fig. 3.6.2.4.2-VI: Enlarged symbols

When returning to examine the SDhPS, a near similar style of distribution of the symbols presents itself. It also contains one of the influential Sūtra texts of the Mahāyāna tradition.

Simple circles feature at the end of chapters in the manuscript, ${ }^{396}$ one 'figureeight knot' symbol, ${ }^{397}$ florally stylised viśvavajras (see section 3.6.2.1.5), ${ }^{398}$ 'tha' symbols ${ }^{399}$ and blank spaces. ${ }^{400}$ All these symbols are a height of one to three lines of the folio. However, a set of three symbols can be found on $138 \mathrm{v}$ (the penultimate folio of the manuscript), and on $139 \mathrm{r}$ and $139 \mathrm{v}$ (the last folio of the manuscript). ${ }^{401}$ All nine symbols are so large they are almost the entire height (top to bottom) of the folio. Two string-holes can be found on the folio and the text has been divided into three

sand Lines is concluded. 39. The Goddess, the Perfection of Wisdom in Eight Thousand Lines, the mother of all the Tathāgatas, all Bodhisattvas, each Jina and Śrāvaka is also concluded ...').

396 Namely on 100v5_ACC, 106v5_ACC, 116r1_BCC (type no. 2).

397 Namely on 43v5_ACC (type no. 3).

398 For instance, on 11r1_B/ACC, 20r1_B/ACC.

399 Namely on 46v6_ACC, 58v2_BCC, 62v4_B/ACC, 79r3_ACC, 84v2_ACC, 89v6_BCC, 93v2_ACC, 100v5_BCC, 113v5_ACC, 134v4_B/ACC (type no. 46).

400 Namely on 46v5_BCC, 58v3_ACC, 77r2_BCC, 84v2_BCC, 93v2_BCC, 98r3_B/ACC, 110r4_BCC, 116r1_ACC, 125v3-4_B/ACC, 130r4_B/ACC, 138r2_B/ACC.

401 In October 2018 I had the opportunity to see some part of this manuscript at the NAK including folios 138v, 139rv and received the digitised colour images of them and a few other folios. It seems folio 139 has deteriorated considerably since the manuscript was microfilmed. The upper and lower parts of the symbols on the folio (rv) are even more damaged. The folio has been repaired recently using supportive paper. 
text-section. All symbols near the end of the text appear at the centre part of each textsection and have been placed between a series of double parallel vertical ruling-lines. Please note that the second symbol on 139v contains a florally stylised viśvavajra at its centre (see section 3.6.2.1.5). Moreover, the left and right symbols on 139r look similar.

Part of the first line on $139 \mathrm{v}$ contains the $27^{\text {th }}$ chapter colophon. ${ }^{402}$ It is also the last chapter of the work in the manuscript. The chapter colophon is followed by a short statement and the verse 'ye dharma side of the folio 139rv has been damaged so a section of the text on the left has also been lost. In addition, folio $139 \mathrm{v}$ contains only one and almost a half of the text lines.

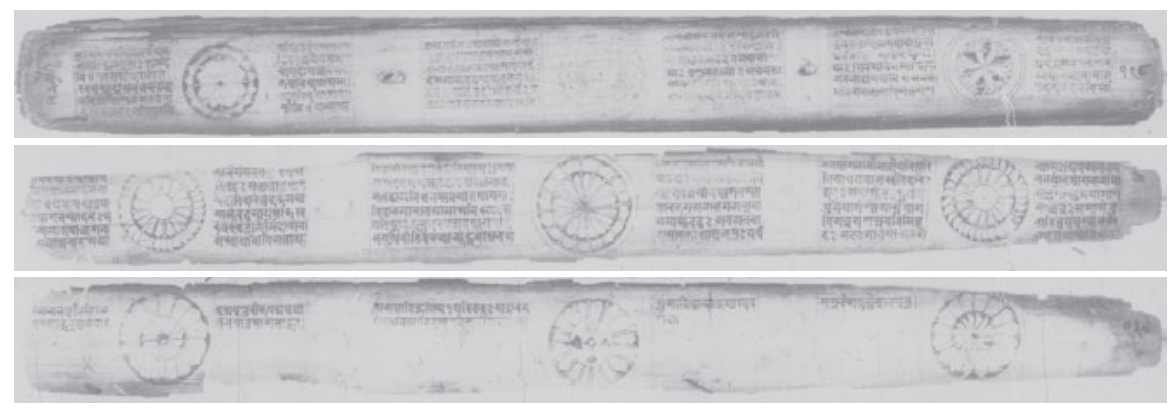

Fig. 3.6.2.4.2-VII: Three series of three large symbols at the end of the text in SDhPS, fols. $138 \mathrm{v}, 139 \mathrm{rv}$ ( ) NAK

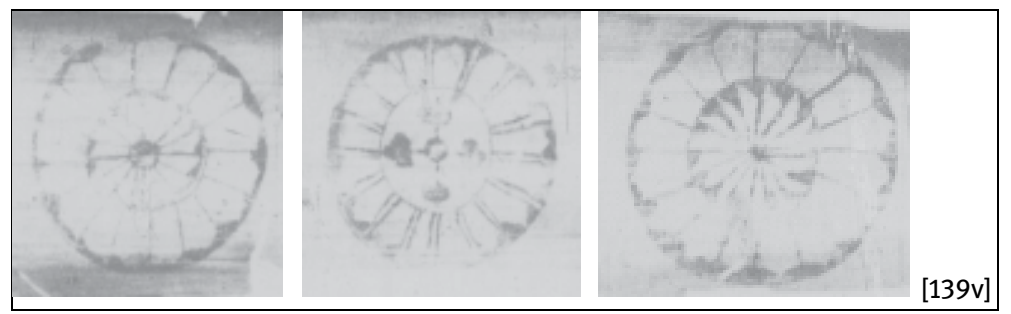

Fig. 3.6.2.4.2-VIII: Enlarged symbols

402 The chapter colophon reads saddharmapundarīke dharmaparyā $\|\odot\| y e$ saptāviñsatimah(!) parivartah ... ('[thus], the $27^{\text {th }}$ chapter called the dharmaparyayya in the Lotus of the True Law [is concluded]'). 
Almost the same pattern with three symbols appears at the end of the text in another Nepalese manuscript of the Saddharmapundarika on 132r (CUL Add.2197). The manuscript has been dated NS 185 (1065 CE). By contrast with the symbols found in other manuscripts ${ }^{403}$ described above and in manuscripts ${ }^{404}$ presented in this section below, symbols in Add.2197 are far smaller in size with only a height of four text lines. Aside from their size, the symbols have almost the same features as the other examples collected in this section. All three symbols appear almost at the centre of each text-section and are situated between three sets of vertical lines. They also appear at the near end of the $27^{\text {th }}$ chapter and are slightly larger than the other symbols found at the end of other chapters in the manuscript.

The other side of the folio (i.e. 132v) contains the $27^{\text {th }}$ chapter colophon and is followed by the manuscript production date, as well as other information such as the copying place, name of scribe etc. Before and after the chapter colophon, there are blank spaces and their height is one line of the folio. After the second blank space a siddham symbol appears followed by the date. ${ }^{405}$ It should be noted that the inner part (i.e. petals) of the first symbol looks somewhat similar to the inner element of the right symbol on 139v in SDhPS. The centre part of the centre symbol of the manuscript also exhibits some similarities to the middle part of the first symbol on $138 \mathrm{v}$ in SDhPS.

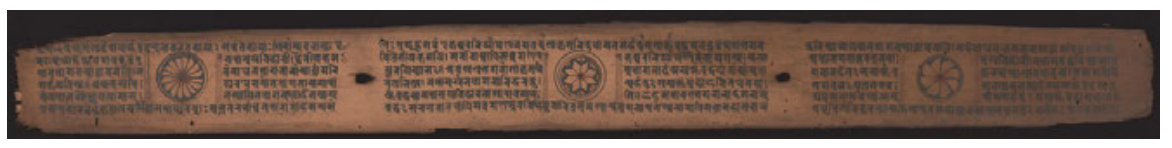

Fig. 3.6.2.4.2-IX: Symbols at the end of the text, fol. $132 \mathrm{r}($ ?) $)$ CUL

403 Such as in the manuscript of the Dïrghägama; in the manuscript of the Vinayavastvāgama; in the manuscript of the Aștasāhasrikā Prajñāparamitā (CUL Add.866), SDhPS).

404 For instance, in the Aștasāhasrikā Prajñāparamitā (NGMPP E 2122/7); in the manuscript of the Așțasāhasrikā Prajñāparamitā (KL 18 / NGMPP C 103/2).

405 The $27^{\text {th }}$ chapter colophon and dating line read on 132v1

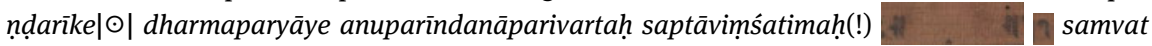
185 māghakrșnadivādaśa $|\odot|$ myā budhadine | ('[thus], the $27^{\text {th }}$ chapter called the anuparindana in the dharmaparyāya in the Lotus of the True Law [is concluded]. The [Nepāla] era 185 (1065 $\mathrm{CE}$ ), on Wednesday, the $12^{\text {th }}$ of dark fortnight of the month māgha'). 


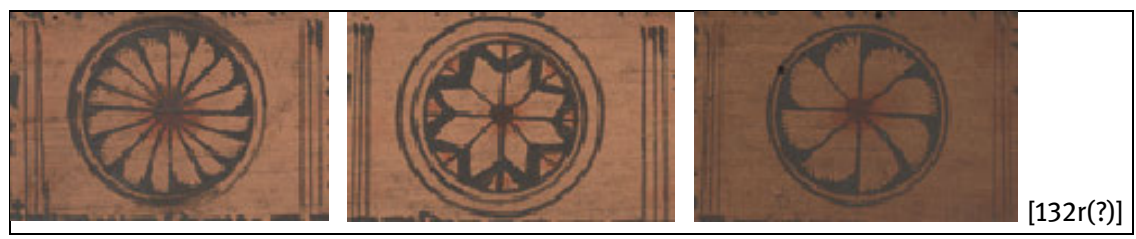

Fig. 3.6.2.4.2-X: Enlarged symbols

There is a series of three large symbols near the end of the text in the manuscript of the Aștasāhasrikā Prajñāparamitā (NGMPP E 2122/7) on 186?r. On palaeographical grounds the manuscript can probably be dated $11^{\text {th }} \mathrm{c}$. As seen below, the margins of the folio are damaged, therefore, a part of the first symbol and a small part at the bottom of the second and third symbol has been lost. The symbols have placed between sets of vertical lines and their height is almost that of the entire height of the folio.

Part of the chapter colophon can be found in line nos. 4-5 on the folio, but part of it has been lost due to damage on the left and right margins. Here we can assume that it is most probably the $32^{\text {nd }}$ chapter colophon, because after the stylised puspiki $\bar{a}$, the number ' 39 ' is also present after the $32^{\text {nd }}$ chapter colophon in the manuscript containing the same text (e.g., in the manuscript of the Aștasāhasrikā Prajñāparamitā (CUL Add.866) on 201r2). Before and after the chapter colophon there are stylised puṣpikās (lines nos. 4 and 5). A final statement indicating the end of the text appears after the chapter colophon and the verse number. ${ }^{406}$

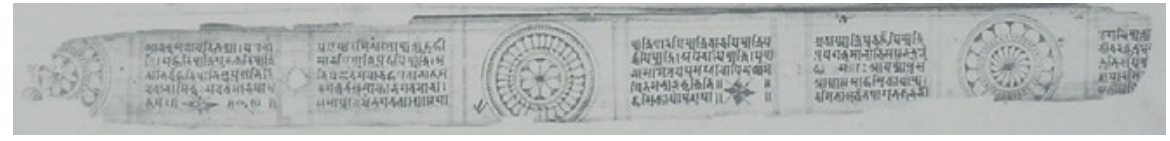

Fig. 3.6.2.4.2-XI: Symbols at the end of the text, fol. 186?r ( $)$ NAK

\footnotetext{
406 The part of the chapter colophon and the colophon on 186?r4-5 read $\|\odot\| \bar{a} r y \bar{a}$ ștasāhasrikāyām praljūāpārami///[5]///ttamah

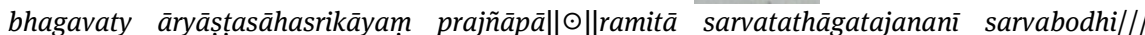
("[thus], [the $32^{\text {nd }}$ chapter] in the noble Perfection of Wisdom in Eight Thousand Lines [is concluded]. 39. The Goddess, the Perfection of Wisdom in Eight Thousand Lines, the mother of all the Tathāgatas, all Bodhi[sattvas]').
} 


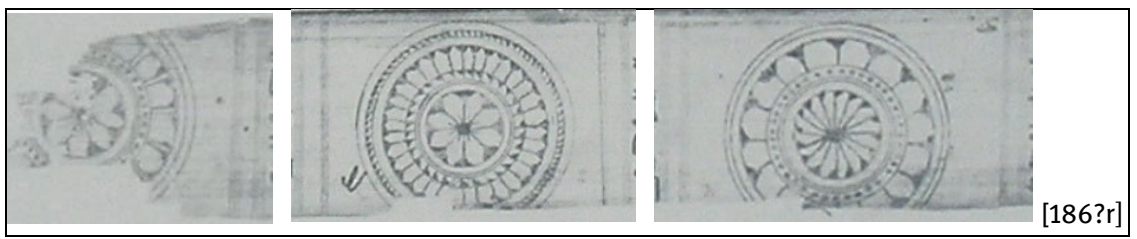

Fig. 3.6.2.4.2-XII: Enlarged symbols

Near the end of the text in another manuscript of the Aștasāhasrikā Prajñāparamitā (ca. 12 ${ }^{\text {th }}$ c.) (KL 18 / NGMPP C 103/2) a similar type of distribution of symbols occurs on 196v. As is evident, the folio is already in a fragmentary condition and, significantly, most of the left side of the folio is broken. On the left side there may have been a similar type of symbol to that in the second and third text-sections. The remaining two symbols have been placed between vertical lines and their height is almost the entire whole height of the folio. On $196 \mathrm{r} 6$ we can read āryāsțasāha/// which is most probably the preserved part of the $32^{\text {nd }}$ chapter colophon of which the most part is now lost, and on 196v there are the symbols and part of the colophon in the first line. ${ }^{407}$ Here we can assume that the beginning part of the colophon (i.e. samāptā ceyam bhagavaty āryāsțasāhasrikāyaṃ) found after the $32^{\text {nd }}$ chapter colophon on $201 \mathrm{r} 3$ in the manuscript of the Aștasāhasrikā Prajñāparamitā (CUL Add.866) and also after the $32^{\text {nd }}$ chapter colophon in the manuscript of the Aștasāhasrikā Prajñāparamitā (NGMPP E 2122/7) on 186?r4-5 (that has just been seen above) has been lost.

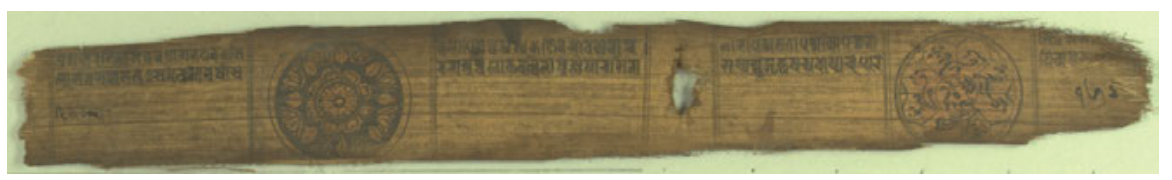

Fig. 3.6.2.4.2-XIII: Symbols at the end of the text, fol. 196v (C) KL

407 It reads prajñāpāramitā sarvatathāgatajanan̄ bodhisatvapratyekajinaśrāvakānā̃n(!) ca $m a \bar{t} \bar{a}$... ('[the Goddess], the Perfection of Wisdom [in Eight Thousand Lines], the mother of all the Tathāgatas, all Bodhisattvas, each Jina and Śrāvaka [is also concluded ...]'). 


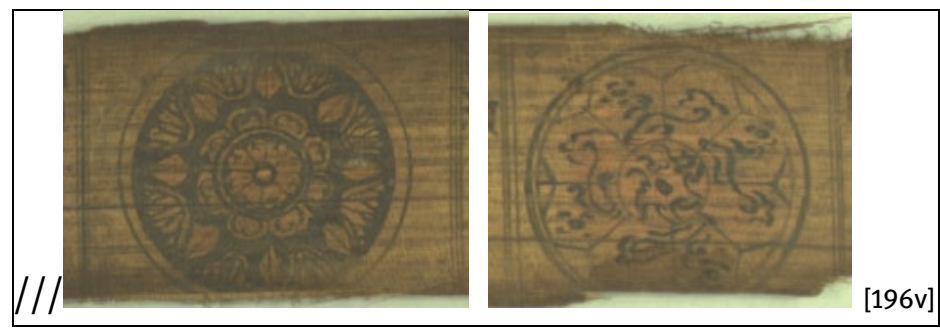

Fig. 3.6.2.4.2-XIV: Enlarged symbols

To verify the occurrence of such symbols at the end or near end of the text in the manuscripts seen above, attention is turned to the blank spaces present in some Buddhist manuscripts. Attestations of a series of three large blank spaces at the nearly end of the text appear in a few other manuscripts. Bearing this in mind, we can assume the blank spaces were supposed to be filled with sets of three large symbols or similar items seen in the manuscripts mentioned above. ${ }^{408}$ In the following, three manuscripts are presented featuring large blank spaces at the end.

In the manuscript of the Bodhisattvabhūmi (CUL Add.1702) ${ }^{409}$ a series of three large blank spaces can be found at the nearly end of the text on $144 \mathrm{v}$. The first blank space is on the left, the second almost in the middle section and the third appears at the right section of the folio. The folio contains five lines and the part of the fifth line of the text is the ending line. ${ }^{410}$ It is possible the three blank spaces here were to feature three large symbols as seen in the manuscripts above.

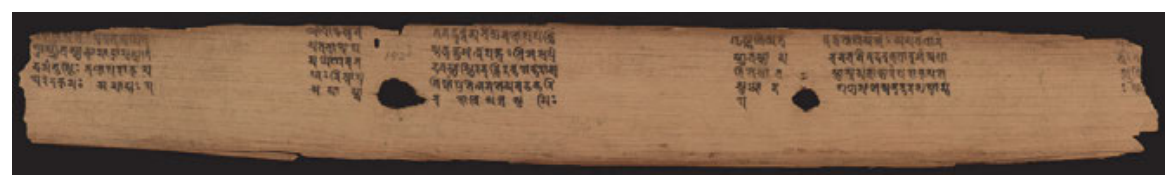

Fig. 3.6.2.4.2-XV: Large blank spaces at the end of the text, fol. $144 \mathrm{v}$ @ CUL

408 For instance, in the manuscript of the Dirghägama; in the manuscript of the Vinayavastvāgama; in the manuscript of the Așțasāhasrikā Prajñāparamitā (CUL Add.866); SDhPS; in the manuscript of the Saddharmapundarika (CUL Add.2197); in the manuscript of the Aștasāhasrikā Prajñāparamitā (NGMPP E 2122/7); in the manuscript of the Aștasāhasrikā Prajñāparamitā (KL 18 / NGMPP C 103/2).

409 The manuscript is undated. Bendall 1883, XXXIX and 191-196 dates the manuscript from the $9^{\text {th }}$ c., whereas Harimoto $2017,355-376$ recently suggested it could possibly be mid- ${ }^{\text {th }} \mathrm{c}$.

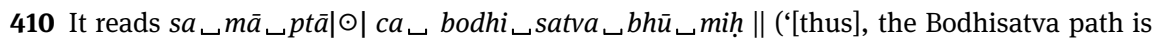
concluded') (the second blank space appears between mih and the double daṇda). 
Furthermore, an attestation of three large blank spaces can also be observed in the manuscript of the Sarvakulatattvasiddhividhivistaratantra (KL 143 / NGMPP C 14/20). ${ }^{411}$ Some part of the text can be seen at the top of the folio. It is likely it was to have been the first line of the folio but most of the line is now lost. ${ }^{412}$ Additionally, the remaining parts of the two stylised puṣpikās ${ }^{413}$ and double dandas in the first line are visible (see note below). The second line ends with a reading ${ }^{414}$ before the uppermost double dandas of the first blank space (left). An invocation $^{415}$ is on the bottom left part of the folio under the first blank space, preceded by a siddham. Compared with the handwriting of the text on other folios, both seem to have been written by another hand. Aside from them, sets of double dandas can be found on the left, middle and right part of the folio. It is possible the blank spaces between the sets of double dandas were to be filled with similar types of large symbols as evidenced by the manuscripts in the above section.

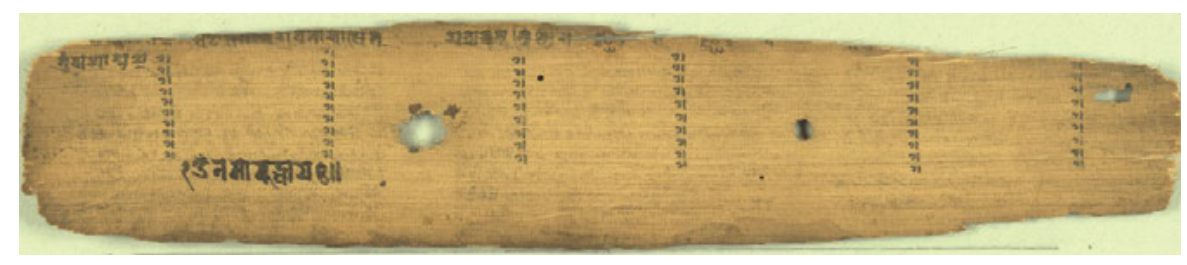

Fig. 3.6.2.4.2-XVI: Large blank spaces at the end of the text, fol.? ๑ KL

In the manuscript of the Așțasāhasrikā Prajñāpāramitā (NAK 5/76 / NGMPP A 37/11-A 38/1) a series of three large blank spaces can be found on 195v. They appear in the part of the colophon and post colophon. Each appears almost at the centre of the text-section. The $32^{\text {nd }}$ chapter colophon, the verse number and part of the colophon is on $195 \mathrm{r} 6$ and the remaining part of the colophon on

411 This manuscript is not dated. However, on paleographical grounds it may be dated ca. $9^{\text {th }} \mathrm{c}$. It should be noted that this manuscript shares a degree of similarities with the manuscript of the Bodhisattvabhümi (CUL Add.1702) for the size of its writing support, layout and a bit of its palaeography.

412 The preserved part of the line reads $c a+++[$ bha]gavato bhașitam $\backsim m$ abhyanandann iti

413 Parts of these symbols look like type no. 12 (see above).

414 The remaining part reads [... tan] tram samāptam' ('[... tan]tra is concluded').

415 It reads oṃ namo buddhāyaḥ(!) || ('oṃ, homage to Buddha'). 
195v1. ${ }^{416}$ A small part of the colophon 'mitā sarvatathāgatajanani sarvabo' that was written exactly in the upper part of the left blank space (see Fig. 3.6.2.4.2XVIII) and 'kāna' on the left side of the upper part of the middle blank space on $195 \mathrm{v}$, seem to have been deleted intentionally to keep the upper part fully open as there are no text lines at the top and bottom of the right blank space. The part of the colophon 'mitā sarvatathāgatajanani sarvabo' and 'kāṇa' which were originally written in the upper part of the first and second blank spaces, were probably deleted to keep the blank space open and the same parts were then written again after the blank spaces.

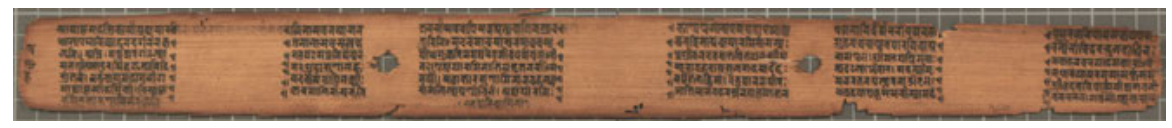

Fig. 3.6.2.4.2-XVII: Large blank spaces at the end of the text in the manuscript of the Aștasāhasrikā Prajñāpāramitā, fol. 195v @ NAK

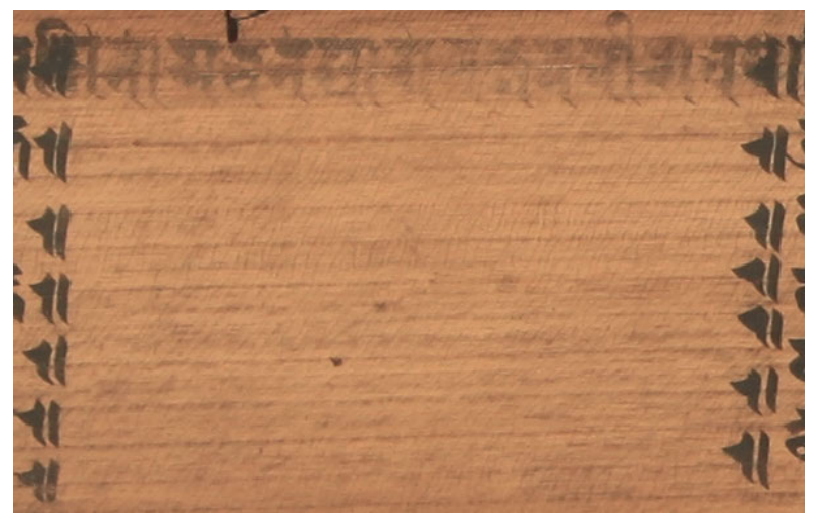

Fig. 3.6.2.4.2-XVIII: Enlarged left blank space in which some part of the first line of the text is erased to keep the space free

416 It reads āryāștasāhasrikāyāṃ|ఠ| prajñāpāramitāyām parīnda+parivartto nāma dvātriñśattamaḥ || 39 || samāptā ceyam bhaga+ [195v1]ty āryāșțasahasrikāyā (!) prajñāpāra V||/ «mitā sarvatathāgatajanan̄ sarvabo»> |||/ mitā sarvatathāgata $|\odot| j a n a \bar{i}$ sarvabodhisatvapratyekajinaśrāva $a<k a \bar{n} n a>>|| \mid / k \bar{a} n \bar{a} \bar{n}$ ca mātā ... ("[thus], the $32^{\text {nd }}$ chapter, namely, the parīnda[na] in the noble Perfection of Wisdom in Eight Thousand Lines is concluded. 39. [The Goddess], the Perfection of Wisdom in Eight Thousand Lines, the mother of all the Tathāgatas, all Bodhisattvas, each Jina and Śrāvaka is also concluded ...'). 
It is important to stress here that all seven manuscripts featuring such large symbols at the end or near end of the texts, such as the manuscript of the Dīrghāgama, Vinayavastvāgama (GBM 1050), Aștasāhāsrikā Prajñāparamitā (CUL Add.866), SDhPS, Saddharmapuṇdarīka (CUL Add.2197), Așțasāhasrikā Prajñāparamitā (NGMPP E 2122/7) and Așțasāhasrikā Prajñāparamitā (KL 18 / NGMPP C 103/2) contain Buddhist texts.

Similarly, the three manuscripts, that of the Bodhisattvabhümi (CUL Add.1702), Sarvakulatattvasiddhividhivistaratantra (KL 143 / NGMPP C 14/20) and Aștasāhasrikā Prajñāpāramitā (NAK 5/76 / NGMPP A 37/11-A 38/1) that feature a series of three large blank spaces at the end or near end of the text, also contain Buddhist texts. One of the manuscripts even contains the same text (i.e. Aștasāhasrikā Prajñāpāramitā) as three manuscripts; the Aștasāhasrikā Prajñāparamitā (CUL Add.866), Așțasāhasrikā Prajñāparamitā (NGMPP E 2122/7) and Aștasāhasrikā Prajñāparamitā (KL 18 / NGMPP C 103/2) which feature a series of large symbols at the end. It is likely the blank spaces in the three manuscripts were left free for the similar series of three large symbols contained in the other manuscripts described in the section above.

The occurrence and distribution of such large symbols at the end of the texts in the manuscripts from Gilgit and Nepal display a significant relation regarding their development and use in the two areas. There is only one visible difference apparent between the symbols in both manuscripts which lies in the symbols in the Gilgit manuscripts (such as the manuscripts of the Dirghägama and Vinayavastvāgama (GBM 1050)) not being placed between sets of double dandas or long vertical lines. The symbols in the Nepalese manuscripts e.g., the manuscript of the Aștasāhāsrikā Prajñāparamitā (CUL Add.866), SDhPS, Saddharmapuṇụīika (CUL Add.2197), Așțasāhasrikā Prajñāparamitā (NGMPP E 2122/7) and Aștasāhasrikā Prajñāparamitā (KL 18 / NGMPP C 103/2) appear either between sets of double daṇas or long vertical lines. This latter phenomenon can be seen in the case of the large blank spaces at the end or near end of the texts in the Nepal manuscripts such as the manuscript of the Bodhisattvabhūmi (CUL Add.1702), Sarvakulatattvasiddhividhivistaratantra (KL 143 / NGMPP C 14/20) and Aștasāhasrikā Prajñāpāramitā (NAK 5/76 / NGMPP A 37/11-A 38/1).

Thus far, I have not seen a similar pattern of symbols in manuscripts containing other texts, whether medical, poetic, puranic, or otherwise. Thus, it may be assumed that this phenomenon may have been a feature both proper and in keeping with Buddhist manuscript tradition. 


\subsection{Symbols occurring together with foliation numbers}

In some manuscripts of my corpus, small and stylised simple puṣpikās occur together with foliation numbers. These can be understood as decorations and as some sort of structural element in the manuscript where they appear at regular intervals. Regarding the latter, it is difficult to say whether or not this kind of information was of any help to the actual user of the manuscript.

In manuscripts from West India, a small stylised puspikā occurs every ten folio numbers (e.g. folio number $10,20,30$, etc.). ${ }^{417}$ Such symbols appear frequently under the letter-numerals ${ }^{418}$ on the left-hand margin of the folio. These symbols are presented below with the foliation number accompanying them, and the (figure-numerical) foliation, without symbol, on the right-hand margin of the same folio.

\section{TSa}

TSa is made up of 187 folios. The letter-numerical foliation can be found on the left-hand margin and figure-numerical foliation on the right-hand margin on the verso. With every tenth foliation a small stylised pușpika appears on the lefthand margin. This is placed exactly under the letter-numeral. All symbols look identical (except for number 100, which appears with the additional upper elements such as the circle and two semi-circular petals on the left and right sides and number 130, which only features a circle): they contain a central circle or a dot surrounded by the three almost semi-circular petals on the left, right and lower sides. The use of additional elements for number 100 may be to emphasize the number '100'. All symbols with foliation can be seen in Fig. 3.7.1-I.

417 For the study of the foliation of Jaina manuscripts, see Kapadia 1973, 171-186. Small stylised puspikās can be found together with most of the tenth foliation in Plates V-VII.

418 For the label 'letter-numerals', see Bendall 1883, liii; Kapadia 1973, 171-186; Balbir et al. 2006, 61-62. 


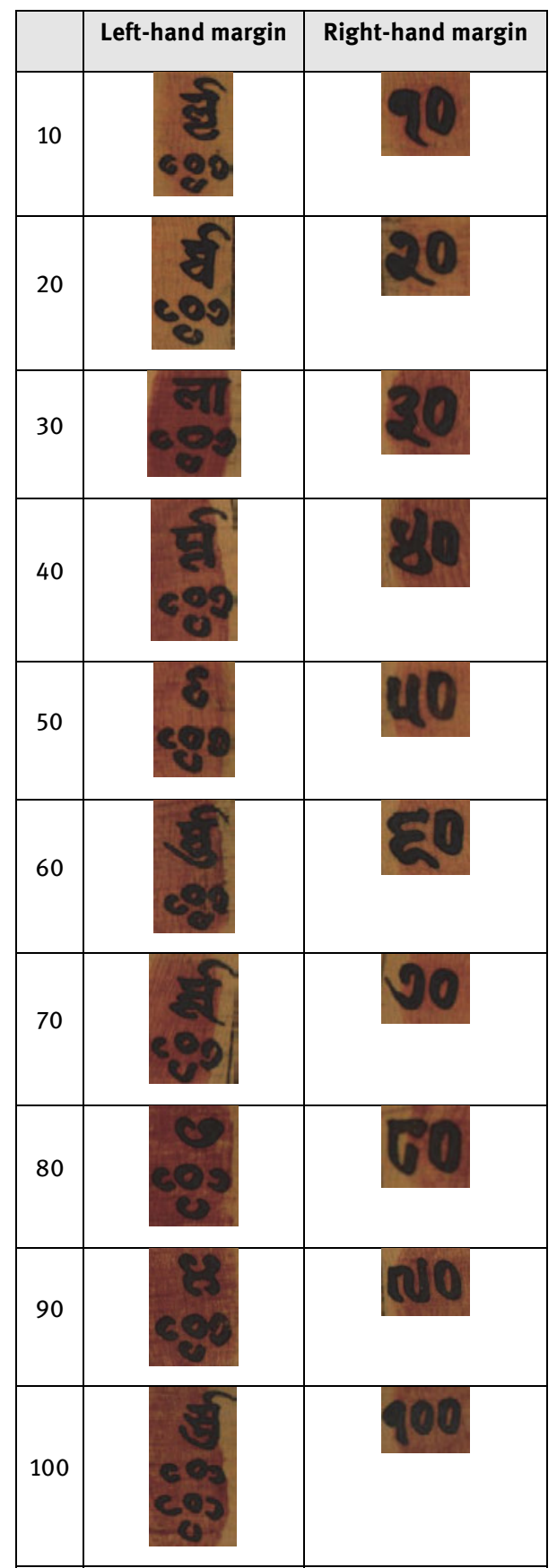




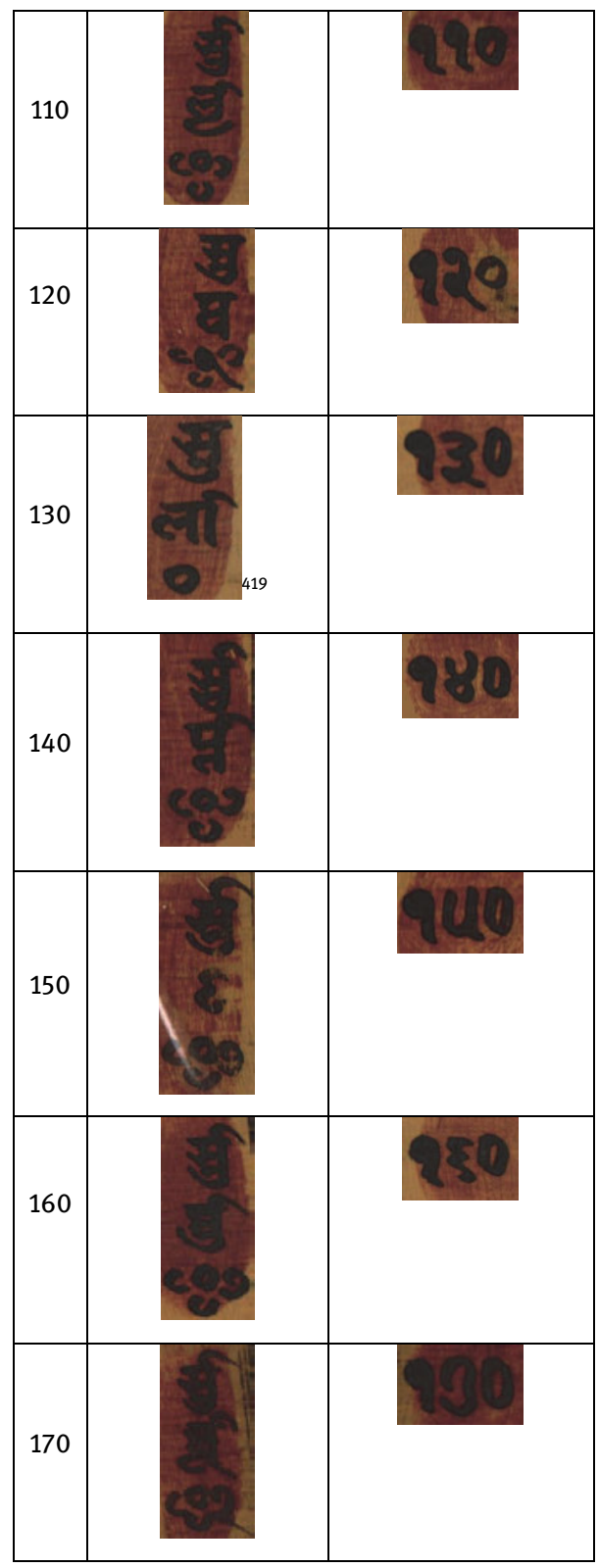

419 In this case there is just a circle. This may have been drawn for a centre part of the stylised puṣpikā or similar symbol. 


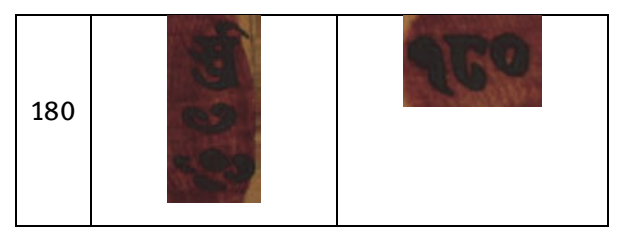

Fig. 3.7-I: Symbols with foliation numbers

\section{TSPV}

TSPV consists of 309 folios. Letter-numerical foliation can be found on the lefthand margin and figure-numerical foliation on the right-hand margin of the verso. In most of TSPV every tenth letter-numerical foliation is accompanied by a small stylised pușpikā (between 130-300, there are no symbols with foliation). There appears to have been more than one scribe involved in the manuscript's production; it may be that one of the scribes simply did not draw symbols with foliation, explaining why no symbols appear in some parts of the manuscript (see section 3.9.4 for more details below). Symbols appear exactly under the letter-numerals on the left-hand margin on the folio. Most of the symbols look almost identical (except for 100, 140 and 310). Each symbol contains one circle and on the top of the circle a line or a stroke has been added horizontally. The circle appears surrounded by three almost semi-circular petals on the left, right and bottom sides. However, regarding the symbol with the number 100, there is an additional circle almost similar to the centre part of other symbols with a horizontal line or a stroke at the top, and two semi-circular petals at its left and right sides. Similar to the symbol in the aforementioned manuscript, the use of the additional elements with the stylised puspiki $\bar{a}$ for the foliation number 100 is perhaps to emphasize the number ' 100 '. The foliation number 140 contains only a circle beneath it and the symbol with number 300 is slightly different and more attractive with its differing petals on the right and left sides. All symbols with foliation can be seen in Fig. 3.7.1-II. 


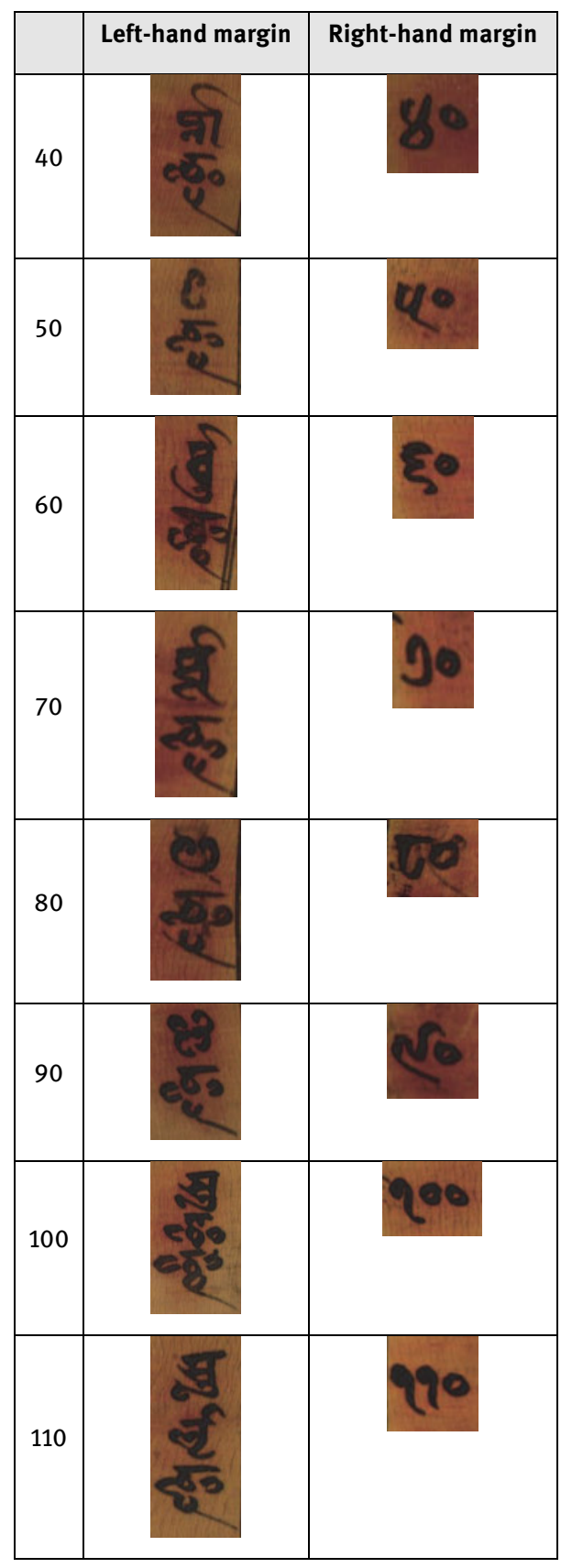




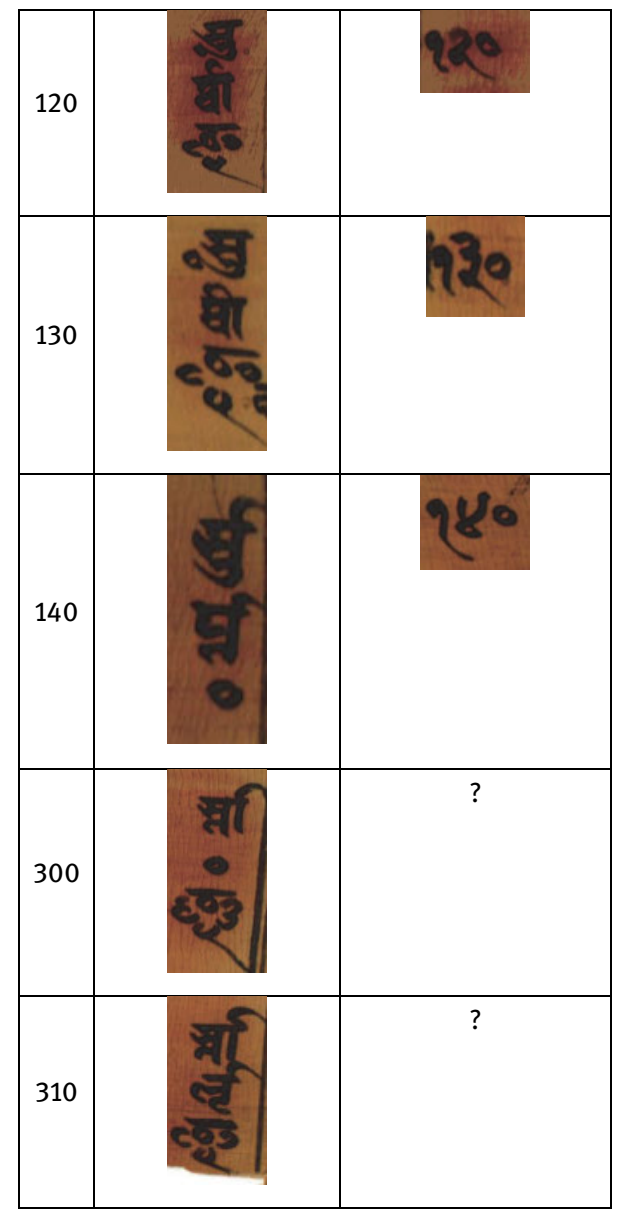

Fig. 3.7-II: Symbol with foliation

\section{HVM}

HVM consists of 107 folios. Letter-numerical foliation can be found on the lefthand margin and figure-numerical foliation on the right-hand margin on the verso. As in the aforementioned manuscripts, every tenth letter-numerical foliation in this manuscript also appears with a small stylised puspikā. The symbol is exactly under the letter-numerals on the left-hand margin of the folio. Most of the symbols are identical. The symbols on 10, 20, 30, 50, 70 and 90 look similar. The symbols contain one circle in the centre surrounded by three almost semicircular petals and two lines. Each of its petals faces the outside. The symbol 
with 40 also contains one circle at its centre and two lines and three near semicircular petals, however, each of its petals faces inside and one 'tail' has been added to each petal. The symbol with 60 consists of one circle at the centre surrounded by two almost semi-circular petals (on the left and right), two lines and one circle on the bottom. The symbol with 80 contains one circle at its centre surrounded by four lines and four near semi-circular petals. ${ }^{420}$ Like the abovementioned examples, each petal faces the outside. The symbol with 100 is made of one circle at the centre surrounded by two near semi-circular petals facing inside, one circle at the bottom and two lines. Both petals (left and right) and the circle contain a tail. All symbols with foliation can be seen in Fig. 3.7-III.

\begin{tabular}{|c|c|c|}
\hline & Left-hand margin & Right-hand margin \\
\hline 10 & & \\
\hline 20 & & \\
\hline 30 & & \\
\hline 40 & & \\
\hline 50 & & \\
\hline 60 & & \\
\hline & & \\
\hline
\end{tabular}

420 See section 3.4, type no. 10 above. 


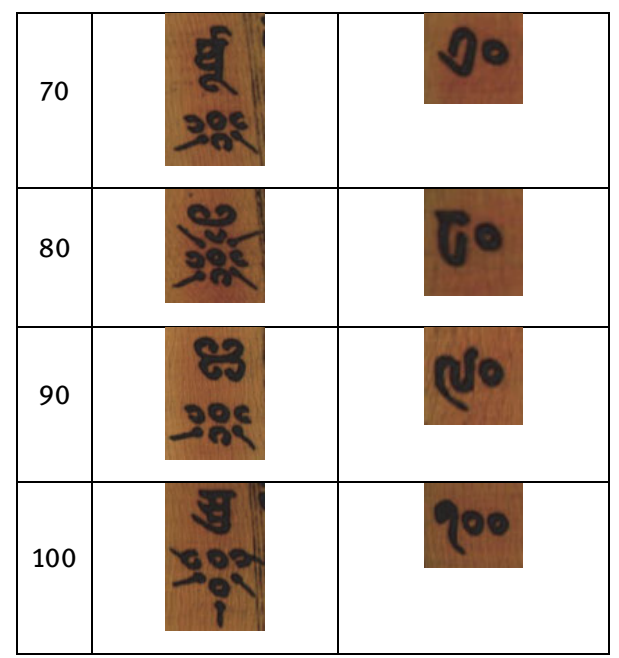

Fig. 3.7-III: Symbol with foliation

\section{BCV}

BCV consist of 78 folios. Similar to other manuscripts, letter-numerical foliation can be found on the left-hand margin and figure-numerical foliation on the right-hand margin on the verso. However, an exception is that only the tenth foliation in the manuscript is accompanied by small stylised puspika . A symbol can be found under the letter-numerical foliation on the left hand-margin on the folio. It contains one circle in the centre surrounded by four almost semicircular petals and four lines. ${ }^{421}$ The symbol with foliation can be seen in Fig. 3.7-IV.

421 Identical symbols with foliations can be found, see Kapadia 1936, Plate V, with foliation 30 , column 3, Plate VI, with foliation 50, column 3, with foliation 60 , column 3, with foliation 70 , column 2, with foliation 80 , column 2, with foliation 90 , column 3. See section 3.4, type no. 8 above. 


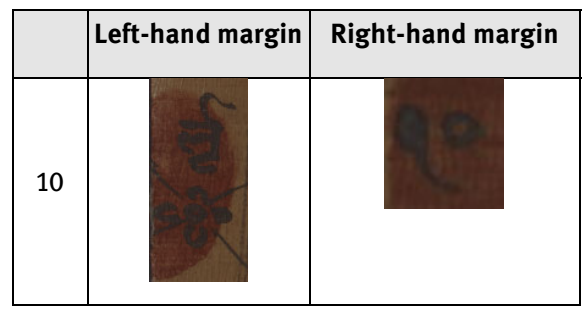

Fig. 3.7-IV: Symbol with foliation

\subsubsection{Preliminary conclusions}

Manuscripts HVM, TSa, TSPV and BCV, purported to originate from West India, contain symbols every ten folios in a remarkable number of cases. ${ }^{422}$ The symbols are small and simple in shape, but quite well drawn. To the best of my knowledge, such a feature is uncommon in manuscripts from the regions of Nepal and East India; thus it may be assumed it occurs only in West Indian manuscripts. These symbols are clearly decorative, but also structure the bundle, dividing it into welldefined units. Whether this was their intended function remains uncertain. They cannot be compared to the numbers (or symbols, etc.) used to order the quires of a codex manuscript as the ten folio units are not bound together.

422 Also in the manuscript of the Tilakamañjari (VS 1130 / 1073 CE) (Jinabhadrasūri Grantha Bhanḍāra, Jaisalmer, no. 402) with foliation 110, 150; in the manuscript of the Udbhațakāvyālañkāralaghuvṛtti (VS 1160 / 1103 CE) (Jinabhadrasūri Grantha Bhaṇ̣āra, Jaisalmer, no. 329) with foliation 10; in the manuscript of the Upadeśapadaprakaranalaghuțika (VS 1193 / 1136 CE) (Jinabhadrasūri Grantha Bhaṇ̣āra, Jaisalmer, no. 215) with foliation 170, 190, 200, 210, 290; in the manuscript of the Savaga Padikkamana Sutta cunni (Śrāvakapratikramasūtra-cūrṇi) (VS 1317 / 1260 CE) (Museum of Fine Arts, Boston. Denman Waldo Ross Collection, 30.1.1-229) with foliation 10, 30, 40, 50, 60, 70, 80, 90, 100, 120, 130, 150 (only with circle), 160 (only with circle), 170 (only with circle), 180, 200 (with two circles), 220, 240(?), 250, 270. The lower element that appears with foliation 110 is hard to identify as some part of it is faded. The folios 20, 190, 230, 260, 280 seem to be missing; also in the manuscript of the Sthānāngasūtravrtti (VS 1300 / 1295 CE) (Jinabhadrasūri Grantha Bhaṇdāra, Jaisalmer, no. 6) with foliation 10, 20, 30, 40, 50, 60, 70, 80, 90, 160, 170, 180, 240, 250, 280, 310, 330 (partly lost), 340. Furthermore, many of the tenth foliations that are presented by Kapadia 1936 they also appear with stylised small puṣpikās, for instance, Plate I, with foliations 10, 20, 30, 40, Plate II, foliation with 50, 60, 70, 80, 90, 100, 110, 200, 260, 290, 300, 400, Plate V, foliation with 10, 20, 30, 40, Plate VI, foliation with 50, 60, 70, 80, 90, Plate VII, foliation with 100, 200, 300,400 . These attestations of symbols mainly with the tenth foliation in West Indian manuscripts suggest a distinct practice. 


\subsection{Symbols and other features as a means to connect separated parts of the manuscript}

Palm-leaf manuscripts are bundles of leaves held mainly together by a piece of string (sūtra or nādì) threaded through pre-bored holes. The front and back folios of the bundle are usually protected by wooden covers (pața or pațalī).423

As the strings are loosened or strings and wooden covers removed when the manuscript texts are read, it may easily occur - intentionally or not - that unrelated or stray folios find their way in the bundle when it is restrung, or folios are not placed back in their original position and have been left out of the bundle to which they belong. Regarding the latter, different parts of the manuscript can end up in libraries and archives quite distant from one another. Alongside palaeographical and layout-related features, symbols assist in reconstructing manuscripts by reconnecting the dismembered parts. Here I will present two relevant examples.

\subsubsection{An observation: Symbols and other features on folio in $\mathrm{SP}_{1}$ and one of the folios in A 38/5}

In the NAK, one of the bundles of MS 3/737 contains many folios from different manuscripts. This information has been reiterated by other scholars ${ }^{424}$ and by the relevant entry in the NGMCP online catalogue. ${ }^{425}$ The manuscript was photographed by the NGMPP on reel no. A 38/5 and later retaken under various nos., namely A 39/19, A 934/20, A, 1166/5, A 1169/3 and A 1170 (henceforth, I call it A 38/5). Among the scholars who delved into the fragmentary folios of this manuscript, I would like to mention the recent study of Harimoto (2011, 93, note 7), who informs us that the bundle contains one folio belonging to $\mathrm{SP}_{1}$.

$\mathrm{SP}_{1}$ is also kept in the same archive in Kathmandu as MS no. 2/229 and has been photographed by the NGMPP on reel no. B 11/4. The manuscript is damaged in many places and the foliation is almost completely lost. It has been used by Bhațarāī (1988) with siglum ' $k h a$ ' and by Adriaensen et al. (1998) with siglum 'SP,' for their editions. In this study I too call it $\mathrm{SP}_{1}$ and compare the features of the folio

423 For instance, see Bühler 1896, 93; Losty 1982, 7.

424 Such as, Matsuda 1996; Harimoto 2011.

425 See NGMCP entry at: <http://ngmcp.fdm.uni-hamburg.de/mediawiki/index.php/A_385_Saddharmapu\%E1\%B9\%87\%E1\%B8\%8Dar\%C4\%ABka(s\%C5\%ABtra)> (last accessed on 10.10.2018). 
from bundle of A 38/5 and features from folios of $\mathrm{SP}_{1}$. I also discuss the features of $\mathrm{SP}_{1}$ in sections 3.9.1 and 4.2.2.1 below.

All symbols in $\mathrm{SP}_{1}$ are only the height of one text line (see Appendix below). Similarly, the symbol on the folio from A 38/5 also has the same height on the folio. The shape of the symbols is similar to some extent (see Fig. 3.8.1-I below). Furthermore, the double dandas demarcating the symbols (and that are also placed after ślokas) are similar in both cases: a hook-like line has been added horizontally on the left side of the first of the two dandas ${ }^{426}$ (see Fig. 3.8.1-I and section 3.9.1 below).

\begin{tabular}{|l|l|}
\hline Symbol in SP1 & Symbol on one of the folios which is in A 38/5 \\
\hline 11 [221a4_ACC_9th] & [?3_ACC_9 $\left.{ }^{\text {th }}\right]$ \\
\hline
\end{tabular}

Fig. 3.8.1-I: Symbol on one of the folios in $\mathrm{SP}_{1}$ and on one folio in $\mathrm{A} 38 / 5$

Space-fillers provide further evidence as they are of almost identical shape. They have a hooked 'head' followed by a wavy 'tail' that becomes a straight line at the end (e.g., see Fig. 3.8.1-II).

\begin{tabular}{|c|c|}
\hline Selected space-filler on one folio in $\mathbf{S P}_{1}$ & Space-filler on one of the folios which is in A $38 / 5$ \\
\hline [220b_?rv5_9 $\left.9^{\text {th }}\right]$ & {$\left[? \mathrm{rv5} 9^{\text {th }}\right]$} \\
\hline
\end{tabular}

Fig. 3.8.1-II: Space-filler on one of the folios of $\mathrm{SP}_{1}$ and on one folio in $\mathrm{A} 38 / 5$

The overall layout is almost identical in both cases. There are two string-holes ${ }^{427}$ on each folio and the text is divided into three text-sections, each with five lines of text. Another similar feature is how the ślokas are divided in a similar style: most of the first and second halves of each śloka has been divided by means of small gaps in

426 See Bühler 1896, 84: 'Vom Ende des 8. Jahrh. bis zum 13. Jahr. erhält der erste Strich auch einen Haken in der Mitte links ...' ('from the end of the $8^{\text {th }}$ c. until $13^{\text {th }} \mathrm{c}$. the first stroke contains a hook in the middle left') (the translation is mine).

427 One should not be confused here as string-hole with the damaged part at the near centre on the folio in A 38/5. 
each text-section (e.g., see Fig. 3.8.1-III and 3.8.1-IV). When the arrangement of lines of ślokas is done in this manner, each line of the folio usually contains three ślokas.

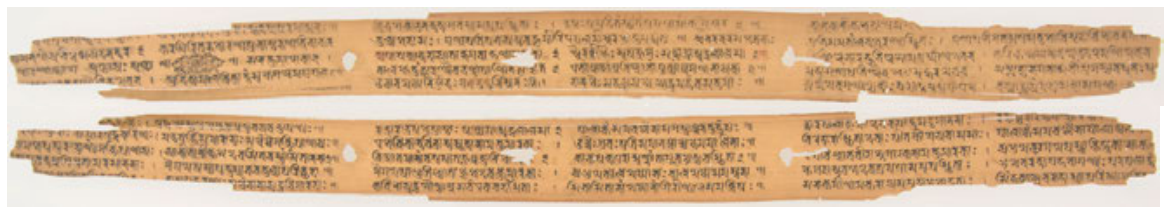

Fig. 3.8.1-III: Overall layout, the folio which is now in the bundle of $A 38 / 5$ C NAK

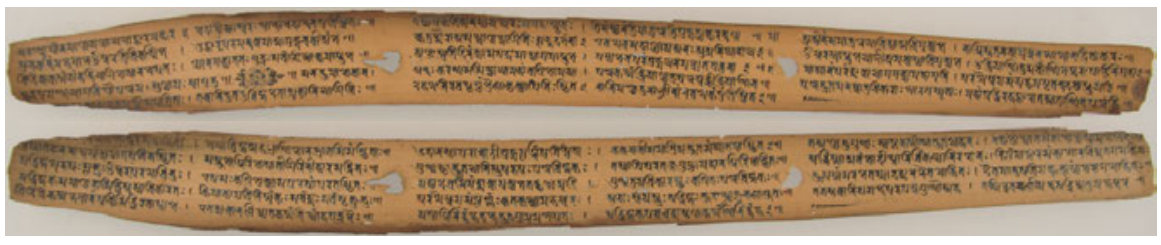

Fig. 3.8.1-IV: Overall layout, one of the folios $(220 \mathrm{~b} / 221 \mathrm{a})$ of $\mathrm{SP}_{1} \odot \mathrm{NAK}$

Based on the blatant similarities of the shape of symbols, dandas, space-fillers and overall layout, the assumption can be made that the folio from A 38/5 belongs to $\mathrm{SP}_{1}$.

\subsubsection{An observation: Symbols and other features in $\mathrm{SP}_{3}$ and $\mathrm{SP}_{4}$}

In the Bodleian Library, Oxford, one manuscript of the Skandapurāna has been kept under MS Sansk a 14 (R). This manuscript has been designated by Adriaensen et al. (1998) with the siglum ' $\mathrm{SP}_{3}$ ' for their edition. I use the same siglum for this study.

There are 22 fragments of the Skandapurāna collected under manuscript 4/2260 in the NAK, that have been photographed by the NGMPP on reel B 12/2 (later retake as A 1084/7). This manuscript is designated by Bhațtarāī (1988) with the siglum ' $g a$ ' and by Adriaensen et al. (1998) with the siglum 'SP'. In the present work I also refer to this manuscript as $\mathrm{SP}_{4}$.

Adriaensen et al. have already pointed out the close connection between $\mathrm{SP}_{3}$ and $\mathrm{SP}_{4}$, which, according to them, once formed a single bundle, although they are now kept in different libraries. In addition to other factors, such as 
palaeographical evidence, layout, etc., ${ }^{428}$ the editors based their assumption on the fact that the symbols of both manuscripts are of near identical shape.

Hereafter, I will focus on the symbols appearing in both $\mathrm{SP}_{3}$ and $\mathrm{SP}_{4}$, and I will also examine the use of colour, although I only had the opportunity to see but a few colour images ${ }^{429}$ of $\mathrm{SP}_{3}$ for the preparation of this book.

The first set of similar symbols contains double circles surrounded by eight petals, in turn enclosed by double concentric circles (see Fig. 3.8.2-I). ${ }^{430}$ They can be found on $5 \mathrm{r} 1$ in $\mathrm{SP}_{4}$ and on $112 \mathrm{v} 2,127 \mathrm{r} 1,147 \mathrm{v} 4,165 \mathrm{v} 1$ in $\mathrm{SP}_{3}$. The symbols in both manuscripts occupy an area of three lines on the folio. The double dandas that enclose the symbols in both manuscripts are identical: the first danda of the two often have a sharp hooked element.

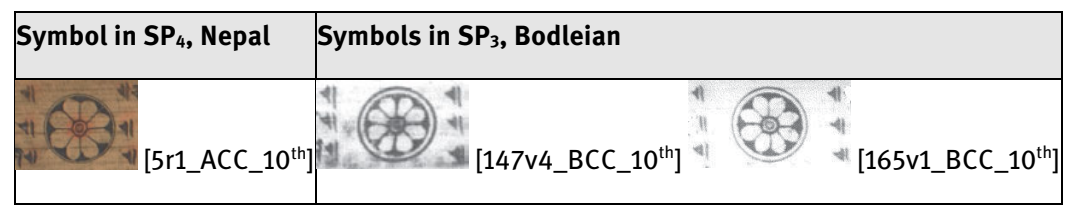

Fig. 3.8.2-I: Similar symbols in $\mathrm{SP}_{3}$ and $\mathrm{SP}_{4}$

The second set of identical symbols appears on $71 \mathrm{r} 2$ in $\mathrm{SP}_{4}$ and on 26r6, 69r4, 88r1, $136 \mathrm{r} 4$ in $\mathrm{SP}_{3}$ (e.g., see Fig. 3.8.2-II below). ${ }^{431}$ The height of all symbols is two lines of the folio and consists of one circle and eight petals. Double dandas enclosing symbols in both manuscripts are also identical.

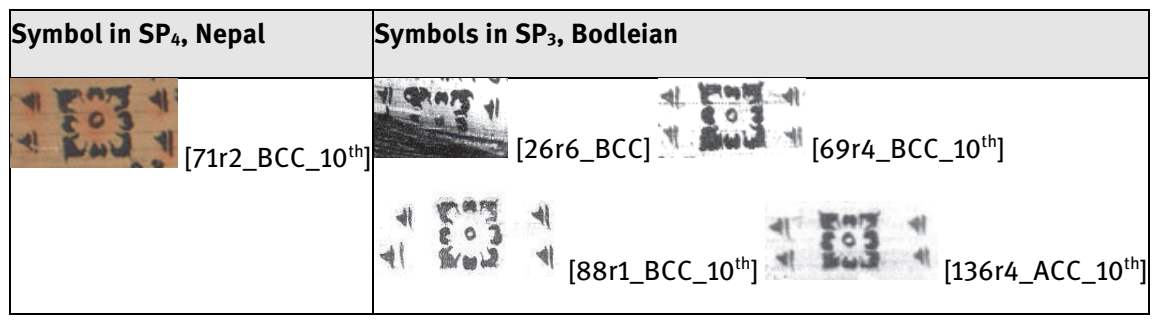

Fig. 3.8.2-II: Similar symbols in $\mathrm{SP}_{3}$ and $\mathrm{SP}_{4}$

428 See Adriaensen et al. 1998, 34.

429 Here I thank my friend Dr Camillo Formigatti (Oxford Library) who was so kind and checked some folios of this manuscript for me at the library during the preparation of the present book.

430 See section, 3.4, type no. 35 above.

431 See section 3.4, type no. 27 above. 
The third set of identical symbols is found on 71r2, 71v1 in $\mathrm{SP}_{4}$ and 3v5, 70r1, 139r4, $193 \mathrm{r} 5$ in $\mathrm{SP}_{3}$ (see Fig. 3.8.2-III). Some of the left part of the symbol on 3v5 in $\mathrm{SP}_{3}$ has been lost, however, its right part is still visible, and looks similar to the part of other symbols presented here. The symbols consist of circle surrounded by eight petals and their height is two lines of the folio. Here the double dandas that enclose the symbols are almost identical.

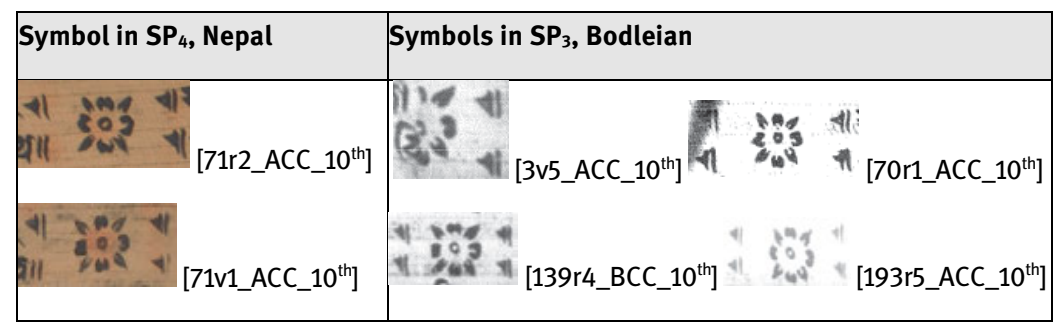

Fig. 3.8.2-III: Similar symbols in $\mathrm{SP}_{3}$ and $\mathrm{SP}_{4}$

The fourth type of 'near' similar symbols can be found on $68 \mathrm{v} 3$ in $\mathrm{SP}_{4}$ and on 21v1, 196v1 in $\mathrm{SP}_{3}$ (see Fig. 3.8.2-IV). The symbol has at its centre, double circles surrounded by eight petals. To some extent, the symbols have a 'rhombus'-like appearance. The height of the symbols in both manuscripts is that of two lines of the folio. The double dandas that demarcate the symbols in both manuscripts are identical.

\begin{tabular}{|c|c|}
\hline Symbol in $\mathrm{SP}_{4}$, Nepal & Symbol in $\mathrm{SP}_{3}$, Bodleian \\
\hline \#1 C & 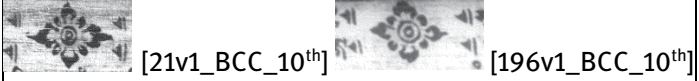 \\
\hline
\end{tabular}

Fig. 3.8.2-IV: Similar symbols in $\mathrm{SP}_{3}$ and $\mathrm{SP}_{4}$

Another set of identical symbols found in both manuscripts features a symbol containing one curved-like line at its centre (see Fig. 3.8.2-V). ${ }^{432}$ As already mentioned above in section 3.4 (Fig. 3.4-IV), this symbol has similarities with some of the letter-numerals ' 80 '. This symbol can be found on $71 \mathrm{v} 5$ in $\mathrm{SP}_{4}$ and many times (such as the right column in Fig. 3.8.2-V) in $\mathrm{SP}_{3}$ and its height is often just

432 See also section 3.4, type no. 4 above. 
one line of the folio. Furthermore, double dandas that enclose symbols in both manuscripts are also identical.

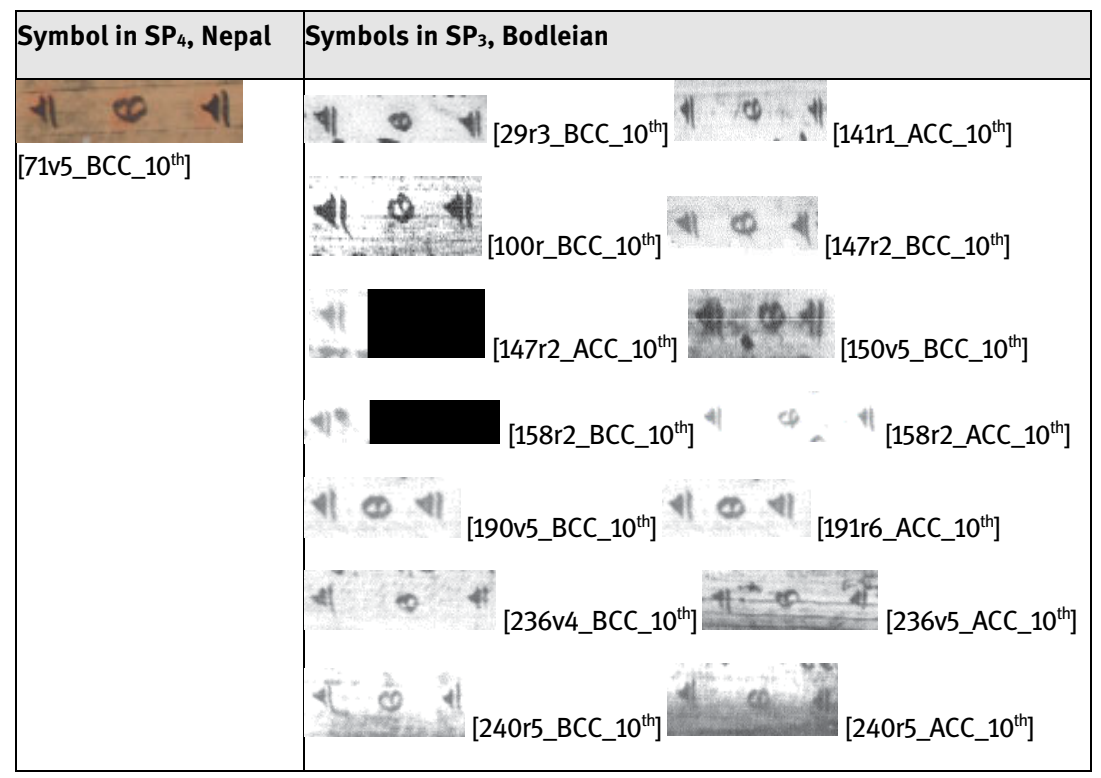

Fig. 3.8.2-V: Similar symbols in $\mathrm{SP}_{3}$ and $\mathrm{SP}_{4}$

The sixth set includes the symbol that looks like a 'figure-eight knot', or two small circles joined together horizontally (see Fig. 3.8.2-VI below). ${ }^{433}$ They appear on $247 \mathrm{v} 5$ in $\mathrm{SP}_{4}$ and on folios (such as right column in Fig. 3.8.2-VI) in $\mathrm{SP}_{3}$. In both manuscripts they are a height of one text-line of the folio. The double dandas that demarcate symbols in both manuscripts are identical.

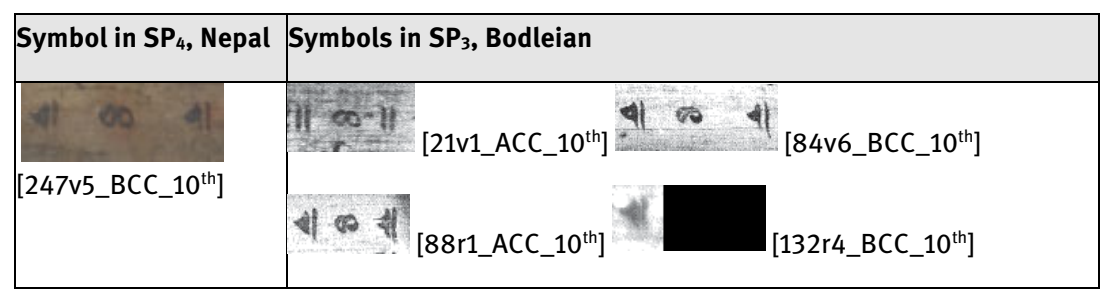

433 See section 3.4, type no. 3 above. 


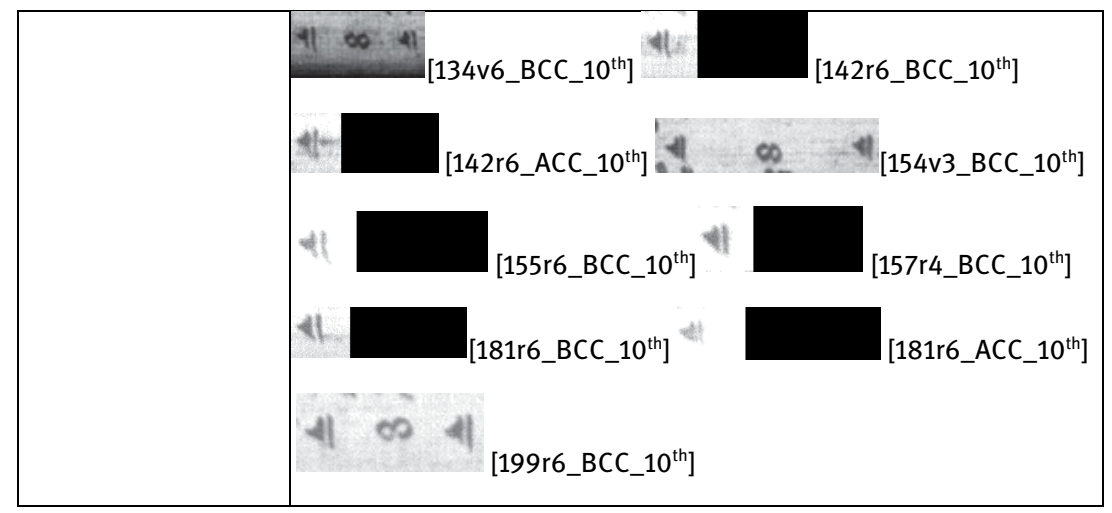

Fig. 3.8.2-VI: Similar symbols in $\mathrm{SP}_{3}$ and $\mathrm{SP}_{4}$

Another set of identical symbols includes a simple circle (see Fig. 3.8.2-VII). ${ }^{434}$ They are on $274 \mathrm{v} 5$ in $\mathrm{SP}_{4}$ and on folios (as seen in the right column in Fig. 3.8.2VII) in $\mathrm{SP}_{3}$ and occupy only one line on the folio. Similar to the examples above, the double dandas that enclose the symbols in both manuscripts are identical.

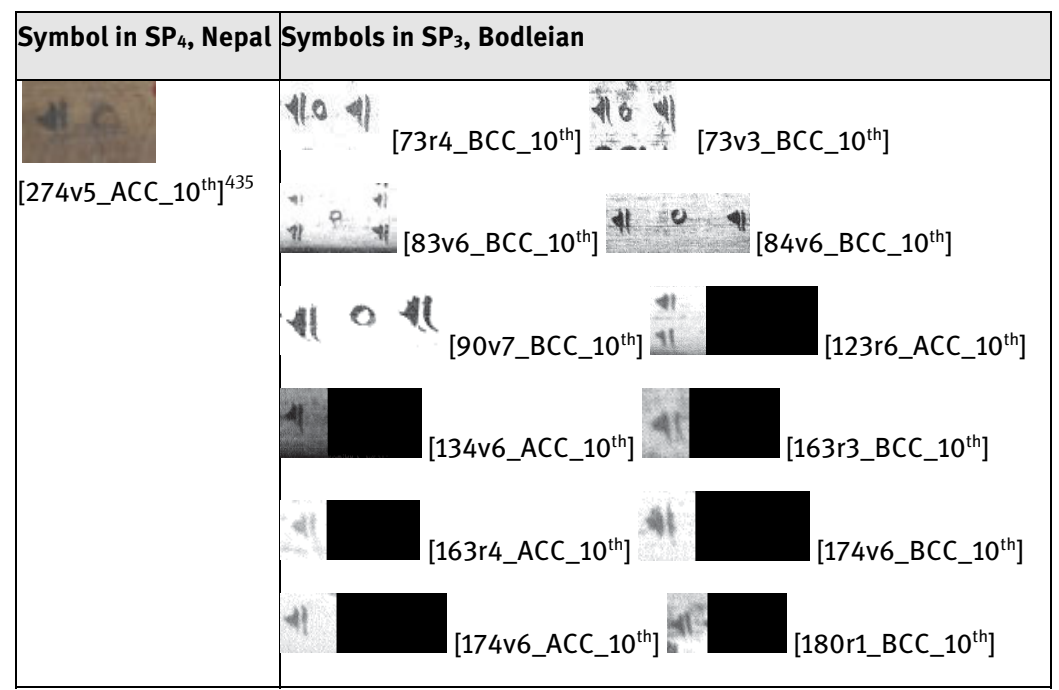

434 See section 3.4, type no. 2 above.

435 This symbol appears right before the right string-hole space and the second set of double dandas appears after the string-hole space. 


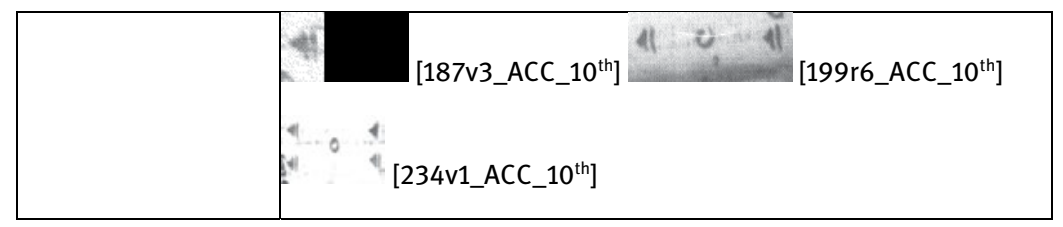

Fig. 3.8.2-VII: Similar symbols in $\mathrm{SP}_{3}$ and $\mathrm{SP}_{4}$

The use of colour could also be helpful in establishing a connection between $\mathrm{SP}_{3}$ and $\mathrm{SP}_{4}$. In the latter, dandas or around the spaces of dandas appearing before and after almost all speaker indications (e.g., sana[tkumāra] u[vāca] 'Sanatkumara said') are highlighted (see also section 5.1 below). As mentioned above, there was only the opportunity to see a few colour images of $\mathrm{SP}_{3}$. The presence of colour can also be seen on dandas or around the spaces of dandas that appear before and after speaker indications (Fig. 3.8.2-IX).

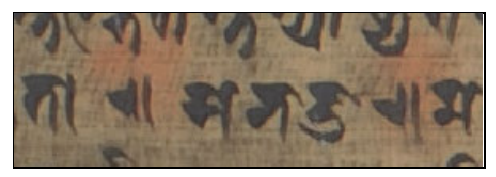

Fig. 3.8.2-VIII: Highlighted dandas or around the spaces of dandas before and after the speaker indication (extracted part from $62 \mathrm{r} 4$ of $\mathrm{SP}_{4}$ )

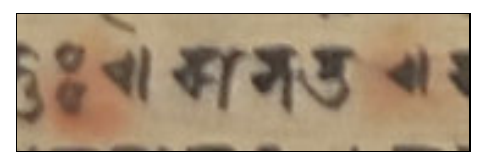

Fig. 3.8.2-IX: Highlighted dandas or around the spaces of dandas before and after the speaker indication (extracted part from $48 \mathrm{r} 3$ of $\mathrm{SP}_{3}$ )

A few identical or near identical symbols appearing at the end of the chapters in $\mathrm{SP}_{3}$ and $\mathrm{SP}_{4}$ have already been seen. Most of the dandas that appear at the end of ślokas or that enclose symbols are identical in both manuscripts. In addition, one can also see a similar use of colour on certain dandas or spaces around the dandas. Alongside other evidence, this example shows how symbols and other visual features can be used to reconstruct dismembered parts of a manuscript. 


\subsection{Symbols and other features as a means to identify a change of scribe}

If more than one scribe were involved in the course of the production of a manuscript, symbols and other features (such as palaeographical evidence, space-fillers and the overall layout of the page) may be helpful in determining the number of scribes involved on that particular manuscript. In the following, a few selected examples taken from five manuscripts of my corpus will be presented to demonstrate how such features can help identify differing scribal hands in one manuscript.

\subsubsection{Symbols and other features in $\mathrm{SP}_{1}$}

As already mentioned in the previous chapter, manuscript $\mathrm{SP}_{1}$ is kept in the NAK under MS no. 2/229 and has been photographed by the NGMPP on reel no. B 11/4. The manuscript is damaged in many parts and most of the foliation has not been preserved (with a few exceptions). Bhaț̣arāī (1988) has used it with siglum 'kha' in his edition and Adriaensen et al. (1998) with siglum 'SP'.

In the considerably disordered folios of $\mathrm{SP}_{1}$, one finds a few folios on the recension of the Pārameśvara(tantra) and a few folios of $\mathrm{SP}_{1}$ bear near similar handwriting to the folios of the recension of the Pārameśvara(tantra). Here I limit myself to the majority of the folios that contain the copy of the Skandapurāna which were 'probably' copied by two different scribes. This is evidenced by noticeable differences in the symbols, palaeographical features and the overall layout. Hereafter, the two scribes are labelled A and B.

Both A and B scribes draw symbols at the end of the chapters and place them between double dandas. Scribe A draws only double circles aside from three small and stylised simple puṣpikās. These three stylised pusppikās contain a circle or dot surrounded by four almost semi-circular petals and four lines (see the first column in Fig. 3.9.1-I). Conversely, scribe B draws a large variety of beautiful symbols (see the second column in Fig. 3.9.1-I). Furthermore, clear differences are to be seen in the double dandas written by scribe A or B (see below). 


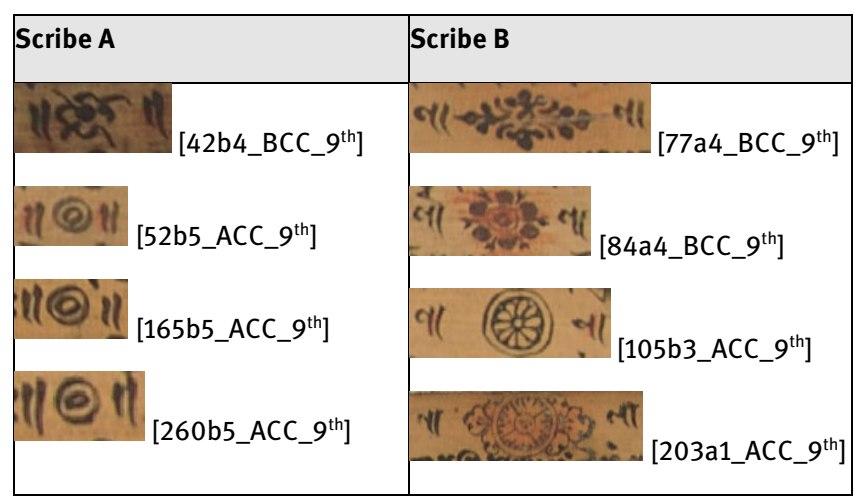

Fig. 3.9.1-I: Symbols by scribes A and B

Both scribes write dandas before and after the chapter colophons or around their symbols. Scribe A, however rarely uses double dandas to demarcate verses, or before and after speaker indications. ${ }^{436}$ Instead, he uses single dandas that are more or less straight (see the first row in the first column in Fig. 3.9.1-II), where the first of the two dandas are shorter than the second one (see the first column in the second row in Fig. 3.9.1-II). On the other hand, scribe B's single dandas written in various places within the manuscript are slightly curved or slanted (see the second column in the first row in Fig. 3.9.1-II). Scribe B writes double dandas at the end of ślokas that differ to those of scribe A writes before and after chapter colophons. As stated in the previous chapter, the first of the two dandas has a hook-like component added horizontally at its centre (see the second column in the second row in Fig. 3.9.1-II). It is also important to note that scribe A's dandas are slightly thicker than scribe B's dandas.

436 A portion of the transcription of the text from (131a4): pitara uvāca | tatas te suraśārdūlāh $|\odot|$ prapracchaḥ svāṃ sutāṃ tadā | prāyaścittāni dharmāñ ca vedāṃ sāṃgām savistarāṃ | te ca tebhyas tadā putrā $|\odot| \bar{a} c a k s ̦ u h$ prayatā subhāḥ $\mid$... 


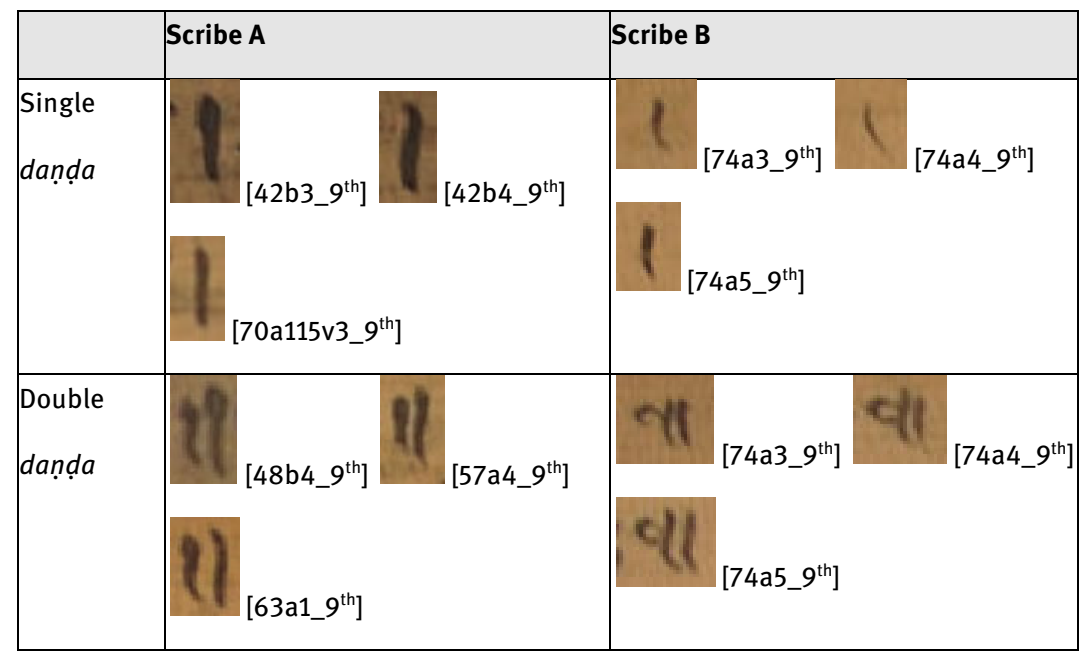

Fig. 3.9.1-II: Single and double daṇa tas by scribes A and B

Differences appear in the way scribe A and B write akșaras. Here are two examples of each of the selected akșaras, namely $k a, g a$, tha and $h \bar{a}$ (see Fig. 3.9.1-III).

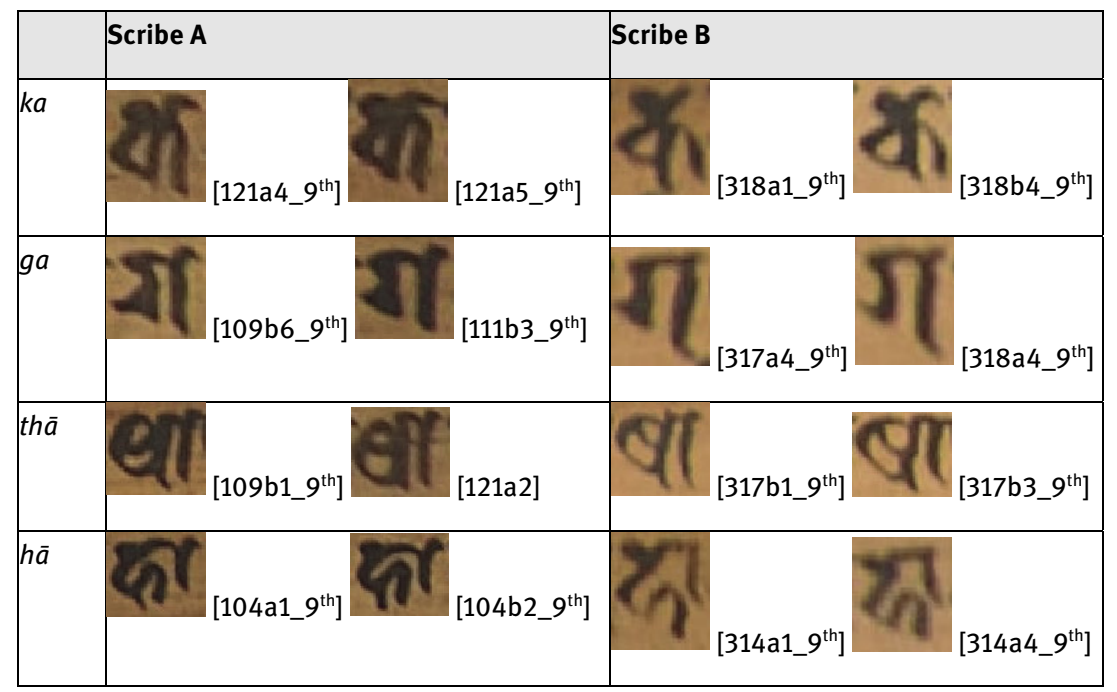

Fig. 3.9.1-III: Akșaras by scribes A and B 
Space-fillers also indicate the work of at least two different scribes. Scribe A draws space-fillers with a hooked head followed by a more or less straight line. Space-fillers are always drawn from left to right (see the first column in Fig. 3.9.1-IV). Scribe B also draws space-fillers with a hooked head, but the following 'tail' is rather wavy at first and then becomes straight. The direction scribe B draws the filler is both left to right and right to left (see the second column in Fig. 3.9.1-IV).

\begin{tabular}{|c|c|}
\hline Scribe A & Scribe B \\
\hline$\left[11 \mathrm{~b} 79^{\mathrm{th}}\right]$ & [80b116r6_9 $\left.9^{\text {th }}\right]$ \\
\hline [165a78r7_9 $\left.9^{\text {th }}\right]$ & [78a193v6_9 $\left.9^{\text {th }}\right]$ \\
\hline
\end{tabular}

Fig. 3.9.1-IV: Space-fillers by scribes A and B

In addition to the different symbols and palaeographical evidence that reveal information on the number of scribes involved in the production of $\mathrm{SP}_{1}$, elements of the overall layout should also be taken into consideration. There are two string-holes on each folio and the text has been divided into three textsections. Scribe A writes most of the text without any further division. This means there are no clear gaps between the first and second half of the śloka (see Fig. 3.9.1-V). However, scribe B divides the ślokas by leaving gaps between their first and second halves on many folios (see Fig. 3.9.1-VI). ${ }^{437}$

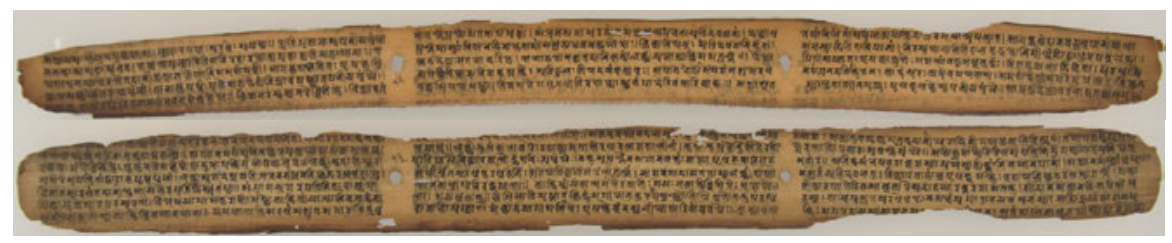

Fig. 3.9.1-V: Overall layout by scribe A (61ab) @ NAK

437 I discuss the use of gaps and layout features further in section 4.2.2.1 below. 


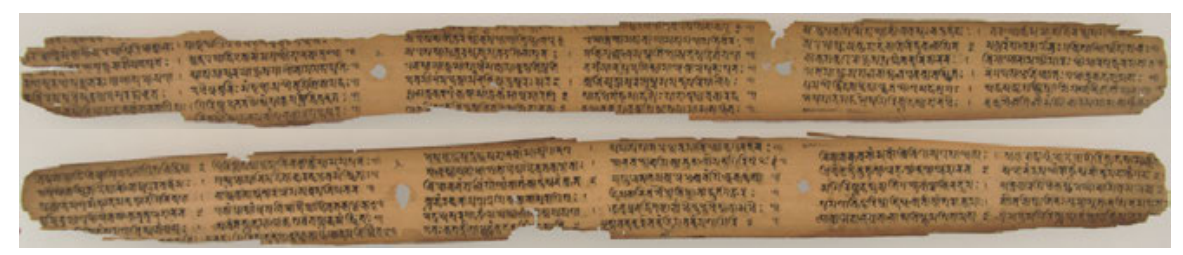

Fig. 3.9.1-VI: Overall layout by scribe B (74ab) @ NAK

This significantly large amount of evidence clearly indicates that at least two scribes have been involved in the production of $\mathrm{SP}_{10}{ }^{438}$

\subsubsection{Symbols and other features in $\mathrm{SP}_{2}$}

Features in another manuscript of the Skandapurāna tells of the involvement of at least two scribes in its production. This manuscript has been kept in the NAK, under the MS no. 1/831 and has been photographed by the NGMPP on reel B 12/3 (and retaken as A 1086/2?). This manuscript was designated by Bhațtarāi (1988) with siglum ' $k a$ ' and by Adriaensen et al. (1998) with ' $\mathrm{SP}_{2}$ ' in their editions. Here it is referred to as $\mathrm{SP}_{2}$.

From the appearance of the symbols at the end of the chapters and other palaeographic and layout-related evidence, it is safe to assume there were at least two scribes involved in the manuscript production. ${ }^{439}$ Here, are presented several selected symbols, dandas, akșaras, space-fillers and layout features that are possible to be attributed to one or the other of the two scribes. The two scribes are dubbed A and B.

Scribes A and B both draw symbols at the end of chapters. Scribe A draws a variety of symbols from simple double circles to two realistic puspikās ${ }^{440}$ (see left column in Fig. 3.9.2-I). It should be noted that most of his symbols appear after chapter colophons. At times he leaves blank spaces at the end of chapters, where one would expect symbols. His symbols vary enormously in shape, size and artistic value. Their height is of one to three lines of the folio. Whereas, scribe B draws only simple double circles encompassing only one line of the folio (see the right column in Fig. 3.9.2-I).

\footnotetext{
438 Only if we exclude the other hand that appears similar to the handwriting of PT etc.

439 Save for one folio on which a content list with numbers arranged in columns placed between vertical lines. Most of these numbers have no writing accompanying them. But a few of these numbers contain 'titles' from a few chapters. It is likely the numbers unaccompanied by writing were to be filled by 'chapter titles'. However, the handwriting of these items looks modern by comparison with the hands of the text of other folios.
}

440 Both realistic pușpikās have been discussed in section 3.5.1 above. See also Fig. 3.5.1-I. 


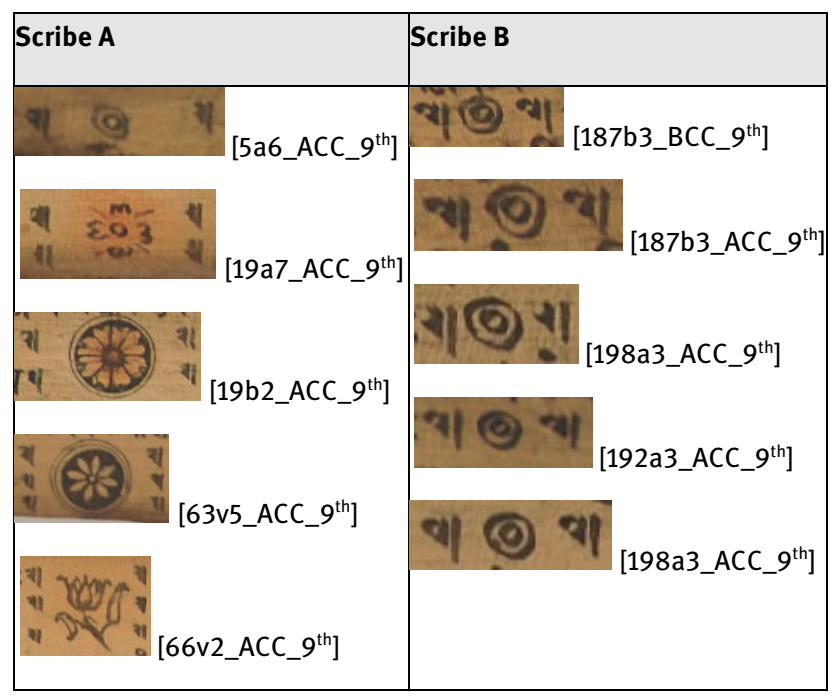

Fig. 3.9.2-I: Symbols by scribes A and B

Regarding the dandas, A writes two types of single dandas; his first type of single daṇa is slanted and the second type more or less straight but with a hooklike element added horizontally to its centre (see the left column in the first row in Fig. 3.9.2-II), but scribe B's, single dandas are predominantly straight (see the right column in the first row in Fig. 3.9.2-II).

Both scribes use double dandas. A uses at least two types of double dandas. A's first danda of the first double dandas includes a hook-like element at its near centre; and the line at the top curves to the left. However, the first danda of his second type of double dandas only features a hook-like element.

$\mathrm{B}$ draws at least three types of double dandas. The first danda of his first type of double dandas has no additional element and is slightly shorter than the second (see the left column in the second row in Fig. 3.9.2-II). This type of double daṇas often appear after the second half of the ślokas.

The first danda of his second type of double dandas contains only a hooklike element (see the right column in the third row in Fig. 3.9.2-II), however, the first danda of his third type of double dandas has a remarkable curved line on its upper side (see the right column in the fourth row in Fig. 3.9.2-II). The left part looks significantly thicker. Both types of double dandas appear before and after the symbols at the end of the chapters. 


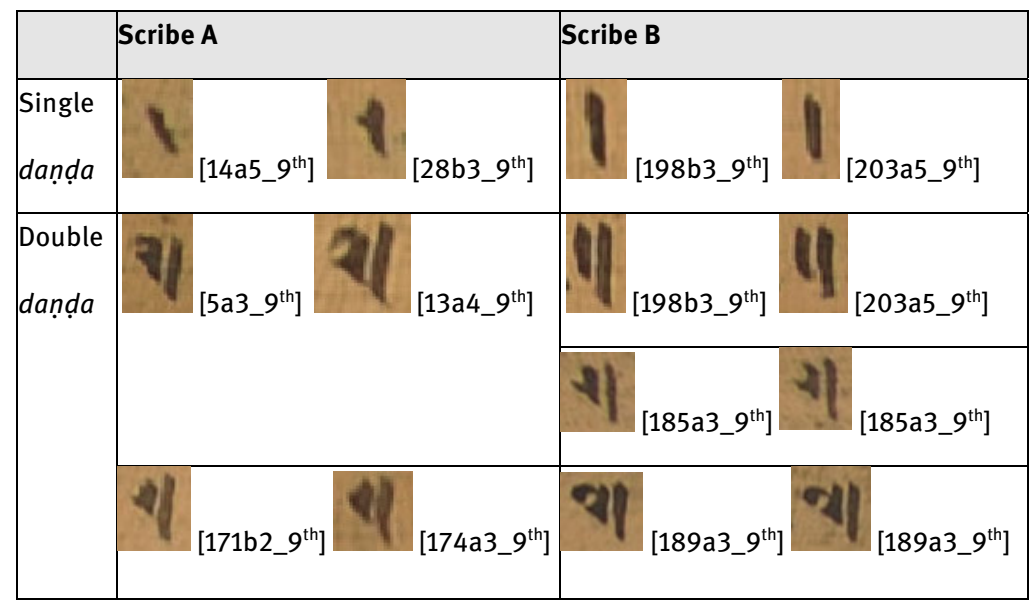

Fig. 3.9.2-II: Single and double dandas by scribe A and B

Differences can also be seen in the way the akșaras are written. I have gathered some selected akșaras here, namely $a$ and $k a$. Upon close examination, it is barely possible to make out whether A or B wrote them (see Fig. 3.9.2-III).

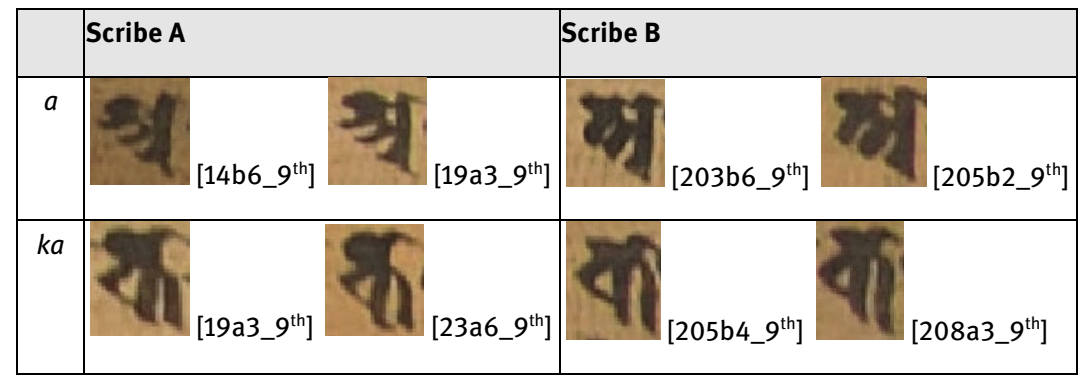

Fig. 3.9.2-III: Akșaras by scribes $\mathrm{A}$ and $\mathrm{B}$

Space-fillers provided other important evidence. Scribe A's space-fillers look like a tight coil with a slanted 'tail'. The head of the space-fillers is often bent down (see the left column in Fig. 3.9.2-IV below). However, most of scribe B's space-fillers look like a kind of stretched coil followed by a nearly straight 'tail' (see the lower three examples in right column). Their heads are on both the upper and lower sides (see the right column in Fig. 3.9.2-IV). 


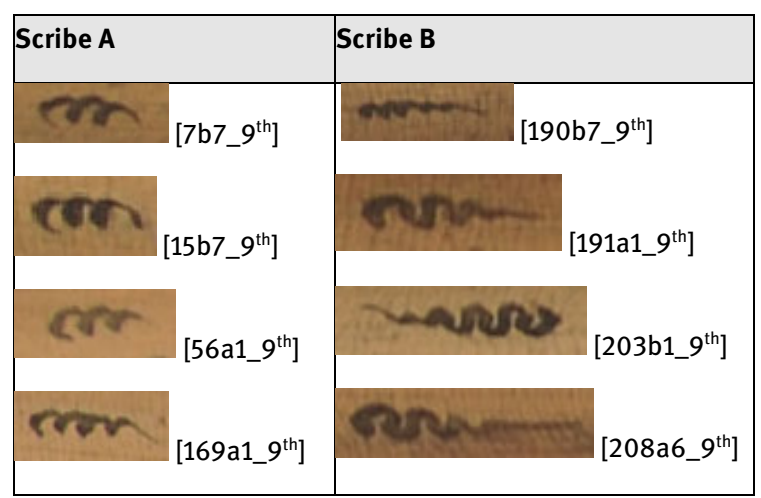

Fig. 3.9.2-IV: Space-fillers by scribes A and B

In terms of layout is concerned, there are two string-holes on each folio and the text has been divided into three text-sections. On many folios scribe A uses small gaps between the first and second half of the ślokas (see the lower folio in Fig. 3.9.2-V). On at least one folio such small gaps are justified in text-sections (see the upper folio in Fig. 3.9.2-V). Scribe B often writes the text in a dense way without clear, visible gaps between the first and second halves of ślokas or lines (see in Fig. 3.9.2-VI). ${ }^{441}$

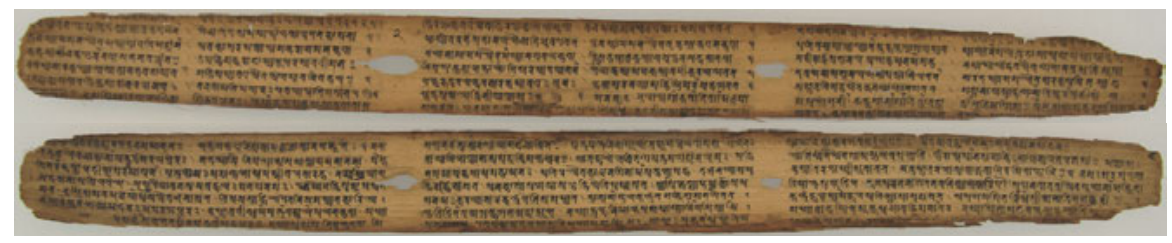

Fig. 3.9.2-V: Overall layout by scribe A, fols.(?) (5ab) @ NAK

441 I discuss the use of gaps and layout features of this manuscript further in section 4.2.2.2 below. 


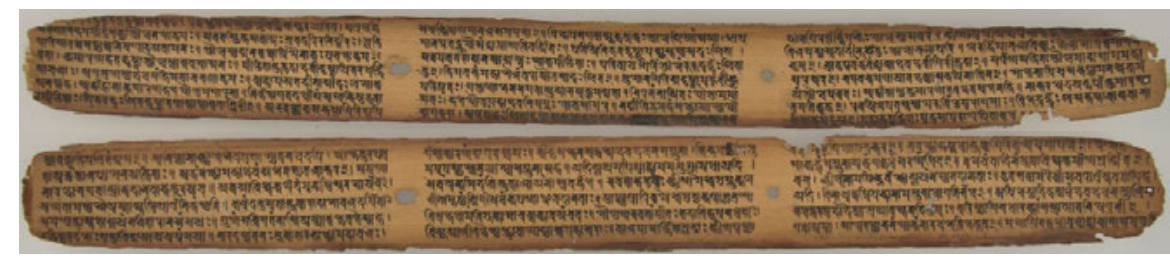

Fig. 3.9.2-VI: Overall layout by scribe B, fols.(?) (205ab) @ NAK

Based on the differences in the characteristics of the symbols, dandas, akșaras, space-fillers, the overall layout and how they are written and designed, it is safe to assume at least two scribes, working on the manuscript production either together or one after the other.

\subsubsection{Symbols and other features in KT}

Another relevant example is the manuscript copy of the Kiranatantra. The manuscript is kept in the NAK under NAK no. 5/893 and has been microfilmed by the NGMPP on reel A 40/3. The manuscript contains an important saiva trantric text. Goodall (1998) used the manuscript in his edition with the siglum ' $\mathrm{N}_{1}$. ${ }^{442}$ Here I call it KT.

Apart from a portion of the text (a part of the second line and third and fourth lines) on the folio 99r and the last two folios there is a table of contents of probably added later. Here it can be assumed there were at least three scribes involved in the manuscript production. The three scribes are denoted as A, B and C.

All three scribes draw symbols at the end of chapters. Scribe A largely draws symbols containing circles surrounded by four petals and four lines. He also draws a few double circles (see left column in Fig. 3.9.3-I).

Scribe B also draws symbols at the end of chapters. But his symbols have different stylised pușpikās, double circles and some puzzling symbols (see the middle column in Fig. 3.9.3-I). ${ }^{443}$ Please note that some of his symbols appear to have been drawn over previously made symbols. In symbol on 50r4, four lines of the previous symbol remain visible.

442 See Goodall 1998, lxxxiv-lxxxv.

443 I have discussed this manuscript and some of its features in section 3.6.2.2 and 3.6.2.4.1 above. 
Scribe $\mathrm{C}$ also draws symbols at the end of chapters. However, he usually draws stylised puspikās consisting of a circle surrounded by four petals and four lines. Each petal of the symbol appears to have been made by joining two almost semi-circular elements on the side. He also draws several circles, one with a curved line at its centre, one with a curved line surrounded by a circle and a double circle (see right column in Fig. 3.9.3-I below). Compared to the symbols of scribe A and B, his are quite different in shape. One can also see a few differences between the dandas of scribe A, B and C demarcating the symbols.

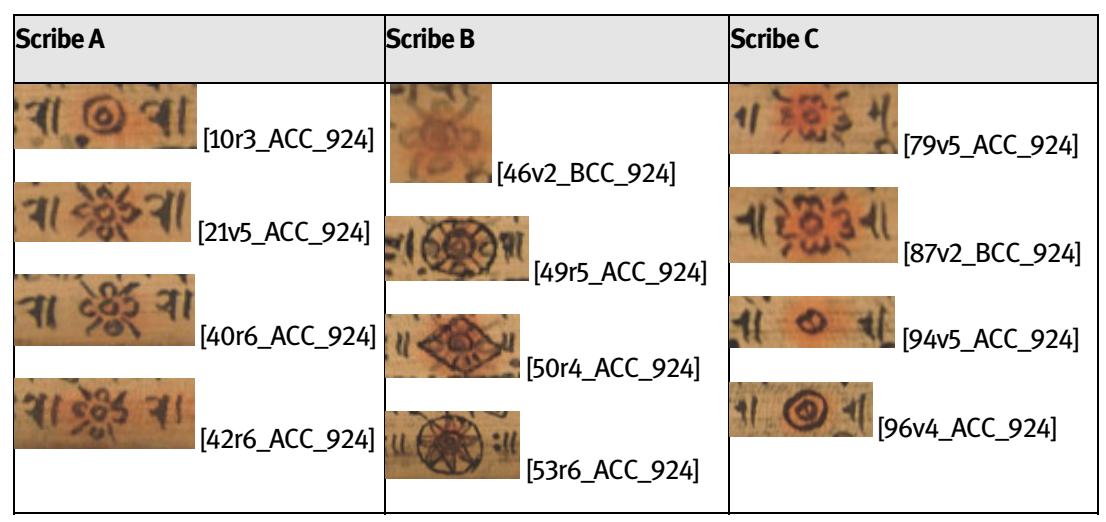

Fig. 3.9.3-1: Symbols by scribes A, B and C

The manner in which the akșaras are written also differs significantly. The following figure shows the differences characterising some selected akșaras (i.e. $i$, ṇa and $m a)$.

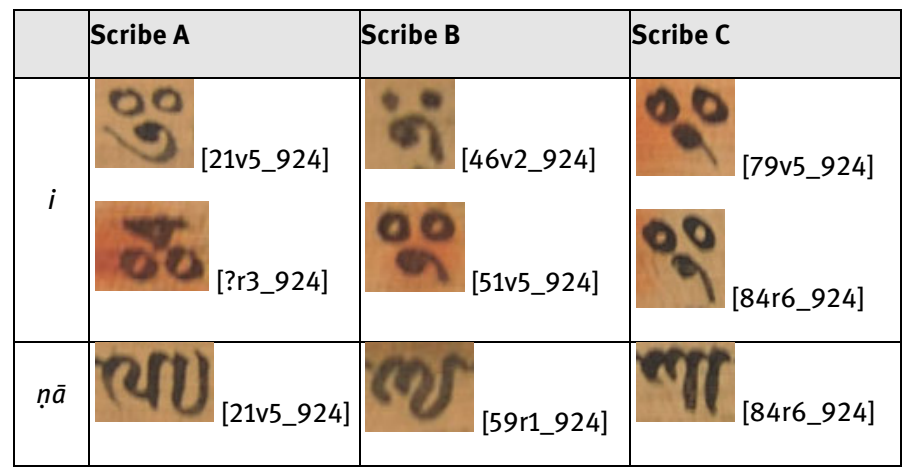




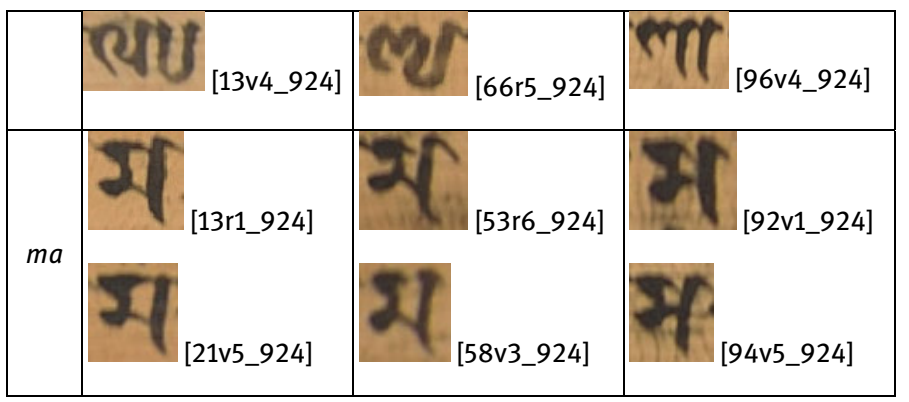

Fig. 3.9.3-II: Akșaras by scribes A, B and C

Regarding the space-fillers, the wavy lines drawn by scribe A are far denser than those of scribe B and C (see the left column in Fig. 3.9.3-III). The front part of space-fillers of B always starts from the right (see the middle column in Fig. 3.9.3-III). The beginning part of C's space-fillers commences with a hooked head, followed sometimes by a short wavy line ending in a more or less straight line (see the right column in Fig. 3.9.3-III).

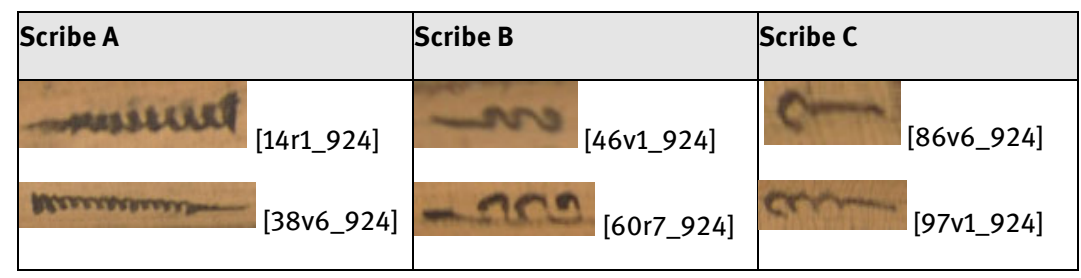

Fig. 3.9.3-III: Space-fillers by scribes A, B and C

In terms of layout, there are two string-holes on each folio. Scribe A divides the text into three text-sections determined by the string-holes. However, scribe $B$ and $\mathrm{C}$ divide the text into two text-sections only. Compared with scribes $\mathrm{B}$ and C, scribe A's handwriting is more attractive and the akșaras appear slightly larger (see Figs. 3.9.3-IV and 3.9.3-VI). Furthermore, scribe A has left generous free spaces on the left and right margins and the text has been more carefully arranged than those on the folios of scribes B and C. 


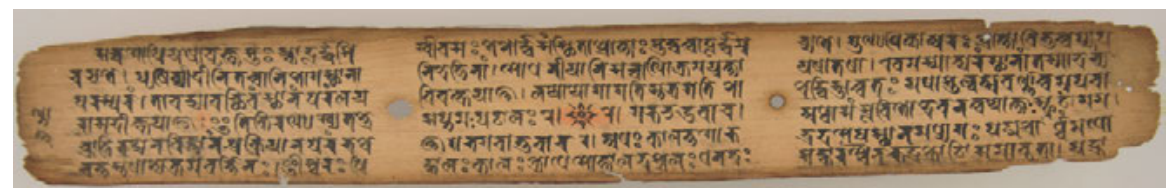

Fig. 3.9.3-IV: Overall layout by scribe A, fol. $13 v$ @ NAK

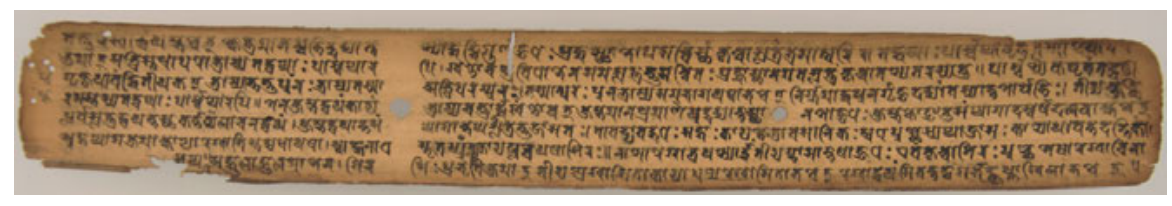

Fig. 3.9.3-V: Overall layout by scribe B, fol. 44v @ NAK

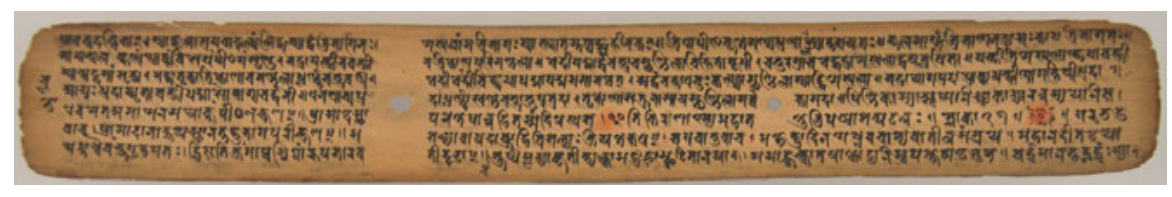

Fig. 3.9.3-VI: Overall layout by scribe C, fol. 79v @ NAK

Such clear differences in the drawing of the symbols, writing the akșaras, making space-fillers and the overall layout make it safe to assume that at least three scribes have worked on the manuscript production.

\subsubsection{Symbols and other features in TSPV}

Here attention is turned to manuscript TSPV which is in possession of Jinabhadrasūri Grantha Bhanḍāra, Jaisalmer under MS no. 378 and dated ca. 1143 c. ${ }^{444}$

The analysis of symbols, space-fillers and overall layout suggest that at least four scribes have been involved in the production of the manuscript. Here, identified as scribes A, B, C and D.

With the exception of scribe $\mathrm{C}$, all scribes draw symbols around the stringholes. These symbols present clear differences. Scribe A's symbols appear to be

444 See Jambuvijay 2000, 40. 
comprised of largely strokes or lines (see the left column in Fig. 3.9.4-I). Compared to B and D; A's symbols are less sophisticated.

Scribe B's symbols contain four almost semi-circular petals. One line seems to have been added horizontally to the upper part of the semi-circular petal. A 'tail' has been added to the lower part of the lower semi-circular petal and the 'tail' hangs downward to the right (see second column from left in Fig. 3.9.4-I).

D's symbols are slightly similar to those of B. One horizontal line is added to the upper element of the symbol and a tail to its lower part. However, the left and right elements of D's symbols are clearly differently drawn to those of both A and B. The petals are made by joining two semi-circular elements on the side (see right column in Fig. 3.9.4-I). As the examples show, parts of D's symbols are frequently missing due by the part of the folio around the string-holes being missing.

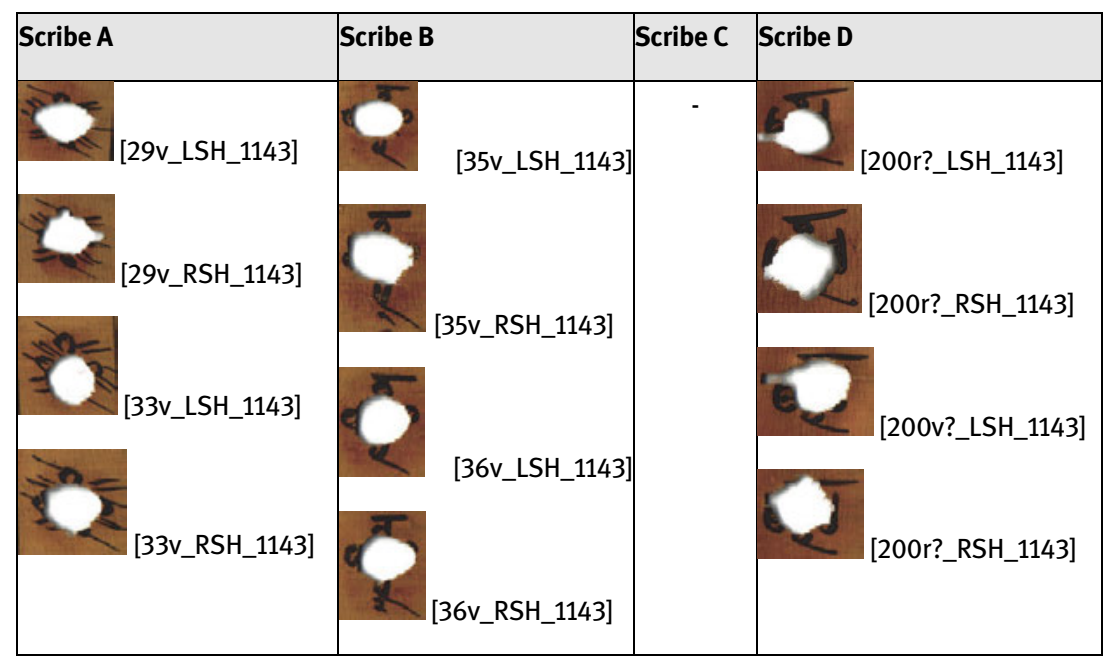

Fig. 3.9.4-I: Symbols by scribes A, B and D

Scribes A, B, C and D all use space-fillers, but of different shapes. Scribe A draws semi-circle-like space-fillers with the upper left part bending inward and touching the inner part. The upper right part, however, is simply bent inwards (see the left column in Fig. 3.9.4-II). B largely draws coil-like space-fillers followed by a slanted line (see the second column from the left in Fig. 3.9.4-II). With a few exceptions C usually draws two types of space-fillers. The first type has a hooked head followed by a slanted line. The second looks like a semi-circle with its upper left 
and right lines bent inwards (see the third column from the left in Fig. 3.9.4-II). Notably, the second type seems to be a variation of the letter-numeral ' 80 '. ${ }^{445}$

Space-fillers of D are almost similar to the second type of space-fillers written by $\mathrm{C}$, but their upper right part is followed by a sort of tail (see right column in Fig. 3.9.4-II).

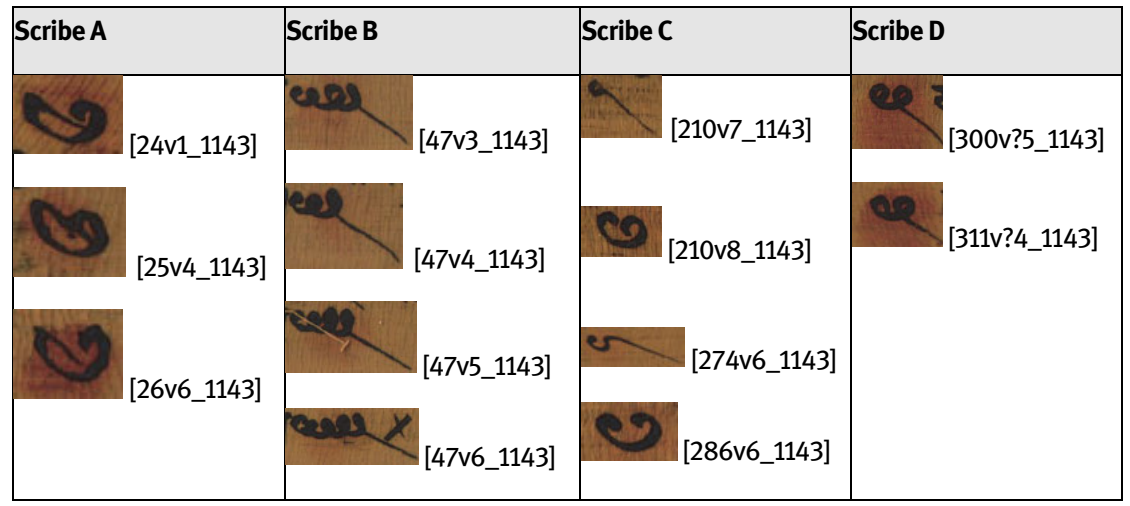

Fig. 3.9.4-II: Space-fillers by scribes A, B, C and D

Differences can also be seen all the four scribes' overall layout. There are two string-holes on each folio and the text is divided into three text-sections. All scribes use ruling-lines except for $\mathrm{C}$.

A's ruling-lines consist of sets of parallel vertical lines, which demarcate each text-section on the folio (see Fig. 3.9.4-III). A clear gap can be seen between those vertical lines. Scribes B and D largely use a set of two parallel vertical lines. Scribes A, B and D write the text more or less in straight lines and their handwriting is tidy. However, C's handwriting is less neat to that of A, B and D and the lines are often not particularly straight.

445 See Bendall 1883, Table of Letter-numerals; Kapadia 1936, Plate II, VI. 


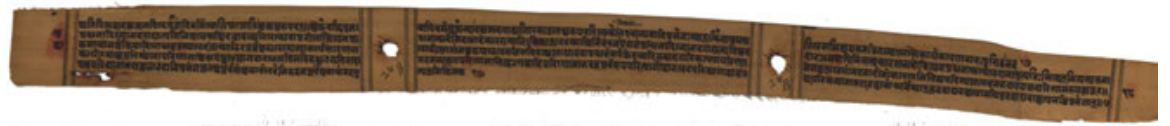

Fig. 3.9.4-III: Overall layout by scribe A, fol. 18v @ Jinabhadrasūri Grantha Bhạ̣ḍāra, Jaisalmer

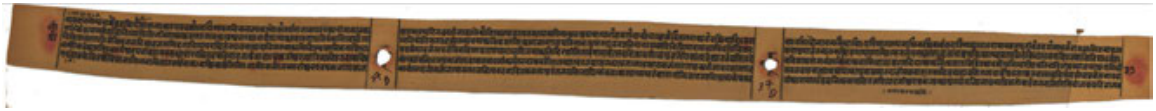

Fig. 3.9.4-IV: Overall layout by scribe B, fol. 37v @-Jinabhadrasūri Grantha Bhaṇḍāra, Jaisalmer

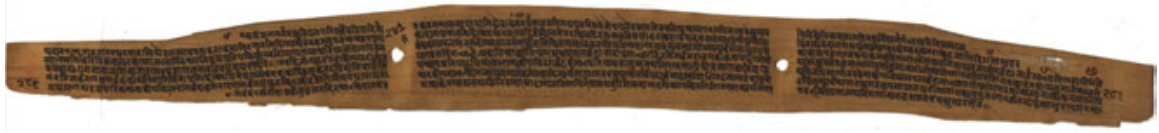

Fig. 3.9.4-V: Overall layout by scribe C, fol. 281v/286v? @ Jinabhadrasūri Grantha Bhaṇḍāra, Jaisalmer

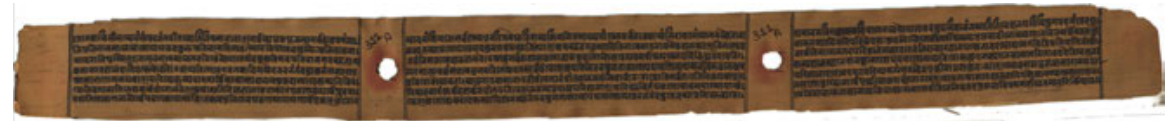

Fig. 3.9.4-VI: Overall layout by scribe A, fol. 312v @ @ ( Jinabhadrasūri Grantha Bhaṇḍāra, Jaisalmer

\subsubsection{Symbols and other features in TUS}

The last example in this section is the manuscript kept in the Sanghavina pādāno bhanḍāra under MS no. 168 (2) and dated VS 1349 (corresponding to ca. 1292 CE). The manuscript was used by Sanghavi and Rasiklal (1987) in their edition. The manuscript contains an important text of the Lokāyata tradition.

Aside from 'cha' symbols, stylised pușpikās can be found around the stringholes on the folio. From the appearance of the symbols and the overall layout, we may assume at least two scribes were involved in the manuscript production. To demonstrate this a few observations on selected symbols around the string-holes and on the overall layout will be presented. The scribes are referred to as A and B. 
Both A and B draw symbols around string-holes. A often makes symbols containing four almost semi-circular petals and four lines (see the left column in Fig. 3.9.5-I). ${ }^{446}$ B's symbols also contain four almost semi-circular petals; however, they do not contain the four lines. Their lower petal is followed by a 'tail' added to its lower part. This tail frequently runs downward to the right (see right column in Fig. 3.9.5-I).

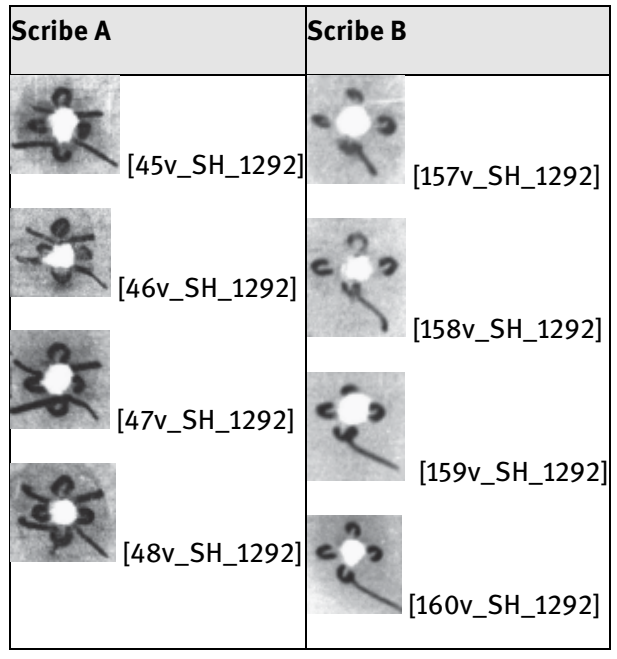

Fig. 3.9.5-I: Symbols by scribes A and B

Regarding the manuscript layout, both scribes write the text in two text-sections with each text-section demarcated by vertical ruling-lines. Some gaps between the text-lines can be seen on the folios written by B (see in Fig. 3.9.5-III), but the same gaps are not as clearly visible on A's folios (see in Fig. 3.9.5-II). The size of A's characters is bigger than those of B's characters. B's writing is more attractive and regular than that of $\mathrm{A}$.

446 Most of the symbols found around string-holes in the manuscript of the Savaga Padikkamana Sutta cunni (Śrāvakapratikramasūtra-cūrṇi) (VS 1317 / 1260 CE) (Museum of Fine Arts, Boston. Denman Waldo Ross Collection, 30.1.1-229) appear to some extent like this type. 


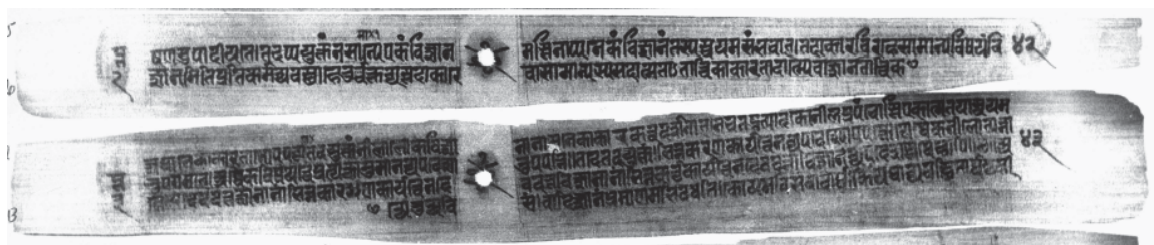

Fig. 3.9.5-II: Overall layout by scribe A, fols. 42v, 43v @ Hemacandrācārya Jaina Jñānamandir, Patan

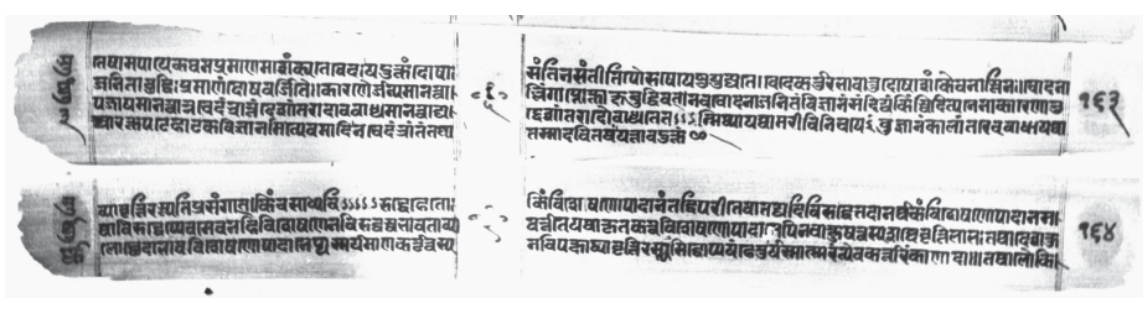

Fig. 3.9.5-IIl: Overall layout by scribe B, fols. 163v, 164v ㄷ Hemacandrācārya Jaina Jñānamandir, Patan

\subsubsection{Symbols and other features as means to identify a change of scribes - Preliminary conclusions}

In Nepalese manuscripts $\mathrm{SP}_{1}, \mathrm{SP}_{2}$ (ca. $9^{\text {th }}$ c.) and $\mathrm{KT}$ (924 CE) remarkable changes in terms of symbols, space-fillers, akșaras, and the overall layout, occur, the instant there is a change of scribe. In the $12^{\text {th }} \mathrm{c}$. West Indian manuscript TSPV and the $13^{\text {th }}$ c. manuscript TUS, there is clear evidence of changes affecting symbols drawn around string-holes. Alongside other features these examples show that (e.g. palaeographical and layout related ones), symbols serve as one of the essential components enabling us to understand if a manuscript has been copied by more than one scribe and whether the symbols have been drawn by the scribes themselves. 


\subsection{Some preliminary conclusions on use of symbols}

In my corpus symbols can be found in almost all manuscripts from all areas. On the whole, symbols serve both to structure the texts and decorate the manuscript.

In terms of the regional occurrence and distribution of symbols, in most of the manuscripts of the three areas under scrutiny here, they often appear at the end of chapters or whole texts. However, stylised pușpikās often appear around stringholes or together with folio numbers in manuscripts from Western India. Only occasionally, in a few Nepalese manuscripts, is the same practice observed and their occurrence is not even consistent within the same manuscript.

Compared to manuscripts from East and West India, Nepalese manuscripts are characterised by an extremely large variety of symbols. Their size varies to a large extent, ranging from an area of one line to the almost the whole height of the folio's written area. The aesthetic value of Nepalese symbols is noteworthy compared with the symbols used in the manuscripts from the other two areas here under investigation. In manuscripts from Nepal we find symbols drawn in a vivid and realistic style, representing real flowers with petals, stalks and leaves (see section 3.5.1). It may be noted that changes in size or quality of symbols in the same manuscript may serve to represent the hierarchical levels of the text.

A variety of symbols are to be found in East Indian manuscripts. They are largely at the end of chapters or whole texts and appear in different shape and size. Conversely, West Indian manuscripts comprise a smaller variety of symbols. Their size is small, usually occupying one text line of the folio. An important custom for this region is for all manuscripts (with but a few exceptions) to include symbols around the string-holes. The available data suggests the drawing of stylised pușpika with four petals, with or without four lines or similar features could well have been a widespread convention for manuscripts produced in this area. Only manuscripts from West India, feature small symbols like stylised pușpikās appearing every ten pages together with the folio number on the left margin.

As already mentioned in section 3.6.2.1, some symbols may be drawn in a manner reflecting the religious and ritualistic aspects of the text or the whole manuscript in which they are found e.g. the series of three symbols on the folio at the end or the final conclusion of Buddhist manuscripts (see section 3.6.2.2.3).

Combined with several other features (such as palaeographical peculiarities, layout, etc.), symbols can also help understand whether more than one scribe was involved in the production of a specific manuscript (see section 3.9). Likewise, symbols may to some extent help with the possible dating of hitherto undated manuscripts and reassemble different parts of a currently dismembered manuscript (see section 3.8). 